DANIEL GAMA E COLOMBO

\title{
A POLÍTICA PÚBLICA DE INCENTIVO AO SETOR DE INFORMÁTICA NO BRASIL A PARTIR DA DÉCADA DE 90: uma análise jurídica
}

Dissertação apresentada à Faculdade de Direito da Universidade de São Paulo, sob orientação do Professor Diogo Rosenthal Coutinho, para obtenção do título de Mestre em Direito Econômico

FACULDADE DE DIREITO DA UNIVERSIDADE DE SÃO PAULO

$$
\text { SÃO PAULO }
$$


Para a elaboração desta dissertação o pesquisador contou com uma Bolsa de Mestrado concedida pela Fundação de Amparo à Pesquisa do Estado de São Paulo - FAPESP, conforme processo 06/01928-3. 


\section{AGRADECIMENTOS}

Agradeço ao Professor Dr. Diogo Rosenthal Coutinho pela oportunidade, confiança, orientação e, principalmente, pelo enriquecedor convívio profissional ao longo dos anos de elaboração desta dissertação.

Aos Professores Hélio Cruz e Renato Garcia, não apenas pelas recomendações e conselhos em minha Banca de Qualificação, mas por todo o ensinamento e diálogo.

Aos membros do grupo de pesquisa da FDUSP coordenado pelos Professores Virgílio Afonso da Silva e Diogo Rosenthal Coutinho e do grupo de Políticas Públicas da FDUSP coordenado pelos Professores Diogo Rosenthal Coutinho e Ana Maria Nusdeo, assim como aos pesquisadores e profissionais do GVLaw (da Escola de Direito de São Paulo da Fundação Getulio Vargas), todos excelentes profissionais que me ensinaram bastante sobre pesquisa acadêmica comprometida em direito.

Aos colegas e profissionais de Pinheiro Neto - Advogados, por terem me apresentado ao setor de informática e aguçado minha curiosidade acerca desta fascinante indústria.

Aos meus pais, irmãos e família, por tudo, mas em especial pelo apoio incondicional em minha decisão de realizar este projeto, sem o qual ele não teria sido viável.

A todos os amigos e colegas que, direta ou indiretamente, me apoiaram ou participaram da elaboração deste trabalho.

Por fim, aproveito a oportunidade para prestar minha homenagem à Família Ferreira Silva e ao Sr. Toraichi Haguihara. Agradeço por tudo o que fizeram por mim. 


\section{ÍNDICE ANALÍTICO}

RESUMO

SIGLAS E ABREVIAÇÕES UTILIZADAS ........................................................

CONSIDERAÇÕES INICIAIS .......................................................................................... 10

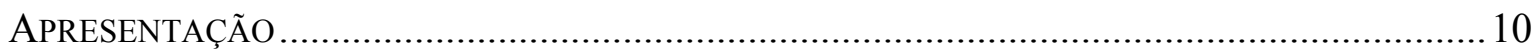

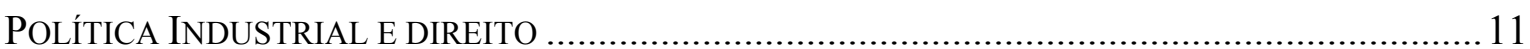

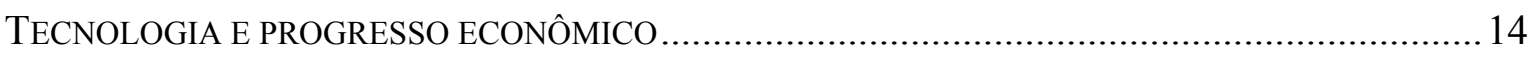

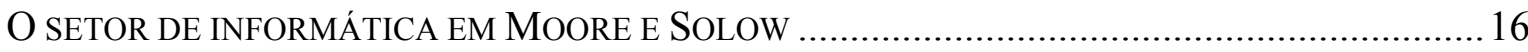

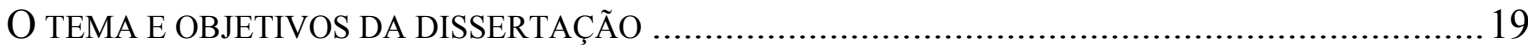

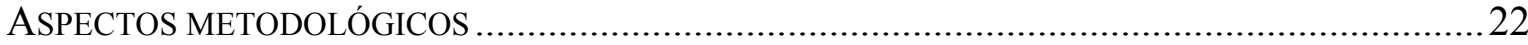

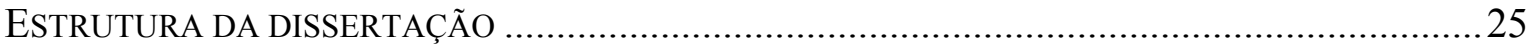

\section{CAPÍTULO 1. O DEBATE TEÓRICO SOBRE POLÍTICA INDUSTRIAL E A}

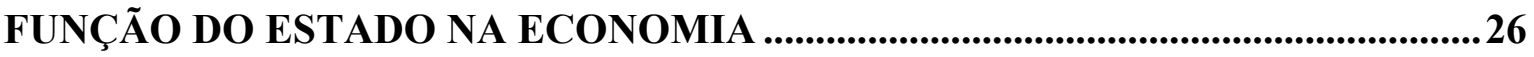

1.1 APRESENTAÇÃO DO DEBATE: TEORIAS DA INTERVENÇÃO DO ESTADO NA ECONOMIA E

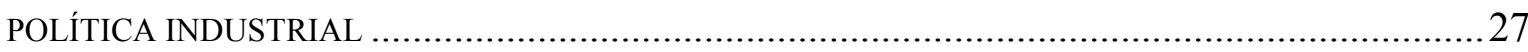

1.2 A ESCOLA NEOCLÁSSICA: POLÍTICA INDUSTRIAL E FALHAS DE MERCADO .........................35

1.3 O NEO-UTILITARISMO E A LITERATURA DE FALHAS DE GOVERNO.................................. 41

1.4 A DEFESA DA POLÍTICA INDUSTRIAL: A ESCOLA EVOLUCIONÁRIA …..................................45

1.5 PRINCIPAIS PONTOS DA ANÁLISE TEÓRICA; IMPORTÂNCIA DA ABORDAGEM EVOLUCIONÁRIA PARA A PESQUISA

CAPÍTULO 2. ENTRE MILITARES E GUERRILHEIROS: A ANTIGA POLÍTICA NACIONAL DE INFORMÁTICA .....................................................................58

2.1 CENÁRIO DA INDÚSTRIA DE INFORMÁTICA NO PLANO EXTERNO....................................59

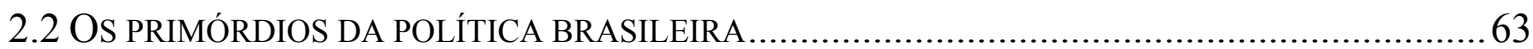

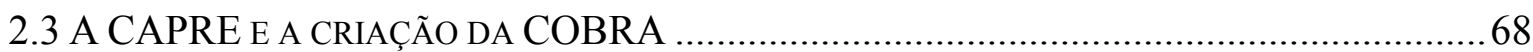

2.4 CHOQUE DO PETRÓLEO E A RESTRIÇÃO ÀS IMPORTAÇÕES ............................................ 71

2.5 RESERVA DE MERCADO E A LICITAÇÃO DOS MINICOMPUTADORES ...................................74

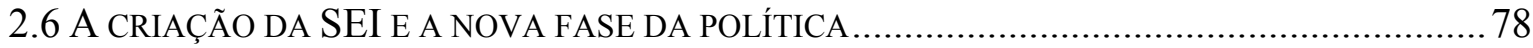


2.7 A ATUAÇÃO INICIAL DA SEI, A LICITAÇÃO DOS SUPERMINIS E A LEI DE INFORMÁTICA ... 82 2.8 PRESSÕES EXTERNAS: A DISPUTA COMERCIAL COM OS ESTADOS UNIDOS SOBRE A

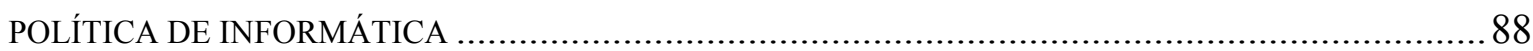

2.9 A SUPERAÇÃO DA ANTIGA POLÍTICA NACIONAL DE INFORMÁTICA ..................................92

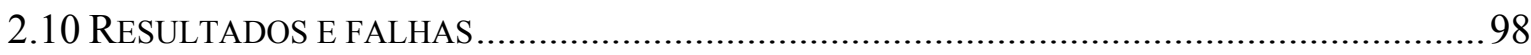

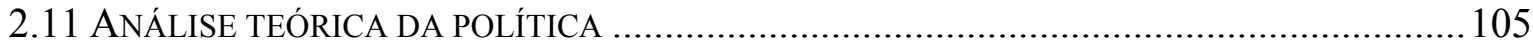

\section{CAPÍTULO 3. A ABERTURA ECONÔMICA E A NOVA POLÍTICA DE}

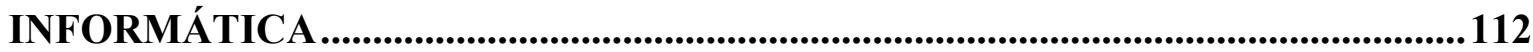

3.1 O GOVERno COLlor DE MELlo E A NOVA ORIENTAÇÃO ECONÔMICA ........................... 113

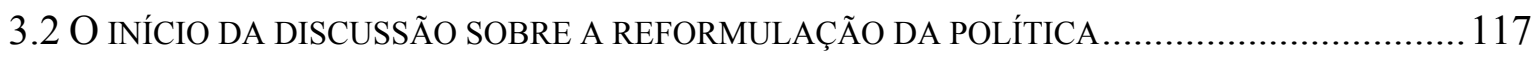

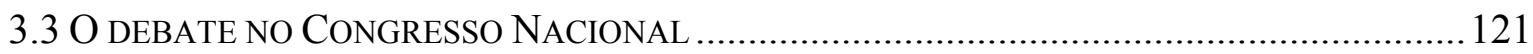

3.4 PRINCIPAIS NORMAS E REGRAS; OS PRIMEIROS ANOS DA NOVA LEI DE INFORMÁTICA ... 129

3.5 O FIM DA EMPRESA BRASILEIRA DE CAPITAL NACIONAL .................................................. 134

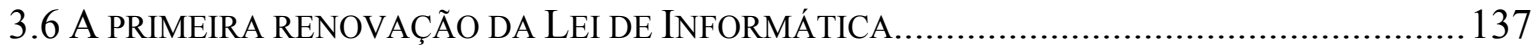

3.7 O GOVERNO LULA DA SILVA E A SEGUNDA RENOVAÇÃO DA LEI DE INFORMÁTICA........ 145

3.8 A INDÚSTRIA DE INFORMÁTICA NO MUNDO E A ABERTURA DE MERCADO NO BRASIL.... 154

3.9 RESULTADOS DA POLÍTICA DE INFORMÁTICA BRASILEIRA A PARTIR DOS ANOS NOVENTA 161

3.10 ANÁLISE DA POLÍTICA DE INFORMÁTICA À LUZ DOS ELEMENTOS TEÓRICOS . 175

\section{CAPÍTULO 4. TEMAS E INSTRUMENTOS JURÍDICOS RELEVANTES DA} POLÍTICA DE INFORMÁTICA................................................................................ 187

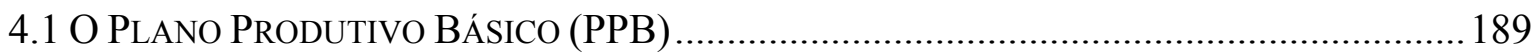

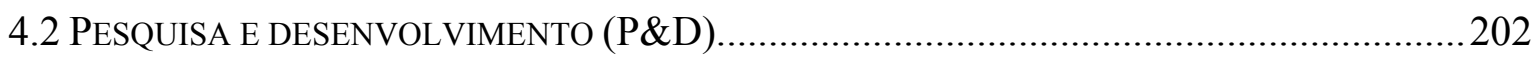

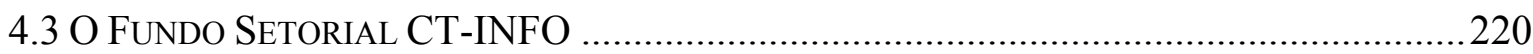

4.4 INSTRUMENTOS JURÍDICOS RELEVANTES DA POLÍTICA DE INFORMÁTICA ......................233

CONCLUSÕES E LIÇÕES DO ESTUDO_.........................................................238

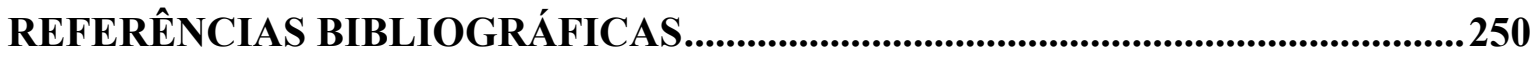




\section{RESUMO}

O objetivo central desta dissertação é realizar uma análise crítica da política de informática brasileira adotada na década de noventa sob uma perspectiva jurídica. O mote principal é utilizar a Lei de Informática (Lei 8.248/91 e modificações posteriores), seus dispositivos e incentivos, tanto como objeto de análise quanto como centro de referência para compreensão do setor e da política pública adotada. A questão que se propõe responder é que papel pode ser atribuído ao direito dentro de uma política pública setorial voltada ao desenvolvimento de uma indústria de grande importância na economia contemporânea e com alta dinâmica tecnológica como o setor de informática. Na primeira parte realiza-se uma revisão da literatura econômica sobre política industrial e intervenção do Estado na economia, a fim de se estabelecer os marcos teóricos do estudo empírico. Nos dois capítulos subseqüentes é feita a reconstrução histórica da antiga política de informática (a reserva de mercado) dos anos setenta e oitenta, e do novo conjunto de incentivos instituídos nos anos noventa com a Lei de Informática, tentando entender porque uma política inicialmente pensada para durar até 1997 já foi renovada por duas vezes, tendo por prazo atual de duração o ano de 2019. Também é realizado um estudo das três principais ferramentas jurídicas adotadas na nova política (o Plano Produtivo Básico, as exigências de pesquisa e desenvolvimento e o fundo setorial CT-Info), abordando a racionalidade adotada para atacar os problemas identificados, e como o direito e o arcabouço normativo se encaixam e são utilizados dentro dessa racionalidade. Ao final, tenta-se retomar sinteticamente as análises anteriores, respondendo à pergunta sobre a função do direito em três frentes: (i) como elemento que, uma vez positivado como norma jurídica, exerce influência para a evolução ou evolver posterior da política; (ii) como ferramenta jurídica de política industrial utilizada pela Lei de Informática; e (iii) como elemento explicativo fundamental para compreender a própria construção e desenvolvimento do mercado de informática no país. 


\begin{abstract}
The main purpose of this essay is to critically analyze under a legal perspective the Brazilian informatics policy adopted during the nineties. The strategy may be described as using the Informatics Law (Law $\mathrm{n}^{\circ} 8.248 / 91$ and latter amendments), its rules and incentives as the central object of analysis and as a guidance to understand the industry and the public policy. The question to be answered herein is what role may be ascribed to Law in an industry targeted public policy aimed at promoting the development of an industry of great importance in today's economy and with high technological dynamics such as the informatics industry. The first part reviews the economic literature on industrial policy and State intervention in the economy, in order to establish the theoretical grounds of the empirical study. In the two subsequent chapters there is a historical analysis of the former informatics policy (the market reserve) in the seventies and the eighties, and of the new policy established with the Informatics Law in the nineties, arguing why a policy initially thought to last up to 1997 was renewed twice already, with a current deadline in 2019. It is also presented a research on the three most important legal instruments of the new policy (the "Basic Productive Plan", the investments required on research and development and the industry specific fund CT-Info), including a study of the rationale intended to correct the identified problems, and how the Law and legal arrangements fit and were used within such rationalities. Finally, the main theses defended along the essay are jointly reviewed, thus answering the question regarding the role of Law in three different ways: (i) as an element that, once approved as legal provision, exerts influence on the further evolution of the public policy in question; (ii) as an industrial policy legal instrument used within the Informatics Law; and (iii) as a fundamental explanatory element to comprehend the constitution and development of the Brazilian informatics market itself.
\end{abstract}




\section{SIGLAS E ABREVIAÇÕES UTILIZADAS}

II PND - II Plano Nacional de Desenvolvimento

ABICOMP - Associação Brasileira de Computadores e Periféricos

ABINEE - Associação Brasileira da Indústria Elétrica e Eletrônica

ABNT - Associação Brasileira de Normas Técnicas

ASSESPRO

BNDE - Banco Nacional de Desenvolvimento Econômico

BNDES - Banco Nacional de Desenvolvimento Econômico e Social

CAPES - Coordenação de Aperfeiçoamento de Pessoal de Nível Superior

CAPRE - Coordenação das Atividades de Processamento Eletrônico

CATI - Comitê da Área de Tecnologia da Informação

CCTCI - Comissão de Ciência, Tecnologia, Comunicação e Informática da Câmara dos Deputados

CDE - Conselho de Desenvolvimento Econômico

CEITEC - Centro de Excelência em Tecnologia Eletrônica Avançada

CI/SEI - Comissão de Informática da SEI

CIDE - Contribuição sobre a Intervenção sobre o Domínio Econômico

CKD-completely knocked-down ou complete knock-down

CNAE - Classificação Nacional de Atividades Econômicas

CNI

CNPQ - Conselho Nacional de Desenvolvimento Científico e Tecnológico

COBRA - Cobra Computadores e Sistemas Brasileiros Ltda.
CONCEX - Conselho Nacional do Comércio Exterior

CONIN - Conselho Nacional de Informática e Automação

CSN - Conselho de Segurança Nacional

DEPIN - Departamento de Política de Informática e Automação

FIESP - Federação das Indústrias do Estado de São Paulo

FINEP - Financiadora de Estudos e Projetos

FNDCT - Fundo Nacional de Desenvolvimento Científico e Tecnológico

FUNTEC - Fundo de Financiamento TécnicoCientífico

GATT - Acordo Geral sobre Tarifas Aduaneiras e Comércio (General Agreement on Tariffs and Trade)

GEACE - Grupo Executivo para Aplicação de Computadores Eletrônicos

GTE - Grupo de Trabalho Especial

HARDWARE BR - Projeto, Manufatura e Qualificação da Eletrônica de Produtos com Tecnologia da Informação e Comunicação

IBGE - Instituto Brasileiro de Geografia e Estatística

IBI - Instituto Brasileiro de Informática

IBM - International Business Machines Corporation

IPEA - Instituto de Pesquisa Econômica Aplicada

IPI - Imposto sobre Produtos Industrializados

IR - Imposto sobre a Renda e Proventos de qualquer Natureza

ITA - Instituto Tecnológico da Aeronáutica

LSD da USP - Laboratório de Sistemas Digitais da Universidade de São Paulo

MC - Ministério das Comunicações 
MCT - Ministério da Ciência e Tecnologia

MDIC - Ministério do Desenvolvimento, Indústria e Comércio Exterior

MEFP - Ministério da Economia, Fazenda e Planejamento

MICT - Ministério da Indústria, Comércio e Turismo

MINIFAZ - Ministério da Fazenda

MITI - Ministério da Indústria e Comércio Internacional (Ministry of International Trade and Industry) do Japão

MRE - Ministério das Relações Exteriores

NPI - Nova Política Industrial lançada pelo governo federal em 1987.

PC - computador pessoal (personal computer)

PICE - Política Industrial e de Comércio Exterior lançada em 1990 pelo governo Collor de Mello

PLANIN - Plano Nacional de Informática e Automação

PNM Design - Programa Nacional de Microeletrônica

PPB - Plano Produtivo Básico

ProTeM-CC - Programa Temático

Multiinstitucional em Ciência da Computação

PUC-RJ - Pontifícia Universidade Católica do Rio de Janeiro

RDC-TIC - Programa Rede de Desenvolvimento de Competências em Tecnologias da Informação e Comunicação

RNP - Rede Nacional de Pesquisa

SCT - Secretaria de Ciência e Tecnologia

SEI - Secretaria Especial de Informática

SEPIN - Secretaria de Política de Informática e Automação

SERPRO - Serviço Federal de Processamento de Dados

SNI - Serviço Nacional de Informação
SOFTEX 2000 - Programa Nacional de Software para Exportação

STF - Supremo Tribunal Federal

SUCESU

USP - Universidade de São Paulo

USTR - United States Trade Representative

ZFM - Zona Franca de Manaus 


\section{CONSIDERAÇÕES INICIAIS}

\section{Apresentação}

Esta dissertação foi inicialmente pensada à época das discussões parlamentares e promulgação da Lei 11.077/04, que renovou os incentivos fiscais da chamada Lei de Informática (Lei 8.248/91). Essa lei, em princípio, tinha por objetivo a concessão de benefícios temporários (até 1997 ou 1999) às empresas locais para que estas, através de medidas de competitividade e inovação tecnológica, pudessem enfrentar a abertura de mercado iniciada na década de noventa.

A prorrogação desses incentivos (lembrando-se que já haviam sido prorrogados anteriormente pela Lei 10.146/01) foi considerada um indício de que havia falhas na formulação ou implementação da política de informática ${ }^{1}$, e de que esta mereceria um estudo crítico aprofundado e possivelmente reformas para atingir seus objetivos iniciais. Assim, propus-me a realizar este estudo, sob uma perspectiva jurídica focada com questões de desenvolvimento econômico e social do país, indagando que contribuições o direito, entendido ao longo deste texto em sentido amplo como um arcabouço normativo complexo, forneceu para uma política pública adequada à realidade do setor. O mote principal é utilizar a Lei de Informática, seus dispositivos e incentivos, tanto como objeto de análise quanto como centro de referência para compreensão do setor e da política pública adotada. Pretendo, dessa forma, examinar a evolução e o desenho institucional e normativo desta política, buscando identificar, de um lado, seus determinantes políticos e econômicos, bem como suas bases teóricas de sustentação, e, de outro, indagar de seus resultados ao longo dessa trajetória.

\footnotetext{
${ }^{1}$ Não sendo meu objetivo fazer uma investigação teórica mais profunda sobre a idéia de política pública no âmbito do Direito Administrativo ou Econômico, adoto, sem maiores reservas, os conceitos e idéias de Dallari Bucci, para quem a introdução de políticas públicas é resultado da emergência do Estado-providência, simbolizando a superação da idéia anterior de "government by law". A novidade nas políticas públicas estaria na negação da racionalidade tradicional da norma jurídica geral e abstrata ("se-então"), introduzindo assim as idéias de finalidade e programa de ação ("fim-meio"). Na visão da autora, as políticas públicas aproximam-se do conceito de atividade, um conjunto de normas e atos (governamentais) que, tendo algum concerto ou coerência interna, tendem à realização de alguma finalidade. (DALLARI BUCCI, 2002, pp. 252-255).
} 
Política Industrial e direito

Ao longo da pesquisa pretendi dialogar com o debate teórico sobre política industrial e desenvolvimento, tentando extrair lições e contribuições que pudessem ser úteis a uma análise jurídica, ainda que interdisciplinar.

Considerando as pesquisas e a literatura até aqui consultada, identifiquei uma escassez de trabalhos jurídicos que trataram do assunto ou que podem ser considerados de grande relevância para esse tema. Conforme procuro demonstrar com a revisão do debate realizada no Capítulo 1, os principais autores e questões discutidas são de cunho econômico, o que não significa que seja um debate alheio ao direito. Pelo contrário, é um tema que, acredito, apresenta grande interesse e sinergia com o direito, uma vez que trata do envolvimento e atuação estatal na economia para promoção de determinadas finalidades.

Uma literatura jurídica que se aproximou desse tema e merece referência é o movimento que ficou conhecido por "Law and Development". Desenvolvida a partir da década de sessenta e eminentemente produto das escolas norte-americanas. Essa literatura deriva da demanda de fundações e agências do governo por propostas para seus programas de ajuda e desenvolvimento em países de terceiro mundo. Seu fundamento encontrava-se principalmente em um forte otimismo sobre o Estado e o ordenamento jurídico como promotores do desenvolvimento econômico. Partindo dessa premissa, fazia-se um diagnóstico de que as nações latino-americanas e outras tinham uma "cultura jurídica" (legal culture) muito formalista e pouco instrumental, sendo necessária uma reforma no ensino e sistema jurídico que geraria transbordamentos (spill-overs), aumentando a eficiência da economia. (TRUBEK, 2003, pp. 3-5). Conforme uma releitura recente de Trubek,

\footnotetext{
"A política de desenvolvimento enfatizava o papel do Estado em gerenciar a economia e transformar sociedades tradicionais. Praticantes do desenvolvimento assumiram que o direito poderia ser utilizado como uma ferramenta para o gerenciamento econômico e como uma alavanca para mudança social [...] $\mathrm{O}$ Primeiro Momento [do Law and Development movement] reforçava a importância do direito como um instrumento para intervenção estatal efetiva na economia". (TRUBEK E SANTOS, 2006, p. 2, tradução nossa²).
}

\footnotetext{
2 "Development policy focused on the role of the state in managing the economy and transforming traditional societies. Development practitioners assumed that law could be used as a tool for economic management and a lever for social change. [...] First Moment doctrine stressed the importance of law as an instrument for effective state intervention in the economy". (TRUBEK E SANTOS, 2006, p. 2).
} 
Essas idéias, no entanto, entram em crise na década de setenta, e o modelo de sistema jurídico e de reformas legais proposto (o "legalismo liberal") foi tomado por etnocêntrico e até mesmo ingênuo por alguns de seus próprios formuladores, que reconheceram utilizar características que não estavam de acordo com a realidade institucional de países de terceiro mundo (principalmente, estratificação social e autoritarismo político). (TRUBEK E GALANTER, 1974, pp. 1080-1082).

A década de noventa vê um ressurgimento dessa doutrina, ancorada principalmente nas iniciativas do Banco Mundial de reformas institucionais e promoção do rule of law em países subdesenvolvidos. E, mais recentemente, um grupo de autores vem tentando retomar a idéia e as teorias de relacionar desenvolvimento com reformas no arcabouço jurídico e aparato estatal ${ }^{3}$.

Dois autores dessa nova fase especialmente relevantes para esta dissertação são Duncan Kennedy e David Kennedy, por suas contribuições a uma proposta metodológica e por tentar relacionar direito com o tema da política industrial, ainda que de forma não específica e dentro de um contexto mais amplo. Ambos os autores realizam uma retomada das idéias que relacionam direito, economia e desenvolvimento, inserindo-as em um contexto histórico e quadro evolutivo. A partir dessas considerações, é feito um exercício de identificação e classificação do papel exercido ou proposto para o direito em cada um dos momentos ou pelas escolas de pensamento identificadas. Os autores tentaram responder como a visão acerca da estrutura jurídica como elemento de uma estratégia desenvolvimentista foi influenciada pela dinâmica econômica e política, e pela evolução dessas idéias.

Duncan Kennedy sugere ter havido 3 globalizações desde meados do século XIX, cada uma trazendo uma diferente carga ideológica e política para o papel do direito. Embora seja uma tarefa difícil sintetizar a classificação do autor, devido ao grande número de informações e argumentos levantados, apresento abaixo uma tabela que tenta resumir os pontos que julguei mais relevantes para esta dissertação.

\footnotetext{
${ }^{3}$ Davis e Trebilcock (2008) realizam uma revisão desta literatura, citando como expoentes do ressurgimento destas teorias os trabalhos de Carothers (2006), Trubek e Santos (2006) e Dam (2006).
} 


\section{O DIREITO E AS “3 GLOBALIZAÇÕES” DE DUNCAN KENNEDY}

\begin{tabular}{|c|c|c|c|}
\hline & $1^{a}$ globalização & $2^{a}$ globalização & $3^{\text {a }}$ globalização \\
\hline Período histórico & $1850-1914$ & $1900-1968$ & $1945-2000$ \\
\hline $\begin{array}{l}\text { Conceito jurídico } \\
\text { central ou integrador }\end{array}$ & $\begin{array}{l}\text { Pensamento Jurídico } \\
\text { Clássico (Classical Legal } \\
\text { Thought) }\end{array}$ & Direitos sociais ("The Social”) & $\begin{array}{l}\text { Ausência de conceito: resgate e } \\
\text { transformação dos anteriores }\end{array}$ \\
\hline $\begin{array}{l}\text { Principal técnica } \\
\text { jurídica ou } \\
\text { metodologia }\end{array}$ & $\begin{array}{l}\text { Formalismo - dedução de } \\
\text { resultados dentro de um } \\
\text { sistema jurídico coerente e } \\
\text { autônomo }\end{array}$ & $\begin{array}{l}\text { Abordagem instrumental; desenvolvi- } \\
\text { mento racional do direito como um meio } \\
\text { para atingir metas sociais }\end{array}$ & $\begin{array}{l}\text { Neoformalismo aplicado ao } \\
\text { Direito Público - garantia de } \\
\text { efetivação de direitos humanos e } \\
\text { análise política (policy analysis) }\end{array}$ \\
\hline Função do direito & $\begin{array}{l}\text { Proteção da propriedade } \\
\text { privada e de transações } \\
\text { comerciais }\end{array}$ & $\begin{array}{l}\text { Complementar relações de mercado. } \\
\text { Quadro normativo conscientemente } \\
\text { elaborado para atingir finalidades sociais. } \\
\text { Construção do welfare state e estratégias } \\
\text { desenvolvimentistas (industrialização por } \\
\text { substituição de importações) }\end{array}$ & $\begin{array}{l}\text { Contrapor e harmonizar direitos } \\
\text { conflitantes de diversos grupos e } \\
\text { pluraridades }\end{array}$ \\
\hline
\end{tabular}

(Fonte: Duncan Kennedy, 2006, pp. 19-73)

Já David Kennedy se propõe a elucidar como evoluiu o conceito de desenvolvimento, particularmente na perspectiva econômica e política. A partir da revisão desta literatura, o autor tenta fazer uma "engenharia reversa" nas idéias desses pensadores (KENNEDY, 2006, p. 102), para captar e explicitar o que há de jurídico ou normativo em suas recomendações e análises, e dessa forma extrair o objetivo pretendido para o arcabouço institucional e normativo. Kennedy divide a compreensão da idéia de desenvolvimento em 4 etapas, resumidas no esquema abaixo, com as mesmas reservas levantadas para a tabela anterior.

DIREITO E AS IDÉIAS DE DESENVOLVIMENTO - DAVID KENNEDY

\begin{tabular}{|c|c|c|c|c|}
\hline & $\begin{array}{c}\mathbf{1}^{\mathrm{a}} \text { fase } \\
\text { "Consenso do Pós- } \\
\text { guerra" }\end{array}$ & $\begin{array}{l}2^{a} \text { fase } \\
\text { "Crise" }\end{array}$ & $\begin{array}{c}3^{\mathrm{a}} \text { fase } \\
\text { “Consenso de } \\
\text { Washington" }\end{array}$ & $\begin{array}{c}4^{\text {a }} \text { fase } \\
\text { "Neoliberalismo } \\
\text { ameaçado" }\end{array}$ \\
\hline Período histórico & $1945-1970$ & 1970-1980 & 1980-1995 & 1995-2005 \\
\hline $\begin{array}{l}\text { Contexto das idéias } \\
\text { sobre } \\
\text { desenvolvimento }\end{array}$ & $\begin{array}{l}\text { "Intervencionismo } \\
\text { modesto"; industria- } \\
\text { lização por substi- } \\
\text { tuição de importa- } \\
\text { ções; e } \\
\text { keynesianismo e } \\
\text { macroeconomia } \\
\text { ditam agenda gover- } \\
\text { namental. }\end{array}$ & \begin{tabular}{l}
\multicolumn{2}{c}{ Desapontamento com } \\
políticas
\end{tabular} & $\begin{array}{l}\text { Neoliberalismo; racionalida- } \\
\text { de microeconômica passa a } \\
\text { dominar o debate; governo } \\
\text { deve garantir funcionamento } \\
\text { do mercado; "Get the prices } \\
\text { right" - ataque a políticas } \\
\text { protecionistas que distorcem } \\
\text { preços; temas neoliberais - } \\
\text { public choice, rent-seeking, } \\
\text { e second-best economics. }\end{array}$ & $\begin{array}{l}\text { Desapontamento com os } \\
\text { resultados do "choque } \\
\text { neoliberal"; neoliberalismo } \\
\text { continua sendo o principal } \\
\text { paradigma, mas emergem } \\
\text { novas idéias - Neoinsti- } \\
\text { tucionalismo, Desenvol- } \\
\text { vimento e direitos } \\
\text { humanos (Amartya Sen) }\end{array}$ \\
\hline $\begin{array}{l}\text { Teoria jurídica } \\
\text { implícita nas idéias } \\
\text { analisadas e papel } \\
\text { do direito }\end{array}$ & $\begin{array}{l}\text { Direito instrumental } \\
\text { e a serviço de } \\
\text { propósitos sociais e } \\
\text { desenvolvimentistas; } \\
\text { e necessidade de } \\
\text { novos institutos de } \\
\text { Direito Público para } \\
\text { práticas protecio- } \\
\text { nistas }\end{array}$ & $\begin{array}{l}\text { Continuidade do período } \\
\text { anterior - direito como } \\
\text { instrumento de imple- } \\
\text { mentação de política } \\
\text { social; e primeiro mo- } \\
\text { mento do "Law and } \\
\text { Development" - antifor- } \\
\text { malismo e pragmatismo. }\end{array}$ & 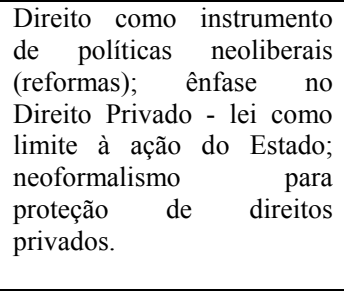 & $\begin{array}{l}\text { Direito continua } \\
\text { instrumental, mas adquire } \\
\text { nova dimensão como um } \\
\text { "fim em si mesmo"; e } \\
\text { direitos humanos e rule of } \\
\text { law passam a integrar a } \\
\text { própria definição do } \\
\text { Estado desenvolvido. }\end{array}$ \\
\hline
\end{tabular}

(Fonte: David Kennedy, 2006, pp. 95-173)

Meu interesse nos trabalhos e classificações propostas por estes autores está em sua capacidade de pensar o direito a partir de uma determinada conjuntura político-econômica 
ou de idéias e teorias (majoritariamente econômicas). Ademais, suas análises os levam a sugerir papéis ou funções exercidos pela estrutura jurídica, trazendo um vocabulário e uma tipologia que podem ser utilizados no decorrer de meu estudo empírico ("direito instrumental", "direito como meio de implementação de políticas", "direito como fim em si mesmo"), quando busco compreender como a política de informática conseguiu (ou fracassou em) influenciar a dinâmica e a evolução do setor.

Noto que, à parte dos artigos citados, a literatura jurídica analisada trata da relação entre direito e desenvolvimento de uma forma abstrata, não tendo sido encontradas maiores referências sobre o debate de política industrial ou intervenções verticais na economia ${ }^{4}$. No curso de minhas pesquisas, tive grande dificuldade em localizar trabalhos de juristas dedicados ao desenvolvimento industrial, seja acerca de suas condições institucionais ou dos mecanismos e racionalidades de fomento estatal. Em especial, me ressenti da ausência de uma sistematização teórica mais profunda, que me fornecesse um ferramental metodológico mais adequado para a análise de políticas públicas de estímulo setorial.

Nesse contexto, a proposta de um estudo de caso me pareceu oportuna e adequada. Já que não se encontra disponível um conhecimento jurídico consolidado, procurarei compreender como a relação direito e (tentativa de) desenvolvimento industrial se deu em um caso específico e concreto, através de um estudo que privilegia os aspectos empíricos de uma política pública constituída e implementada em um dado momento (mantendo-se o recurso ao referencial teórico adequado). Ainda que se possa objetar que isso limita a extensão das conclusões a serem tiradas, certamente elas poderão contribuir para a construção de um quadro teórico ou analítico mais abrangente que supra essa deficiência que encontro na literatura.

\section{Tecnologia e progresso econômico}

O avanço tecnológico e suas repercussões na economia é um tema que interessou já aos primeiros economistas. Smith fez menção ao progresso técnico, ao descrevê-lo como fruto do processo de maturação da economia e da divisão do trabalho. (SMITH, 1980, p. 16-17). Mas é apenas com Marx que a mudança tecnológica vai ganhar contornos teóricos mais definidos, sendo entendida como essencial e indissociavelmente entrelaçada à

\footnotetext{
${ }^{4}$ Uma exceção é o trabalho de Trubek (1993), que faz uma reconstrução histórica de políticas protecionistas até a atualidade.
} 
emergência histórica do modo de produção capitalista. Na visão de Marx, o capitalismo leva a uma imensa expansão da produtividade e capacidade de produção humana. A própria existência do capitalismo (e da burguesia como sua classe dominante) dependeria do constante aprimoramento das formas de produção. (MARX E ENGELS, 2002, pp. 2829). Marx buscou ainda compreender como a mudança técnica altera as relações de produção, aumentando a produtividade do trabalho, e com ela, o trabalho excedente e a taxa de mais-valia.

Schumpeter, no início do século XX, apresenta a inovação como o "fenômeno fundamental" que traz a ruptura ao fluxo circulatório em pretenso equilíbrio na economia capitalista. A inovação é introduzida no sistema pela figura do "empresário", indivíduo que, em determinado momento, aceita o desafio e o risco de alterar o estado de produção atual em busca de lucro. A inovação rompe o equilíbrio do estado estacionário, através do que o autor denominou ondas primárias e secundárias. $\mathrm{O}$ empresário e seus primeiros seguidores (ou imitadores) conseguem inicialmente obter um alto lucro pela introdução da inovação, lucro esse que acaba por ser corroído pela entrada de novos agentes utilizando a mesma técnica ou aderindo ao novo mercado. (CRUZ, 1988, p. 437).

Nas décadas de cinqüenta e sessenta, diversos estudos tentaram medir a contribuição da mudança tecnológica para o crescimento econômico. O principal exemplo é o tradicional modelo neoclássico desenvolvido por Solow, que busca compreender a contribuição da mudança técnica (o "resíduo de Solow") no aumento da produtividade. (SOLOW, 1957).

Esta brevíssima menção a alguns grandes clássicos do pensamento econômico ${ }^{5}$ ilustra que o permanente avanço técnico na produção foi desde cedo compreendido como essencial na gênese e funcionamento do sistema capitalista, assim como para a constante “destruição criadora” que o revoluciona e caracteriza, e, por fim, para o aumento da produtividade e melhoria das condições de vida. Foi só mais tardiamente que economistas e historiadores econômicos começaram a dar maior atenção às peculiaridades e fatores institucionais que favorecem ou inibem a inovação, e à responsabilidade do Estado

\footnotetext{
${ }^{5}$ Para uma revisão mais ampla e sistematizada da literatura sobre o tema, ver ROSENBERG, 2006, pp. 1765.
} 
nacional na adoção de mecanismos e medidas nesse sentido ${ }^{6}$. Esse debate, conforme será abordado, é extenso e complexo, havendo inúmeras controvérsias sobre os mais diversos aspectos do desenvolvimento e atraso tecnológico das nações.

A pesquisa proposta diz respeito especificamente a esse debate. Pretendo dialogar com a literatura relevante e utilizá-la como fundamentação teórica para um estudo de caso, uma análise de um conjunto de medidas e ações governamentais que, em um dado momento histórico no Brasil, propôs-se a incentivar e modernizar um setor da economia o setor de equipamentos e peças para informática. Lançando um olhar profundo sobre esse conjunto de políticas, buscarei compreender suas origens, teóricas e políticas, seus métodos e racionalidades, e, por fim, suas realizações e repercussões sobre o desempenho econômico e tecnológico e sobre os rumos tomados pelo setor no período.

\section{O setor de informática em Moore e Solow}

É importante ainda fazer uma breve referência ao setor econômico escolhido para a pesquisa. Uma descrição mais detalhada da evolução da informática no país e no plano internacional será fornecida nos capítulos 2 e 3, juntamente com o retrospecto da política. Cabe, todavia, apresentar uma justificativa para essa decisão, indicando a importância do setor com a discussão teórica a ser travada no primeiro capítulo. Trata-se, assim, de se indagar qual é a relação da indústria de informática com o desenvolvimento econômico e tecnológico, ou seja, explicar porque esse setor é importante para o debate do desenvolvimento, merecendo ser objeto de uma política industrial.

Atualmente essa questão pode parecer um pouco fora de contexto. Em especial no tocante ao consumo e utilização de produtos, não parece mais razoável questionar a importância da informática para os negócios e para a vida pessoal (sem esquecer obviamente o cenário de exclusão digital que impera em largas partes do planeta). Melhoria na qualidade e velocidade da comunicação, automação industrial e armazenamento e organização de dados e informações são alguns (evidentes) exemplos de benefícios trazidos pela indústria de informática.

\footnotetext{
${ }^{6}$ A esse respeito ver ROSENBERG, 2006, e KIM E NELSON, 2005.
} 
A alta dinâmica tecnológica fez do setor de TI (Tecnologia da Informação) um caso único de aumento expressivo e sustentável da qualidade e capacidade de seus produtos. Desde o seu surgimento, já faz algumas décadas que esta tecnologia vem exponencialmente aumentando sua capacidade de armazenamento, análise e transmissão de dados, acompanhada de uma constante redução dos preços. O investimento relativo e absoluto das empresas em TI cresceu consideravelmente, especialmente a partir dos anos oitenta, e esses equipamentos tornaram-se uma parte indispensável do capital fixo em diversos ramos de atividade, incluindo a governamental.

Essa capacidade de reprodução e expansão contínua da informática já havia se revelado desde o seu início. Em 1965, Gordon Moore, que viria a ser um dos fundadores da Intel, expôs uma previsão sobre o aumento da potência dos computadores. Segundo a 'Lei de Moore', como ficou conhecida, o número de transistores em um único chip deveria dobrar em cada período de 18 a 24 meses, o que representa uma taxa de crescimento anual em torno de $35 \%$ a $45 \%$. A despeito de controvérsias e debates acerca de seus termos, a Lei de Moore mostrou-se verdadeira ao longo do tempo, sendo capaz de representar (aproximadamente) o incremento tecnológico na indústria. Conforme estudo de Jorgenson, feito em 2001 (quase 4 décadas depois do trabalho de Moore):

\footnotetext{
"A previsão de Moore, feita na infância da indústria de semicondutores, acompanhou a capacidade de chip por trinta e cinco anos. E recentemente extrapolou esta tendência por pelo menos mais uma década. [...] As tendências de aumento acelerado da capacidade de microprocessadores e aparelhos de armazenamento ilustram o crescimento exponencial previsto pela Lei de Moore. O primeiro chip lógico em 1971 tinha 2.300 transistores, enquanto o Pentium 4 lançado em 20 de novembro de 2000 tinha 42 milhões!" (JORGENSON, 2001, pp. 5-6, tradução nossa ${ }^{7}$ ).
}

Devido a essa forte capacidade de progresso e o aumento de sua porcentagem sobre o produto total da economia, alguns economistas argumentam que a indústria de TI é, na verdade, a responsável pelos altos níveis do aumento da produtividade total apontados nas últimas décadas (uma vez que nos demais setores não vêm ocorrendo uma revolução tecnológica nos mesmos níveis). (BLANCHARD, 2007, p. 242).

\footnotetext{
7 "Moore's prediction, made in the infancy of the semiconductor industry, has tracked chip capacity for thirty-five years. He recently extrapolated this trend for at least another decade8. [...]The rapidly rising trends in the capacity of microprocessors and storage devices illustrate the exponential growth predicted by Moore's Law. The first logic chip in 1971 had 2,300 transistors, while the Pentium 4 released on November 20, 2000, had 42 million!". (JORGENSON, 2001, pp. 5-6).
} 
Isso não significa que haja consenso sobre a importância da informática para o aumento da produtividade e desenvolvimento econômico. Por sinal, até pouco tempo esse era um tema em aberto e inconcluso entre economistas. O chamado 'paradoxo de Solow' (ou paradoxo de produtividade de Solow), proposto por Robert Solow no final da década de oitenta, questionava a real importância da indústria de computadores para o crescimento da produtividade econômica. Utilizando seu ferramental metodológico ('resíduo de Solow'), foi verificado que a produtividade ou crescimento econômico diminuía para os dados a partir de 1973, período no qual os investimentos em computadores foram sistematicamente elevados. (JORGENSON E STIROH, 1999, p. 110). Daí a afirmação de Solow de que "se consegue ver a era dos computadores em todo lugar exceto nas estatísticas de produtividade”. (apud TRIPPLET, 1999, p. 309, tradução nossa ${ }^{8}$ ).

Pesquisadores e economistas se detiveram sobre o problema, tentando compreender, explicitar e solucionar o paradoxo. Atualmente, existem alguns melhores esclarecimentos a respeito. Os desenvolvimentos e indicadores econômicos posteriores ao trabalho de Solow indicaram que a indústria de informática gerou ganhos de produtividade, ainda que esses aumentos sejam dependentes e complementares a investimentos em habilidades (skills), organização e inovação, além de claros ganhos qualitativos, como redes de fornecedores e relações de consumidores ${ }^{9}$. (OCDE, 2004, p. 25).

Considerando o lado da produção e desenvolvimento, o setor é relevante e foi escolhido por apresentar uma grande convergência com o tema do aprimoramento tecnológico, demonstrando um extremo dinamismo. Conforme Evans justifica sua escolha pelo mesmo setor em sua obra, o setor de informática é de grande interesse devido ao seu potencial em gerar um ciclo desenvolvimentista ("catalizar uma conspiração a favor do desenvolvimento"), modificando assim a atual conjuntura econômica internacional e a divisão internacional do trabalho. Nesse sentido, estudar este setor neste momento é

\footnotetext{
8 "you can see the computer age everywhere but in the productivity statisctics". (apud TRIPPLET, 1999, p. 309).

9 Jorgenson e Stiroh admitem a resolução do paradoxo analisando a queda dos preços dos equipamentos de informática e o mercado de serviços, além dos ganhos para consumidores. "The resolution of the Solow paradox is that computer-related gains, large returns to the production and use of computers, and network effects are fundamentally changing the U.S. economy. However, they are not ushering in a period of faster growth of output and total factor productivity. Rather, returns to investment in IT equipment have been successfully internalized by computer producers and computer users. These economic agents are reaping extraordinary rewards for mobilizing investment resources and restructuring economic activities". (JORGENSON E STIROH, 1999, pp. 109-115).
} 
especialmente conveniente, pela chance de averiguar o papel da intervenção estatal nesse processo e os frutos gerados. (EVANS, 2004, p. 36). Além disso, o setor de informática no Brasil vem apresentando um forte crescimento e integração na vida econômica e social dos indivíduos, governos e empresas, atuando como insumo e balizador tecnológico do funcionamento de diversos outros campos da economia.

\section{O tema e objetivos da dissertação}

Na perspectiva de um estudo de caso, o objetivo principal desta pesquisa é a análise crítica da política pública e do conjunto de medidas e instrumentos voltados ao setor de equipamentos e peças de informática formuladas e implementadas no Brasil, e demais instrumentos normativos e aspectos institucionais ${ }^{10}$ relacionados. Sob um prisma mais amplo, pretendo fornecer subsídios empíricos que possam ajudar (i) a informar o debate sobre os fatores institucionais e instrumentos de fomento adequados à inovação tecnológica, bem como os problemas e questões que possam afetar seus resultados, e (ii) a responder e identificar que papel (ou papéis) pode ser atribuído ao direito (e, por conseguinte, à pesquisa jurídica), dentro de uma política pública setorial voltada ao desenvolvimento de uma indústria de grande importância e com alta dinâmica tecnológica, no contexto econômico contemporâneo de economias nacionais abertas ao mercado externo e sujeitas à concorrência internacional.

Para atingir essas metas, tomo por tarefas ou escolhas de pesquisa: (i) elaborar um retrospecto histórico da política de informática, tentando identificar os fatos e instrumentos jurídicos mais relevantes que permitam compreender o curso da política e de suas realizações, e (ii) realizar uma análise crítica dos resultados da política e da função que pode ser atribuída ao direito, enquanto seu arcabouço normativo, relacionando-os com o

\footnotetext{
${ }^{10}$ Tendo em vista os objetivos do projeto é conveniente abordar brevemente o debate teórico sobre o termo "instituição", bem como esclarecer a definição adotada. Na conhecida conceituação de North, instituições são as regras do jogo em uma dada sociedade, ou, formalmente, são os limites que vão delinear a ação humana. (apud ACEMOGLU, JOHNSON E ROBINSON, 2004, p. 1). Chang e Evans identificam três principais linhas de pensamento que buscam definir instituições: a Nova Economia Institucional, que compreende as instituições principalmente como "limitações" à ação humana, mas que podem aumentar a eficiência do mercado; em segundo lugar, os autores que vêem as instituições como mecanismos capacitadores (enabling), que geram as condições e o ambiente necessários para a atuação humana; e, por fim, aqueles que preconizam o aspecto constitutivo das instituições, o que implica reconhecer que elas influenciam e moldam os valores e perspectivas dos indivíduos sujeitos a elas, em uma relação de retro-alimentação mútua. (CHANG E EVANS, 1999, pp. 7-10). Para fins do estudo proposto, considero adequado adotar uma interpretação ampla e abrangente da idéia de instituições, uma vez que só assim faz sentido entender, com Acemoglu, Johnson e Robinson (2004, pp.2-3), que as instituições podem ser consideradas elementos chaves para explicação do crescimento econômico (e tecnológico) das nações, uma vez que moldam os incentivos dos agentes, influenciando seus investimentos em capital e tecnologia.
} 
debate teórico a ser estudado. Tratando-se de um trabalho de cunho jurídico, o enfoque será estabelecido a partir da legislação aplicável (incluindo atos normativos da burocracia econômica), que será o ponto principal de análise. O exame dessas normas, no entanto, não poderá se restringir ao estudo formal de seus dispositivos e regras. Estas devem ser contextualizadas e compreendidas juntamente com os momentos históricos nos quais foram promulgadas, em especial a situação da indústria de informática e os objetivos políticos e econômicos pretendidos pelos atores.

Partindo dessa legislação, buscarei entender suas repercussões no campo econômico, identificando como se comportou e desenvolveu o setor de informática brasileiro. Não há qualquer pretensão de estabelecer uma relação causal ou de determinação entre direito e economia, mas apenas de tentar apreender se e como, neste caso concreto, Estado, legislação e atores políticos foram capazes de empreender as modificações inicialmente imaginadas na indústria, e onde falharam em atingir esses objetivos.

Fazendo um recorte temporal, o principal objeto de estudo é a política implantada a partir da década de noventa. Essa escolha foi tomada devido à escassez de análises que procuraram entender o que houve com a indústria de equipamentos de informática brasileira nesse período. À parte do grande volume de dados estatísticos e econômicos do setor que podem ser obtidos, poucos estudos dedicaram-se de maneira mais sistemática a olhar todas essas informações e fazer uma investigação mais profunda sobre os reais impactos da Lei de Informática e demais medidas governamentais para incentivo ao setor a partir da década de noventa.

Todavia, no segundo capítulo é feito um retrospecto das medidas e da política desenvolvida no período anterior, especialmente nos anos setenta e oitenta. O objetivo desta retrospectiva é permitir uma contextualização do ambiente político e econômico no qual foi formulada e implementada a política atual, assim como fornecer um referencial de comparação, um diferente aparato institucional que possa ser considerado conjuntamente à política do período posterior.

Há ainda dois outros recortes a serem descritos para a definição mais precisa de meu objeto de estudo. Um primeiro refere-se ao âmbito federativo das normas e atos 
governamentais sob análise. Propõe-se investigar a política pública implementada exclusivamente pelo governo federal para todo o país. A idéia por trás desse corte é a de que, além da inviabilidade de se fazer uma análise de toda a legislação estadual e municipal relevante, as medidas de âmbito federal teriam uma maior importância e alcance para o tema. Não serão ainda objeto central desta investigação políticas regionais adotadas pelo governo federal, como a legislação de incentivo à ZFM (Zona Franca de Manaus). Poderão ser feitas algumas referências esparsas a esses programas de incentivo, com puro objetivo de ilustrar e complementar a análise da política sob enfoque.

Por fim, é necessário especificar o setor econômico a ser estudado, ou seja, o que se entenderá por "indústria de equipamentos e peças de informática". A CNAE (Classificação Nacional de Atividades Econômicas), que é o instrumento padronizador dos códigos de atividade econômica utilizado pelos órgãos da administração no país, apresenta uma rubrica para a "fabricação de equipamentos de informática, produtos eletrônicos e ópticos" (Seção C, Divisão 26) ${ }^{11}$. Entretanto, uma vez que a pesquisa está voltada a uma política pública, será mais adequado utilizar como critério balizador das investigações o conjunto de atividades e bens que se encontram previstos nos respectivos instrumentos de fomento e, mais importante, aqueles que, de fato, foram beneficiados pelas medidas arroladas. Nesse sentido, ao longo da dissertação buscarei na Lei de Informática e no conjunto de empresas e produtos credenciados pelo governo para receber seus incentivos os limites do setor econômico a ser estudado.

É ainda conveniente fazer um corte mais restrito no setor, excluindo de minha atenção principal as atividades de desenvolvimento e prestação de serviços relacionados a software. Esse corte justifica-se por duas razões fundamentais. Inicialmente, o setor de software apresenta uma dinâmica muito peculiar e distinta do setor de equipamentos de informática. A ausência de custos com matéria-prima, o baixo valor necessário para estabelecer uma empresa e o foco quase exclusivo na mão-de-obra especializada são características dessa indústria que não necessariamente encontram correspondência no setor de fabricação de equipamentos. Além disso, conforme será mencionado, um dos principais incentivos da Lei de Informática é a isenção ou redução do valor do IPI cobrado

11 Essa classe de atividades apresenta uma série de subgrupos pertinentes ao tema da pesquisa, como a fabricação de componentes eletrônicos (261), de equipamentos de informática e periféricos (262), de equipamentos de comunicação (263), e de mídias virgens, magnéticas e ópticas. 
dos produtos comercializados. No caso do software, no entanto, a maioria das empresas não se encontra sujeita a essa tributação, o que em grande parte torna inócua a política para esse setor. Portanto, não se poderia indagar dos resultados da Lei de Informática para o setor de software, o que justificaria sua exclusão do presente estudo.

Compreendo que, no atual contexto da informática, separar a evolução de hardware e software é uma decisão um tanto arbitrária e que em muitos aspectos não corresponde à realidade do setor. Esses dois conjuntos de bens ou produtos possuem uma relação muito estreita, sendo muito difícil compreender um sem a exata noção do outro. Esse recorte, todavia, mostrou-se necessário, pois abarcar o setor de software em minhas pesquisas geraria um incremento considerável de situações e casos (além dos elementos teóricos) a serem estudados. Ao invés disso, optei por não tratar especificamente da indústria de programas de computadores, apenas fazendo referência a ela nos momentos em que percebi que esta foi afetada pela política pública ${ }^{12}$.

Obtive respaldo para o recorte proposto analisando a lista de produtos atualmente beneficiados pela política. Não há, no âmbito dos programas incentivados, nenhum incentivo concedido exclusivamente para um programa de computador, exclusiva e separadamente considerado. Isso não significa que os equipamentos beneficiados não requeiram e disponham, para seu funcionamento, de um software adequado. Mas o benefício é sempre concedido para o equipamento, considerado em seu conjunto (hardware e software) $)^{13}$.

\section{Aspectos metodológicos}

Retomando a definição de política pública de Dallari Bucci (2002), a importância de uma política pública encontra-se em seu objetivo, na finalidade que ela busca alcançar ou problema a ser solucionado. Assim, a análise da conveniência e dos resultados de uma política não pode se restringir ao exame do ordenamento jurídico ou de sua coerência interna, nem ser encarada como um mero exercício dogmático-jurídico de construção da "resposta correta" ou da "única resposta juridicamente correta". Trata-se, muito

\footnotetext{
${ }^{12}$ Um exemplo é a destinação dos recursos de P\&D previstos na Lei para o desenvolvimento de software (ver capítulo 4, seção 4.2). Essas análises serão tangenciais e levarão em consideração apenas os aspectos relevantes para a pesquisa, sem pretensão de aprofundamento no cenário das empresas de software brasileiras.

${ }^{13}$ Análise própria, com dados disponíveis no website do Ministério da Ciência e Tecnologia.
} 
diferentemente, de abordar o problema desde uma perspectiva simultaneamente empírica e aplicada, constantemente preocupada em lidar com a realidade econômica, que com freqüência não se subordina aos desejos e às boas intenções do estudioso do direito excessivamente formalista.

Por esse motivo, a pesquisa proposta é multidisciplinar. Com isto quero afirmar que, conforme necessário, faço recurso de autores, temas, dados e análises utilizados em outros campos das ciências humanas. Ressalto que não é objetivo deste trabalho realizar uma análise puramente econômica do setor de informática, estudando dados desagregados para construção de modelos ou de um panorama conjuntural do setor. Minha proposta é utilizar estudos já realizados por economistas e outros cientistas sociais, conjugando-os com uma investigação jurídica da legislação e da política pública.

Esta análise jurídica será realizada principalmente com a finalidade de encontrar ou sugerir a função desempenhada pelo sistema jurídico ${ }^{14}$ em um dado contexto ou sua contribuição para uma determinada situação. Assim, a partir da narrativa histórica (parte empírica) da evolução da política de informática brasileira, entendo ser possível atribuir, ainda que de forma não determinista, alguns resultados e conseqüências às escolhas institucionais e quadro normativo da política de informática. Outro exercício de grande interesse será compreender como a dinâmica política e econômica do país em momentos específicos influenciaram as tomadas de decisão e a consequentemente a produção normativa referente à política.

Para essas tarefas, um ponto de partida são as classificações e vocabulário propostos por Duncan Kennedy e David Kennedy. A lista de finalidades a serem cumpridas pelo direito e a estrutura jurídica identificadas por esses autores sugerem abordagens teóricas a serem consideradas e aplicadas no decorrer do estudo empírico. Não pretendo, todavia, ater-me ou utilizar de maneira rígida, seus tipos ou termos levantados, principalmente porque não se pode afirmar que sejam amplamente reconhecidos e aceitos, e ainda por se aplicarem, em meu entender, mais a análises amplas e não específicas sobre o papel do direito e do Estado, enquanto nesta dissertação conduzo a análise de uma política pública em particular.

\footnotetext{
${ }^{14}$ Que poderá ser identificado como uma norma ou dispositivo específico, o marco regulatório do setor, ou mesmo o laconismo do ordenamento, como será proposto no capítulo 2.
} 
Feitas essas considerações, descrevo abaixo as premissas metodológicas adotadas em cada uma das partes seguintes da dissertação, conforme o foco e objetivo pretendidos:

a) o debate teórico pretende dialogar com os principais estudos e trabalhos que versaram sobre o Estado e política industrial. Será realizada a revisão da literatura sobre este tema, com o objetivo de compreender como cada escola ou corrente de pensamento econômico dialoga com esta matéria, tentando relacioná-las e analisá-las sob uma perspectiva crítica, almejando retirar lições que sirvam para pensar o caso brasileiro.

b) a revisão do histórico da política será feita com base nos relatos e informações divulgados e fornecidos pelos atores políticos e econômicos que participaram da política de informática, em notas divulgadas na imprensa, na legislação e atos normativos do Poder Executivo, e, finalmente, nos trabalhos de outros pesquisadores que já se debruçaram sobre o tema da indústria de informática no Brasil. Uma fonte especialmente relevante para compreender as nuanças e detalhes políticos envolvidos nas negociações e rumos escolhidos foram os debates parlamentares disponibilizados pela Câmara dos Deputados em sua página eletrônica. O resgate dessas discussões e de como se deram os acordos que levaram à legislação permite compreender de uma forma especialmente aprofundada como o direito interage e é influenciado por questões políticas e econômicas, enquanto ao mesmo tempo também determina e condiciona essas esferas das relações humanas.

c) a análise das ferramentas jurídicas selecionadas da política de informática deverá abranger o exame da legislação pertinente a cada tema, dos problemas que se buscou resolver, dos indicadores e resultados relacionados, além da opinião e investigação prévia de outros pesquisadores ou partes interessadas. O objetivo aqui será compreender que função pode ser atribuída ao direito e ao arcabouço normativo dentro da estratégia adotada, tentando ainda aliar um determinado aspecto institucional a uma conseqüência econômica ou a um problema que tenha impedido seus efeitos. A premissa desse capítulo (4) é de que é possível estabelecer alguma correlação entre a legislação e o quadro institucional estabelecido e determinadas repercussões no âmbito do setor e de sua estrutura de produção. 
Estrutura da dissertação

O primeiro capítulo que sucede a esta introdução estabelece os marcos teóricos do debate sobre intervenção estatal na economia e política industrial. As idéias, conceitos e principalmente a agenda de debate descrita neste capítulo são utilizados e retomados nos momentos posteriores, e servem de referencial de análise da parte empírica dos capítulos seguintes.

No segundo capítulo é relatada a história do setor de informática brasileiro e as políticas públicas desenvolvidas no país até a virada dos anos noventa. Os principais objetivos do capítulo são identificar as raízes e antecedentes de uma política de informática nacional e as transformações ocorridas até o movimento que se iniciou na década de noventa, compreendendo os motivos que levaram o governo federal a abandonar uma política quase unanimemente recebida alguns anos antes e que acabou quase completamente execrada quando de seu término; e resgatar a importância do que foi construído e gerado nesse período para o desenvolvimento posterior da indústria de informática brasileira.

O terceiro capítulo realiza a revisão histórica do principal objeto de análise desta dissertação: a política de informática desenvolvida pelo governo federal a partir dos anos noventa. Aqui ela é considerada em todo o seu conjunto, a fim de que seja possível analisar sua evolução, desde o período inicial de sua formulação até as renovações sucessivas na década seguinte. Um outro ponto abordado são os efeitos e repercussões alcançados, bem como as suas falhas e problemas.

Já o quarto capítulo realiza um recorte de três instrumentos jurídicos que compõem a política, para analisá-los separadamente. São medidas especialmente relevantes por seus resultados específicos e por sua importância na racionalidade do conjunto da política pública. São instrumentos ainda que merecem uma atenção detida pelos problemas e questões enfrentados ao longo de seu desenvolvimento, que serão estudados neste capítulo.

Por fim, a parte final do trabalho é responsável por resgatar as lições e conclusões auferidas ao longo da pesquisa, propondo uma resposta à pergunta sobre o papel do direito em todo o contexto estudado. 


\section{CAPÍTULO 1. O DEBATE TEÓRICO SOBRE POLÍTICA INDUSTRIAL E A FUNÇÃO DO ESTADO NA ECONOMIA}

A primeira tarefa para compreender uma política pública de desenvolvimento setorial é introduzir os marcos teóricos do debate sobre política industrial. A Lei de Informática e todo o conjunto de medidas correlatas possuem um forte viés do que é reconhecido como uma política vertical ou seletiva (conforme será definido e discutido mais adiante), ainda que seja muito menos protecionista do que a reserva de mercado anterior. Ao mesmo tempo, a Política Industrial e de Comércio Exterior - PICE introduzida no início dos anos noventa possuía um apelo de política horizontal, voltada à correção de falhas de mercado e promoção da concorrência com o mercado externo.

Essas são opções tomadas por um governante ou policy-maker para o desenvolvimento econômico local. São opções, em última análise, da política industrial a ser adotada, ou ainda, de se adotar ou não uma política industrial. As vantagens e desvantagens de cada uma dessas opções políticas são temas de um intenso debate na literatura econômica. Esse tema já conta com um razoável histórico, e as doutrinas que atualmente o abordam apresentam um grau de evolução avançado, tendo bases sólidas e argumentos bem elaborados. Nos dizeres de Chang, trata-se de um dos tópicos mais controversos da ciência econômica, desde o surgimento da disciplina. Embora seja razoavelmente consensual que o Estado tem um papel a cumprir no desempenho econômico e industrial, há pouco acordo sobre qual é esse papel e como ele deve ser exercido. (CHANG, 1996, p. 7).

Este capítulo será dedicado a estudar esse debate. Deverá apresentar as principais escolas que abordaram o assunto, traçando seus argumentos e racionalidades em autores clássicos e nos desenvolvimentos mais recentes. No entanto, tratando-se de uma dissertação voltada à ciência jurídica (ainda que interdisciplinar), seria inapropriado realizar uma exposição demasiado prolongada, abordando tópicos e instrumentos específicos e muitas vezes plenamente inteligíveis apenas aos iniciados nas ciências econômicas. 
Ao contrário, meu objetivo é aproximar este debate da pesquisa em direito, mostrando assim sua utilidade para juristas e pesquisadores dessa área em suas argumentações e trabalhos. Para tanto, acredito ser mais proveitoso estruturar este capítulo de forma curta e objetiva (dentro da possibilidade que permita uma exposição completa), atendo-me aos principais pontos que ajudem a esclarecer com precisão as bases, premissas e métodos utilizados pelas linhas de pensamento e autores, bem como suas descrições e prescrições com relação à função do Estado na economia e à política industrial.

O objetivo não será chegar a qualquer conclusão final no âmbito teórico, ou aderir de forma irrestrita a qualquer das doutrinas apresentadas. Tampouco, pretendo inserir e estudar a política de informática brasileira dentro de alguma modelagem. A identificação dos principais argumentos servirá para os seguintes propósitos: tentar compreender como as abordagens apresentadas relacionam-se e podem interagir com os resultados de uma pesquisa jurídica; e analisar questões e problemas relevantes levantados no estudo de caso à luz deste debate teórico.

Este capítulo encontra-se estruturado como segue. A primeira parte introduz o debate, apresentando as correntes teóricas a serem estudadas, e situando historicamente o seu surgimento ou apogeu. A segunda parte apresenta a teoria do bem-estar da escola neoclássica, que pode ser entendida como o mainstream ou a tradicional doutrina econômica sobre o tema. Na terceira parte é apresentada uma literatura mais recente que se posiciona contrariamente à intervenção estatal - o neoutilitarismo e a literatura de falhas de governo. A quarta seção descreve uma abordagem alternativa, a teoria evolucionária ou neoschumpeteriana, que tentou resgatar o papel do Estado no processo concorrencial, a partir do tema da inovação tecnológica. Por fim, na quinta e última parte, tenta-se resgatar as contribuições de cada escola, e chegar a um referencial adequado a ser utilizado no restante da dissertação.

1.1 Apresentação do debate: teorias da intervenção do Estado na economia e política industrial

Há muito foi-se o tempo em que, conforme Evans, as tarefas do Estado se resumiam à guerra externa e à manutenção da ordem interna. O Estado-nação, que tinha como preocupações quase exclusivas a defesa de seu território e o monopólio do uso da violência para manutenção da ordem, cedeu lugar a uma organização política com 
objetivos mais abrangentes no campo do bem-estar de suas populações e sucesso de seus empreendimentos. A despeito de alguns dogmas econômicos tradicionais, a economia adentrou na esfera política (se é que já esteve fora dela), e a paz nacional passou a depender ou ser perturbada pelo seu triunfo ou fracasso. O desempenho econômico tornouse fonte de legitimidade do sistema político. O Estado passou a ter alguma responsabilidade pelo funcionamento adequado dos mercados, pelo crescimento e distribuição da renda nacional e pela miséria que decai sobre sua população. (EVANS, 2004, p. 30).

Com o advento da indústria moderna e o incremento sistemático do comércio internacional de produtos manufaturados, a relação entre a economia interna dos países e sua posição no cenário de trocas globais torna-se mais estreita. A partir de então, a produção não pôde mais ser pensada em termos exclusivamente nacionais, dependendo do mercado e consumo externos de bens e serviços.

Uma vez que o aparato estatal adquiriu alguma responsabilidade pelo desempenho econômico, economistas e cientistas sociais dedicaram-se ao longo do tempo em formular modelos e análises teóricas que pudessem descrever e prescrever qual seria a função apropriada ou mais vantajosa a ser exercida por esta organização política. As perspectivas e recomendações variaram sensivelmente ao longo do tempo, levando em conta não apenas o desenvolvimento científico e metodológico como também questões históricas e políticas específicas de cada momento.

Os primeiros economistas clássicos (desconsiderando autores anteriores ligados ao pensamento fisiocrata e mercantilista) abordaram o tema com sério receio com relação à ação estatal, e uma crença exacerbada nas forças de mercado. Suas análises têm obviamente uma forte influência do momento histórico em questão que não poderia ser desprezada em uma exposição mais aprofundada. Para os fins desta dissertação, é suficiente explicitar que o legado desses autores, com relação a este tema, foi a conhecida defesa do Estado mínimo e da liberdade de comércio e empresa.

De uma forma extremamente simplificada, pode-se dizer que Smith considerava o capitalismo o estágio mais alto de civilização, que atingiria seu auge quando o governo pudesse adotar uma política plena de laissez-faire. Neste momento, as forças da 
concorrência e o livre jogo da oferta e da demanda regulariam a economia, livre das restrições e intervenções do governo. Para Smith, as intervenções, regulamentações e concessões de monopólio e os subsídios especiais do governo levam apenas à má alocação de capital. Mercados livres e com concorrência plena - são esses os fatores que, na exposição do autor, dirigem o capital para as indústrias e empreendimentos em que ele se faz mais produtivo. A conseqüência inescapável é a redução considerável das atribuições do Estado, restringindo-se apenas às suficientes para a manutenção da ordem e funcionamento dos mercados $^{1}$. (HUNT, 2005, pp. 54-57).

No plano do comércio internacional, a teoria das vantagens comparativas de Ricardo fez a principal defesa do livre comércio e da extinção das barreiras comerciais. Ricardo argumentou que, ainda que um país não tivesse uma vantagem absoluta em qualquer produto, o intercâmbio internacional seria sempre mutuamente benéfico. $\mathrm{O}$ clássico exemplo de trocas de tecidos e vinhos entre Portugal e Inglaterra ilustrava seu argumento, cuja conclusão era de que a ampliação do comércio sempre contribuiria para aumentar a massa de mercadorias e os benefícios totais. Toda restrição ao comércio, nessa lógica, reduziria o total de bem-estar.

A herança deixada por esses autores clássicos foi um paradigma de defesa do livre comércio e de um governo com atribuições reduzidas, que deveria se abster de interferir no âmbito privado e nos negócios comerciais, exceto quando estritamente necessário. Essa herança foi posteriormente tomada e formalizada de maneira mais rigorosa pelos autores da teoria econômica neoclássica, ao final do século XIX. Jevons, Menger e Walras formularam a versão atual da teoria do valor-utilidade e introduziram o "marginalismo" na ciência econômica (e, especialmente, a noção de utilidade marginal decrescente), o que permitiu a formalização matemática da visão utilitária do comportamento humano, através da ferramenta do cálculo diferencial (HUNT, 2005, p. 240).

A economia utilitarista representou o ápice na defesa ideológica do capitalismo laissez-faire. A economia neoclássica do bem-estar (welfare economics) e a sua defesa quase irrestrita do Estado mínimo permaneceram com grande força e mantendo essa posição original até meados da década de 50. Foi nessa época que economistas como

\footnotetext{
${ }^{1}$ Para um resumo das idéias de Smith ver HUNT, 2005, pp. 37-60.
} 
Arrow e Debreu flexibilizaram algumas das rígidas premissas dos modelos tradicionais, e identificaram algumas condições que deveriam ser (e diversas vezes não eram) satisfeitas, para os mercados atingirem resultados eficientes. Com o reconhecimento da existência das "falhas de mercado", a ortodoxia econômica passou a admitir a intervenção estatal em situações específicas e determinadas, com o objetivo de retornar os mercados ao cenário de concorrência perfeita e sua insuperável eficiência ${ }^{2}$. Noto que não foram superados o receio e desconfiança com relação à atuação estatal: as funções admitidas ao governo eram bem limitadas e com objetivos bem definidos, circunscritos por esses problemas de funcionamento perfeito dos mercados.

Conforme Wade, a idéia de falhas de mercado foi amplamente aceita, e, durante as décadas de cinqüenta e sessenta, o Estado foi regenerado como agente potencialmente restaurador da eficiência econômica e do bem-estar da população. Nos países desenvolvidos, a experiência da superação da recessão e o dirigismo do período de guerras forneciam a base empírica necessária, que confirmava a nova orientação teórica de redenção dos governos. (WADE, 1990, p. 8).

Economistas preocupados com os países menos desenvolvidos desenvolveram análises ainda mais confiantes e dependentes do Estado como agente de superação da pobreza e do subdesenvolvimento. O estruturalismo e a escola do subdesenvolvimento, elaborada especialmente no âmbito da Comissão Econômica para América Latina CEPAL, romperam com as perspectivas neoclássicas, destacando os efeitos deletérios do comércio internacional para os países subdesenvolvidos, e a importância da intervenção estatal na alteração dessa condição ${ }^{3}$.

As boas relações entre Estado e a ciência econômica tradicional duraram pouco tempo. Já nos anos setenta, a ofensiva do que se costumou chamar de neoliberalismo alterou profundamente os termos do debate, condenando novamente a economia direcionada ou alterada por decisões políticas, e reafirmando os cânones do livre mercado, em proporções ainda superiores àquelas descritas antes da década de 50. (CHANG, 2000, pp. 3-26). À idéia de falhas de mercado foi oposta uma nova noção, a de "falhas de governo" (government failure), que seria inerente a todos os estados. Nessa nova

\footnotetext{
${ }^{2}$ Para uma breve revisão dessa história ver STIGLITZ, 1996, pp. 151-177.

${ }^{3}$ Sobre o assunto ver BIELSCHOWSKY, 2000.
} 
perspectiva, a intervenção estatal, mesmo na presença de mercados não plenamente competitivos, constituía um remédio cujo resultado poderia (ou deveria) ser pior do que a própria falha original. Evans afirma que a desilusão com o Estado que se tornou endêmica na década de setenta é fácil de compreender a partir do quadro político dos países pobres ou em desenvolvimento:

\begin{abstract}
"Na África, até mesmo os observadores simpatizantes não podiam ignorar que a maioria dos estados do continente representava apenas uma paródia cruel do que eram as esperanças pós-coloniais. Os aparatos estatais inchados eram alvos óbvios para os latino-americanos tentarem compreender as raízes da estagnação escondida atrás da crise que os confrontava. [...] As burocracias governamentais foram consideradas estranguladoras do espírito empreendedor ou desviadas em atividades improdutivas de intermediação. Livrar-se delas era portanto o primeiro passo na agenda reformista. O abandono do Estado como um possível agente do desenvolvimento deixou como alternativa um pessimismo sem esperança ou 'uma fé no mercado' desprovida de qualquer crítica." (EVANS, 2004, p. 51).
\end{abstract}

Devo fazer ainda referência a duas correntes teóricas desenvolvidas mais recentemente. A primeira delas é a dos economistas que retomaram a antiga tradição institucionalista, desenvolvida por Polanyi e outros. A nova economia institucional retoma a idéia de que instituições importam e constituem um elemento essencial para compreensão do crescimento econômico das nações. A perspectiva neoinstitucionalista dialoga com algumas das críticas levantadas pela literatura de falhas de governo, em uma tentativa de resgatar ou minimizar os problemas da intervenção estatal. North, um dos principais expoentes dessa nova perspectiva, argumenta que as estruturas institucionais compõem a chave para compreensão do relativo sucesso de algumas economias, e considera alto o custo pela aceitação da premissa neoclássica de que a alocação de recursos ocorre num mundo sem atritos e instituições (EVANS, 2004, p. 63).

Um segundo grupo de autores traçou uma alternativa à tradicional abordagem neoclássica, partindo dos temas de inovação e da dinâmica evolucionária da economia. Esses teóricos resgatam as idéias de Schumpeter para se voltarem a uma nova compreensão do processo competitivo, em que a concorrência entre firmas não se limita à tentativa de maximização dos lucros, envolvendo também a necessidade de sobrevivência e constante adaptação através da inovação tecnológica. A analogia com processos biológicos de evolução e seleção natural é um recurso muito utilizado, embora de maneira flexível e sem determinismos. A teoria evolucionária tem seus principais antecedentes nos trabalhos de Alchian na década de 50 (ALCHIAN, 1950), atingindo a maturidade nas décadas de 
setenta em diante, com os trabalhos de Nelson, Winter e Dosi. No enfoque neoschumpeteriano, o papel do governo é mais uma vez afirmado, tendo como principal objetivo garantir a competitividade da economia e das empresas em termos sistêmicos.

O objetivo desse breve retrospecto foi situar temporalmente as principais correntes de teoria econômica que serão discutidas a seguir. Também abordei rapidamente a forma como cada uma delas identificou a relação Estado e economia, e os benefícios e problemas advindos dessa interação. Este debate constitui uma forte fundamentação teórica do tema da política industrial. Conforme os economistas admitam ou rechacem uma maior presença estatal na regulação e direcionamento dos agentes privados, a idéia de política industrial é consequentemente apoiada ou descartada. Por essa razão era importante situar seus marcos principais, ainda que de uma maneira simples. Os principais pontos e argumentos dessas teorias com relação ao Estado serão debatidos a seguir. Antes, no entanto, é importante fazer uma menção sobre o conceito e o debate sobre política industrial.

Conforme Chang, até algumas décadas atrás havia um certo consenso sobre a agenda deste debate, embora as divergências de entendimento sobre cada um de seus itens fossem bem intensas. Alguns desses temas eram a melhora na distribuição de renda, a estabilidade macroeconômica, o fornecimento de bens públicos e a regulação antitruste. A intervenção estatal na indústria era encarada com forte ceticismo, especialmente por não se enquadrar nos esquemas teóricos dominantes. Isto, obviamente, não significava que os governos não realizavam tal intervenção. Ao contrário, ela foi largamente utilizada durante o período pós-guerras no universo capitalista. (CHANG, 1996, P. 56).

O tema só chamou atenção para o debate teórico, entretanto, mais recentemente. $\mathrm{Na}$ Inglaterra a política industrial passa a ser debatida no final dos anos setenta com a introdução de programas intervencionistas de governo pelo partido trabalhista. O debate sobre desindustrialização nesse país também considerou a possibilidade de uma política industrial reverter esse processo, fornecendo novo vigor à economia inglesa. Nos anos oitenta, estudos discutiam as medidas tomadas por países europeus para contornar a crise econômica internacional da década anterior. (JOHNSON, 1984, p. ix).

Foi nos Estados Unidos, no entanto, que este tema foi mais intensamente debatido, especialmente na década de oitenta. $\mathrm{O}$ aparente declínio da posição competitiva deste país 
na economia mundial, a preocupação generalizada pela deterioração de indústrias básicas como a metalúrgica e a automobilística, e a dificuldade em manter a vanguarda tecnológica foram fatores que levantaram novas vozes, buscando rediscutir o papel do governo na vida econômica (JOHNSON, 1984, p. ix). Johnson identifica como uma das principais causas da enorme controvérsia gerada nos Estados Unidos em torno da política industrial o fato desta noção ter colocado em xeque vários dogmas que os norte-americanos antes tinham como inquestionáveis, e, mais do que isso, utilizavam para justificar seu poderio econômico, como o compromisso inquebrantável com os mecanismos de mercado como árbitro das decisões econômicas, a desconfiança mútua e conflito entre agentes públicos e privados (ao invés da cooperação), e a devoção ao livre comércio. (JOHNSON, 1984, p. 5).

Segundo este autor, a idéia contemporânea de política industrial foi inicialmente traçada pelos japoneses, embora suas raízes sejam de fato norte-americanas. No século XVIII, Hamilton expressou um importante princípio de política industrial, afirmando que os preços de mercado constituem excelentes indicadores para ajuste de oferta e demanda no curto prazo, mas são péssimos guias para decisões acerca de investimentos sobre novas tecnologias, produtos, e escalas de produção referentes a dez ou quinze anos à frente. (JOHNSON, 1984, p. 17).

Outra importante fonte do dirigismo japonês foram as idéias de List. Em meados do século XIX, este teórico formulou sua tese da indústria nascente ou infante (infant industry). List alegou que o livre comércio é benéfico entre países de nível semelhante de desenvolvimento industrial, mas não entre os que têm diferentes níveis de desenvolvimento. Neste caso, afirma, o intercâmbio internacional tenderia a desfavorecer fortemente as nações menos desenvolvidas. É por esse motivo, segundo o autor, que políticos e economistas britânicos da época atacavam as barreiras comerciais e alfandegárias. Sendo a Grã-Bretanha o grande país desenvolvido, deveria não só tirar proveito das trocas com as nações mais pobres como também impedir que outras se desenvolvessem (ou "chutar a escada", conforme Chang ${ }^{4}$ ).

Não parece haver na literatura muitas dúvidas sobre a larga utilização por países capitalistas de medidas das mais diversas para proteção e fomento de sua indústria e

\footnotetext{
${ }^{4}$ Para uma exposição mais detalhada do argumento de List ver CHANG, 2004.
} 
economia local. Entretanto, se cada caso deve ser considerado uma tentativa de política industrial vai depender da definição adotada, e aqui parece haver uma divergência teórica. Suzigan e Villela distinguem duas definições correntemente utilizadas na literatura. Em um primeiro contexto, política industrial é entendida sob uma perspectiva ampla, abrangendo não apenas medidas específicas e direcionadas como todo um amplo espectro de ações governamentais que afetem a produtividade e organização industrial. (SUZIGAN E VILLELA, 1997, pp. 15-16). Seguindo esta linha, Johnson define a política industrial como um conjunto de ações do governo destinadas a expandir ou retrair certos setores industriais da economia nacional, a fim de manter sua competitividade global. (JOHNSON, 1984, P. 7).

Neste sentido amplo, Johnson considera a idéia de política industrial, acima de tudo, uma "atitude", uma percepção de que todas as medidas governamentais trazem impactos no desenvolvimento dos setores econômicos e industriais. Seguindo esta linha, um país pode ter uma política industrial "negativa" (distorções, desestímulos e desigualdades) ou "positiva" (coordenação e iniciativa pública à produtividade e competitividade da economia e de determinados setores eleitos). É interessante destacar ainda que, para o autor, política industrial é uma decorrência lógica da noção de vantagem comparativa. No sentido clássico, esse termo teria significado diferenças geográficas e de recursos naturais responsáveis pela divisão internacional do trabalho. Já o novo conceito de vantagem comparativa inclui capital humano, visão, força de trabalho qualificada e educada, talentos organizacionais. Assim, esses atributos não são naturalmente fornecidos, mas representam o resultado de políticas públicas como educação, pesquisa e investimento em capital social. (JOHNSON, 1984, P. 8).

A lista do que seria incluído na idéia de política industrial sob essa perspectiva é grande, abrangendo medidas macro (incentivos públicos para poupança privada, investimento e pesquisa) e microeconômicas (seleção de setores a serem estimulados industrial targeting). Exatamente por esse motivo, autores como Chang criticam tais definições, por considerar que elas sobrecarregam o conceito, tornando-o amorfo e de pouca utilidade para o debate.

Seguindo essa crítica, uma perspectiva mais restrita de política industrial deve limitar o conjunto de medidas inseridas dentro desse conceito, excluindo expressamente os 
demais do objeto de análise. Conforme Suzigan e Villela, de acordo com essa abordagem a política industrial seria estritamente destinada a corrigir falhas de mercado ou melhorar sua operação. Chang, ao contrário, apresenta uma definição mais ligada a políticas seletivas para setores específicos: "nós propomos definir política industrial como uma política voltada a indústrias específicas (e às firmas que as compõem) para atingir resultados considerados pelo Estado como eficientes para a economia como um todo". (CHANG, 2004, p. 60, tradução nossa ${ }^{5}$.

Não cabe aqui questionar as vantagens e méritos dessas definições. Isso exigiria um debate teórico fora dos limites desta dissertação. Doravante, tentarei deixar claro em cada momento de qual "política industrial" estarei tratando, e como a expressão deve ser compreendida em cada contexto.

Concluída esta apresentação do debate, sigo apresentando como as principais escolas de pensamento econômico analisam o tema da política industrial. A esse respeito, noto que o debate, especialmente o brasileiro, parece ter se polarizado no embate entre neoclássicos e neoschumpeterianos, ou entre políticas horizontais e verticais. ${ }^{6}$ Apesar de entender que essa dicotomia é uma simplificação excessiva que pode prejudicar a análise do caso concreto brasileiro, seguirei parcialmente este esquema, como forma de estruturar mais claramente a exposição do debate.

\subsection{A escola neoclássica: política industrial e falhas de mercado}

Para compreender a concepção neoclássica de intervenção do Estado na economia e de política industrial a partir da teoria do bem-estar é necessário, inicialmente, saber o motivo pelo qual, de acordo com essa perspectiva, o mercado de concorrência perfeita e o livre comércio internacional são os melhores regimes e indicadores para a alocação eficiente dos recursos disponíveis.

\footnotetext{
5"We propose to define industrial policy as a policy aimed at particular industries (and firms as their components) to achieve the outcomes that are perceived by the state to be efficient for the economy as a whole". (CHANG, 2004, p. 60).

${ }^{6}$ Seguem essa divisão SUZIGAN e VILLELA, 1997; NASSIF, 2003; GARCIA e ROSELINO, 2004. No plano internacional Nelson e Winter também opõem essas duas tendências, embora seu trabalho esteja mais focado em crescimento econômico do que propriamente em política industrial. (NELSON E WINTER, 1974).
} 
Conforme mencionado, a teoria neoclássica do bem-estar é uma formalização do tradicional pensamento econômico de Smith e Ricardo, posteriormente aprofundado por Jevons, Menger, Walras, Mill e Marshall. A perspectiva neoclássica baseia-se em um conjunto de premissas e simplificações abstratas, que ajudam a compreender o comportamento dos agentes independente de outros fatores envolvidos, buscando em geral explicar a racionalidade e os resultados atingidos pelos indivíduos em suas ações. Conforme o grau de profundidade e complexidade, algumas das simplificações podem ser flexibilizadas. Há, no entanto, um conjunto central de premissas comum aos autores que utilizam esse ferramental teórico. As análises em geral são realizadas a partir de situações de equilíbrio estático, utilizando-se correntemente a estática comparativa (comparação entre dois estados de equilíbrio sem a preocupação de explicar como o mercado se move de um ponto para o outro).

O mercado, no contexto dessa teoria, perfaz um conceito abstrato, o "nome dado ao encontro de uma curva de oferta e de uma curva de demanda", resultante do comportamento de agentes cujas relações estão esvaziadas de qualquer conteúdo social. (STEINER, 2006, pp. 31-33). Isto equivale a dizer que esta teoria econômica se utiliza do mercado como instrumento teórico, para definir as características do comportamento racional, admitindo hipoteticamente uma situação em que esse comportamento possa se desenvolver sem entraves (ou instituições).

O mercado, como modelo de ambiente abstratamente construído, tem um correspondente humano, o indivíduo que atua nesse ambiente. Este é também uma construção teórica, o homo oeconomicus, cuja atuação segue um conjunto de regras. Isso leva a outro rígido conceito da teoria neoclássica, que é sua hipótese comportamental. $\mathrm{Na}$ teoria neoclássica, firmas e pessoas atuam conforme um conjunto de regras de decisão que dita como elas devem agir em face de certas condições (mercado, restrição orçamentária e estoque de capital disponível). O objetivo dessas decisões será sempre a maximização geralmente do lucro ou utilidade. (NELSON E WINTER, 2005, p. 29).

Além da maximização, o comportamento de agentes individuais e firmas segue ainda um outro padrão: a racionalidade plena (rational choice). Conforme Steiner, a teoria da escolha racional é o ponto de partida da teoria econômica moderna. A partir das escolhas (reais ou hipotéticas) dos agentes econômicos, seria possível inferir (ou criar) 
curvas de indiferenças, que constituem a base da teoria microeconômica do consumidor. (STEINER, 2006, p. 33). Segundo a premissa da racionalidade plena, os agentes possuem todo o conjunto de informações necessárias para a tomada de suas decisões, e, mais importante (e problemático), eles devem ser capazes de processar completamente essas informações (o que North chamou de "deciphering the environment").

A partir dessas premissas comportamentais e da hipótese de equilíbrio, a teoria neoclássica pode deduzir a idéia de eficiência e otimalidade de Pareto. Este seria o resultado ótimo naturalmente atingido nos mercados em que impera a concorrência perfeita, sendo este um outro conceito que depende de uma série de premissas, especialmente: um grande número de compradores e vendedores maximizadores e com racionalidade plena, sendo que nenhum deles tem poder para individualmente influenciar os preços (são "tomadores de preços"); os produtos são homogêneos, e seus preços os únicos indicadores para a tomada de decisões; não há barreiras à entrada ou à saída; todos os agentes têm informação perfeita; e os recursos e bens são resguardados por propriedade privada, eficientemente protegida pelo Estado. (MERCURO E MEDENA, 1997, p. 13$14)^{8}$

Considerando esse conjunto de proposições e uma dada dotação de fatores, poderse-ia provar que o resultado final das transações ocorridas é um "ótimo de Pareto", ou seja, os recursos e bens transacionados encontram-se alocados de uma forma tal que todos os agentes maximizam seu lucro ou utilidade. Uma vez que há informação perfeita e plena capacidade cognitiva, os agentes saberiam de antemão se houvesse alguma oportunidade de transação que pudesse melhorar sua situação (e como maximizadores concluiriam tal contrato). Num cenário de otimalidade paretiana não há espaço para qualquer realocação

\footnotetext{
${ }^{7}$ Citando Winter, North faz uma breve lista com as sete principais "assumptions" do modelo comportamental neoclássico: (i) o mundo econômico é visto como estando em equilíbrio; (ii) atores econômicos individuais repetidamente se deparam com as mesmas situações de escolhas ou seqüências muito similares; (iii) os atores têm preferências estáveis e, portanto, critérios estáveis de avaliação dos resultados de suas escolhas; (iv) dada essas repetições, cada ator individual é plenamente capaz de identificar e quantificar as oportunidades de aumentar seus resultados e, no caso de empresas, deverá necessariamente aproveitar essas chances sob pena de ser excluída através do processo competitivo; (v) a partir do acima, deduz-se que em uma situação de equilíbrio todos os atores individuais necessariamente maximizam suas preferências; (vi) uma vez que o mundo encontra-se em equilíbrio, os atores ao menos aproximadamente estão maximizando; (vii) embora os detalhes do processo adaptativo individual sejam complexos, as regularidades associadas com o equilíbrio maximizador são relativamente simples e de fácil observação. (NORTH, 1990, p. 19).

${ }^{8}$ Os autores fazem uma descrição gráfica para demonstrar a eficiência do modelo e ilustrar o conceito de otimalidade paretiana.
} 
de recursos (contrato, negociação) em que um agente aumente seu lucro ou sua utilidade, sem que isto signifique que outro saia perdendo com relação à posição anterior ${ }^{9}$.

No que tange aos investimentos empresariais e alocação de recursos pelas firmas, o mercado (conceitualmente estilizado) também seria o melhor árbitro. Não haveria, assim, no modelo de concorrência perfeita, qualquer problema ou necessidade de uma coordenação ex ante. Considerando que as firmas têm por premissa comportamental a maximização de seus lucros, elas sempre buscarão investir em setores que lhes garantam maior rentabilidade, equalizando o retorno e levando o mercado ao equilíbrio. Conforme Mercuro e Medema, satisfeitas as condições da concorrência perfeita, o custo social marginal será equivalente ao benefício social marginal para todo e qualquer produto ali ofertado, o que equivale a um ponto ótimo de pareto (esta afirmação é demonstrada fazendo recurso a um modelo matemático e gráfico - a Caixa de Edgeworth). (MERCURO E MEDEMA, 1997, p. 16).

Não há, portanto, no modelo de mercado perfeitamente competitivo, qualquer espaço para a atuação estatal, exceto aquelas mínimas tarefas previstas pelo modelo (garantia de direitos de propriedade e da execução dos contratos), que garantam o funcionamento do mercado. A estrutura jurídica corresponde à legislação do Estado liberal do século XIX, essencialmente destinada à garantia da propriedade privada e da liberdade $\mathrm{e}$ enforcement contratual, sem qualquer direcionamento ou intervenção no funcionamento dos mercados. As decisões de investimento seriam totalmente tomadas pelos agentes privados, inspiradas pelos sinais e informações recebidas, especialmente o sistema de preços.

No plano internacional, a teoria das vantagens comparativas, inicialmente desenvolvida por Ricardo, reafirma o argumento contra a intervenção estatal. Conforme esta teoria, uma nação estará sempre melhor, no sentido de ser beneficiada com maior produção (output), se concentrar seus esforços em atividades e setores nos quais seus custos de produção sejam relativamente mais baratos, comparados com outros países. E para se chegar às vantagens comparativas de cada país, deve-se deixar os preços dos produtos internacionais flutuarem livremente no mercado interno, sem qualquer

\footnotetext{
${ }^{9}$ Nessa idéia, um novo equilíbrio em que os dois (ou mais) agentes melhorassem concomitantemente sua situação seria um ponto pareto-superior (pareto improving).
} 
intervenção governamental. Assim, será possível identificar quais os bens e serviços nacionais possuem preços efetivamente competitivos, (WADE, 1990, p. 14), deixando aos empresários privados a tarefa de investirem nesses ramos para obtenção do maior lucro. Por esse motivo, na perspectiva neoclássica a eficiência no mercado internacional é outro elemento que demanda o livre comércio e a baixa intervenção do Estado.

Nassif resume os argumentos da literatura neoclássica expostos afirmando:

\begin{abstract}
“A literatura neoclássica sobre proteção (ou outras justificativas para políticas de intervenção governamental no livre funcionamento dos mercados) está assentada na proposição inicial de que, sob a hipótese de concorrência perfeita em todos os mercados e de inexistência de qualquer tipo de tarifa, subvenção ou outras formas de intervenção estatal, os regimes de laissez-faire e de livre-comércio assegurariam o máximo bem-estar social no sentido de Pareto (first-best). Sob essa hipótese, intervenções estatais na alocação de recursos seriam contraproducentes, porque afastariam a economia de seu resultado ótimo." (NASSIF, 2003, p. 8).
\end{abstract}

Como mencionado, a partir da década de 50 alguns autores passaram a flexibilizar algumas das rígidas premissas constantes do modelo neoclássico, no sentido de reconhecer que, em diversas circunstâncias, os mercados reais se afastam do modelo teórico de concorrência perfeita. Nesses casos, alguma forma de intervenção governamental seria desejável, a fim de sanar essas falhas e aproximar a alocação de recursos de seu nível ideal. Segundo Chang, a literatura das falhas de mercado é atualmente a mais avançada no tema da intervenção do Estado. Sua principal preocupação é com a incapacidade dos mecanismos de mercado em igualar os benefícios e custos privados e sociais, e com a possível correção de tais falhas através de políticas públicas. (CHANG, 1996, p. 7).

O termo falha de mercado (market failure) remete a uma situação em que o mercado não funciona da forma como o idealmente esperado. Há um rico debate sobre o que seria esse "mercado ideal", o que ele deveria fazer e o que poderia representar uma falha ${ }^{10}$. Mas, no contexto da ortodoxia neoclássica, uma falha de mercado seria a ocorrência de determinada circunstância que afasta a economia real do modelo de concorrência perfeita. Arrow e Debreu identificaram algumas dessas circunstâncias, que atualmente são reconhecidas como as tradicionais falhas de mercado na teoria do bemestar. São elas: a presença de bens públicos ${ }^{11}$, externalidades ${ }^{12}$ ou mercados não

\footnotetext{
${ }^{10}$ Para um aprofundamento nesse debate ver CHANG, 2000, p. 12.

11 Ao contrário do conceito jurídico, a idéia de bens públicos em economia relaciona-se às idéias de
} 
competitivos $^{13}$. (STIGLITZ, 1996, p. 155). O desenvolvimento posterior da teoria identificou e formalizou no modelo outras falhas de mercado, que poderiam ou não ser corrigidas pela ação governamental. Dentre essas novas falhas encontram-se a informação imperfeita ou assimétrica, mudanças na tecnologia e externalidades de rede.

Percebe-se que, apesar de constituir um notável avanço, a literatura das falhas de mercado não se afastou de pilares fundamentais da teoria neoclássica, como a confiança nos mecanismos de mercado como os melhores indicadores para a alocação de recursos e investimentos empresariais. Toda a idéia de "correção" dessas falhas tem por único objetivo restaurar ou instituir a concorrência perfeita, ou ainda simular seus resultados em termos de preço e quantidade, levando a economia à produção tida por socialmente ótima.

Qual seria o papel de uma política industrial nessa perspectiva? Não faria sentido falar aqui em indução ou promoção estatal de um setor. Sendo o mercado o melhor árbitro dos investimentos a serem realizados, basta ao governo garantir o ambiente de concorrência perfeita. Qualquer intervenção nos incentivos ou resultados (pay-offs) a serem recebidos pelos agentes representaria uma distorção e uma utilização ineficiente de recursos, que poderiam ser melhor aplicados se seguissem as vantagens comparativas inicialmente dadas.

Por esse motivo, na perspectiva neoclássica a política industrial perpetrada pelo Estado é, geralmente, de tipo horizontal, ou seja, atinge potencialmente todos os setores da

rivalidade e exclusão. O bem público pode ser utilizado por quem arcou com seus custos e também por outras pessoas, não apenas porque esse bem é não-rival (o uso por um indivíduo não impede o uso por outros), mas também porque não é economicamente viável excluir os não pagadores - o bem é não-excludente. Exemplos de bens públicos seriam a iluminação pública e o serviço de limpeza de vias urbanas. O problema econômico do bem público é que ele gera para cada um dos agentes o incentivo individual de não incorrer nos custos de seu fornecimento. Neste caso, a racionalidade individual acaba levando à irracionalidade coletiva. Uma vez que todos os agentes tentarão individualmente maximizar seus benefícios pagando o mínimo possível, a coletividade como um todo acabará produzindo o bem em quantidade inferior à socialmente demandada. (CHANG, 1996, p. 8).

${ }^{12}$ A presença de externalidades diz respeito a um descompasso entre custos e resultados privados de uma determinada atividade. Aqui há transbordamentos (spillovers) do que um indivíduo faz para outros agentes, sejam esses efeitos positivos ou negativos. Os casos tradicionais de externalidade negativa são o da fábrica poluidora e a poluição de automóveis. (CHANG, 1996, p. 10).

${ }^{13}$ Mercados não competitivos são aqueles nos quais, por alguma razão (como economias de escalas ou colusão), as ações de agentes individuais podem afetar a estrutura de preços vigente, ou seja, esses agentes não são "tomadores de preços". São os casos em que há uma estrutura de monopólio ou oligopólio. O ferramental teórico neoclássico vai argumentar que, nessas situações, os produtores conseguem auferir lucros monopolistas (devido a uma curva de demanda negativamente inclinada); os preços são mais altos e a quantidade produzida inferior, tendo por parâmetro de comparação o mercado competitivo. (CHANG, 1996, p. 9). 
economia. Nesta abordagem os incentivos públicos devem se pautar pela neutralidade. A atuação estatal não deve beneficiar algum setor específico (política vertical), pois isso poderia levar a um investimento excessivo. Políticas do tipo horizontal admitidas pelo pensamento econômico tradicional seriam, por exemplo, políticas que enfocam a redução do chamado custo-país e aprimoramento permanente do sistema de infra-estrutura física e humana. (NASSIF, 2003, p. 7). Sob uma ótica jurídica, essas políticas incluem reformulações no sistema tributário e judiciário, a fim de aprimorar a segurança jurídica, o enforcement de contratos e obrigações, a previsibilidade de decisões, e a redução de custos de transação.

O direito, nesta perspectiva, cumpre um papel instrumental, no sentido de estabelecer ou impor instrumentos que superem essas falhas, para o aumento da eficiência ou bem-estar na economia. Assim, no caso de bens públicos, o Estado poderá exigir que todos os beneficiados paguem pelo fornecimento do bem (sendo o método tradicional a tributação), evitando o sub-investimento e garantindo a produção. Já na presença de externalidades, poderão ser utilizadas técnicas que equalizem os benefícios e custos sociais e privados, como o subsídio ou fornecimento público em caso de externalidades positivas (educação, saúde, infra-estrutura), ou a tributação em caso de externalidades negativas. Nos mercados não competitivos, o Estado intervém para garantir uma produção ótima, ou ainda para impedir a emergência dessa organização industrial, especialmente através da regulação da concorrência (legislação antitruste), ou da propriedade estatal de setores econômicos sujeitos a fortes barreiras de entrada e economias de escala.

\section{$1.3 \mathrm{O}$ neo-utilitarismo e a literatura de falhas de governo}

A partir dos anos setenta, um conjunto de idéias e novos trabalhos voltou a atacar a efetividade da intervenção estatal na economia. Reafirmou-se a confiança nos mecanismos de mercado, levantando-se a dúvida acerca da capacidade do Estado em corrigir as falhas identificadas pela teoria. O neoliberalismo (ou neo-utilitarismo, conforme Evans) trouxe novas percepções de como encarar a atividade governamental e suas conseqüências. Essas teorias ganharam amplo espaço nos anos que se seguiram, muito em parte por refletir a percepção de aparatos burocráticos lentos, custosos e pouco eficazes em países em desenvolvimento. 
Segundo Evans, o neoliberalismo não trouxe uma grande novidade intelectual. Em grande parte tratava-se apenas do retorno à confiança quase plena no mercado. Esta nova formulação, todavia, trazia consigo um considerável suporte teórico e formal analítico para suas prescrições. A economia neoclássica anterior reconhecia a importância do Estado, desde que limitado as suas funções mínimas. Nesse modelo, o funcionamento da máquina pública era explicado através de suposições e premissas, sem uma verificação empírica ou questionamento mais detalhados. Os neo-utilitaristas, ao contrário, conferiram grande relevância à análise das conseqüências negativas da ação do Estado. Para isso aplicaram as ferramentas de maximização individual da microeconomia ao Estado e aos indivíduos que o compõem. (EVANS, 2004, p. 52).

A ascensão do neoliberalismo alterou substancialmente as bases do debate sobre o papel do Estado. Conforme Chang, o aparelho governamental deixou de ser identificado como um "guardião" imparcial e onipotente, passando a ser visto como um "predador", ou um instrumento para grupos politicamente mais fortes obterem vantagens e privilégios. Neste novo viés, burocratas e políticos não são movidos por espírito público, como se considerava anteriormente, mas pela busca de maximização de seus próprios interesses. (CHANG, 2000, p. 3).

Uma vez que o Estado e seus agentes não possuem interesse ou capacidade em agir coordenada e coerentemente para corrigir falhas de mercado, volta-se à condenação da intervenção estatal, ou ao menos à postura cética quanto a seus efeitos positivos. Para reduzir os seus efeitos deletérios, a esfera de atuação do Estado deveria ser reduzida ao mínimo, e o controle burocrático substituído por mecanismos de mercado sempre que possível. Em uma extensa revisão da literatura mais atual que ataca a intervenção estatal, Chang divide essas teorias em dois ramos: a economia política, que indaga sobre a "intenção" ou objetivo da ação; e a literatura das falhas de governo, que questiona a capacidade dos agentes públicos em realizar tal intervenção. (CHANG, 1994, p. 18-31). Não sendo meu objetivo realizar uma revisão extensa dessa literatura, tentei sintetizar os principais pontos e críticas levantados por Chang, em um breve resumo esquemático que me permita utilizar essas idéias de forma prática e adequada nos demais capítulos. 


\begin{tabular}{|c|c|c|c|c|}
\hline $\begin{array}{c}\text { Literatura/ } \\
\text { Escola de } \\
\text { pensamento }\end{array}$ & $\begin{array}{c}\text { Principais } \\
\text { questões/objetivos } \\
\text { levantados }\end{array}$ & $\begin{array}{l}\text { Subdivi- } \\
\text { sões/ } \\
\text { temas } \\
\end{array}$ & Principal argumento & Críticas \\
\hline \multirow{3}{*}{$\begin{array}{l}\text { Economia } \\
\text { Política }\end{array}$} & \multirow{3}{*}{$\begin{array}{l}\text { Critica a idéia de } \\
\text { que o Estado (ou } \\
\text { seus funcionários) } \\
\text { constitui um árbitro } \\
\text { neutro e imparcial, } \\
\text { e que suas ações } \\
\text { sempre visam à } \\
\text { promoção do bem } \\
\text { comum. }\end{array}$} & $\begin{array}{l}\text { Teoria do } \\
\text { Estado- } \\
\text { Autônomo }\end{array}$ & $\begin{array}{l}\text { Estado como "força autônoma independente", } \\
\text { que sempre tenta maximizar sua receita líquida. }\end{array}$ & $\begin{array}{l}\text { Simplificação e tratamento do } \\
\text { Estado como um ente } \\
\text { uniforme, cujos diversos } \\
\text { órgãos e agentes agiriam } \\
\text { conjunta e coerentemente. } \\
\text { Não ajuda a entender } \\
\text { problemas concretos. }\end{array}$ \\
\hline & & $\begin{array}{l}\text { Interest- } \\
\text { group } \\
\text { approach }\end{array}$ & $\begin{array}{l}\text { Identifica o Estado como uma arena na qual } \\
\text { grupos, classes ou movimentos sociais lutam ou } \\
\text { se aliam para determinar o conteúdo das } \\
\text { decisões e a alocação de recursos e benefícios. } \\
\text { "Captura regulatória" (escola de Chicago) - } \\
\text { produtores (ou a indústria) constituem grupo } \\
\text { menor, o que facilita a ação coordenada e a } \\
\text { superação do problema da ação coletiva. Agem } \\
\text { para manipular a regulação, que seria elaborada } \\
\text { e defenderia principalmente os seus interesses. }\end{array}$ & $\begin{array}{l}\text { Negligencia/não discute } \\
\text { adequadamente o problema da } \\
\text { ação coletiva. } \\
\text { Não explica o processo político } \\
\text { de formação de interesses e } \\
\text { seus resultados. }\end{array}$ \\
\hline & & $\begin{array}{l}\text { Self- } \\
\text { seeking } \\
\text { bureau- } \\
\text { crats }\end{array}$ & $\begin{array}{l}\text { Burocratas e funcionários públicos são } \\
\text { igualados a agentes privados } \\
\text { deriva do valor de seus salários e do prestígio de } \\
\text { suas repartições (budget-maximizers). } \\
\text { Assimetria informacional coloca corpo } \\
\text { burocrático em vantagem com relação a } \\
\text { políticos eleitos. }\end{array}$ & $\begin{array}{l}\text { Expansão de repartições é } \\
\text { limitada e está sujeita a } \\
\text { processos políticos } \quad \text { e } \\
\text { institucionais estabelecidos } \\
\text { (ex. concurso público). } \\
\text { Burocratas também pautam } \\
\text { suas ações por outros valores } \\
\text { ("public spiritedness"). }\end{array}$ \\
\hline \multirow{2}{*}{$\begin{array}{l}\text { Falhas de } \\
\text { governo } \\
\text { (government } \\
\text {-failure } \\
\text { literature) }\end{array}$} & \multirow{2}{*}{$\begin{array}{l}\text { Argumenta que, } \\
\text { mesmo que o } \\
\text { Estado tenha a } \\
\text { intenção e o } \\
\text { objetivo de realizar } \\
\text { políticas com } \\
\text { resultados positivos, } \\
\text { ele não conseguirá } \\
\text { realizá-las. }\end{array}$} & $\begin{array}{l}\text { Problema } \\
\text { informa- } \\
\text { cional }\end{array}$ & $\begin{array}{l}\text { Flexibiliza a premissa da informação perfeita do } \\
\text { ente estatal. } \\
\text { Para formular uma política econômica } \\
\text { adequada, o Estado precisa suprir déficit de } \\
\text { informação. Devido ao grande volume de } \\
\text { informações necessárias, o custo desse processo } \\
\text { torna-se proibitivo. } \\
\text { Problema "agente-principal". } \\
\text { Racionalidade limitada (bounded rationality). }\end{array}$ & $\begin{array}{l}\text { Problema tende a ser } \\
\text { exagerado. Empresas privadas } \\
\text { sofrem o mesmo problema. } \\
\text { Organizações públicas e } \\
\text { privadas têm, paulatinamente, } \\
\text { encontrado soluções para } \\
\text { mitigar essas questões. }\end{array}$ \\
\hline & & $\begin{array}{l}\text { Rent- } \\
\text { Seeking }\end{array}$ & $\begin{array}{l}\text { Intervenção estatal causa ineficiência ao alterar } \\
\text { os ganhos e lucros de determinadas atividades. } \\
\text { Agentes privados são direcionados para o } \\
\text { exercício de atividades menos produtivas. } \\
\text { "Renda" - parte do pagamento ou lucro recebido } \\
\text { em excesso ao que tais recursos poderiam gerar } \\
\text { se utilizados alternativamente em outra } \\
\text { atividade. }\end{array}$ & $\begin{array}{l}\text { Natureza dos custos de rent- } \\
\text { seeking não é claramente } \\
\text { definida. Atividades tidas por } \\
\text { improdutivas podem gerar } \\
\text { efeitos positivos. } \\
\text { Intervenção pode ser } \\
\text { necessária para sustentar } \\
\text { ambiente competitivo. } \\
\text { Rent-seeking pode ser } \\
\text { produtivo indiretamente } \\
\text { ganhos dinâmicos. }\end{array}$ \\
\hline
\end{tabular}

Após essa breve revisão das principais idéias, retomo a importância do neoutilitarismo e da literatura citada para o tema da intervenção estatal e política industrial. Essas idéias certamente podem ser consideradas um avanço, no sentido de que lançaram novas luzes na análise e forma de abordar o funcionamento do Estado. Algumas premissas excessivamente simplificadoras da teoria neoclássica certamente deixaram de ser tomadas como certas. Estudiosos e formuladores de políticas passaram a considerar a possibilidade do Estado não agir como um ente homogêneo, desinteressado e plenamente hábil a desempenhar suas funções. Conforme Chang, “o viés 'minimalista' resultante nos termos desse debate significa que aqueles que desejam argumentar a favor da intervenção estatal

\footnotetext{
${ }^{14}$ Para outras referências sobre este debate ver EVANS, 1993, e ARVATE E BIDERMAN, 2006.
} 
precisam combater seus adversários em cada um de seus argumentos, quaisquer que sejam seus méritos [...]". (CHANG, 2000, p. 4, tradução nossa) ${ }^{15}$

No que toca à questão da política industrial, a emergência dessa nova visão significou um retrocesso, no sentido de uma volta ao conjunto de prescrições políticas que eram feitas anteriormente às teorias de falhas de mercado. O Estado não só não dispõe de informações e recursos (ou mesmo interesse) para corrigi-las, como suas ações podem acabar trazendo uma ineficiência ainda maior, através do estímulo ao rent-seeking. Dentro desse quadro teórico não haveria espaço para uma política industrial, ainda que de viés horizontal.

A confiança nos mecanismos de mercado para provisão de bens e serviços foi amplamente retomada, com a pregação do desmantelamento do aparato governamental para planejamento e intervenção econômica. Conforme relata Evans, as proposições de mercantilização ou privatização das funções estatais chegaram ao ponto de serem sugeridos prêmios ou remunerações para mercenários ou cidadãos que se dedicassem lucrativamente à atividade de defesa nacional, ao invés das forças armadas organizadas. (EVANS, 2004, p. 52). No que se refere ao papel do direito dentro desse arcabouço teórico, trata-se exatamente do que David Kennedy identificou como o terceiro momento das idéias sobre desenvolvimento - o "Consenso de Washington"16. A proposta para a estrutura jurídica dentro do neo-utilitarismo seria o desmonte dos aparatos protecionistas do período anterior. A pedra de toque é a proteção dos direitos privados, devendo a lei estabelecer claramente os direitos de propriedade e garantir a segurança jurídica e a limitação da ação do Estado. Não há espaço, assim, para quaisquer instrumentos ou ferramentas jurídicas, seja para promover o desenvolvimento industrial ou corrigir falhas de mercado.

O neo-utilitarismo e a literatura de falhas de governo foram posteriormente criticadas, dentre outros, pelos teóricos da chamada Nova Economia Institucional. A relevância e influência dessas idéias permaneceram, embora suavizadas de sua rigidez. Elas forneceram um excelente arcabouço teórico para explicar estados que pouco agregam

\footnotetext{
15 "The resulting 'minimalist' bias in the terms of debate means that those who want to make a case for state intervention have to fight their adversaries at each and every step of their arguments, whatever the merits of their arguments may be [...]". (CHANG, 2000, p. 4).

${ }^{16}$ Ver em minhas Considerações Iniciais.
} 
ao bem-estar social de suas populações, e como pode ser difícil e custoso implementar uma política pública.

\subsection{A defesa da política industrial: a escola evolucionária}

A necessidade de uma abordagem alternativa que tente pensar a importância do Estado surge a partir de uma aparente contradição entre, de um lado, o discurso da tradicional teoria do bem-estar e do neo-utilitarismo e, de outro, a prática e a tendência empiricamente verificada sobre esse tópico.

Tais arcabouços teóricos, conforme até aqui exposto, possuem uma forte aversão à atuação estatal. Seja como o mero Estado policial da teoria econômica do século XIX ou como corretor das falhas de mercado, o resultado permanece sendo governos com um papel bem limitado na realidade econômica. E isto porque, acima de tudo, quem melhor promove o crescimento e distribuição eficiente de recursos são os mecanismos de mercado, e não as deliberações e vontades políticas. Considerando essas prescrições, o resultado ou conclusão lógica a que se chega é a de que os países mais bem sucedidos seriam aqueles com uma burocracia relativamente enxuta, e que, ao contrário, nações dotadas de grandes aparatos públicos apresentariam sérios problemas econômicos a serem superados.

Esse diagnóstico, entretanto, parece francamente contrário ao que vem ocorrendo nas últimas décadas, inclusive em países desenvolvidos. Tanto estados quanto burocracias continuam a crescer, e a desempenhar uma importância fundamental na economia. Mesmo alguns representantes de instituições tradicionalmente conservadoras, como o Banco Mundial e o Fundo Monetário Internacional, passaram recentemente a defender ou ao menos admitir a importância de um papel ativista do governo no desenvolvimento industrial. (EVANS, 2004, p. 49).

Um importante evento que alterou substancialmente os termos deste debate foi o exuberante crescimento dos países do sudeste asiático. O East Asian Miracle como ficou conhecido, contou com uma estratégia desenvolvimentista que tinha um forte envolvimento estatal. Diversos economistas e instituições debruçaram-se sobre o tema, em uma tentativa de compreender de que forma essas nações atingiram níveis tão elevados de 
desenvolvimento industrial com aparatos públicos tão intervencionistas e com relações fortes com o empresariado ${ }^{17}$.

Apenas a título argumentativo, uma leitura neoclássica caricaturizada e simplificadora desses eventos tentaria demonstrar que o aumento do envolvimento estatal seria ou o resultado de uma expansão cumulativa de falhas de mercado, ou uma evidência significativa de que essas economias deveriam padecer de uma erosão crescente. A análise empírica, todavia, não parece confirmar nenhuma dessas hipóteses. Nesse sentido expressa Burlamaqui:

\begin{abstract}
"[...]então governos maiores e burocracias crescentes devem causar inevitavelmente a deterioração da performance do sistema. Se esta abordagem é aceita, claramente tanto a 'era dourada' do capitalismo após a segunda guerra mundial quanto a explosão de desenvolvimento do leste asiático dos anos setenta até outubro de 1997 não se encaixam nesta hipótese.” (BURLAMAQUI, 2000, p. 29 , tradução nossa). ${ }^{18}$
\end{abstract}

O descompasso entre a ortodoxia neoclássica e tais desenvolvimentos da segunda metade do século XX passou a exigir o recurso a outras fundamentações, que tentassem explicar como os estados poderiam, ao menos em alguns casos, ter uma agenda positiva e colaborar para o progresso da economia. A abordagem evolucionária ou neoschumpeteriana cumpriu este papel, apresentando uma alternativa embasada em sólida argumentação teórica e forte crítica à visão neoclássica.

Tomando arbitrariamente alguns pilares fundamentais da teoria evolucionária, pode-se afirmar que seu desenvolvimento parte de uma analogia não rígida com fenômenos e teorizações do campo da biologia, uma perspectiva diferente das premissas comportamentais das empresas e da declarada herança schumpeteriana. A identificação com processos biológicos revela-se já na adoção do termo 'evolucionário'. Conforme Nelson e Winter, "trata-se, acima de tudo, de uma sinalização de que tomamos emprestadas idéias básicas da biologia [...].” (NELSON E WINTER, 2005, p. 26). Tratar questões econômicas através de uma perspectiva evolucionária e biológica apenas faz sentido se identificarmos na economia (assim como uma evolução de organismos e seus

\footnotetext{
${ }^{17}$ A esse respeito ver BANCO MUNDIAL, 1993, e PACK, 2006.

18 “'...] so, bigger governments and growing bureaucracies should inevitably cause the system's performance to deteriorate. If this kind of approach is accepted, both the 'golden age' of capitalism after the Second World War and even more so the East Asian development explosion from the seventies through October 1997 clearly do not fit in with this hypothesis". (BURLAMAQUI, 2000, p. 29).
} 
ambientes) um processo dinâmico, envolvendo mudanças e cenários progressivos no longo prazo.

Assim como na biologia, a idéia de "seleção natural" aqui se faz de enorme relevância. No caso econômico, entretanto, são os ambientes de mercado que oferecem uma definição de sucesso para as firmas, e essa definição está muito próxima à habilidade delas de sobreviver e crescer. As empresas, neste modelo, são dotadas de rotinas e regras de decisão que se diferenciam entre si (uma representação simbólica da idéia de "genes"), e a partir dessas diferenças e dos estímulos recebidos do ambiente externo (o mercado), cada empresa traça seus planos quanto a investimentos, pesquisas e relações comerciais diversas, e essas decisões irão definir suas chances de sucesso nos próximos estágios, assim como colaboram para traçar o próprio cenário em que irão atuar (em uma relação de retro-alimentação).

O recurso à analogia interdisciplinar, entretanto, é limitado. A teoria evolucionária utiliza a biologia apenas naquilo que entende similar ou útil para explicar o funcionamento da economia, não se prendendo a uma rígida comparação até as últimas conseqüências. Conforme Nelson e Winter:

\footnotetext{
"temos satisfação em explorar qualquer idéia da biologia que pareça útil para a compreensão de problemas econômicos, mas estamos igualmente preparados para ignorar qualquer coisa que pareça estranha, ou para modificar radicalmente teorias biológicas aceitas em prol do desenvolvimento de uma melhor teoria econômica". (NELSON E WINTER, 2005, p. 28).
}

O melhor exemplo desse desapego é a aceitação de que firmas e agentes podem adquirir e aceitar novas "características" (suas rotinas decisórias), dados os estímulos e adversidades impostos pelo ambiente, utilizando para isso processos de busca, pesquisa e desenvolvimento deliberados. E essas características são transmissíveis, contemplando a "herança genética" das firmas, em um processo mutacionista tipicamente lamarckiano.

Uma das peculiaridades que caracterizam a teoria evolucionária é sua interpretação do comportamento das firmas. Neste modelo não se tenta prever ou predizer como as empresas deverão agir a partir de uma regra teórica de decisão. O objetivo neste ponto é contestar a premissa maximizadora neoclássica como único elemento explicativo do comportamento empresarial. Conforme Nelson e Winter, "O maior compromisso da teoria 
evolucionária é a abordagem 'comportamental' das firmas individuais. [...] enquanto a teoria neoclássica tenta deduzir essas regras de decisão a partir da maximização, a teoria comportamental apenas as toma como dadas e observáveis." (NELSON E WINTER, 1974, p. 891, tradução nossa ${ }^{19}$ ). E ainda: "nós aderimos à visão ortodoxa de que o lucro é o principal componente motivacional; entretanto, a lógica evolucionária é igualmente consistente com uma ênfase 'gerencialista' do crescimento ou da 'vida tranqüila"'. (NELSON E WINTER, 1974, p. 892, tradução nossa ${ }^{20}$ ).

As regras de decisão e as rotinas empresariais (definidas como padrões comportamentais regulares e previsíveis) representam um conceito operacional básico na teoria evolucionária. Não são tomadas como premissas teoricamente traçadas, mas, ao contrário, observadas e aceitas em sua complexidade. São as diferentes rotinas que, em última análise, se defrontam na concorrência e processo de seleção, e esse confronto vai estabelecer as oportunidades e probabilidades de sucesso das empresas nos próximos estágios.

Esses dois elementos já se encontravam mencionados e faziam parte (ainda que não plenamente desenvolvidos) do pensamento de Schumpeter, que inspirou e forneceu a base sobre a qual se construiu a teoria evolucionária contemporânea. As idéias de Schumpeter, especialmente aquelas expostas em suas três principais obras - Teoria do Desenvolvimento Econômico (1912, reeditado em 1934); Ciclo dos Negócios (1939); e Capitalismo, Socialismo e Democracia (1942) - permeiam grande parte da construção teórica evolucionária. A analogia com as ciências biológicas já estava presente no primeiro trabalho citado, quando a economia estacionária (o modelo de equilíbrio descrito no primeiro capítulo) é apresentada como um fluxo circulatório na forma de analogia com um organismo. (CRUZ, 1988, p. 434). Também a idéia do comportamento racional maximizador é colocada de lado quando o autor tenta explicar o surgimento da inovação, fenômeno fundamental do desenvolvimento econômico que rompe com o equilíbrio do fluxo circulatório. Conforme Cruz, "o agente que conduz as inovações recebe o nome de

\footnotetext{
19 "the major commitment of the evolucionary theory is to a 'behavioural' approach to individual firms.(...) While neoclassical theory would attempt to deduce these decision rules from maximization on the part of the firm, the behavioural theory simply takes them as given and observable". (NELSON E WINTER, 1974, p. $891)$.

20 "we adhere to the orthodox view that some form of the profit motive is the dominant motivational consideration; however, the logic of the evolutionary approach is equally consistent with a 'managerialist' emphasis on growth or "the quiet life"'. (NELSON E WINTER, 1974, p. 892).
} 
empresário. Esta figura distingue-se do homo economicus do fluxo circulatório [...]. O autor utiliza termos como liderança, ousadia, aventura, desejo de conquistar alegria de criar para descrevê-lo". (CRUZ, 1988, p. 435).

Um ponto central para a compreensão da análise schumpeteriana (e dos modelos evolucionários) é a percepção do autor sobre o capitalismo e o processo concorrencial. Em Capitalismo, Socialismo e Democracia, Schumpeter destacou a idéia de que o capitalismo não pode ser compreendido como um momento estacionário, sendo na verdade um processo evolucionário. (SCHUMPETER, 1942, p. 82). De acordo com Cruz, Schumpeter adotou um conceito de competição muito mais rico que os neoclássicos. Enquanto para estes a competição limita-se a preços e quantidades, em Schumpeter este fenômeno envolve necessariamente a mudança técnica, as variações de qualidade, e os esforços de vendas. A inovação torna-se assim elemento interno do sistema econômico, transformando-se no motor de sua evolução. (CRUZ, 1988, p. 444). Esse processo de "destruição criadora" é um fato essencial sobre o capitalismo. E a partir desse paradigma Schumpeter questiona a idéia de que uma estratégia ou alocação de recursos possa ser considerada ótima se levado em conta apenas o momento estacionário.

\footnotetext{
"Um sistema, qualquer sistema, seja econômico ou outro, que a todo instante aproveita plenamente suas possibilidades para as melhores vantagens pode no longo prazo ser inferior a um sistema que não cumpre o mesmo em nenhum momento, porque o fracasso nessa tarefa pode ser uma condição indispensável para o nível ou velocidade de desempenho no longo prazo.", SCHUMPETER, 1942 , p. 83 , tradução nossa). ${ }^{21}$
}

A inovação é conceituada por Schumpeter como abrangendo cinco grandes grupos: um novo bem ou produto; um novo método de produção; a abertura de um novo mercado; a conquista de uma nova fonte de suprimento de matérias-primas ou produtos semiindustrializados; e uma nova organização industrial. (SCHUMPETER, 1934, p. 93). Este é o principal componente ou combustível da "destruição criadora" ou da concorrência schumpeteriana, que rompe o equilíbrio estático e introduz a incerteza no processo evolucionário. Depende, entretanto, de uma série de condições para sua efetivação, como a figura do empreendedor e um volume de crédito disponível.

\footnotetext{
21 "A system - any system, economic or other - that at every given point of time fully utilizes its possibilities to the best advantage may yet in the long run be inferior to a system that does so at no given point of time, because the latter's failure to do so may be a condition for the level or speed of long-run performance". (SCHUMPETER, 1942, p. 83).
} 
Através da inovação, o empreendedor se torna por tempo limitado um monopolista, capaz de auferir lucros que seus concorrentes não atingem. O período de monopólio é variável, e pode ser influenciado pela estrutura institucional vigente (como o sistema de patentes). Com o tempo, porém, a inovação vai se incorporando ao sistema através dos seguidores ou imitadores, em um processo que pode levar à ascensão e decadência das diversas firmas envolvidas.

Na perspectiva da concorrência schumpeteriana pode não fazer sentido destacar uma interferência estatal com o estrito objetivo de construir a concorrência perfeita (correção de falhas de mercado). O exemplo principal aqui é o da concentração industrial ou políticas anti-truste. Enquanto na abordagem neoclássica o argumento da otimalidade paretiana pode justificar uma política para manter os mercados perfeitamente competitivos, no modelo evolucionário isso poderia representar um desestímulo à inovação, sendo dessa forma ineficiente no longo prazo (esta, entretanto, não é uma regra geral).

Assim, políticas públicas com um viés mais intervencionista podem fazer um grande sentido e trazer eficiência ao sistema nessa abordagem. Conforme Burlamaqui, no cenário concebido pela teoria neoschumpeteriana, onde finanças, tecnologia e concorrência estão constantemente apontando para resultados inesperados e imprevisíveis, políticas públicas que colaboram para a transformação industrial são uma permanente necessidade ditada pelo próprio comportamento do mercado (e não por suas falhas). (BURLAMAQUI, 2000, p. 43).

E por isso a abordagem evolucionária aceita ou recomenda que, quando apropriado, o Estado lance mão de políticas seletivas ou verticais. Conforme a corrente neoschumpeteriana, o objetivo central de uma política industrial deve ser construir ou garantir a competitividade, mas em termos sistêmicos. Para isso, deve-se combinar políticas de cunho horizontal com mecanismos seletivos de política, estimulando os empresários a buscarem o aprimoramento ou métodos de produção que se mostrem mais eficientes no longo prazo. (NASSIF, 2003, p. 14).

O sentido e racionalidade dessas intervenções devem ser considerados nos casos concretos, e aqui se revela a importância que a teoria evolucionária dá à análise política e à 
pesquisa empírica. Em sua obra Nelson e Winter dedicam uma extensa parte a este tópico. Consoante esses autores, o papel da análise é aumentar a compreensão do problema. Não se tem a pretensão de encontrar um "ótimo", conforme a modelagem neoclássica. O objetivo tático é identificar os próximos movimentos razoáveis no jogo do desenvolvimento da política. Para fazer essa avaliação, é preciso ter uma boa compreensão estratégica sobre o jogo em questão, e é precisamente nesse ponto que a análise política ganha relevância. (NELSON E WINTER, 2005, p. 542).

Apesar de variadas e identificadas concretamente, as intervenções governamentais na teoria neoschumpeteriana concentram-se usualmente em três grandes áreas: estímulo empresarial e coordenação de investimentos (redução de incertezas através da elaboração e negociação de estratégias de investimentos); gerenciamento da "destruição criadora" (amenizar os problemas decorrentes das mudanças estruturais); e a construção de aparatos institucionais (desenvolvimento de um marco regulatório e de políticas de desenvolvimento adequadas que cumpram com as duas outras tarefas). (BURLAMAQUI, 2000, p. 45).

Vale fazer uma breve menção sobre políticas de pesquisa e desenvolvimento, por estarem intimamente relacionadas com o tema deste estudo, e também por se tratar de um tema central na teoria evolucionária. Nelson e Winter dedicam especial atenção a estas políticas, por considerarem a atividade de pesquisa incerta, com dificuldade de classificação. Os autores tentam analisar qual seria o melhor regime para o tratamento desta atividade, descartando o controle governamental ou o monopólio, por centralizarem os esforços e não permitirem uma carteira ampla de projetos competindo entre si e diversificando as possibilidades de sucesso. Também rejeitam o cenário de mercado de concorrência perfeita e ausência de investimentos públicos, pela ausência de empresas com escala suficiente para projetos mais arriscados e ambiciosos. Assim, uma alternativa seria uma política pública de associação ou coordenação entre setor público e privado, a ser montada com base em uma análise empírica que pudesse detalhar e superar dificuldades nesse processo, como a rivalidade entre empresas que impediria o favorecimento de apenas algumas delas. (NELSON E WINTER, 2005, pp. 546-560). 
1.5 Principais pontos da análise teórica; importância da abordagem evolucionária para a pesquisa

Ao longo deste capítulo, tentei descrever como a teoria econômica, desde o princípio, procurou formular hipóteses para explicar a relação entre Estado e economia, utilizando diferentes métodos de análise e partindo de concepções teóricas distintas. A idéia de política industrial seguiu a reboque deste debate. Especialmente a partir da segunda metade do século passado, as experiências de industrialização japonesa e dos países do leste asiático fizeram com que economistas tentassem compreender como e em que circunstâncias a atuação estatal poderia colaborar (ou em sentido contrário prejudicar) o desenvolvimento industrial de determinado país ou região. A noção e conceito com que cada autor tratou o tema variaram, dependendo da importância que concedia às medidas amplas e não focadas (políticas horizontais), ou apenas às políticas objetivando determinado setor econômico (políticas verticais ou seletivas).

Há, como tentei demonstrar, um profícuo e extenso debate sobre esses temas, que abordam desde questões conceituais e meramente descritivas até o aspecto prescritivo, referente a recomendações e preceitos de como devem agir os governos para o melhor resultado ou desenvolvimento de suas economias. As posições defendidas podem ser consideradas conflitantes, embora, conforme Stiglitz, tenha recentemente havido uma superação das posições mais extremadas (que propunham o completo afastamento estatal, e, do outro lado, a tomada e substituição dos mecanismos de mercado). No dizer do autor:

\footnotetext{
"ironicamente, quase nenhuma das nações industrializadas bem-sucedidas seguiu qualquer das estratégias extremas. Elas são economias mistas nas quais o governo desempenha um papel importante. A questão apropriada a ser perguntada não é se o governo deve ter um papel, mas qual é esse papel e como ele pode ser desempenhado mais efetivamente". (STIGLITZ, 1996, p. 155, tradução nossa). ${ }^{22}$
}

Retomo minha afirmação inicial de que não foi meu objetivo neste capítulo tomar partido ou tentar demonstrar qual das teorias abordadas seria mais consistente ou adequada para explicar o Estado no desenvolvimento capitalista contemporâneo. Neste sentido, não cabe nesta conclusão o teste de alguma hipótese de trabalho ou afirmação de algum

\footnotetext{
22 "ironically, almost none of the successful industrial countries followed either of these extreme strategies. They are mixed economies in which government plays an important role. The appropriate question to be asked is not whether government should play a role, but what role and how can it be performed most effectively". (STIGLITZ, 1996, p. 155).
} 
resultado. $\mathrm{Na}$ verdade, cada uma das abordagens delineadas apresenta suas vantagens e virtudes explicativas, e podem ser utilizadas consoante se queira destacar ou menosprezar determinado aspecto ou questão. Sob esta perspectiva, para a análise de um problema empírico ou prático suas contribuições poderiam ser vistas como complementares, ao invés de contraditórias.

$\mathrm{O}$ arcabouço neoclássico poderá ser utilizado para explicar falhas e ineficiências geradas pela política de informática, em especial no período da década de oitenta, em que o protecionismo e restrição comercial foram largamente utilizados. A teoria do bem-estar neoclássica ressalta as vantagens e benefícios de uma economia de mercado, e sua potencialidade em gerar resultados positivos. O comércio internacional é encarado como essencialmente benéfico, e qualquer restrição ou distorção dos preços relativos tenderia a diminuir, ao invés de aumentar, o bem-estar da população.

A literatura de falhas de governo, embora tenha um aspecto prescritivo que pode ser considerado extremado, possui grande valia ao delinear um panorama teórico, que ajuda a esclarecer disputas e problemas internos do governo na formulação e implementação de políticas públicas. A oposição de parlamentares e burocratas adeptos da Zona Franca de Manaus - ZFM à Lei de Informática e o contingenciamento de verbas do Fundo Nacional de Desenvolvimento Científico e Tecnológico - FNDCT, temas que serão abordados nos próximos capítulos, podem ser considerados reflexos desses problemas, e melhor compreendidos sob a perspectiva desta literatura.

Já a abordagem evolucionária permite uma nova perspectiva sob o processo da competição, dando importância à inovação tecnológica e destacando que a eficiência e competitividade empresarial devem ser pensadas como um processo dinâmico, onde o aprendizado e as regras de decisão têm grande importância em determinar as próximas etapas do jogo da concorrência. A visão neoschumpeteriana abre uma janela sob a qual pode ser revista a relação entre Estado e economia. O Estado aqui tem um papel de grande relevância a ser exercido, no gerenciamento da "destruição criadora" e no estímulo e desenvolvimento de setores que, embora tecnologicamente promissores, não se desenvolviveriam sem sua intervenção. 
O cerne e intenção desta revisão de literatura foi definir os principais marcos teóricos com os quais sigo realizando o estudo empírico dos próximos capítulos. Os argumentos e temas levantados serão posteriormente retomados, em uma tentativa de identificar como os momentos e questões da política de informática brasileira podem dialogar com essas teorias, e em que medida elas explicam razoavelmente o desenvolvimento da indústria brasileira de computadores e equipamentos eletrônicos nas décadas de noventa e seguinte. A racionalidade pretendida pelo legislador ou pelo policymaker nacional, os problemas enfrentados e resultados atingidos e frustrados poderão ser melhor compreendidos à luz desta revisão da literatura.

Há, entretanto, um outro objetivo, ainda que indireto, a ser aqui destacado. Trata-se de identificar como o pesquisador da área do direito pode se aproveitar do debate exposto, sendo fortemente beneficiado por esta tentativa de construção interdisciplinar. Ainda que haja alguma dificuldade devido ao rigor metodológico da ciência econômica e ao amplo recurso a explicações matemáticas, busquei, ao resgatar alguns dos principais argumentos deste debate de forma sintética, demonstrar que são inteligíveis e em grande medida relacionados com temas do interesse do pesquisador e profissional do direito. Não são temas usualmente tratados ou utilizados nos discursos jurídicos, mas nem por isso devem ser desprezados, tendo grande relevância e potencial de contribuição, em especial considerando o tema das políticas públicas.

E com relação a este tópico vale a pena romper com a imparcialidade que vim adotando até aqui. Ainda que não se possa dizer que se trata de uma abordagem mais correta, a teoria neoschumpeteriana parece mais permeável e disposta a considerar os resultados de uma análise jurídica das políticas públicas.

Esclareço a afirmação acima: na perspectiva neoclássica, o papel das instituições parece limitado a pouco mais do que estabelecer as regras do jogo, não havendo um envolvimento maior ou uma relação positiva a ser construída de forma a favorecer o desenvolvimento do mercado. A condenação quase irrestrita da intervenção estatal na economia parece deixar pouco espaço para uma análise (especialmente a jurídica) que tente compreender ou explicar os componentes positivos ou negativos de um determinado marco regulatório ou arcabouço institucional de política pública. Mesmo sob a abordagem neoutilitarista, as falhas e defeitos advindos das políticas públicas derivam em sua maior parte 
da aplicação da racionalidade e das limitações dos agentes privados a funcionários públicos e burocratas. A motivação e incentivos que norteiam a conduta desses agentes são, nesse sentido, entendidas como abstratas e independentes do contexto concreto. Por esse motivo, a análise concreta de um determinado conjunto normativo, seja analisando seus princípios e regras positivadas, seja tentando compreender sua evolução e problemas enfrentados, parecem ter pouco a contribuir dentro desse marco teórico.

Já nos termos propostos pela escola evolucionária, as leis, políticas e organizações públicas são uma parte importante do ambiente que molda as atividades do setor privado. Neste sentido, a regulação e atuação estatal podem não só determinar limites, como também alterar as rotinas e racionalidades de decisão das empresas, influenciando assim nos rumos e buscas a serem realizadas posteriormente. São importantes, portanto, não apenas leis e regulamentos que estabeleçam direitos de propriedade e normas de funcionamento do mercado, mas também os sistemas educacionais e leis de fomento, que podem alterar o fluxo de pessoal treinado e as estratégias de pesquisa e desenvolvimento das empresas.

Assim como os demais elementos que compõem o cenário econômico-institucional no qual atuam as firmas, também as políticas públicas são consideradas a partir de um processo evolucionário, ao invés de uma paisagem estática. Esta evolução contínua é determinada por diversos fatores, incluindo aspectos econômicos e tecnológicos, mas também agregando considerações valorativas e culturais. Conforme Nelson e Winter,

\footnotetext{
"as políticas públicas evoluem em parte como respostas às mudanças nas demandas e nas oportunidades percebidas, mudanças que podem resultar da evolução de tecnologias privadas e das estruturas de mercado, ou de outras alterações identificáveis nas condições objetivas. As políticas públicas podem refletir não as mudanças nas condições objetivas, mas as alterações de valores, ou de compreensão". (NELSON E WINTER, 2005, p. 526).
}

Neste contexto, a forma como se deu a trajetória de uma política pública tem extrema relevância para a compreensão de seu momento atual, assim como para o exercício de fixar possibilidades e caminhos para os momentos subseqüentes. A base política e institucional atual decorreu da evolução e das escolhas feitas nos estágios anteriores, e parece também exercer uma influência relevante no evolver das etapas 
seguintes. A seguinte passagem de Nelson e Winter é especialmente útil para destacar este ponto:

\begin{abstract}
"A mudança ao longo do tempo no poder relativo de diferentes interesses e grupos dentro da sociedade provavelmente traz mudanças na política em seu contexto. As instituições e os procedimentos particulares para fazer, e para modificar, as políticas determinam a maneira pela qual as várias forças antes mencionadas são traduzidas em novas idéias políticas. Algumas vezes, o instrumental institucional para fazer política parece ter uma vida própria." (NELSON E WINTER, 2005, p. 527, grifos nossos).
\end{abstract}

Essa perspectiva da evolução de políticas públicas e de seu arcabouço institucional é complementada pela importante função dada pelos neoschumpeterianos à análise política. Conforme acima revisto, a análise e pesquisa empírica têm como objetivo aumentar a compreensão dos problemas, permitindo identificar as rotas de solução plausíveis e os prováveis comportamentos dos atores nos diferentes cenários. Através desses dois elementos abre-se espaço para estudos de casos que tentem relatar como, através do tempo, foi engendrada uma determinada opção política. Esta opção encontra suas explicações e pressupostos primordialmente no contexto de sua própria evolução, e isto somente é percebido através de estudos empíricos que tentem analisar esse processo com maior profundidade.

É neste contexto, portanto, que identifico haver uma maior oportunidade de diálogo da pesquisa jurídica (empírica, nos termos aqui propostos) com a abordagem neoschumpeteriana, justificando a afirmação acima. $\mathrm{O}$ alto valor contributivo reconhecido pela visão evolucionária às políticas públicas e ao Estado, como promotor do desenvolvimento, a importância da dinâmica evolutiva e dos fatores institucionais e políticos que influenciam esses programas de ação estatal e o papel da pesquisa e análise em apontar os caminhos possíveis a partir do exame das opções passadas, são elementos que aproximam essa abordagem do pesquisador em direito, na medida em que este se encontra em uma posição privilegiada para fazer uma análise aprofundada do quadro normativo que delineia e estabelece os limites de atuação de uma política pública. Apenas a título exemplificativo, o pesquisador em direito pode identificar como diferentes atores institucionais relevantes (tribunais de contas, ministério público, poder judiciário) se posicionam e modificam o conteúdo de uma dada política, além de traçar os caminhos através dos quais agentes interessados podem se mobilizar para atacá-la ou defendê-la (ação judicial, pedido de liminar, ação popular, ação direta de inconstitucionalidade, 
representação ou pedido de investigação às autoridades competentes), ponderando sobre suas chances de sucesso. E, a partir das descrições de Nelson e Winter, todos esses fatores podem ser plenamente considerados, e seriam uma contribuição relevante para uma análise evolucionária.

E é baseado nessa constatação que considero justificável, em termos teóricos, o exercício de reconstrução do processo de formulação e implementação da política brasileira de informática, a partir de uma perspectiva jurídica. Ainda que não adote as idéias evolucionárias em seu aspecto prescritivo (suas recomendações e proposições para formulação de políticas industriais), tomo esta abordagem como argumento que justifica a importância deste estudo, bem como os elementos e aspectos que pretendo priorizar. Destaco (como já mencionado anteriormente) que não se trata da elaboração ou aplicação de um modelo. Mas, propondo a reconstrução da política de informática desde o que entendo ser os seus primórdios até o momento e os debates atuais, sigo em alguma medida uma linha evolucionária de análise (embora esta afirmação deva ser compreendida de forma flexível e sem um apego rígido). E entendo que isto também possa representar uma pista ou princípio de tentativa de resposta de como o direito (e o estudo do direito) pode se relacionar com o tema do desenvolvimento da formulação de estratégias políticoinstitucionais neste sentido. 


\section{CAPÍTULO 2. ENTRE MILITARES E GUERRILHEIROS: a antiga Política Nacional de Informática}

A antiga política nacional de informática, que vigorou no país desde 1977, com a licitação dos minicomputadores ${ }^{1}$, até o início dos anos noventa, é um dos momentos mais interessantes para o estudioso de políticas públicas envolvendo setores econômicos, particularmente sob a perspectiva jurídica. É uma história que desafia alguns censos comuns, por revelar como se deu a construção deliberada de uma indústria local em um setor de alta tecnologia, partindo-se de uma base muito pequena ou mesmo inexistente.

A forma como se deram as decisões governamentais e como se alinharam os grupos de interesse dispostos a fomentar a pesquisa e a recém-nascida indústria também revelam a peculiaridade dessa política. Elementos e atos normativos de forte caráter ideológico e com objetivos expressos misturam-se com outros absolutamente casuais e decorrentes de fatores dos mais diversos, como a crise internacional do final da década de setenta e a redemocratização brasileira nos anos oitenta. Todos esses fatos revelam a complexidade de implementação de uma política pública, e como fatores exógenos podem alterar, para melhor ou pior, o programa inicial (se existente) pensado por seus formuladores.

É interessante notar o papel desempenhado pelo direito nesse período. Se por um lado foi fundamental, até mesmo porque os atos políticos se expressaram e emanaram sob a forma de atos normativos, por outro, foi também a ausência de regras rígidas e a presença de determinadas lacunas no corpo do ordenamento que deram aos burocratas governamentais a flexibilidade de moldar as instituições conforme seu viés ideológico, direcionando os órgãos e a administração para a instalação de uma política que favorecesse uma indústria local de informática.

Para fins dessa dissertação, a antiga política de informática interessa mais sob uma perspectiva histórica. Minha idéia com esse capítulo é compreender como o país chegou ao momento seguinte, ou seja, quais os elementos históricos e institucionais que levaram à construção de um determinado arcabouço na década de noventa.

\footnotetext{
${ }^{1}$ Ver seção 2.5 abaixo.
} 
Um segundo objetivo será utilizar essa política como contraponto ao que se seguiu na década seguinte. Para tanto, será também necessária a análise dos resultados econômicos e institucionais dessa política, e um estudo à luz do referencial teórico proposto no primeiro capítulo. A hipótese com a qual trabalho neste capítulo é a de reconhecer o êxito da antiga política em estabelecer no país uma capacitação no setor de informática e em criar um quadro institucional no qual empresas de capital local puderam surgir e competir no mercado interno, ainda que se deva admitir a ocorrência de falhas no fomento à competitividade, concentração empresarial e falta de inovação tecnológica de maior relevância.

O plano de trabalho do capítulo tem a ordem que se segue. Nas nove primeiras partes, realizo a reconstrução histórica da política. Como a minha idéia é privilegiar a perspectiva jurídica, optei por tomar objeto principal de estudo (e, consequentemente, como elemento divisório das seções) os marcos institucionais ou momentos de discussão política de grande relevância, tentando entender os fatores que marcaram esses períodos, e os resultados e problemas advindos dessas escolhas. Os atos normativos são, portanto, claramente meus principais objetos de análise, em detrimento de outras iniciativas e fatos, seja no âmbito governamental ou não ${ }^{2}$. Na décima parte, analisarei os resultados da política, procurando identificar onde foi bem sucedida e onde fracassou em seus objetivos. Por fim, na última parte, realizo o diálogo com os elementos teóricos e tento trazer conclusões, tendo em vista o objetivo deste capítulo.

\subsection{Cenário da indústria de informática no plano externo}

Costuma-se determinar como o início da informática o lançamento do ENIAC, em 1946, por dois pesquisadores da Universidade da Pensylvania. Nesse período, as pesquisas voltadas à informática estavam diretamente relacionadas aos esforços militares das nações, em especial durante a segunda grande guerra. Os países pretendiam desenvolver equipamentos mais sofisticados para seus projetos de aeronaves, mísseis e outras armas. Daí até a venda do primeiro computador comercial (ainda movido a válvula) foram mais 7

\footnotetext{
${ }^{2}$ A história da estatal COBRA é um claro recorte que procurei estabelecer. Enquanto a criação da empresa me pareceu um importante passo político para o estabelecimento de uma indústria local, os desenvolvimentos posteriores da empresa me parecem ter seguido mais uma lógica empresarial relativamente descolada dos andamentos da política. Por esse motivo, considerei apropriado tratar do início da empresa nas primeiras partes, mas não continuar a fundo nessa investigação no que se refere aos anos que se seguem.
} 
anos, quando a Sperry lançou seu primeiro modelo. Em 1958, a mesma empresa vendia o primeiro computador completamente transistorizado, o que representava uma evolução substancial com relação ao modelo anterior. (DANTAS, 1989, p. 8).

Conforme afirmado por Evans, a indústria de TI nos anos sessenta era constituída basicamente pela IBM e o que ela havia desenvolvido. (EVANS, 2004, p. 144). A indústria ainda não tinha sofrido a fragmentação em diversos segmentos de equipamentos, e seu único produto relevante para o mercado eram os mainframes. Esses computadores de grande porte eram soluções completas e fechadas, o que significa que adquirir o produto de uma empresa implicava a aquisição de seu hardware, software e periféricos da mesma. A IBM controlava cerca de $60 \%$ a $70 \%$ do mercado global, estando o restante nas mãos de seus poucos concorrentes (caricaturalmente conhecidos como os "sete anões"). (TIGRE, 1987, p. 14).

A situação começou a se alterar em meados da década de sessenta, quando os transistores foram integrados em uma pequena peça denominada chip. Isso permitiu o surgimento dos minicomputadores, máquinas de tamanho e preço muito inferiores aos mainframes. Os minicomputadores foram uma evolução tecnológica significativa, sendo a principal empresa do ramo a Digital Equipment Corporation - DEC, com seu DEC VAX. Entretanto, tais máquinas acabaram por se tornar obsoletas com a introdução dos microcomputadores, equipamentos derivados de uma das maiores revoluções da informática, que foi a introdução dos microprocessadores (pela Intel). Essas novas máquinas proporcionaram não apenas uma novidade tecnológica como também uma nova organização industrial. Como os fabricantes dos chips não produziam microcomputadores, estavam dispostos a vender seus produtos para qualquer empresa que quisesse entrar no mercado. Isso representou uma magnífica redução de barreiras à entrada de novas empresas no ramo, e o surgimento de diversos novos concorrentes (Tigre fala em torno de 150 - TIGRE, 1987, p. 14). Esses desenvolvimentos, entretanto, não devem ser exagerados, pelo menos para o período que vai até meados da década de setenta. Até esse momento, apesar de promissor, o mercado dos minis não passava de uma porcentagem do grande negócio, que ainda eram os mainframes da IBM.

Até essa época os governos de diferentes países apenas começavam a olhar com maior atenção para esse setor. A informática sempre esteve muito ligada à iniciativa 
governamental, em especial na área militar. Os principais exemplos de políticas públicas (coordenadas ou não) voltadas à computação nesse período encontravam-se nos países desenvolvidos. Os Estados Unidos foram o berço da indústria de informática, e suas empresas logo dominaram grande parte do mercado global. Contaram, para tanto, com forte apoio governamental, ainda que do tipo "indireto", conforme Tigre (1987, p. 39). Parte desses incentivos estava ligada a programas de defesa do governo, como o programa aeroespacial, que contribuiu para o desenvolvimento da indústria de semicondutores. Esses projetos exigiam um grande volume de pesquisa e desenvolvimento, além de criarem uma demanda que permitiu o crescimento das empresas e o conseqüente aproveitamento de economias de escala. $\mathrm{O}$ apoio indireto incluiu também incentivos fiscais, inclusive para produção externa (deixando que as empresas contratassem a fabricação em escala global).

$\mathrm{Na}$ Inglaterra a indústria de informática tinha um cenário especialmente favorável para o florescimento, e na década de sessenta o país dominava a tecnologia no setor. Sua política também esteve voltada para a defesa militar, fracassando, entretanto, por não possuir recursos da magnitude dos Estados Unidos, e por restringir os benefícios a empresas voltadas a equipamentos militares sem qualquer ambição no mercado comercial. Em um segundo momento, o governo inglês tentou adotar uma nova estratégia para promover a competitividade da indústria, ao promover uma "campeã nacional" - a ICL. (EVANS, 2004, p. 140).

As políticas dos países europeus eram razoavelmente similares, apesar de se distinguirem por algumas peculiaridades. Na Alemanha Ocidental, o Ministério da Pesquisa e Tecnologia Eletrônica financiava projetos que abrangiam treinamento, aplicações e atividades de pesquisa, objetivando a autonomia tecnológica e competitividade internacional em determinados nichos do mercado. Já a França lançou em 1966 o seu "Plano Cálculo", que dava suporte e estrutura administrativa às empresas locais, e coordenava as ações de governo-universidade-indústria (TIGRE, 1987, p. 39), além do famoso relatório "Nora-Minc", que estabeleceu as bases de discussão de uma estratégia de desenvolvimento da informática no país. (MARQUES, 2000, p. 95).

Fora do eixo Estados Unidos - Europa pouquíssimos países atentavam para a importância da indústria da informática. Um dos casos mais bem sucedidos e sempre muito citado é o Japão. Na década de 50 esse país não tinha qualquer vantagem comparativa 
aparente para uma indústria de informática. Entretanto, através de uma política agressiva e abrangente, que envolveu proteção alfandegária, restrições às importações, e uma atuação forte e ampla do MITI, o Japão tornou-se um dos grandes líderes no setor décadas mais tarde, sendo suas companhias competitivas internacionalmente e inclusive incorporando diversas empresas estrangeiras. (EVANS, 2004, pp. 139-140).

Poucos países em desenvolvimento atentaram ou tinham capacidade para elaborar uma estratégia de desenvolvimento para a indústria de informática. Concomitantemente ao Brasil, duas nações que também realizaram esforços nesse sentido foram Coréia do Sul e Índia, embora tenham seguido estratégias distintas, apresentando resultados também diversos.

Na América Latina, à parte do Brasil, praticamente não houve grandes esforços por parte do poder público para desenvolvimento de tecnologia e capital local no setor. Em estudo realizado no final da década de 1980, Correa cita que Argentina, Cuba e México chegaram a elaborar políticas nesse sentido, sendo, entretanto, o caso brasileiro o único no qual foi expedida uma lei especial aplicável à produção, comercialização e pesquisa e desenvolvimento ligados à informática ${ }^{3}$. (CORREA, 1996, pp. 5-30).

Esta foi uma breve menção às políticas para o setor de informática que estavam sendo desenvolvidas por diferentes países durante os anos sessenta e setenta. O que importa aqui não são as peculiaridades ou detalhes de cada política, mas apenas constatar que, ao iniciar uma política de informática que iria se aprofundar ao longo das décadas seguintes, o Brasil não estava seguindo um caminho isolado, ou sendo pioneiro nessa empreitada. Os burocratas e técnicos brasileiros estavam cientes do desenvolvimento do setor no exterior, e como os países desenvolvidos estavam lidando com isso, e muitos de seus passos, especialmente no início, foram baseados nessas observações. Ao mencionar o início dos trabalhos da CAPRE, Dantas afirma que este órgão seguiu as pegadas de políticas executadas em países mais desenvolvidos como a França, a Alemanha, a Inglaterra, o Japão e os Estados Unidos. (DANTAS, 1988, p. 46).

\footnotetext{
${ }^{3} \mathrm{O}$ autor chega a descrever a política argentina, informando que lá não se chegou a recorrer à reserva de mercado, permanecendo as medidas principalmente no campo dos incentivos tarifários.
} 
Assim, a política de informática brasileira pode ser inserida no contexto global da indústria do período. E, dentre outras características, esse contexto tinha por pontos básicos: a corrida em termos eminentemente nacionalistas desenvolvidas por países em sua maioria desenvolvidos por um setor de informática forte e competitivo; e a estreita aliança entre as empresas de informática e as estratégias militares de defesa das nações. Esses fatores se repetiram e tiveram repercussões determinantes no caso brasileiro.

\subsection{Os primórdios da política brasileira}

Estabelecer um ponto histórico inicial para uma pesquisa possui um elemento arbitrário ou de discricionariedade. Diversos poderiam ser considerados como o primeiro fato relevante da narrativa. Uma vez que pretendo discutir mais as características das políticas públicas desenvolvidas, darei preferência a esses fatores sobre assuntos e fatos majoritariamente técnicos. Por esse motivo, tomo como início os fatos e causas que deram origem ao que entendo ser um ponto institucional que, se não for o primeiro, certamente é um divisor de águas na história da política informática brasileira: a criação da CAPRE, órgão que, conforme será visto nos itens 2.3 e 2.4 abaixo, foi pioneiro na promoção ao setor de informática e teve uma grande relevância na instituição da proteção à indústria nesta primeira fase.

O país marca sua entrada na era da informática em 1957, quando o governo do estado de São Paulo adquire um Sperry-Univac-120, ainda da geração dos computadores a válvula, com o propósito de calcular a vazão do consumo de água na capital. Um ano depois, a Pontífice Universidade Católica do Rio de Janeiro - PUC-RJ torna-se a primeira instituição de ensino brasileira a ter um computador, ao adquirir um B-205 da Burroughs. Já no ramo privado o primeiro equipamento desse tipo foi um Ramac 305 da IBM, comprado em 1959 pela Anderson Clayton4. (DANTAS, 1988, p. 19).

Em 1970 o Brasil era um típico mercado de informática de um país em desenvolvimento, dominado por empresas estrangeiras e com tecnologia vinda de fora ${ }^{5}$. Já era entretanto um grande mercado em potencial (o $12^{\circ}$ maior do mundo à época), apresentando taxas de crescimento bem superiores à média dos mercados mundiais.

\footnotetext{
${ }^{4}$ Apenas a título de curiosidade, a máquina possuía dois metros de largura, um metro e oitenta de altura, com mil válvulas em cada porta de entrada e saída da informação e ocupava um andar inteiro da empresa.

${ }^{5}$ Conforme Evans (1986), que cita como principais fornecedores a IBM e a Burroughs, ambas presentes no país desde 1924.
} 
(ADLER, 1986, p. 678). Esse crescimento e dimensão certamente não escaparam aos militares e ideólogos nacionalistas, certos de que isso seria uma vantagem a ser explorada para a implantação de uma indústria de informática local.

O primeiro esforço interno de pesquisa na área da informática data de 1961, quando alunos do ITA construíram um computador completamente transistorizado, utilizando apenas transistores nacionais. O ITA foi a primeira escola de engenharia eletrônica do país, criada no final dos anos quarenta, no afã desenvolvimentista que se vivia então. Seu propósito era permitir o estabelecimento de uma indústria aeronáutica, o que iria requerer um centro de ensino e pesquisa à altura deste desafio. O ITA teria indiretamente um papel essencial na política de informática brasileira. Dos seus bancos saíram alunos que, frustrados com a ausência de um mercado para desenvolver suas aptidões na informática, estariam dispostos a defender e construir uma indústria nacional nesse setor.

No bojo da administração pública, o primeiro órgão a se preocupar com a questão da informática foi o GEACE, criado em 1959 para promover e coordenar a concessão de incentivos para a aquisição de equipamentos eletrônicos. Foi o GEACE que aprovou, por exemplo, a importação do computador pela PUC-RJ, assim como a primeira máquina adquirida pelo IBGE. (DANTAS, 1988, p. 19). O GEACE foi posteriormente extinto no governo Jânio Quadros, por considerar cumpridas as suas atribuições.

A partir desses episódios, pode-se constatar que a figura do Estado esteve presente desde os primeiros passos da informática no Brasil. Seja como consumidor-usuário ou centro de ensino e pesquisa, foi a decisão ou necessidade política que trouxe ao país esse avanço tecnológico, ainda incerto à época. Tais casos, entretanto, encontravam-se relativamente isolados, e não havia neles a pretensão de criação e fortalecimento de uma indústria de informática interna. Até mesmo pela completa ausência de empresas locais envolvidas nesse setor, o governo não planejava esforços mais expressivos nesse sentido. Foi apenas em meados dos anos sessenta que se iniciou o processo que um técnico da FINEP vai posteriormente chamar de tomada de "consciência tecnológica", uma série de ações mais sistemáticas voltadas à criação de um corpo técnico local. (FRANKEN, 1976, pp. 3-9). 
Esse processo começa timidamente, através de apoio financeiro concedido por órgãos públicos como o BNDE, o CNPq e a CAPES para atividades de pesquisa e desenvolvimento na área. Nesse momento embrionário, o esforço de pesquisa na área não nasce em decorrência de uma demanda ou necessidade da indústria privada, nem tem qualquer relacionamento com interesses empresariais ou intuito lucrativo. Pelo contrário, foi uma demanda gerada pelo setor público.

Em 1963, por obra de José Pelúcio, um antigo funcionário ligado ao grupo misto BNDE-CEPAL, o BNDE abriu um fundo para financiamento de projetos nacionais. $\mathrm{O}$ FUNTEC tem especial relevância por ter viabilizado o projeto FUNTEC 111, que nasceu a partir de uma demanda da marinha brasileira, defendida por uma figura de grande relevância para a política de informática, o capitão José Luís dos Guaranys Rego.

A marinha tinha especial interesse no desenvolvimento de uma estrutura nacional que cuidasse do desenvolvimento e manutenção de equipamentos de informática. No final dos anos sessenta ela havia colocado em movimento seu 'Programa de Renovação dos Meios Flutuantes', incluindo a aquisição de seis fragatas de última tecnologia na época da Inglaterra. Como as embarcações eram sensivelmente dependentes do bom funcionamento dos equipamentos eletrônicos nelas contidos, a marinha, e em especial o capitão Guaranys, começou a se inquietar com a manutenção desses instrumentos, e com a falta de conhecimento local para essa tarefa, o que os deixava reféns da tecnologia e conhecimento de uma empresa de origem estrangeira. (EVANS, 1986, p. 193).

Este é um exemplo que explica em parte a demanda à época por pesquisas na área de informática criada pelo setor público. Se não havia interesses privados ou perspectiva de lucro para fomentar o desenvolvimento tecnológico, isto é, na ausência de mercado, havia uma séria preocupação militar e uma doutrina de "segurança nacional", que demandava criticamente o domínio dessa tecnologia. Essa ideologia é exponencialmente aumentada com o movimento político de 1964, que acentua as perspectivas militares e sua preocupação com dependência de tecnologia externa. Com base nessa doutrina, os militares à época desenvolveram um grupo respeitável de empresas fornecedoras de equipamentos de defesa, chegando inclusive a contribuir com as exportações do país. Passam, assim, a se identificar com a luta 'nacionalista' e a busca por 'autonomia 
tecnológica', o que veio favorecer os projetos e idéias para a geração de cérebros e empresas voltadas ao desenvolvimento da informática. (EVANS, 2004, pp. 148-149).

A preocupação com a segurança nacional e com o desenvolvimento tecnológico autônomo do país atinge seu auge no II PND, do governo Geisel. Este documento consubstanciou o projeto das elites militares de um 'Brasil Potência', cujo núcleo central estava integrado pelas metas de um novo padrão de industrialização e fortalecimento da empresa privada nacional. Esse 'novo nacionalismo' pretendia conciliar o projeto político de grande potência com uma sociedade industrial moderna e um grau maior de interdependência na economia mundial. Sua grande novidade seria o reconhecimento da importância do desenvolvimento científico e tecnológico: a autonomia e a soberania nacionais passam a depender da construção de uma capacitação interna. Essas concepções e idéias permitiram o surgimento e ampliação de espaço de ação política dos defensores de uma política de informática. (TAPIA, 1995, pp. 23-24).

Se Guaranys e os militares representavam um dos pilares da pesquisa e do que posteriormente viria a ser a política de informática, um outro, certamente, deve ser creditado a Pelúcio e aos economistas do BNDE. Treinados e influenciados pelo pensamento da escola da CEPAL da época, esses economistas consideravam a dependência tecnológica fortemente entrelaçada com a dinâmica do subdesenvolvimento. Esse diagóstico vai defender que o desenvolvimento econômico não se exprime apenas através de altas taxas de crescimento, mas também na capacidade interna de compreensão e interação com as forças modernizadoras em vigor no mundo. Os adeptos dessa doutrina acreditavam que o Brasil atingiria a autonomia se tivesse a capacidade de tomar decisões tecnológicas, ainda que isso não significasse a rejeição completa de tecnologia estrangeira. (ADLER, 1986, p. 686).

A esses dois grupos vai ainda se juntar um terceiro, formado pelos ex-alunos do ITA e de outras escolas de engenharia eletrônica, como a Politécnica da USP e a PUC-RJ. O crescimento econômico acelerado, o surto industrializante e disseminação da informática nesse período geraram uma grande demanda por engenheiros, e essas escolas estavam se modernizando e formando alunos para trabalhar na área. No entanto, a indústria brasileira de computadores não possuía espaço para que esses profissionais, alguns inclusive com pós-graduação em centros de excelência no exterior, realizassem uma atividade técnica 
compatível com a complexidade de sua formação. Em sua maioria, esses técnicos tornavam-se vendedores de equipamentos IBM e outros, ou se engajavam no processamento de dados para o governo federal. (EVANS, 1986, p. 792). Para eles, a construção de uma indústria brasileira de informática era não apenas um objetivo abstrato ou ideológico, mas uma necessidade para concretização de suas ambições profissionais e científicas, e nesse sentido passaram a ver com bons olhos as idéias nacionalistas que pregavam autonomia tecnológica.

Militares preocupados com a segurança nacional, economistas de formação cepalina e técnicos nacionalistas frustrados: esta era a base que daria sustentação e fomentaria a pesquisa de informática no Brasil, e que formaria os alicerces da política protecionista por vir. Conforme Tapia:

\footnotetext{
“o importante a sublinhar é a convergência entre o nacionalismo militar enraizado na Doutrina da Segurança Nacional e aqueles das elites civis burocráticas e científicas - ligado à idéia do desenvolvimento científico e tecnológico como fator de soberania para a autonomia". (TAPIA, 1995, p. 25).
}

Um grupo bastante heterogêneo comungando este objetivo, não sem contradições, desconfianças e desavenças. Embora apoiasse o nacionalismo ideológico dos outros dois grupos, os militares receavam de intelectuais como potenciais núcleos de subversão. Atritos e contradições foram freqüentes e determinaram parte dos rumos da política de informática.

Um último fator a ser mencionado como gerador de demanda de pesquisa de informática no país, este sim um ponto de necessidade prática, foi o crescimento e modernização da burocracia federal, que se viu cada vez mais diante de desafios que apenas poderiam ser superados com o auxílio de novas tecnologias. Entretanto, tratando-se de problemas específicos do governo brasileiro, as multinacionais tinham pouco interesse em investir para solução desses problemas, cabendo a técnicos e pesquisadores nacionais tomar para si a tarefa. Os principais exemplos dessas pesquisas voltadas a resolver problemas do governo são: o trabalho do SERPRO, criado em 1964, para organizar e agilizar a crescente complexidade e volume do sistema tributário, em especial do imposto sobre a renda, o que deu origem ao 'concentrador de teclados'; e o processamento dos dados do censo de 1970, que, graças ao esforço contíguo do IBGE e da PUC-RJ, foi 
realizado no tempo recorde de seis meses, levando à criação do IBI, órgão ligado ao Ministério do Planejamento 6 .

Em seu tempo, o FUNTEC 111 de Pelúcio e Guaranys acabou ganhando grande importância, e em 1971 foi objeto do Decreto 68.267, que criou um Grupo de Trabalho Especial - GTE para sua coordenação. A administração do projeto deveria então contar com um representante de cada um dos principais órgãos envolvidos, a marinha e o BNDE. O GTE tornou-se um fórum de discussões e um ator institucional onde se debatiam os projetos de informática no país. O projeto de construção do primeiro computador nacional amadureceu, e o grupo decidiu as universidades responsáveis pelo protótipo: a Escola Politécnica de Engenharia da USP e seu LSD ficaram com o desenho do hardware ${ }^{7}$, e o software ficaria a cargo da PUC-RJ, em um projeto que, futuramente, viria a ter resultado como o G-10, primeiro computador integralmente criado no país ${ }^{8}$.

Por fim, o último fato relevante desse momento preliminar é a apresentação pelo homem que viria a ser diretor do IBI, Antônio César Olinto, de um relatório encomendado pelo IBGE sobre a situação da informática no Brasil. Entregue em dezembro de 1971, o Esboço de Plano Nacional para a Computação Eletrônica no Brasil trouxe pela primeira vez dados relevantes sobre a dimensão do mercado brasileiro, afirmando haver no país cerca de 600 máquinas, sendo $75 \%$ delas IBM, e estimando um crescimento anual de $30 \%$, enquanto o mercado mundial ia a apenas $20 \%$. O relatório propunha uma planificação que estabelecesse as diretrizes e metas para o setor no mercado nacional, visando, em especial, à auto-suficiência na fabricação de hardware, entendida como aquisição de know-how de fabricação. Também sugeria a criação de uma comissão que seria responsável pela elaboração de uma política nacional para o setor e por realizar recenseamentos de computadores em funcionamento no setor público. Esse relatório foi utilizado como base para que, no ano seguinte, fosse criada a CAPRE. (DANTAS, 1988, p. 40).

\subsection{A CAPRE e a criação da COBRA}

A CAPRE pode ser considerada o primeiro grande passo institucional do governo brasileiro rumo à política protecionista. Esse órgão do Ministério do Planejamento teria

\footnotetext{
${ }^{6}$ Sobre essa história ver DANTAS, 1988, pp. 35-39.

${ }^{7}$ O projeto recebeu o nome de "Patinho Feio", devido a uma disputa com a UNICAMP.

${ }^{8}$ Para uma análise mais aprofundada dessa história ver HELENA, 1984.
} 
papel decisivo na implantação da reserva de mercado, graças a uma ampliação de poderes recebida alguns anos após a sua criação, e às idéias de seus membros para o setor.

Quando de sua criação, entretanto, em abril de 1972, a CAPRE ainda não tinha a capacidade política para desempenhar essas funções. Algumas das sugestões propostas no documento apresentado ao IBGE não haviam sido acatadas. O decreto criador do órgão, 70.370/72, restringia suas atribuições, principalmente, ao setor público, dentro do qual a CAPRE teria poder para opinar sobre compras e locações de equipamentos (artigo $\left.2^{\circ}, b\right)$. Todavia, analisando a exposição de motivos deste decreto (Exposição $n^{0}$ 012-B, de autoria do então ministro do planejamento, João Paulo dos Reis Velloso), nota-se que já estavam na pauta algumas das principais preocupações que iriam nortear os trabalhos da CAPRE no futuro: a importância da informática e de sua utilização no gerenciamento de dados e informações em um ambiente de complexidade administrativa; uma preocupação com a racionalidade na utilização dos recursos, e com a 'ociosidade' dos equipamentos já instalados; e, em especial, uma atenção com os custos desses equipamentos e seu peso na balança comercial.

A CAPRE era composta por um conjunto de representantes de órgãos e entidades governamentais e administrativas, alguns dos quais já tinham demonstrado interesse profundo no setor de informática, como o Ministério do Planejamento, as Forças Armadas, o BNDE, o SERPRO e o IBI. Em seu início, sua atuação ainda era tímida, devido às limitações funcionais. O órgão, então, ocupou-se em estudar e levantar dados sobre o setor que pretendia fomentar, e a levantar capital político para sua empreitada. Em 1973 a CAPRE divulga um relatório dando dados específicos sobre o setor e a capacidade informática instalada no país. Os números apresentados mostram em si pouca relevância, mas as conclusões são importantes para compreender os rumos tomados pela CAPRE. Acusou-se um déficit de recursos humanos em informática (13,5\% de operadores, $22,6 \%$ de programadores e $10,9 \%$ de analistas), e a pouca experiência dos profissionais no mercado (média em cerca de três anos). (DANTAS, 1988, p. 45). Com base nessa e em outras conclusões, a CAPRE começa a elaborar os seus "planos diretores", voltados à racionalização do uso dos equipamentos na administração pública.

Outra atuação relevante da CAPRE nessa fase inicial ocorreu junto às universidades. Tentando cativá-las para seus objetivos e fornecer capacitação tecnológica, 
foram realizados o Plano Nacional de Centros de Computação e o Plano Nacional de Centros de Informática, que eram programas de remanejamento de equipamentos eletrônicos entre as instituições de ensino, a fim de viabilizar as demandas de cada uma por modernização. (DANTAS, 1988, p. 45). Além disso, as universidades foram trazidas para o debate da política nacional de informática através dos Seminários de Computação na Universidade - SECOMU, dentro dos quais a comunidade técnico-científica começou a se mobilizar para discutir qual a melhor estratégia para a indústria nacional.

À parte dessas tarefas, este momento inicial talvez seja melhor compreendido se encarado como uma preparação. A CAPRE estava organizando sua atuação, tentando obter informações e formulando um modelo de política, buscando e entrando em contato com órgãos e indivíduos que compartilhavam de suas visões, e preenchendo seus quadros. $\mathrm{O}$ órgão foi assim adquirindo força política e reconhecimento na esfera administrativa e na comunidade técnica e científica. Tornou-se, dessa forma, o "lar dos técnicos nacionalistas frustrados" (EVANS, 1986, p. 793) ou, nos termos de Adler, o "quartel-general dos guerrilheiros ideológicos" (ADLER, 1986, p. 691)9.

Enquanto a CAPRE passava por seu momento inicial se fortalecendo politicamente, o GTE tinha que tomar decisões críticas para o futuro do projeto. Além do computador desenvolvido internamente, a cargo da escola de engenharia da USP e da PUC-RJ, amadurecia a idéia de uma associação com o capital externo para a produção local de computadores. A associação deveria seguir o modelo dos "terços", já utilizado anteriormente na implantação de uma indústria petroquímica, com um terço do capital vindo do governo, um terço de uma empresa nacional e a última parte de uma empresa estrangeira, responsável ainda por trazer sua tecnologia para o grupo. (HELENA, 1984, pp. 12-13).

Surgiu aqui uma primeira divergência entre o nacionalismo da doutrina de segurança nacional e o dos técnicos e economistas. A Marinha havia escolhido, em 1971,

\footnotetext{
${ }^{9} \mathrm{O}$ surgimento e fortalecimento dessa "guerrilha ideológica" é central no argumento do autor, que tenta demonstrar a importância do fator cognitivo ou ideológico no desenvolvimento das instituições. Os guerrilheiros ideológicos são identificados como "a group of ideologically motivated actors who enjoyed the support of scientific and technological institutions and funds established in the late 1960s to develop Brazil's technological potential attempted to convince the elites otherwise. These actors included scientists, technologists, and technocrats, who, for the sake of their ideas and ideology, elected to act as political and ideological "guerrillas" within public institutions". (ADLER, 1986, p. 677).
} 
computadores FM 1600 da empresa inglesa Ferranti para suas embarcações. Para seus membros fazia todo sentido que a associação fosse feita com essa empresa inglesa, para garantir a absorção da tecnologia e fabricação local desses equipamentos. Entretanto, alguns membros do GTE, mais preocupados com a formação e crescimento de um grupo local, duvidavam seriamente da viabilidade comercial de uma empresa voltada exclusivamente a equipamentos militares.

Foi muito difícil encontrar uma empresa nacional que aceitasse a parceria. A área de informática era muito incipiente, e os riscos altos demais para que os grandes grupos empresariais concordassem em entrar no negócio. O tripé acabou sendo composto com a E.E. Equipamentos Eletrônicos, que já mantinha relações comerciais com as forças armadas e buscava consolidar esse relacionamento. (EVANS, 1986, p. 793). Quanto à empresa estrangeira, após uma longa pesquisa, o BNDE passou a defender a parceria com a Fujitsu japonesa, mais voltada à área de computadores comerciais e disposta a abrir sua tecnologia. Com essa associação seria possível entrar no mercado de minicomputadores e aplicações comerciais, o que daria maiores chances de viabilidade do empreendimento.

Sem qualquer possibilidade de consenso acerca de um nome, a saída foi aceitar as duas propostas. Seriam constituídas duas empresas sob uma mesma holding - a Digibrás, sendo uma destinada a equipamentos militares em associação com a Ferranti e a outra voltada a aplicações comerciais. A segunda empresa nunca saiu do papel, mas a primeira tornou-se uma das mais promissoras tentativas de criação de um 'campeão nacional' em informática brasileiro. A COBRA nasce em julho de 1974, com participação societária da Digibrás, da Ferranti e da E.E. Confirmada a posição defendida pelo BNDE de inviabilidade comercial do equipamento FM 1600, decide-se então pela fabricação local do Argus 700, vendido no país sob o nome Cobra 700, um controlador de processos industriais que havia sido lançado há pouco pela Ferranti. (HELENA, 1984, p. 15).

\subsection{Choque do petróleo e a restrição às importações}

Se já havia alguns órgãos e um núcleo de indivíduos que defendiam uma política de informática nacional (inclusive através de uma publicação local, a revista bimestral Dados \& Idéias), os instrumentos específicos e uma motivação econômica mais acentuada ainda não estavam definidos. Esse problema foi solucionado em 1975, por uma crise 
internacional com fortes repercussões econômicas em todo o mundo: os choques do petróleo.

A crise internacional trouxe à tona a fragilidade do modelo do "milagre econômico" implantado pelos militares, tornando insustentáveis os números da balança de pagamentos brasileira. O governo começou a tomar maior cuidado e atenção com os setores e empresas responsáveis pelo déficit comercial do país, e o setor de informática foi naturalmente apontado como um dos vilões. À época, foi detectado que de todo o mercado brasileiro de informática, 98,6\% era suprido por importações. As empresas estrangeiras foram apontadas como responsáveis por grande parte do problema. Em 1974, essas sociedades acumularam um déficit comercial de 619,3 milhões de dólares. Importaram 859,9 milhões de dólares e exportaram apenas 240,6 milhões. (DANTAS, 1988, p. 59).

Com o agravamento da crise, ao final de 1975 o governo começa a tomar medidas para controle das importações e gerenciamento do problema cambial. O Conselho de Desenvolvimento Econômico - CDE tomou duas medidas de caráter geral (ou seja, se aplicavam a todas as importações, independente do setor econômico envolvido) para barrar a entrada de bens estrangeiros no país. A primeira foi a instituição de um depósito prévio, no valor da mercadoria importada, a ser feito pelo importador, à disposição no Banco Central. Essa medida significava que o importador precisaria levantar recursos para realização do depósito, encarecendo a operação. A segunda medida, atingindo as compras de máquinas e equipamentos estrangeiros, exigia que esses bens fossem financiados (pelo fornecedor estrangeiro ou instituições estrangeiras) para pagamento mínimo em cinco anos, o que era uma forma de evitar o desembolso imediato de dólares pelo importador ${ }^{10}$. A importância de citar essas restrições de caráter geral às importações é demonstrar que a crise transcendia em muito o setor de informática. Os computadores com certeza agravavam esse quadro, mas nem de longe eram os únicos responsáveis.

O CDE estabeleceu ainda que alguns setores econômicos, considerados mais críticos ou com maior peso na balança de pagamentos, teriam um controle mais estrito de suas importações. Esses setores eram a aeronáutica, o de material ferroviário, e, por fim, a indústria de computadores. Ao se questionar quem deveria realizar esse controle na área da

\footnotetext{
${ }^{10}$ Conforme publicado em Dados \& Idéias, n. 4, fev. mar. 1976, p. 21.
} 
computação, a CAPRE acabou surgindo como a escolha óbvia. Assim, em 3 de dezembro de 1975 o CONCEX promulgou sua Resolução 104, segundo a qual a emissão de guias para importações de computadores eletrônicos e seus periféricos passou a depender de prévia anuência da CAPRE. Em princípio, nem os técnicos da CAPRE se deram conta daquilo que lhes proporcionava essa resolução. Mais preocupados com o volume de trabalho, eles não perceberam de imediato o grande potencial dessas medidas. Involuntariamente (ao menos aparentemente), a crise cambial e a Resolução do CONCEX deram à CAPRE um instrumento poderoso de política industrial. Agora eram eles quem definiam que equipamentos, partes e peças entravam no país, e quais não poderiam ser importados. Como nenhuma empresa era capaz de produzir computadores sem importar componentes, isso significava que a CAPRE, em última instância, tinha o poder de definir quais equipamentos seriam fabricados e por quem. (DANTAS, 1988, pp. 60-61).

Certamente essa delegação de poderes seria utilizada apenas para colaborar com a solução do problema da balança de pagamentos se tivesse sido concedida a um órgão ou grupo de burocratas indiferentes aos rumos do setor de computação. Não era esse o caso da CAPRE, que, com habilidade política para não contrariar frontalmente autoridades e interesses influentes, converteu essa função no grande instrumento da política de informática brasileira.

Percebendo a importância daquilo que poderiam realizar com suas novas atribuições, os técnicos da CAPRE trabalharam para viabilizar suas ambições. A primeira tarefa era alterar o funcionamento do órgão, dando-lhe maiores poderes e abrangência de atuação. Isso foi realizado através do Decreto 77.118/76, que aumentou as funções da CAPRE, e criou o Conselho Plenário, que teria, entre outras tarefas, a de "propor as diretrizes da Política Nacional de Informática e o Plano Integrado de Informática” (artigo

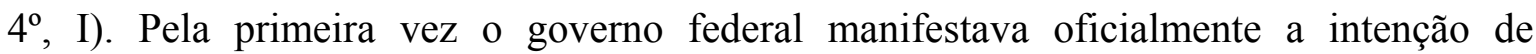
estabelecer uma política de informática, em termos evidentemente muito mais amplos que no passado.

A crise cambial ocasionada pelos choques do petróleo representou um fator determinante nesta fase embrionária da política de informática brasileira. Foi devido a ela que a CAPRE obteve o seu principal instrumento de atuação, fundamentando política e administrativamente a reserva de mercado para mini e micro computadores a ser 
implantada posteriormente, e que permaneceria durante o final da década de setenta e toda a década de oitenta. Entretanto, seria um erro creditar apenas a este elemento a viabilidade dessa política. Ao contrário, ela só foi possível devido a todo trabalho já realizado anteriormente. Em primeiro lugar, a CAPRE já havia diagnosticado a necessidade de racionalização e a "ociosidade" dos equipamentos em funcionamento, o que dava margem para uma restrição quantitativa de importações por um tempo limitado, sem prejuízo para a economia do país. Além disso, havia confiança de que o país já tinha passado por um primeiro amadurecimento no setor, fruto das pesquisas e trabalho do GTE e da recémnascida COBRA, de órgãos da administração pública como o SERPRO e o IBGE, assim como das universidades brasileiras, que com seus cursos de engenharia eletrônica estavam despejando no mercado mão-de-obra que poderia cuidar da produção ${ }^{11}$.

Por fim, havia um último fator a ser considerado. Por mais que tivesse se tornado a 'guardiã do portão' ${ }^{12}$ de entrada de equipamentos e componentes no país, não fazia sentido para a CAPRE restringir todo o mercado de computação às empresas nacionais. Não havia a menor capacidade de potenciais produtores locais suprirem sem importações a demanda de todos os segmentos, em especial os de máquinas de grande porte. Era preciso identificar e estabelecer um setor no qual a indústria brasileira pudesse se expandir e adquirir capacidade tecnológica mediante uma política protecionista. A resposta encontrada foi o mercado de mini e microcomputadores, o que levou a primeira grande batalha política da CAPRE.

\subsection{Reserva de mercado e a licitação dos minicomputadores}

Os anos de 1976 e 1977 foram decisivos para a política de informática. A CAPRE sabia que o mercado de mainframes e de máquinas de grande porte já estava consolidado no país e no mundo, e seria um disparate tentar proteger esse segmento e criar capacitação nacional para competir com a gigante mundial IBM. O mesmo não ocorria com o mercado de mini e microcomputadores, o chamado lower-end da computação, que ainda representava uma parcela pequena da informática e não tinha interessado aos grandes fabricantes. Para se ter uma idéia, em 1975 as vendas de minicomputadores representavam apenas $15 \%$ do mercado de mainframes no país. (EVANS, 1986, p. 793).

\footnotetext{
${ }^{11}$ Conforme sugerido em Dados \& Idéias, nov. 1980, p. 56.

${ }^{12}$ Expressão de ADLER, 1986, p. 692.
} 
Os rumos dessa história, no entanto, estavam mudando. Apesar de pequeno, o mercado de minicomputadores era o que mais crescia no mundo, em decorrência do uso generalizado a que se prestavam tais máquinas, inclusive por médias e pequenas empresas, e ao potencial representado por suas aplicações em sistemas administrativos em entrada de dados, em controle de processos, teleprocessamento ou como caixas registradoras eletrônicas. (CONCEIÇÃO, 1976, pp. 16-20). O grande fator determinante foi que as empresas pioneiras e que dominavam esse ramo eram razoavelmente recentes, e estavam mais preocupadas em ganhar espaço e suprir a demanda do mercado norte-americano. Por essa razão elas não tinham estabelecido redes internacionais e iniciado a fabricação de seus produtos em muitos países do mundo, como era o caso do Brasil.

Esta era a oportunidade que a CAPRE precisava. Um mercado em expansão, produto em fase de disseminação, tecnologia não especializada e organização industrial ainda não consolidada no país. Uma legítima “janela de oportunidade”, que os guerrilheiros ideológicos poderiam utilizar. Conforme Adler:

\begin{abstract}
"O momento não era irrelevante. $\mathrm{O}$ fato de que as multinacionais, em especial a IBM, não haviam começado a fabricar os mini e microcomputadores no Brasil quando os esforços nacionais foram inicialmente concebidos constituía uma oportunidade. Pois se essas empresas já tivessem estabelecido um nicho no Brasil com esses sistemas, o custo e dificuldade de empurrá-las para fora do mercado poderia ser grande demais.” (ADLER, 1986, p. 685, tradução nossa ${ }^{13}$ ).
\end{abstract}

A “janela", entretanto, não ficaria aberta por muito tempo, e os técnicos da CAPRE sabiam disso. Começavam a tomar forma e dar resultados as estratégias comerciais para minicomputadores das principais empresas como Burroughs, Olivetti, Digital, Data General e Hewlett-Packard. O ponto crítico desse processo ocorre em meados de 1976, quando a IBM, até então fora do mercado dos minis, anuncia sua entrada nesse segmento com seu 'sistema /32', acompanhado de uma campanha publicitária maciça.

\footnotetext{
13 “Timing was not irrelevant. That MNCs, in particular IBM, had not yet begun manufacturing mini and microcomputers in Brazil when the national endeavor was first considered constituted an opportunity. For had the MNCs already established a niche in Brazil with these systems, the cost and difficulty of pushing them out of the market might have proved too high." (ADLER, 1986, p. 685). No mesmo sentido Evans afirma "Had DEC been willing to start making the PDP-8 in Brazil in 1970, not an unreasonable proposition from DEC's point of view since it was already na "old" machine by this time, the Brazilian response would almost certainly have been highly positive. If IBM had been interested in initiating local production of a machine like the system 32, the same would almost certainly have been true. If either had happened, the possibility of the 1977 mini competition would have been pre-empted. Once TNCs had become involved in that segment of the market it would have been very difficult to dislodge them”. (EVANS, 1986, p. 797).
} 
Considerando a urgência, o Conselho Plenário da CAPRE aprova a Resolução $\mathrm{n}^{\circ} 1$, de 15 de julho de 1976, sob o título "Recomendações sobre a política nacional de informática". A Resolução 1 realiza um apanhado geral da situação da indústria de informática. Em suas premissas são mencionadas a importância estratégica do setor para a segurança nacional, a consolidação do mercado de máquinas de médio e grande portes, e a oportunidade representada pelos mini e micro computadores. Com base nesse diagnóstico, recomenda a implementação de políticas para viabilizar um parque industrial de mini e microcomputadores e seus periféricos com total domínio, controle da tecnologia e decisão no país.

Diante da decisão da CAPRE, a maioria dos fabricantes interessados em comercializar os minis no país desistiu da idéia, ou, pelo menos, aguardava ocasião mais propícia para seus planos. Algumas empresas, no entanto, em especial a IBM, deflagraram uma verdadeira guerra de gabinetes tentando impedir a ação da CAPRE, que envolveu carta ao secretário-geral da Secretaria de Planejamento e audiência de sua diretoria internacional com o presidente da república. (HELENA, 1980, p. 92).

Havia ainda na CAPRE algum receio sobre seu poder político para resistir às pressões empresariais e fazer valer as suas recomendações de políticas explicitadas na Resolução 1 de 1976. Para dar maior respaldo às suas decisões e garantir maior legitimidade administrativa para suas ações, buscou-se então o auxílio do CDE. Em janeiro de 1977, este órgão emitiu sua Resolução 5, estabelecendo que a concessão de incentivos fiscais a projetos da área de computação passavam a estar sujeitos à prévia "declaração de prioridade" do Conselho Plenário da CAPRE. Ademais, a Resolução estabelecia critérios que deveriam ser levados em consideração pelo Conselho Plenário para suas decisões, como índice de nacionalização, abertura tecnológica para empresa nacional (no caso de associações com estrangeiras), e origem do capital, ressaltando ainda que esses critérios passariam a valer "para efeito de apreciação dos pedidos relativos a importações de peças, partes e componentes destinados à fabricação de computadores, exigíveis conforme as normas em vigor do Conselho Nacional do Comércio Exterior - CONCEX".

Considerando a nova legislação, a CAPRE recebeu seis projetos para fabricação de minicomputadores no Brasil, solicitando a "declaração de prioridade". Entre essas propostas estava o Sycor 440 da COBRA (comercializado sob o nome COBRA 400), e o 
/32 da IBM. O projeto da COBRA foi brevemente aprovado, recebendo a declaração de prioridade para importação de partes e peças. Já o projeto da IBM foi minuciosamente analisado pelos técnicos da CAPRE, que emitiram um parecer defendendo a sua recusa, por estar em desacordo com os critérios descritos pelo CDE em sua Resolução 05.

Apesar das opiniões expressas no parecer, havia muito receio na CAPRE e no governo federal de que uma resposta negativa para a IBM traria um desgaste político muito grande, além das dúvidas quanto às conseqüências da decisão. Em especial, havia muita pressão para aprovação do projeto, e assim evitar um "monopólio" da COBRA no setor de minicomputadores. Desta forma, depois de várias consultas e reuniões de ministros e membros do Conselho Plenário, chegou-se a uma fórmula conciliatória: realizar uma concorrência para ocupação do mercado, utilizando-se os critérios da Resolução 5 do CDE.

Com base nessa orientação, em junho de 1977 a Secretaria-Executiva da CAPRE publica carta-convite para as empresas interessadas em produzir minicomputadores apresentarem seus projetos. Assim foi lançada a "licitação dos minis", como fícou conhecida. Foi necessário algum trabalho de convencimento do empresariado nacional para a apresentação de propostas, mas ao final 16 empresas submeteram no prazo seus projetos. Dentre essas, 7 eram subsidiárias de empresas estrangeiras, com tecnologia da matriz (IBM, Burroughs, Hewlett-Packard, NCR, Olivetti, Four Phase e TRW), uma associação entre empresa estrangeira e um grupo nacional (Basic-Four e Grupo Lucas Nogueira Garcez), e 8 projetos de empresários nacionais, sendo que dois afirmavam dispor de desenvolvimento interno.

A partir daí os técnicos da CAPRE trabalharam na análise das propostas, em um processo que se pretendia o mais objetivo possível. Em dezembro de 1977 o Conselho Plenário aprova o parecer do grupo de trabalho designado para a avaliação, aprovando os projetos de três grupos nacionais que adquiririam tecnologia estrangeira: a SID (associação formada pela Sharp, Inepar e Dataserv), com tecnologia da empresa francesa Logabax; a Labo Eletrônica, que integrava o grupo Forsa e iria fabricar o equipamento da Nixdorf, alemã; e a Edisa, com os minicomputadores da Fujitsu, considerada a detentora da tecnologia de computação mais avançada entre os fabricantes japoneses. (HELENA, 1977, 34-45). 
Acima desta escolha reside o fato de que a IBM e seu projeto $/ 32$ foram definitivamente descartados, sem a necessidade de uma negativa formal e expressa do governo. A empresa continuaria a apostar no mercado brasileiro, principalmente com seu sistema 4331, que embora fosse de tamanho médio, aproximava-se o suficiente para poder competir com os minicomputadores. (EVANS, 1986, p. 795). Também data desse período a primeira significativa movimentação estrangeira contra a política de informática no Brasil. A empresa americana Data General, que não participou da licitação, enviou uma carta ao governo dos Estados Unidos, afirmando que a política adotada pelos nossos governantes contrariava os interesses das empresas norte-americanas, excluindo-as de um mercado muito promissor, e alertando para o risco de que essa experiência fosse replicada em outras nações em caso de êxito. (TAPIA, 1995, p. 36).

\subsection{A criação da SEI e a nova fase da política}

O período que se inicia com a criação da CAPRE pode ser considerado a primeira fase da política de informática brasileira. Essa fase foi marcada pela luta dos técnicos nacionalistas frustrados e da aliança forjada para criação de uma indústria de informática local. Foi uma luta travada passo a passo, que sofreu a influência de fatores econômicos e políticos internos e externos, e se desenvolveu em um clima de pressões corporativas e discussões de gabinetes. Havia também uma guerra interna travada pelos próprios órgãos do governo, que pretendiam reservar para si parcela do controle sob a política de informática.

Essas características obrigavam os técnicos a se preocupar mais com a sobrevivência do modelo e com os desafios que vinham surgindo do que com sua consolidação e estabelecimento de objetivos de longo prazo. Sob esse aspecto, pode-se considerar que nesse período a política apresentava um forte caráter de fragilidade em seus elementos institucionais.

A fragilidade da CAPRE e da política desenvolvida até então é muito bem representada pela extinção do órgão e conseqüente fim dessa primeira fase. Conforme já mencionado, essa política era calcada no nacionalismo e nos interesses e concepções ideológicas de diferentes grupos que se uniram para viabilizar a pesquisa e proteção da computação interna. Tratava-se de uma aliança politicamente frágil e sempre marcada pela desconfiança mútua. Toda essa fragilidade é exposta com a mudança do governo militar 
em 1979, levando ao poder um presidente com passagem pelo Sistema Nacional de Informação - SNI. Este órgão, juntamente com o Ministério das Relação Exteriores - MRE, passou a desconfiar daquele conjunto de técnicos e universitários que pareciam ter o controle de uma área que se revelava cada vez mais estratégica para o setor de informações e comunicações diplomáticas.

A CAPRE passava então por um momento de conflito interno. Após a derrota no episódio dos minis, a IBM decidiu renunciar à confrontação direta com o governo, e, com um tom mais ameno, procurou negociar a aprovação de novos projetos cobrindo todas as faixas de mercado imediatamente acima. Assim, apresentou à CAPRE cinco novos projetos de máquinas de diferentes tamanhos, ${ }^{14}$. Resistindo à pressão da comunidade científica e dos empresários locais, o Conselho Plenário aprova no final de 1978 os modelos de maior porte. Diversas críticas foram levantadas contra a CAPRE por esta decisão, inclusive por membros internos da comissão. Além desse episódio, a CAPRE também se dedicava a costurar uma associação entre SERPRO, DIGIBRÁS e a Fujitso, para o lançamento de um concorrente a IBM no mercado dos médios. É certo, mais uma vez, que havia correntes contrárias a tal associação, com base no argumento de que o capital, tal como no caso dos minis, deveria ser inteiramente nacional. (HELENA, 1980, p. 101).

Paralelamente a esses problemas internos, em 1979 emergem os interesses de alguns atores políticos que até então tinham permanecidos alheios a essa história: o SNI e o MRE. Os dois órgãos há tempos tinham problemas e preocupações com a transmissão de suas informações. O SNI, órgão por excelência de informações e inteligência do governo, era completamente defasado em tecnologia digital e de comunicação. O MRE, por sua vez, estava encontrando problemas com a falta de integridade e segurança nas comunicações com suas embaixadas e demais órgãos espalhados pelo globo. (DANTAS, 1988, pp. 106108).

Era uma situação desconfortável para os dois órgãos. Em 1977, eles decidem trabalhar conjuntamente em um projeto sigiloso para desenvolver um equipamento de cifração de comunicações, o Projeto "Prólogo". Apesar de excelentes resultados, o projeto

\footnotetext{
${ }^{14}$ Denominadas Leblon-1, Leblon-1 expandido, Leblon-2, Leblon-2 expandido e Ipanema. (HELENA, 1980, p. 101).
} 
revelou que o problema de desenvolver uma máquina criptográfica não era diferente daqueles enfrentados pelos equipamentos de informática, a dependência de componentes e tecnologia externa. A conclusão dos responsáveis pelo projeto foi a de que ter capacidade de projetar as máquinas "não era suficiente para garantir autonomia tecnológica". (TAPIA, 1995, p. 47). Considerando essa conclusão, o SNI e o MRE passam a olhar com maior atenção para os rumos do setor de informática. Desconfiados da condução da política realizada pela CAPRE, no final de 1978 nasce uma Comissão composta por esses dois órgãos e financiada pelo CNPq para estudar a situação da informática do país. A comissão ficaria conhecida pelo membro participante do MRE, o embaixador Cotrim. Trabalhando de maneira sigilosa, a Comissão Cotrim entregou seu relatório em maio de 1978, no qual tecia severas críticas a CAPRE e a sua atuação. "Não existe uma política de tecnologia da informação no Brasil. Não há, conseqüentemente, um órgão que se ocupe, de forma centralizada, do apoio a sua formulação e execução. Há grande desperdício nessa área, com o fracionamento informal de atribuições entre muitos órgãos e a tomada de decisões descoordenadas e até conflitantes”. (HELENA, 1980, p. 106).

Acatando proposta da Comissão Cotrim, o governo Figueiredo, em uma de suas primeiras medidas, publica o Decreto 83.444, de 10.5.1979, no qual institui um novo Grupo de Trabalho Especial - GTE, para estudar e propor sugestões específicas com vistas à reestruturação dos órgãos envolvidos no setor de informática e à formulação de uma política global de informática (artigo $1^{\mathrm{o}}$ do decreto). O GTE entregou seu relatório em setembro do mesmo ano, apontando incoerências e contradições na política, e sugerindo a criação de um novo órgão responsável pelo setor, que não deveria estar sujeito a diversos ministérios (caso da CAPRE), passando a estar vinculado diretamente ao CSN. (DANTAS, 1988, pp. 121-122).

As sugestões do GTE foram de pronto acatadas pelo novo governo, que em outubro do mesmo ano edita o Decreto 84.067/79, extinguindo a CAPRE e criando a Secretaria Especial de Informática - SEI, órgão complementar do Conselho de Segurança Nacional CSN. Sua principal atribuição seria auxiliar o CSN na formulação de uma Política Nacional de Informática, e coordenar sua execução, como órgão supedrior de orientação, planejamento, supervisão e fiscalização, tendo em vista, especialmente, o desenvolvimento científico e tecnológico no setor $\left(\operatorname{art} 1^{\circ}\right)$. 
$\mathrm{Na}$ análise comparativa da estrutura funcional e conjunto de atribuições da CAPRE e da SEI é forçoso reconhecer que esta representou um aprofundamento daquela, absorvendo-se a herança e melhorando-a no que se entendia necessário. Da mesma forma que a CAPRE, a SEI tinha um órgão colegiado, que era a Comissão de Informática CI/SEI. Esta comissão tinha, entretanto, um corpo mais abrangente do que o antigo Conselho Plenário (incluindo obviamente representantes do MRE e do CSN), podendo contar inclusive com 4 membros do setor privado. No que tange às competências, a SEI recebeu um número muito superior ao imaginado para a CAPRE (o artigo $5^{\circ}$ do Decreto 84.067/79 lista 33 atribuições da SEI, enquanto o Decreto 77.118/76 tinha apenas 5 itens de competência da CAPRE).

As verdadeiras conseqüências da criação da SEI e de sua atuação seriam sentidos posteriormente. Entretanto, pode-se perguntar qual foi o real significado, naquele momento, da extinção da CAPRE e sua substituição pela secretaria. Acredito que, dentre outros fatores, esse movimento representou duas tendências que, embora contraditórias, estavam presentes neste caso, que são o aprofundamento e a concomitante ruptura do modelo anterior.

O aprofundamento refere-se à militarização da política de informática, representada por sua completa submissão ao CSN, que teve como conseqüência prática a sua incorporação à agenda prioritária do núcleo duro do regime autoritário. O setor passou a ser prioridade do governo, e a formulação e implementação das ações estatais passaria a ser feitas por órgãos dotados de extremo prestígio e poder na estrutura administrativa. (TAPIA, 1995, p. 47). Passando a ser setor estratégico, a SEI ganhou uma autoridade que vai livrá-la de alguns dos questionamentos e desafios sofridos pela CAPRE em seu momento inicial, embora isso não tenha significado de forma alguma o fim dos conflitos envolvendo a política de informática.

Já a ruptura do modelo refere-se ao término da aliança que deu sustentação à CAPRE na década de setenta. A partir da SEI, o quadro de forças políticas é alterado, e os técnicos nacionalistas frustrados são alijados do processo decisório. Não havia mais espaço para os "guerrilheiros tecnológicos", e os militares passaram a dominar os rumos da política, ainda que precisassem contar com o apoio de técnicos. Conforme Evans, a reestruturação do pessoal administrativo foi completa, e apenas sete dos quarenta membros 
que trabalhavam na CAPRE foram aproveitados na nova secretaria, e mesmo assim em posições de pouca relevância. (EVANS, 1986, p. 796). A COBRA e a DIGIBRÁS também sofreram intervenções em seus quadros ${ }^{15}$.

\subsection{A atuação inicial da SEI, a licitação dos superminis e a Lei de Informática}

Com a criação da SEI, pela primeira vez um conjunto de diretrizes coerentemente formuladas como uma política de informática foi institucionalizado pelo governo. Isso era esperado na medida em que uma das principais críticas da Comissão Cotrim e do GTE à CAPRE era a inexistência de uma política articulada e que evitasse contradições e desperdícios de recursos. Embora não conste propriamente do decreto criador da SEI, mas de sua exposição de motivos, esse documento, chamado "Diretrizes para a política nacional de informática", norteou a ação da SEI e é mencionado em pelo menos um ato normativo do órgão (Ato Normativo $n^{0} 001 / 80$ ).

Apesar de criada em outubro de 1979, a SEI começou a funcionar mesmo em fevereiro do ano seguinte. (SEI, 1980, p. 2). Sua estrutura administrativa foi definida pelo Decreto 84.266/79, e, além da referida CI/SEI, havia ainda um Gabinete, as assessorias setoriais, a secretaria-executiva, com cinco subsecretarias, e comissões especiais de caráter temporário (artigo $3^{\circ}$ e seguintes do decreto). Dispondo de maior estrutura e mais atribuições e competências, a SEI passou a atuar com maior freqüência e abrangência do que a CAPRE. Isso é especialmente sentido no conjunto normativo expedido pelo órgão, que é substancialmente superior (só em 1980 foram 10 Atos Normativos, além das Portarias expedidas pelas Comissões Especiais).

O conjunto de instrumentos de política utilizados também é ampliado. Com base no decreto de criação da SEI, não me parece exagerado afirmar que este órgão tinha competência para controlar ou se manifestar sobre grande parte do que dizia respeito ao setor de informática no país, incluindo a regulamentação de profissões, pedidos de patente, normas técnicas e padrões, averbação de contratos no INPI e incentivos fiscais (Decreto 84.067/79, artigo $5^{\circ}$ ). Com base neste rol de competências e em seus atos normativos, a SEI pôde explicitar o controle de importações e a reserva de mercado (Ato Normativo 1/80). A proteção às empresas nacionais foi posteriormente ampliada de forma a abranger

\footnotetext{
${ }^{15}$ Essa história é contada por DANTAS, 1986, capítulo 9, pp. 106-126.
} 
outros setores tais como microcomputadores, controle de processos, circuitos integrados digitais, instrumentação e, posteriormente, aos supermínis. (PIRAGIBE, 1985, p. 132).

O primeiro atrito entre a SEI e a indústria de informática ocorreu logo no primeiro ano de sua existência, quando a IBM reapresentou seu projeto para o médio 'Leblon 1'. Em uma decisão da cúpula do órgão, o projeto foi aprovado, e a SEI se tornou alvo de diversas críticas das empresas e associações do setor, tendo que reconhecer seu erro e voltar atrás na decisão ${ }^{16}$. Outros dois episódios relevantes desse período revelariam as divergências entre a SEI e a indústria nascente, expondo alguns pontos de contradição do setor. Tratam-se da licitação para fabricação dos chamados 'superminis', e a ascensão da política de informática ao nível legal em 1984.

$\mathrm{O}$ caso da licitação dos superminis ${ }^{17}$ é importante por ter colocado à prova pela primeira vez a política e reserva de mercado implantada pela CAPRE, e por trazer à tona as diversas posições a respeito da continuidade da política, não só dentro do governo como também na indústria, demonstrando o setor ter atingido alguma complexidade que admitisse interesses e propostas divergentes.

No final de 1982 a SEI publica o Comunicado 7/82, no qual convocava a indústria nacional para apresentação de projetos de fabricação de supermínis. A SEI tinha três alternativas para implementar a política dos superminis: desenvolvimento próprio, formação de joint ventures, e licenciamento de tecnologia. Os defensores do 'antigo modelo' da CAPRE eram favoráveis à primeira opção, mas os policy-makers da SEI estavam dispostos a fazer concessões e permitir o licenciamento de tecnologia. (ADLER, 1986, 699).

Parte do empresariado nacional reagiu contra a convocação da licitação. Essas empresas colocavam em dúvida a viabilidade de mercado dos superminis, seja pelos riscos de obsolescência, seja pelos riscos da IBM aproveitar sua base instalada para avançar sobre

\footnotetext{
${ }^{16}$ Essa história é contada por DANTAS, 1986, capítulo 10, pp. 140-142.

17 Conforme Tigre, os superminis podem ser considerados um desenvolvimento dos anteriores minicomputadores. Foram criados porque este segmento estava perdendo a concorrência com os equipamentos menores, os microcomputadores. A estratégia de mercado adotada passou a ser competir com equipamentos maiores, os mainframes. Para isso, os superminis utilizavam microprocessadores melhores, conseguindo oferecer a capacidade de um mainframe por um preço pouco superior aos minis (ver TIGRE, 1987, p. 16).
} 
as faixas dos superminis. Questionavam a decisão da SEI porque, ao acenar com a possibilidade de licenciamento de tecnologia, a secretaria agia em contradição com um dos principais objetivos da política: a capacitação tecnológica nacional. (TAPIA, 1995, p. 64). Após diversas discussões e prorrogações do prazo inicial, em outubro de 1983 a SEI recebeu oito projetos, sendo três com tecnologia própria e cinco prevendo o licenciamento de conhecimento externo. No início do ano seguinte, a SEI aprova apenas os projetos de desenvolvimento de tecnologia própria, mas, cedendo às pressões, passa a admitir a possibilidade de aprovação dos demais desde que as empresas se associassem ou se fundissem. O objetivo claro era a criação de grupos com maior porte técnico e comercial para aproveitamento de economias de escala, até mesmo para viabilizar as negociações com parceiros estrangeiros.

A estratégia não deu certo. A idéia de concentração de mercado foi rejeitada tanto pelos grupos econômicos fortes quanto pelas empresas menores. Ninguém via real vantagem nas fusões propostas pela SEI. Vendo seus planos naufragarem e sofrendo diversas pressões de vários lados, o órgão mais uma vez é obrigado a voltar atrás em suas decisões. Em junho de 1984 anuncia que seriam aprovados todos os projetos apresentados para fabricação de superminis.

Ao contrário de encerrar as controvérsias, essa nova decisão trouxe novas críticas. A aprovação de todos os projetos com tecnologia estrangeira implicaria que as três empresas com projeto próprio já aprovados teriam que buscar também parceiros estrangeiros, caso contrário sofreriam um grande revés. Na prática, a SEI revogava a decisão anterior e optava definitivamente pelo licenciamento de tecnologia. Houve reações de diversos setores. Os defensores do nacionalismo tecnológico enviaram uma mensagem à SEI, na qual consideravam a decisão um retrocesso em relação à luta pela obtenção de autonomia tecnológica na área de computação. (TAPIA, 1995, pp. 71-72).

A concorrência dos superminis revelou algumas falhas da política de protecionismo e de reserva de mercado. O afastamento progressivo da SEI de sua proposta inicial de fazer o 'salto tecnológico' para os superminis com base em projetos nacionais reflete isso. Dois pontos são relevantes e devem ser destacados: as dificuldades das empresas nacionais em elaborar projetos viáveis em termos de tempo e de confiabilidade tecnológica indicavam os resultados modestos da capacitação obtida a partir do licenciamento da tecnologia dos 
minicomputadores em 1977 e a falta de porte financeiro e organizacional das empresas locais; e a percepção crescente de que a base empresarial inicial era muito frágil para os ambiciosos planos de criar uma indústria de informática nacional diversificada, competitiva, num prazo de tempo bastante curto. (TAPIA, 1995, p. 73).

O outro episódio citado como relevante para compreender esse momento da SEI e da política de informática é o debate no Congresso Nacional para a aprovação da lei com os marcos da política e seus objetivos. As discussões no âmbito desse debate constituem um dos mais interessantes momentos dessa história. Nunca foram tão polarizadas as posições a respeito da ação governamental sobre o setor. Ademais, é uma história que não se resume à discussão sobre a informática. Ela não pode ser compreendida fora de seu momento histórico e político, sem o contexto da redemocratização do país e do ocaso do regime autoritário.

O elemento principal que iniciou esse processo de discussão foi a abertura política no início da década de oitenta. Se a SEI tinha a seu favor maiores poderes para agir do que a CAPRE, ela tinha também que lidar com uma atmosfera política na qual os opositores do regime podiam e começavam a expressar seu descontentamento. Assim, os descontentes com a política de informática ${ }^{18}$ viram o momento para atacar a SEI e seu protecionismo como ineficiente e retrógrado.

Uma figura central desse processo foi o economista, diplomata e senador eleito em 1982 pelo Estado do Mato Grosso, Roberto Campos. Campos utilizava de todos os argumentos e expressões para criticar a política protecionista e seus defensores, conseguindo reunir um bom número de desafetos e debatedores. Campos, aliás, nunca se cansou de falar mal da política de informática dos anos oitenta. Mesmo após o seu término, ele escreveu outros textos denunciando as mazelas dessas medidas e pouco disposto a reconhecer-lhes méritos. Dizia que foi um momento de 'férias coletivas da razão'. (CAMPOS, 1999).

\footnotetext{
${ }^{18}$ Conforme Tapia, (1995, pp. 89-90), esse grupo era principalmente composto por empresários nacionais não ligados ao setor de informática, empresas do setor de eletrônica de consumo, empresas do setor de telecomunicações, usuários de bens de informática e empresas de serviços neste setor. Seus interesses eram representados pela FIESP, CNI, ABINEE, ASSESPRO e SUCESU. No âmbito governamental, a oposição vinha em grande parte dos Ministérios das Comunicações e da Indústria e Comércio, além da Superintendência da Zona Franca de Manaus.
} 
A política foi atacada interna e externamente. No plano interno, além das multinacionais, que tinham motivos óbvios para manter sua posição, boa parte do empresariado nacional ligado a outros setores industriais também começou a reagir. A FIESP divulgou documento afirmando que a posição de fechamento na área de informática poderia comprometer o 'futuro industrial do país' e aumentar ainda mais o hiato com países desenvolvidos. (TAPIA, 1995, p. 81). No plano externo, os Estados Unidos passaram a tomar uma atitude mais ofensiva na defesa de suas empresas, criticando abertamente o protecionismo brasileiro.

Por fim, mas não menos importante, havia o fato de a SEI ser um braço do CSN, órgão amplamente identificado com o regime militar. Se, por um lado, isso lhe garantia prestígio e maior poder decisório, por outro, a associação entre a SEI e o autoritarismo tornou-se inevitável. Os opositores da política aproveitaram-se largamente desse fato, acusando a reserva de mercado de ser instrumento autoritário e não democrático de política pública.

Para os membros da SEI e toda a comunidade de informática, ficou claro que a política estava ameaçada. A crítica de autoritarismo deveria ser superada, e a forma adequada de realizar isto era legitimar a política através de sua aprovação no Congresso Nacional como lei. Conforme Dantas, o movimento pelas eleições diretas para Presidente da República havia ganho as ruas e o Congresso. No bojo do processo de redemocratização, a necessidade de se ampliar o debate sobre a política de informática era uma conseqüência lógica. Com o fim do regime, todo o arcabouço da política, sustentado em decretos e atos normativos da SEI, poderia ruir por força do novo governo civil. Para a sua própria sobrevivência, a política de informática deveria deixar a esfera militar. (DANTAS, 188, p. 155).

Gradativamente, o movimento nacionalista foi se ampliando e incorporando os partidos políticos que praticamente não tinham expressão na discussão da política brasileira de informática. Em 1983 o senado federal realiza seu I Simpósio de Informática, do qual participam a grande maioria dos partidos políticos e associações do setor, reconhecendo a importância da reserva de mercado e da necessidade de institucionalizá-la e legitimá-la como lei aprovada pelo poder legislativo. 
Tapia dá notícias de ao menos cinco projetos de lei acerca do assunto tramitando no Congresso Nacional durante esse período. (TAPIA, 1995, p. 84). O primeiro deles foi apresentado pela deputada Cristina Tavares, documento curto ( 8 artigos), elaborado às pressas devido ao anúncio da SEI de que estaria elaborando sua própria proposta para a política. No final de julho de 1984 o governo do presidente Figueiredo apresentou o projeto formulado e defendido pela SEI. A primeira grande novidade foi a sua submissão como projeto, e não como Decreto-Lei. Pretendia-se preservar o debate e evitar a 'pecha' de autoritarismo da política de informática. Este projeto mantinha grande parte da estrutura institucional então vigente. $\mathrm{O}$ grande elemento novo era o estabelecimento de um prazo final para a reserva de mercado, negociado em oito anos com o então ministro Delfim Netto. (DANTAS, 1988, P. 162).

Houve intenso debate sobre os projetos, com grande mobilização da comunidade técnica e sociedade civil. Grandes divergências impediam um acordo sobre a legislação a ser votada. Um desses pontos era a natureza do órgão encarregado de formular e implementar a política. Discutia-se se a SEI e a futura Comissão de informática deveriam estar ligados ao CSN, à Presidência da República ou a algum ministério. A SEI e o CSN defendiam que sim, fundamentados no argumento de que informática era um tema de segurança nacional, devendo portanto ficar submetida ao órgão administrativo responsável por formular políticas estratégicas. Já o PMDB e as outras forças civis eram favoráveis a sua passagem para as mãos dos civis, baseados principalmente em críticas sobre o autoritarismo da SEI.

A eleição presidencial então em curso também teve forte influência nessa disputa. Os dois candidatos tomaram posições antagônicas, e isso aumentou o viés político da discussão, que transcendeu os limites técnicos e econômicos da política de informática. $\mathrm{O}$ candidato da oposição, Tancredo Neves, incorporou à sua plataforma eleitoral a defesa da reserva de mercado na informática como parte da luta da sociedade brasileira contra o autoritarismo e pela redemocratização. $\mathrm{O}$ apoio de Tancredo permitiu desvincular a reserva de mercado e a política como instrumentos autoritários. Por outro lado, Paulo Maluf, embora buscando um equilíbrio para não hostilizar uma idéia que parecia conquistar cada vez mais adeptos no Congresso, acabou defendendo a adoção de políticas tarifárias como mecanismo de proteção às indústrias de informática e se disse favorável à formação de joint-ventures entre empresas nacionais e estrangeiras. (DANTAS, 1988, p. 169). 
Após diversas discussões chegou-se a uma composição e foi aprovado com algumas alterações o projeto substitutivo do relator, senador Virgílio Távora. A Lei 7.232/84 desmilitarizou a SEI e o CONIN, que passaram a estar subordinados à Presidência da República. Diversos instrumentos de política foram previstos abrangendo mais áreas da indústria informática, incluindo "o controle das importações de bens e serviços por 8 (oito) anos" (artigo $4^{\circ}$, VIII). No fim, depois de tanta polêmica e mobilização de setores sociais, obteve-se um consenso relativamente amplo em torno do texto, garantindo a aprovação do projeto.

Dessa forma a política nacional de informática, que até então havia se baseado em atos normativos, portarias e resoluções de órgãos diversos, ganhou respaldo legislativo. Os efeitos dessa institucionalização, no entanto, foram de ordens diversas. A política agora não poderia ser negada, a reserva estava explícita em texto legal, o que facilitava o trabalho de seus opositores, em especial nas contestações que já vinham sendo feitas pelo governo norte-americano. (TAPIA, 1995, pp. 111-112).

2.8 Pressões externas: a disputa comercial com os Estados Unidos sobre a política de informática

Em 7 de setembro de 1985 o presidente norte-americano Reagan fez um anúncio de que os Estados Unidos iriam solicitar ao United States Trade Representative - USTR a abertura de um processo para investigar a política brasileira com relação à informática, baseado na Section 301 do Trade $A c t^{19}$. Iniciou-se então um período de disputas e discussões diplomáticas, com pressões e ameaças de retaliações comerciais que durou cerca de três anos. Além de algumas vitórias no campo institucional para os interesses norte-americanos, essa disputa apresenta especial relevância por trazer a um novo patamar as críticas à reserva de mercado e à política brasileira. Seus opositores passaram a contar com argumentos mais solidamente construídos pelas autoridades diplomáticas americanas,

\footnotetext{
${ }^{19}$ A Section 301 é uma legislação de direito interno dos Estados Unidos datada de 1962 e posteriormente alterada em 1974 e 1988. Em linhas gerais, ela dá poderes ao presidente para realizar retaliações comerciais contra um país estrangeiro, caso o USTR, após um procedimento investigatório, declare que (a) algum direito dos Estados Unidos estabelecido em um tratado internacional não está sendo observado, ou (b) algum ato, política ou prática de outro país viola ou nega aos Estados Unidos benefícios comerciais acordados em tratado ou injustificavelmente onera ou restringe o comércio norte-americano. A esse respeito ver BELLO E HOLMER, 1988, p. 1198.
} 
e com a pressão externa da maior potência econômica para o encerramento do protecionismo à indústria e tecnologia local.

Já fazia algum tempo que o governo dos Estados Unidos acompanhava atentamente o desenrolar da política de informática brasileira, em especial no que se referia aos interesses de suas indústrias. Durante a discussão da Lei 7.232/84 no Congresso Nacional, o departamento de comércio publicou documento alegando que a postura brasileira era 'anti-americana'. Os norte-americanos também chegaram a fazer uma consulta formal às autoridades do GATT sobre a adequação da legislação brasileira aos princípios do acordo internacional. (TAPIA, 1995, p. 177).

Os motivos para explicar a ofensiva dos Estados Unidos contra a política de informática brasileira estariam principalmente relacionados à alteração dos termos da balança de comércio entre os países, que passaram em seis anos de um déficit brasileiro para um superávit de mais de 5 bilhões de dólares. Tendo em vista esse novo cenário, o presidente Reagan tinha suficiente embasamento para questionar qualquer medida protecionista que afetasse os interesses de empresas americanas no Brasil.

Além da discussão sobre a política de informática, um tema central da discussão entre os dois países foi a legislação brasileira sobre software. A orientação adotada pela CAPRE no final dos anos setenta e ratificada depois pela SEI sublinhava "a importância de proteger e promover a emergência de uma indústria local de software, com ênfase na produção e comercialização de pacotes”. Todavia, apesar do reconhecimento da importância da indústria e das recomendações feitas por comissões criadas no nível governamental, o setor continuou sem regulamentação até 1988. As exigências do governo norte-americano com relação a este assunto eram principalmente a adoção de uma legislação clara e específica, não adotando a reserva de mercado e medidas protecionistas para este setor, estabelecendo o regime de direito autoral (copyright), e prevendo ainda regras claras para o combate à clonagem e pirataria de software.

A reação no Brasil ao anúncio do presidente Reagan e ao início dos procedimentos no USTR foi de indignação e recrudescimento das posições nacionalistas. O governo, os empresários, as entidades científico-profissionais rechaçaram com veemência as ameaças norte-americanas. Como o governo brasileiro não apresentou qualquer resposta formal, a 
Associação Brasileira de Computadores e Periféricos - ABICOMP, através de um escritório de advocacia norte-americano, apresentou um documento com argumentos de defesa à política de informática. Dentre os pontos apresentados vale destacar a menção ao artigo 18 do GATT, que estabelece o direito dos países de, em determinadas circunstâncias, tomar medidas de proteção para desenvolvimento de determinado ramo industrial ou agrícola ${ }^{20}$.

No início de 1986 o Brasil aceita discutir o caso, desde que baseado nas regras do GATT (rejeitando assim o Trade Act norte-americano). Em fevereiro deste ano, ocorre a primeira reunião oficial sobre o assunto em Caracas. A delegação americana expôs os seus principais pontos sobre o fim da reserva de mercado e a adoção do regime de direito autoral para software. (EVANS, 2004, p. 225). A situação se complica em abril daquele ano com a promulgação da Lei 7.463, que aprova o I PLANIN. Elaborado pelo CONIN, o plano ratifica e explicita os termos da política nacional e informática da Lei 7.232/84, reconhecendo seus méritos e admitindo a necessidade de alguns aprofundamentos.

Seguindo-se algumas discussões e ameaças de retaliações pelos Estados Unidos, até junho de 1987 foram obtidos certos avanços, envolvendo concessões brasileiras: (a) o país aceitou não estender a lei após 1992 e não aplicá-la em outros setores; (b) a Câmara dos Deputados aprovou o projeto de lei do software estabelecendo o regime de direito autoral; (c) o Brasil fez melhorias na administração da SEI; (d) o país concordou ainda com a publicação de uma lista negativa de produtos não sujeitos à reserva; e (e) houve maior flexibilidade na restrição aos investimentos externos, sendo permitidas algumas associações entre empresas locais e estrangeiras. (TAPIA, 1995, p. 192). À luz desses desenvolvimentos, os Estados Unidos decidiram encerrar suas reclamações com relação ao software, postergando as negociações referentes aos demais temas.

\footnotetext{
${ }^{20}$ Nota-se, no entanto, que esse artigo exige notificação às demais partes do acordo, que devem se manifestar a respeito e decidir sobre as medidas propostas. A primeira versão do Acordo Geral sobre Tarifas Aduaneiras e Comércio foi aprovado e internalizado no direito brasileiro pela Lei 313 de 30 de julho de 1948 . O seu artigo XVIII - Ajustes relativos ao desenvolvimento econômico, reconhece que "no caso de certos ramos de atividade industrial e agrícola, pode ser necessário, para facilitar o seu estabelecimento, desenvolvimento ou reconstrução, fazer apêlo a um auxílio especial do Estado e que, em certas circunstâncias, a concessão dêsse auxílio sob a forma de medidas de proteção é justificável" (item 1). Assim, se um país parte do acordo desejar utilizar dessas medidas, deverá notificar as demais partes, que analisarão e decidirão sobre a aprovação das medidas, conforme o procedimento estabelecido no mesmo artigo XVIII.
} 
O clima pacífico das negociações foi abalado por duas circunstâncias envolvendo empresas norte-americanas que até o momento tinham ficado à margem da discussão da política de informática brasileira: a SEI indeferiu o pedido de seis empresas brasileiras para licenciamento do sistema operacional MS-DOS, da Microsoft, sob a alegação de existência de um similar nacional (o Sisne, da Scopus); e aumentaram as chances da secretaria aprovar o projeto de fabricação de um clone do equipamento MacIntosh, da Apple, chamado MAC 512. A resposta norte-americana a essas medidas foi agressiva, e em novembro foram anunciadas medidas de retaliação comercial no valor de 105 milhões de dólares. (EVANS, 2004, p. 231).

O governo brasileiro mais uma vez realizou algumas concessões e solucionou os pontos principais da disputa. O CONIN reconsiderou o veto ao MS-DOS, argumentando que não havia no país um similar nacional, não havendo portanto impedimentos à comercialização. A SEI, por sua vez, deixou claro que para a aprovação do MAC 512, a empresa responsável teria que comprovar o 'desenvolvimento autônomo' do produto. E, por fim, em dezembro daquele ano foi promulgada a esperada lei de software, Lei 7.646/87, que, embora admitisse o regime de direito autoral (art. $2^{\circ}$ ), restringia o prazo de tutela a 25 anos, e exigia o cadastro do programa na SEI para sua comercialização (art. $8^{\circ}$ ).

A crise diplomática encerrou-se finalmente em junho de 1988, quando o governo norte-americano decidiu suspender as investigações, e comunica oficialmente o governo brasileiro a respeito.

Quais as conseqüências efetivas da discussão com os Estados Unidos sobre a política de informática? Uma primeira análise revela claramente uma disparidade entre o "barulho" feito, todas as reuniões e ataques mútuos, e os resultados práticos ao final do processo, em especial no plano do direito interno brasileiro. No campo institucional, pouco pode ser considerado reflexo desse debate. A exceção fica para a adoção do direito autoral no campo do software, embora nem isso tenha sido uma vitória completa dos Estados Unidos, uma vez que a SEI permaneceu com a prerrogativa de conceder ou negar o cadastro de programas para sua comercialização no país. Quanto à Lei de Informática, pouco ou nada efetivamente mudou, a reserva de mercado foi mantida no seu prazo inicialmente previsto e os poderes decisórios permaneceram com a SEI e o CONIN. Evans, inclusive, identifica resultados antagônicos no que tange a perspectiva institucional. Para o 
autor, o caso colaborou para incitar na população e nos parlamentares um sentimento nacionalista e de proteção contra os países desenvolvidos, o que teria sido refletido na Constituição Federal de 1988, em especial no que tange as normas ligadas ao capital externo. (EVANS, 2004, p. 233).

A impressão que fica é que a grande conseqüência ficou no campo político, em especial na articulação das forças contrárias à política de informática. A disputa teria reforçado as posições das forças internas contrárias à política de informática, aumentando sua legitimidade e reduzindo a capacidade da SEI de implementar as diretrizes definidas na Lei 7.232/84. Com efeito, houve o reforço e ampliação dos interesses burocráticos e industriais alinhados contra a política de informática. Assim, na esteira da disputa, a oposição fortalecida centrou suas críticas em dois pontos: na reserva de mercado e na justificativa do desenvolvimento tecnológico local. (TAPIA, 1995, pp.222-223).

Deve-se lembrar também que o contexto econômico que o país vivia no final da década de oitenta não era dos mais fáceis. A crise da dívida, a inflação crescente e os planos econômicos fracassados legitimavam as críticas contra qualquer política pública na área econômica, e o setor de informática não estava ileso a elas. A política de informática chega ao final da década de oitenta sem contar com o apoio que tinha em seu início, até a promulgação da Lei 7.233/84. Com suas bases minadas pelas disputas e ataques internos e externos, o caminho estava aberto para sua extinção completa no início da década seguinte.

\subsection{A superação da antiga política nacional de informática}

Nesta última parte desta narrativa tentarei reconstruir em breves linhas as circunstâncias políticas e econômicas que levaram ao abandono da estratégia desenvolvimentista para o setor que vigorava, no mínimo, desde 1977. O final da década de oitenta e início da década seguinte foram momentos de transição em diversos sentidos para várias economias e sistemas políticos. O cenário internacional nesse período foi marcado por um movimento cada vez mais intenso do fluxo de capitais e transformação tecnológica, ainda que as dificuldades associadas a um ambiente macroeconômico interno instável não permitissem à economia brasileira plena participação nesses movimentos ${ }^{21}$.

\footnotetext{
${ }^{21}$ Para uma melhor análise do período ver BAUMANN, 1999, pp. 11-99.
} 
Considerando esse quadro, vou argumentar que os seguintes elementos foram centrais para explicação dos rumos tomados pela política de informática: em primeiro lugar, o momento de ascensão e apogeu da chamada ortodoxia econômica, com um discurso de abertura econômica e de política industrial restrita (o que foi apresentado como o neoliberalismo ou neo-utilitarismo no capítulo anterior, ou mesmo a $3^{\text {a }}$ fase das idéias sobre desenvolvimento - o "Consenso de Washington", conforme David Kennedy); e a composição e as orientações empresariais assumidas pelos principais grupos do setor, em especial no tocante ao seu relacionamento com o capital externo. Quanto aos resultados e problemas enfrentados pela política no final da década de oitenta, deixarei para mencionálos no próximo item, quando discutirei os aspectos econômicos e a indústria de informática brasileira ao final do período da reserva.

O primeiro elemento, que chamei de ascensão da ortodoxia econômica, pode ser entendido como uma alteração no clima ideológico e alteração no rumo de estratégia de desenvolvimento industrial adotada no Brasil. Questionamentos de diversas ordens levaram à saturação do modelo desenvolvimentista baseado no protecionismo e em medidas de política industrial abrangente, em favor de entendimentos pregando uma atuação mais pontual do Estado para correção de falhas de mercado e estabelecendo um contexto institucional favorável aos negócios. Segundo esse diagnóstico, o Estado teria perdido o caráter de ator principal, assim como sua capacidade de formular e implementar políticas públicas. Esse quadro seria fortemente agravado pela crise que abalou a economia brasileira nos anos oitenta. Problemas de ordem fiscal, de pagamento de dívidas e uma forte tendência inflacionária exigiam esforços do Estado numa perspectiva macroeconômica e colocavam em xeque sua habilidade para políticas voltadas à promoção do desenvolvimento. Conforme Bresser Pereira, esta crise caracterizava-se pela crise fiscal, expressa em poupança pública negativa e em aumento do endividamento público, em crise da forma de intervenção do Estado - o esgotamento do modelo de substituição de importações, e em crise da forma burocrática e ineficiente de administrar o Estado. (BRESSER PEREIRA, 2003, P. 247).

No plano internacional, essa guinada para um modelo de Estado menos intervencionista vai se completar no início da década seguinte, com o que convencionalmente se chamou de 'Consenso de Washington'. O principal documento que 
sintetizou esse conjunto de idéias e recomendações de políticas para os estados foi o artigo de Williamson “What Washington means by policy reform?”. (WILLIAMSON, 1990).

É importante destacar que no Brasil essa perspectiva de atuação estatal somente vai se concretizar em maior profundidade a partir do governo seguinte, no início dos anos noventa. Entretanto, já no governo Sarney essas idéias passaram a questionar o intervencionismo estatal vigente, com repercussões sobre a política de informática. A nova orientação é bem retratada pela Nova Política Industrial - NPI lançada por este governo em 1987. Segundo a NPI, no cenário internacional ocorriam importantes transformações nas características do comércio internacional sob o influxo da nova revolução tecnológica mundial, cuja conseqüência era a erosão das velhas vantagens comparativas baseadas nas matérias-primas e nos baixos custos da força de trabalho. O discurso da NPI advogava medidas visando atrair o capital estrangeiro, desregulamentar a atividade econômica e facilitar a importação de novas tecnologias. A NPI contemplava também a supressão das barreiras à importação, com o resgate das tarifas aduaneiras em seu papel de principal instrumento de regulação do nível concorrencial da indústria - o estímulo às exportações visava obter saldos comerciais e induzir à modernização da indústria. (TAPIA, 1995, p. 233-234).

O segundo elemento a ser destacado é o que Tapia chamou de 'redefinição do quadro de lealdades do mercado'. Trata-se, em verdade, de alterações nas estratégias de negócios e de relacionamento adotadas por atores privados nacionais e estrangeiros. Esses grupos passaram a agir de maneira cooperativa, fechando acordos comerciais de diversos tipos para atuação conjunta no mercado interno. Tais novas estratégias levaram esses atores a acirrar suas críticas e posições contrárias à política de informática, o que acabou por fim minando ainda mais sua base de sustentação no empresariado.

Desde o início da política até meados dos anos oitenta, as relações entre os grupos nacionais e as indústrias multinacionais eram bastante restritas, especialmente pelas proibições estabelecidas pelos órgãos governamentais. O modelo de política pretendia a construção de uma capacidade interna de pesquisa e produção, baseada na autonomia tecnológica das empresas nacionais. Essas deveriam ser capazes de desenvolver suas próprias pesquisas e gerar inovações, baseadas unicamente em seus recursos e na proteção que o governo lhes dava contra os produtores externos. Nessa perspectiva, acordos com 
grupos externos para comercialização de produtos ou fornecimento de tecnologia constituíam uma distorção e deveriam ser evitados. Mas no final da década grande parte desse cenário já era passado. Isso é verdade ao menos para os grandes grupos privados nacionais, em sua maioria relacionado ao capital financeiro (Bradesco e Itaú). Tomando esses grupos, percebemos um movimento claro no sentido de um aprofundamento de seus laços comerciais e tecnológicos com as empresas estrangeiras, cujo indicador é o número crescente de acordos de cooperação em diversos segmentos da indústria de informática ${ }^{22}$. Com a consolidação desses relacionamentos comerciais, muitos atores nacionais passaram a questionar a proibição das joint ventures pelos órgãos governamentais e a exigir um maior grau de internacionalização para o setor.

Baseando seus planos comerciais nesses acordos de cooperação, os maiores fabricantes nacionais sob um certo aspecto abandonaram o modelo de desenvolvimento anteriormente formulado pelos nacionalistas, militares ou "guerrilheiros", em prol da modernização de seus produtos e tecnologia e aumento de competitividade. Conforme Evans, o sonho dos 'barbudinhos' (os técnicos nacionalistas) com a autonomia tecnológica era claramente negado nessa nova fase. No final da década de oitenta, os esforços tecnológicos locais eram dirigidos para tentar participar da economia global, e não mais atingir autonomia. (EVANS, 2004, p. 242).

Do outro lado, para as multinacionais atuantes no país fazia todo sentido realizar esses acordos com os grandes grupos nacionais, abandonando o ataque frontal à política realizado no início da década. Na medida em que essa estratégia se revelou ineficaz em diversos episódios, essas empresas compreenderam e sentiram a necessidade de utilizar abordagens mais flexíveis, que garantiriam a elas a participação no mercado nacional, ainda que não fosse no cenário idealmente desejado.

Essa alteração tem também outras causas, além da incapacidade de realizar o desmonte da política e convencimento dos burocratas brasileiros a baixar as restrições ao comércio. Um importante fator a ser destacado é o recrudescimento da concorrência internacional entre essas empresas. O Brasil constituía um importante mercado na área de

22 TAPIA (1995, p. 252) lista alguns desses acordos, firmados entre meados dos anos oitenta até 1991. Cito a associação IBM-Itautec para licenciamento de superminis (1989), a DEC-Elebra para distribuição de workstations (1989), e Fujitsu-Rima para licenciamento de impressora de tecnologia LED (1988). 
informática, e ficar de fora certamente representaria uma queda de receitas, em um momento em que o desenvolvimento tecnológico da indústria já estava levando a uma decrescente taxa de lucratividade, decorrente da comoditização dos equipamentos e perda de valor do hardware em relação ao software.

Essa nova atitude expressou-se na ampliação das modalidades de participação e de vínculos no mercado brasileiro. Assim, as empresas multinacionais buscaram uma aproximação com fabricantes nacionais de equipamentos em vários segmentos do complexo eletrônico, levando ao crescimento dos acordos de cooperação técnica e de aquisição de produtos para exportação. Passaram também a licenciar tecnologia em áreas protegidas pela reserva de mercado, estabeleceram associações em determinados segmentos, como o de serviços de informática, internalizaram a produção de certos produtos e procuraram laços com a comunidade científica, por meio de convênios com alguns dos principais laboratórios das universidades brasileiras. Esse novo comportamento das empresas multinacionais rendia dividendos políticos, ao legitimar sua presença no mercado brasileiro e ampliar o leque de interesses econômicos e políticos favoráveis a uma revisão da política.

Dessa forma, os acordos entre os grandes grupos nacionais e os fabricantes internacionais alteraram suas posições com relação à política de informática. $\mathrm{O}$ empresariado nacional passa a adotar uma postura de crítica, embora possivelmente seja um exagero dizer que pretendiam extinguir a proteção antes do prazo previsto para a lei. Ao contrário, a data limite de 1992 prevista na Lei 7.232/84 funcionava para essas empresas como um argumento de barganha contra seus parceiros internacionais.

Esses elementos, somados às críticas de economistas, parlamentares, empresários de outros setores e demais atores de importância política, e aos problemas inerentes à política e a seu momento de exaustão, sinalizam que já no final do governo Sarney estavam presentes a maioria dos elementos que levaram à reforma e substituição da política no governo seguinte. Tais fatores seriam obviamente agudizados nos meses que se seguem, mas considerando o quadro descrito parece bem claro que a trajetória da antiga política de informática estava naquele momento chegando ao seu fim. E outro reflexo disso é o fato de que já no governo Sarney se iniciaram as discussões para reformulação da política de informática. Tapia chega a afirmar que havia unanimidade entre governo, empresários 
nacionais (de informática e de outros setores), comunidade científica, usuários e partidos políticos quanto à necessidade de introduzir modificações no marco normativo previsto pela Lei 7.232/84. (TAPIA, 1995, p. 254).

Não havia, entretanto, acordo sobre o conteúdo dessas alterações. Duas propostas estavam em discussão naquele momento, que, considerando a divergência de modelos, idéias e medidas, revelam bem o dissenso entre os diversos atores sobre os rumos da indústria. A primeira foi elaborada no âmbito do BNDES, que depois de vários anos volta a apresentar interesse pelos rumos da política de informática, com uma proposta de viés liberalizante apresentada pelo seu Departamento de Estudos. O projeto expunha os principais problemas da indústria, com especial foco na falta de escala e competitividade, propondo a extinção do protecionismo indiscriminado e uma política com enfoque seletivo, que favorecesse as associações com empresas estrangeiras e concentração dos grupos locais, para com isso obter atualização tecnológica, economias de escala para redução de custos e possibilidade de participação no mercado internacional, ao mesmo tempo em que se permitiria ao capital externo acesso ao mercado nacional. (TAPIA, 1995, pp. 263-271).

A segunda proposta foi elaborada principalmente pelos quadros do MCT e da SEI, e correspondia a uma visão nacionalista de preservação das vitórias conquistadas pela política e sua reformulação no sentido de ganhar legitimidade política e enfrentar os novos desafios que se haviam apresentado. Um de seus principais objetivos era fortalecer uma SEI fragilizada por críticas do empresariado nacional e por problemas burocráticos internos. As diretrizes do plano contemplavam especialmente quatro eixos: o fortalecimento das empresas nacionais, a qualidade e normatização em informática, a redução de custos e preços, e as exportações. Em relação às empresas multinacionais, o plano estipulava que elas continuassem a ter um papel complementar. Inclusive, quanto às modalidades de obtenção de tecnologia, o plano menciona o licenciamento como a principal forma de resolução das dificuldades de atualização das empresas nacionais. Essa estratégia deveria ser seletiva e cuidadosa, evitando-se o uso de tecnologia estrangeira de maneira indiscriminada. Esse plano acabou servindo como base para o II Plano Nacional de Informática e Automação - II, aprovado em 1991 pelo Congresso Nacional, tendo sofrido no entanto algumas modificações para adequação às novas propostas do governo Collor. (TAPIA, 1995, pp. 271-275). 
Reitera-se, portanto, que já no final do governo Sarney, no fim dos anos oitenta, a antiga política de informática, tal como inicialmente concebida na Lei 7.232/84, já gozava de pouca sustentação política, e sua reforma ou extinção era vista como certa pelos principais grupos econômicos e políticos. Havia pouca ou nenhuma possibilidade de sua renovação nos mesmos moldes após o término de seu prazo inicial, que encerraria em 1992.

Restava apenas saber em que termos se daria a sua substituição, em especial qual das propostas acima mencionadas iria prevalecer no debate político. Considero que esse debate tem conseqüências mais profundas para o debate da política estruturada a partir da década de noventa, razão pela qual deixar este tema para o próximo capítulo. Passo assim à análise das alterações sofridas pela indústria de informática durante o período da antiga política, e quais os problemas e falhas desta em relação a seus objetivos, para afinal realizar um apanhado geral à luz do debate teórico com base no primeiro capítulo.

\section{$\underline{2.10 \text { Resultados e falhas }}$}

A fim de analisar como e em que medida a política de informática efetivamente afetou a indústria local é importante inicialmente retomar o que era a realidade do setor no Brasil no início da década de setenta, quando da criação da CAPRE e da instituição da reserva de mercado. Conforme mencionado, em 1970 o Brasil emergia como um grande mercado para a informática, em especial devido à industrialização em curso e à modernização da burocracia governamental. Era um típico cenário de país subdesenvolvido, com pouca ou nenhuma tecnologia local, sendo as tentativas de pesquisa e desenvolvimento para inovação ainda muito recentes e tímidas, sem qualquer resultado comercial expressivo.

Governos anteriores haviam conseguido trazer multinacionais do setor para produzir e comercializar localmente seus produtos, que inclusive colaboravam para a exportação de manufaturados (a IBM e a Burroughs, por exemplo). Outras medidas, como a criação de um regime especial de importação de produtos em Manaus no final da década de sessenta, favoreceu a entrada de produtos estrangeiros. Esses fatos se deram em um momento embrionário da indústria, quando alguns poucos grupos internacionais (em especial a IBM) tinham virtualmente um monopólio mundial no setor. 
A realidade, portanto, da informática brasileira era um grande mercado em expansão, que via sua demanda suprida por grupos internacionais que possuíam o domínio de ponta dessa tecnologia, e que produziam numa escala mundial que lhes proporcionava uma enorme competitividade em suas fabricações e pesquisas. A importância de levantar esses fatos é indagar quais eram de fato as chances de grupos empresariais nacionais se interessarem no setor de informática de forma 'espontânea', ou de formação de capacitação e recursos humanos no setor, sem que houvesse uma maciça intervenção de política pública nesse sentido. A resposta parece ser que eram muito poucas. Nenhum caminho natural levava os grupos industriais sofisticados a substituir os setores já conhecidos pela informática. Conforme Evans, "as políticas anteriores ajudaram a destruir qualquer caminho que pudesse ter existido para a eletrônica de consumo e implantou severas restrições à entrada no mercado de informática local". (EVANS, 2004, p. 209). É realmente muito difícil imaginar que sem a intervenção de uma política setorial focada naquele momento surgisse uma diversidade de empresas de capital interno dispostas a competir, ainda que apenas no âmbito local, nesta área na qual o país não tinha qualquer tradição ou maiores recursos. Basta lembrar a dificuldade do governo para encontrar um parceiro nacional no projeto que resultou na COBRA, e que a maioria dos engenheiros formados no ITA à época que ficavam no país acabavam se tornando vendedores da IBM e outras empresas, por falta absoluta de empresas e programas de pesquisa para desenvolvimento local de produtos.

Tendo em vista esse cenário inicial, é razoável atribuir, no mínimo em parte, à política de informática alguns dos desenvolvimentos do setor ocorridos nos anos que se seguem, até o final da década de oitenta. Especialmente no tocante a hardware e equipamentos no segmento inferior (minis, superminis e microcomputadores), dezenas de firmas produtoras foram criadas após a concorrência dos minicomputadores em 1977. A reserva de mercado ofereceu às firmas brasileiras a oportunidade de explorar uma mudança tecnológica e competir no mercado interno.

A proteção garantia às nascentes empresas nacionais não apenas que elas não teriam que competir com os grandes atores globais, como também assegurava uma demanda por produtos e serviços, algumas vezes com especificidades e aplicativos próprios a serem desenvolvidos. Essa demanda possibilitou não só o parto inicial dessas empresas como também o seu forte crescimento durante os seus primeiros anos. A 
indústria brasileira de informática destacou-se ao longo da década de oitenta pelo desempenho bastante acima do conjunto da indústria, com uma média anual de crescimento de $22,7 \%$, com expressivo incremento seja em termos de volume de negócios como na oferta de produtos. (TAPIA, 1995, p. 239). Dentro dessa média as empresas nacionais se destacaram ainda mais, o que permitiu que elas elevassem sua participação no faturamento total da indústria de apenas $23 \%$ para 59\% em apenas dez anos (1979-1989). (EVANS, 2004, p. 213). E esse crescimento da produção doméstica verificou-se a partir de níveis crescentes de índices de nacionalização, implicando não só a sustentação de patamares relativamente baixos de importações como também a formação de um amplo espectro de fornecedores especializados por parte, inclusive, das empresas estrangeiras instaladas no país. (BAPTISTA, 1997)

Outro dado expressivo, e possivelmente ainda mais importante, é o número de profissionais com formação técnica empregados na indústria. Mais de vinte mil desses novos empregos foram criados até 1989, sendo as empresas nacionais responsáveis por aproximadamente três quartos desse total. Isso revela a formação de material humano qualificado para o setor, decorrente da criação dos cursos de engenharia eletrônica e outros para atender à demanda das empresas criadas.

Quanto aos dispêndios em pesquisa e desenvolvimento, um dos principais objetivos da política, as empresas brasileiras também revelaram um forte empenho e capacidade inovadora. Ao longo deste período, observou-se uma elevação persistente nos níveis desses dispêndios (uma média de $10 \%$ do faturamento bruto). Estes gastos converteram-se em ganhos significativos de aprendizado tecnológico e na formação de um expressivo contingente de recursos humanos especializados.

As estratégias tecnológicas das empresas misturavam práticas como o licenciamento de tecnologia externa, engenharia reversa e desenvolvimento próprio. Quanto aos resultados, a indústria nacional conseguiu se expandir em alguns segmentos importantes do mercado. Além disso, observou-se a redução do espaço temporal de introdução de novas gerações de produtos no mercado brasileiro, relativamente à sua data de lançamento mundial. (BAPTISTA, 1997). 
É interessante constatar que o crescimento das firmas nacionais não se deu em detrimento (ao menos não completamente) do desenvolvimento das multinacionais atuantes no país. Esses grupos continuaram crescendo no país a altas taxas, lembrando que no segmento superior de mercado (mainframes e grandes máquinas) as multinacionais detinham controle completo da produção.

Por fim, um dos grandes avanços da indústria nesse período foi no setor de automação bancária. Desde a década de setenta, com a cooperação que se iniciou com a COBRA, o capital financeiro se interessou pela crescente área de informática, e fez parte de sua história. Na verdade era um setor que percebeu o quanto tinha a ganhar com a automação de procedimentos, e, com a reserva de mercado, percebeu que precisaria entrar nesse jogo para ver sua demanda atendida. Assim, a influência do setor bancário para o crescimento da indústria de informática foi decisiva, ao menos por dois aspectos. Em primeiro lugar por aportar um grande volume de capital. Se a política de informática pode ser criticada por não gerar empresas com tamanho e escala internacional, ao menos grande parte dos grupos nacionais de maior porte estavam ligados ao capital bancário (por exemplo o Banco Itaú detinha a Itautec e Itaucom, e o Bradesco possuía participações na Sistemas de Informação Distribuída - SID, uma subsidiária integral chamada Digilab e posteriormente entrou como principal investidor da Elebra - EVANS, 2004, p. 214). Além disso, esse foi um setor no qual a relação produtor-cliente se mostrou especialmente profícua e vantajosa. Os grupos financeiros demandavam equipamentos e soluções para a automação de seus procedimentos, gerando constante demanda não só para os produtos fabricados como também para novas inovações, fomentando a assim a pesquisa dos grupos empresariais de computação.

Tendo considerado os aspectos positivos da política, é importante também delinear suas falhas, que já foram objeto de diversas discussões e trabalhos, até mesmo porque, conforme mencionado, essas questões foram relevantes para a fragilidade das diretivas governamentais no início dos anos noventa. As principais críticas costumam atribuir à política protecionista os problemas que os usuários levantavam durante esse período. Preços elevados, atraso tecnológico e problemas de qualidade em comparação com os produtos vendidos no mercado internacional eram algumas das reclamações comuns. 
Políticas de proteção industrial contra concorrência externa como a antiga política de informática possuem uma contradição de difícil solução, expressa pelo dilema entre competitividade e capacidade tecnológica. Na medida em que cria uma estufa que permite o crescimento das empresas locais, também traz a oportunidade para que os agentes privados se acomodem e não busquem a melhoria de seus produtos ou de sua competitividade (ou simplesmente acumulem rendas). Ou esses agentes podem simplesmente adotar estratégias de fabricação baseadas em réplicas ou clones de produtos tecnologicamente ultrapassados no mercado externo. Assim, a política gerava um grande incentivo para os empresários locais não inovarem ou não se preocuparem com sua competitividade.

Os problemas não se resumem a essa contradição. A questão do preço, por exemplo, apresentava outros componentes, como a falta de seletividade da política. Não estabelecendo um foco mais apurado em alguns setores ou componentes específicos a política acabava fazendo com que os produtores despendessem inutilmente esforços em diversas áreas, muitas das quais as empresas brasileiras não tinham condições de competitividade, o que diminuía sua eficiência e capacidade de especialização, além de aumentar excessivamente os custos.

Para Baptista, a questão do preço é chave para a compreensão do fracasso da política de informática, e resultou da conjugação de quatro fatores fundamentais:

\footnotetext{
“(i) da obrigatoriedade de aquisição no mercado interno de várias famílias de componentes a preços substancialmente superiores aqueles praticados no mercado internacional; (ii) da verticalização excessiva das empresas; (iii) do negligenciamento observado, nas estratégias empresariais, à tecnologia de processos e à otimização e racionalização da produção; (iv) da possibilidade de sustentação de altas margens de lucro, dada a proteção frente às importações de que desfrutavam as empresas locais (nacionais e estrangeiras)." (BAPTISTA, 1997).
}

Outros grandes problemas enfrentados pelas empresas nacionais eram o pequeno tamanho do mercado interno (que apesar de promissor era insuficiente para gerar maiores economias de escala) e a pulverização excessiva das empresas. Se é verdade que havia concorrência no mercado brasileiro, também é que esse mercado equivalia a apenas $1 \%$ do mercado norte-americano. (EVANS, 2004, p. 212). Com esse tamanho as empresas locais dificilmente conseguiriam se aproveitar de economias de escala para atingir níveis 
internacionais de competitividade. Ainda que os grupos financeiros tenham aportado grandes volumes de investimento na indústria de informática, nem esse capital nem o governo foram capazes de gerar uma empresa com tamanho, volume de negócios e recursos para pesquisa capaz de competir internacionalmente fora do cenário da reserva. Isso é bem nítido se considerarmos o desempenho das exportações brasileiras, que foi bastante modesto no período. As empresas de capital nacional pouco participavam desse mercado (mais de 90\% das exportações eram de responsabilidade de empresas de capital externo), e as exportações correspondiam a apenas $4 \%$ do faturamento total da indústria, caindo para menos de $1 \%$ se considerarmos apenas os grupos de capital local. (TAPIA, 1995, p. 241). Percebe-se dessa forma que as empresas locais possuíam pouca vocação e competitividade para atuar no mercado internacional, dependendo sua existência do mercado interno cativo gerado pela proteção estatal.

Há diversas outras críticas que foram levantadas contra a política de informática nos anos oitenta. Algumas delas referem-se à falta de recursos financeiros mais expressivos por parte do governo, o que teria limitado o crescimento e concorrência interna entre as empresas e a ausência de metas de desempenho claras, que poderia ter solucionado o problema da racionalidade oportunista e não inovadora gerada pela política conforme mencionado acima. Um outro ponto que considero especialmente relevante é a falta de articulação da política de informática com um planejamento estatal ou uma estratégia de desenvolvimento mais abrangente. A informática e computação pode interagir diretamente com outros setores da economia, e da mesma forma uma política integrada que levasse em consideração os esforços estatais em outros campos poderia ter beneficiado a indústria a cumprir melhor seu papel e levado a uma maior informatização da sociedade, o que certamente reverteria em maiores benefícios e novas demandas para os produtores locais.

Em defesa da política, entretanto, devo destacar que este foi o momento em que a política de informática esteve mais próxima dos objetivos centrais do governo federal brasileiro. A SEI era um órgão ligado diretamente à cúpula do governo (SNI e CSN), e a centralização da política em suas mãos solucionou uma série de conflitos políticos e questionamentos que eram levantados no período anterior. A articulação e efetivação da política, assim, estava em grande parte garantida pelo prestígio dos órgãos responsáveis por sua formulação e implementação. 
Tomando todos os dados e análises mencionadas, acredito que uma conclusão plausível é que algo ocorreu nas décadas de setenta e oitenta, e isso mudou radicalmente o rumo no qual a indústria de informática se encontrava no início desse período. E parece razoável atribuir ao menos em parte à política de informática a responsabilidade por essas mudanças. Foi uma política que apresentou problemas diversos e falhas, mas não se pode negar que ocorreu uma mudança fundamental nesses anos. A informática estava no mapa empresarial do Brasil. Uma fração proeminente da classe empresarial local investiu significativamente na indústria. Conforme coloca Evans, o papel de "Estado parteiro" fora bem-sucedido. (EVANS, 2004, p. 216). Existem obviamente outros componentes, sendo um de grande relevância a mudança tecnológica e a janela de oportunidade que surgiu com os microprocessadores. Mas esses fatores indicam que a política foi desenvolvida em um momento crucial do desenvolvimento tecnológico do setor no qual as chances de inserção ainda se encontravam presentes, revelando assim uma extraordinária capacidade de análise e decisão dos policy-makers brasileiros (em especial dos técnicos frustrados e nacionalismo militar).

A abertura que se daria nos anos seguintes, com a entrada do governo Collor, alteraria radicalmente grande parte desse cenário. Entretanto, não considero adequado atribuir o desmonte ocorrido das capacidades construídas no período apenas aos problemas intrínsecos identificados. Analisando a antiga política sob a perspectiva atual, anos após o seu término, o primeiro impulso é obviamente reconhecer que, devido às falhas da política e às limitações dos grupos empresariais, grande parte desses agentes privados não seria mesmo capaz de sobreviver à concorrência externa, ou teria que realizar uma série de fusões e se especializar em nichos específicos de mercado.

Todavia, tomando em conta as circunstâncias e o quadro da indústria naquele momento, me parece mais correto pensar que o jogo ainda estava aberto, e que seriam as próximas decisões políticas e econômicas do governo e das empresas que iriam determinar os próximos passosa. A forma e em que termos seria extinta a reserva de mercado e se realizaria a abertura econômica tiveram papel crucial aqui, assim como os incentivos escolhidos para preservação da capacidade tecnológica obtida e como estimular a competitividade dos grupos locais. Tudo isso parece ser também de fundamental para compreensão do que houve com a informática brasileira dos anos noventa, sendo o tema do próximo capítulo. 


\subsection{Análise teórica da política}

A política de informática brasileira pré-anos noventa é definitivamente um exemplo de política oposta a uma visão liberal (neoclássica) de aproveitamento de vantagens comparativas. A criação de "estufas" de proteção à indústria tem objetivo claro de geração de capacidades tecnológicas e incentivo à competitividade ao longo do tempo.

$\mathrm{Na}$ década de setenta não era clara qual estratégia seria adequada para lidar com a informática. O setor vivia então o seu primeiro grande surto de dinamismo e revolução tecnológica, em especial nos países desenvolvidos. A informática começava a ser utilizada pelos demais setores econômicos com grande aumento de produtividade, e havia uma grande demanda por novas tecnologias que pudessem ampliar a capacidade de processamento e funcionalidade das máquinas. A velocidade e dinâmica das mudanças tecnológicas nesse setor, conjugadas com sua complexidade e grande volume de componentes e insumos intensivos em conhecimento, tornavam muito pouco claro qual deveria ser o papel do Estado no desenvolvimento dessa indústria, e se a burocracia governamental teria a capacidade e competência técnica para cumprir com essa tarefa. A resposta imediata para essas perguntas, conforme Evans, acabava sendo a reafirmação da fórmula neoliberal: o governo não tem agilidade ou conhecimento técnico necessário para intervir positivamente. (EVANS, 2004, p. 135).

Alguns países de industrialização recente como o Brasil, no entanto, não aceitaram essa lógica. Havia uma clara noção de que, sem o Estado, o empresariado nacional pouco poderia fazer para implantar uma indústria de informática, devido à ausência de capital, recursos humanos e tecnologia necessária. Aceitar as versões tradicionais da teoria das vantagens comparativas iria deixar esses países à margem do processo tecnológico em andamento. Além disso, o exemplo que vinha dos países industrializados não era exatamente um modelo de absenteísmo estatal, haja vista a existência de projetos ambiciosos de informática com financiamento ou participação do governo no Japão e nos Estados Unidos. (EVANS, 2004, p. 136).

O interessante sobre a antiga política de informática é que, analisando-a sob o prisma teórico do debate sobre política industrial, ela fornece elementos de sustentação para ambos os modelos apresentados. Por um lado, a atuação governamental pode ser 
considerada decisiva para a construção do parque industrial e dos recursos humanos capacitados tecnologicamente para lidar com o setor. Mas, em sentido contrário, foi também gerador de rendas e ineficiências econômicas, protegendo empresas sem condições de competitividade e aumentando os preços para o consumidor final.

É importante ressaltar que a idéia de estufas de proteção industrial está muito mais ligada às obras de Friederich List do que propriamente aos autores neoschumpeterianos. Embora ambas as correntes possam ser consideradas exemplos de atuação estatal mais intensiva e política industrial abrangente e seletiva, a escola neoschumpeteriana não faz uma defesa expressa do protecionismo industrial contra a concorrência externa.

A tese da indústria nascente, em brevíssimas linhas, argumenta que, em face dos países desenvolvidos, os mais atrasados não conseguem desenvolver novas indústrias sem a intervenção do Estado, principalmente por meio de tarifas protecionistas. O livre comércio, assim, seria benéfico apenas entre países de nível semelhante de desenvolvimento industrial, mas não entre os que têm diferentes níveis de desenvolvimento. List argumentou que a Grã-Bretanha e os Estados Unidos são grandes exemplos de nações que protegeram sua indústria na fase inicial e depois de concluída a industrialização passaram a negar essa estratégia, advogando o livre comércio ${ }^{23}$.

Os evolucionários neoschumpeterianos dão uma maior ênfase à competitividade dinâmica das empresas. Dessa forma, a concorrência externa não é vista necessariamente como um malefício. Ao contrário, as políticas governamentais devem sempre se pautar no sentido de conferir às empresas a oportunidade e capacidade de competir nesse cenário, buscando eficiência e inovação tecnológica ao longo do tempo.

Assim, tomando a história e o conjunto de medidas adotadas durante a antiga política de informática, não se pode afirmar que ela estivesse totalmente de acordo com os preceitos dos autores evolucionários, aproximando-se mais dos argumentos de List. Encontra, no entanto, seu ponto de convergência com essas duas doutrinas na medida em que tinha como objetivo básico gerar capacidade tecnológica local, através do fomento da pesquisa e da formação de quadros técnicos para o setor, e gerando demanda para a

\footnotetext{
${ }^{23}$ A esse respeito ver CHANG, 2004.
} 
produção de tecnologia local. Na perspectiva evolucionária, os métodos utilizados podem ser criticados por abandonar a questão da competitividade das empresas e da inserção internacional ativa, mas de certa maneira os objetivos finais se encontram fortemente relacionados com os propostos por seus autores.

Conforme mencionado, algumas das críticas levantadas contra a política eram o problema dos preços elevados e das exportações irrisórias, o quadro institucional que favorecia o oportunismo e inibia esforços de inovação mais expressivos, e a falta de metas de desempenho. Essas falhas revelam um desacordo com um dos principais pontos da teoria neoschumpeteriana, que é a sobrevivência das empresas no longo prazo, baseada em sua capacidade inovativa e no conjunto de habilidades (skills) adquiridas ao longo de sua trajetória.

À parte desses problemas, entendo que a antiga política apresenta elementos que sustentam e corroboram algumas das teses evolucionárias. A principal, em especial sob a perspectiva do direito, é que o Estado, o conjunto de instituições e o arcabouço normativo certamente desempenharam um fator decisivo na evolução econômica e tecnológica desse setor durante o período. Conforme tentei esboçar, dificilmente se poderia afirmar que o rumo da informática brasileira no início dos anos setenta apontasse para a constituição de dezenas de empresas locais produzindo mini e microcomputadores e atendendo à demanda de automação bancária. Esse argumento, se não é capaz de demonstrar definitivamente, pesa muito a favor de que a política industrial de abordagem não restrita adotada teve muito a ver com os rumos tomados pela indústria. Assim, acredito que em favor da corrente evolucionária, a antiga política de informática traz excelentes argumentos para afirmar que política industrial pode sim induzir à industrialização e capacitação tecnológica em um determinado setor, se planejada e conduzida tendo em vista elementos como o momento tecnológico no qual o setor se encontra.

Não pretendo com isso afirmar que este foi o único fator responsável, muito menos defender que se trata de um molde a ser seguido em todo caso em que se pretenda constituir capacitação em um dado setor econômico. Elementos históricos, tecnológicos e a herança institucional brasileira foram também de grande relevância. Conforme já foi dito, possivelmente pouco poderia ter sido construído sem a "janela de oportunidade" aberta com o surgimento dos mini e microcomputadores. 
Cumpre, por sinal, dizer resumidamente do que se trata uma janela de oportunidade (window of opportunity). O conceito é bem explicado e faz parte da modelagem teórica elaborada por Perez e Soete (1988). Os autores partem das idéias de trajetória natural ou trajetória tecnológica (expostas, respectivamente, por Nelson e Winter, e Dosi), segundo a qual todo novo produto ou inovação colocada no mercado possui um ciclo, que passa por quatro fases: introdução, crescimento inicial (early growth), crescimento tardio (late growth) e maturidade. Cada uma dessas fases possui características próprias, sendo especialmente relevantes os custos para os novos entrantes. Segundo os autores, as fases que apresentam as melhores oportunidades ou menores custos de entrada seriam a de introdução, por requerer pouco capital e experiência, e maturidade, na qual o produto se encontra comoditizado e sua produção depende de vantagens comparativas tradicionais (baixo custo), embora o investimento inicial seja alto.

A fase inicial de introdução, apesar de apresentar maiores riscos, constitui uma janela de oportunidade para novos entrantes no mercado. A sua grande condição traduz-se principalmente na disponibilidade de conhecimento científico e técnico apropriado e recursos humanos capacitados. Conforme os autores, “[...] dada a disponibilidade de pessoal universitário bem qualificado, uma janela de oportunidade se abre para a entrada relativamente autônoma [no mercado] de novos produtos em um novo sistema tecnológico em suas fases iniciais." (PEREZ E SOETE, 1988, p. 476, tradução nossa, grifos nossos) ${ }^{24}$. O momento inicial do ciclo de um produto ou tecnologia em sua trajetória constitui, portanto, a melhor circunstância ou oportunidade na qual um país ou região pode realizar o catching up tecnológico. Isto obviamente não é automático. Se não ocorrer um esforço anterior de absorção e construção de conhecimento científico e disseminação através de um grupo preparado para o desafio, não haverá maiores possibilidades de aproveitamento da oportunidade.

À luz dessa teoria o momento específico no qual se desenvolveu a antiga política de informática parece ter sido ainda mais propício. A introdução da tecnologia dos microprocessadores parecia certamente constituir uma janela de oportunidade para o país, e

\footnotetext{
24 "this implies that, given the availability of well-qualified university personnel, a window of opportunity opens for relatively autonomous entry into new products in a new technology system in its early phases". (PEREZ E SOETE, 1988, p. 476).
} 
os técnicos nacionalistas frustrados estavam dispostos a apostar nessa idéia. O país tinha capacidade técnica e pessoal especializado disposto a tomar este desafio, e uma burocracia que tinha obtido poder administrativo para realizar uma política devido às crises econômicas internacionais.

Já sob o prisma da teoria neoclássica e dos autores que defendem uma política industrial restrita a antiga política de informática também concede dados expressivos que corroboram seus argumentos. Esses argumentos e fatos foram citados e mencionados à exaustão pelos opositores da política, inclusive nos anos seguintes a sua extinção. $\mathrm{O}$ desmonte da grande maioria das empresas de informática nesse período, por exemplo, pode ser lido sob esse viés teórico como uma prova de que esses atores adotaram estratégias de rent-seeking, e abandonaram suas empreitadas quando cessou a intervenção governamental que lhes garantia o lucro.

A baixa qualidade e tecnologia dos produtos se comparado ao mercado internacional, aliados a seus altos preços, também é lido como evidência da falta de competitividade das empresas brasileiras. Assim, a abordagem neoclássica consideraria uma ineficiência alocativa a proteção ou incentivo estatal a essas empresas, pois não havia aqui qualquer falha de mercado a ser corrigida. A intervenção governamental teria retirado a economia de seu curso ótimo ou sub-ótimo, afastando-a (ainda mais) de um ideal de otimalidade paretiana. Tais investimentos poderiam ter sido dirigidos para setores nos quais a economia brasileira fosse naturalmente mais competitiva, aumentando assim os rendimentos do agregado econômico. Mais grave ainda, a proteção a um setor considerado não plenamente competitivo teria afetado as demais áreas da economia, que foram obrigadas a utilizar produtos mais caros e menos desenvolvidos do que aqueles utilizados no mercado internacional, afetando também seu poder de competir no âmbito interno e externo. Esse aspecto foi muito ressaltado pelos opositores da política de informática, em especial os outros ramos do capital industrial nacional, que se consideravam sofrendo pelas ações do governo brasileiro.

As teorias de falhas de governo encontram guarida em alguns dos problemas enfrentados pela política. A questão do rent-seeking, conforme mencionado, e também o problema de informação dos agentes públicos estão presentes nesta discussão. Parte da implementação e do sucesso da política se deveu a fatores externos e não propriamente 
programados pelos burocratas da CAPRE e da SEI, como a crise do petróleo e a introdução dos microprocessadores. Mas outros aspectos vieram em seu prejuízo, como a ascensão da ideologia ortodoxa econômica no final da década de oitenta e a crise da dívida brasileira, e isso revela uma incapacidade (natural) dos agentes governamentais de conseguir se antecipar a essas novas tendências e problemas, tomando medidas para os neutralizar ou minimizar.

Acredito que este diálogo da pesquisa exposta neste capítulo com o debate teórico da parte anterior revela-se muito importante em uma análise jurídica. As escolas de pensamento descritas no primeiro capítulo me ajudam a explicar com maior propriedade e embasamento teórico a forma através da qual o Estado e o direito (o arcabouço normativo) influenciaram positiva ou negativamente a política pública e este primeiro momento de construção do setor de informática (este exercício será realizado na parte final desta dissertação - ver as Conclusões e Lições do Estudo). Seus argumentos e prescrições sobre a intervenção do Estado na economia possuem forte importância e caráter explicativo, motivo pelo qual entendo que não podem ser desconsiderados em uma análise jurídica ou normativa. Um estudo que prescinda deste diálogo seria, a meu ver, incompleto, na medida em que o método tradicional utilizado na ciência jurídica usualmente se limita ao exame abstrato do ordenamento, negligenciando os elementos importantes na construção da norma, e suas conseqüências e decorrências fáticas. E uma tal análise parece abertamente inapropriada quando o tema em questão é uma política pública, que, no conceito adotado, só manifesta sua relevância e razão de ser no problema que levou a sua formulação e resultados efetivamente atingidos.

Volto, por fim, à afirmação que fiz no início deste capítulo, de que a antiga política de informática brasileira é um dos momentos mais ricos e interessantes para o estudioso de políticas públicas. Ela dialoga com ferramentais teóricos de diversas ordens, e apresenta fatos diversos para reforçar ou refutar alguns dos argumentos levantados. É por essa razão, por sinal, que diversos autores já se dedicaram a olhar para este período da informática nacional, com diferentes hipóteses e metodologias, ressaltando fatos e levantando questões que interessavam sob seu ponto de vista.

Sob a perspectiva que se apresenta para este trabalho, considero que as informações levantadas até aqui são suficientes para sua utilização como ponto de partida e pano de 
fundo para o momento seguinte da política brasileira, iniciado com o governo Collor de Mello e sua PICE na década de noventa. 


\section{CAPÍTULO 3. A ABERTURA ECONÔMICA E A NOVA POLÍTICA DE INFORMÁTICA}

Após anos de proteção estatal e da tentativa de construção deliberada de uma indústria de informática inovadora e tecnologicamente avançada, os anos noventa chegam ao país com a predominância da perspectiva econômica liberal, reforçada pelas recomendações políticas de Williamson e o Consenso de Washington ${ }^{1}$. A antiga política de informática representava uma das maiores antíteses a esse pensamento, tornando-se um alvo natural de suas críticas. Uma nova política foi a partir de então sendo formulada, uma política que, programada para atingir seu prazo final em sete anos, já conta atualmente com uma década e meia de existência, tendo previsão de duração de ao menos mais uma.

Vou argumentar que um importante elemento de sustentação da nova política de informática que lhe garantiu a sobrevivência por tanto tempo foi certamente superar o embate ideológico da década de oitenta, abrindo caminho para uma decisão conciliatória que lhe resguardou de grandes críticas, ao menos no plano teórico. A política de informática na década de noventa acabou por encontrar seu maior conflito com uma outra política pública desenvolvida pelo governo federal - a ZFM.

Neste capítulo será feita a reconstrução histórica e análise da política de informática a partir da década de noventa, que constitui o objeto central de estudo desta dissertação. As questões que pretendo responder se referem aos resultados da política e suas relações com o debate teórico formulado no primeiro capítulo, bem como aos problemas e falhas relacionadas ao seu processo de implementação. As hipóteses de trabalho tomadas como premissas são: (i) o processo de formulação e implementação da política de informática permite identificar nela elementos teóricos de cunho liberal e neoschumpeteriano, sendo equivocada a idéia de que se trata de mera renúncia fiscal sem outros objetivos e resultados significativos; (ii) a abertura de mercado e as medidas liberalizantes tomadas especialmente pelo governo Collor de Mello, ao incitar a concorrência e permitir a entrada de novos agentes com maior escala e capacidade tecnológicas, tiveram repercussões vantajosas tanto nos preços quanto em aspectos qualitativos dos equipamentos disponíveis no país, nos termos descritos pelo referencial teórico neoclássico; (iii) a política, e em

\footnotetext{
${ }^{1}$ Ver capítulo anterior.
} 
última análise o Estado e o direito, também tiveram papel importante na reconfiguração da estrutura produtiva do setor e das atividades das empresas nesse período, e instrumentos normativos de incentivo à competitividade de viés neoschumpeteriano foram capazes de, ao menos em parte, alterar a racionalidade do empresariado, atingindo alguns dos objetivos pretendidos; (iv) ainda assim, algumas questões de central relevância, como o enorme déficit setorial na balança comercial brasileira e a quase inexistência de uma indústria de componentes, não foram solucionadas, em parte porque não eram de fato problemas que poderiam ser atacados por esta política; (v) parte dos temas surgidos ao longo dessa década podem ser atribuídos a falhas internas da política, bem como de seu processo de formulação e implementação.

A primeira parte deste capítulo fornece uma rápida idéia sobre o ambiente político brasileiro no início da década de noventa, permitindo uma contextualização que irá ajudar a compreender este momento crucial na formulação da nova política. Da segunda a sétima parte realizo a narrativa dos principais fatos e eventos que marcaram a política de informática, desde a discussão da primeira versão da lei até sua última renovação em 2004, com a já mencionada ênfase aos aspectos jurídicos e correlatos desse processo. A oitava parte expõe o momento vivido pela indústria de informática no âmbito global durante o período abordado, e questiona os efeitos e repercussões da abertura de mercado para o setor brasileiro. O objetivo é uma tentativa (ainda que artificial) de separar questões econômicas derivadas desses eventos ou processos dos resultados específicos da política de informática, o que é feito na parte nona. Por fim, na décima e última parte do capítulo exponho algumas conclusões retomando os temas centrais sobre a política, retornando ao debate teórico que embasa as análises dessa dissertação.

\subsection{O Governo Collor de Mello e a nova orientação econômica}

O primeiro governo nacional eleito após o fim do período da ditadura subiu ao poder em março de 1990, com desafios e tarefas de grande magnitude. O cenário hiperinflacionário e a crise fiscal e financeira do Estado brasileiro atingiam proporções insustentáveis. Devido a essa crise e aos problemas políticos enfrentados, os momentos finais do governo anterior foram caracterizados por um forte imobilismo. Qualquer nova estratégia de política a ser implantada pelo novo governante passava necessariamente pelo rompimento dessa inércia e enfrentamento dos problemas. 
Desde as eleições ocorridas em novembro e dezembro do ano anterior, o então candidato e seu Partido da Reconstrução Nacional - PRN já apresentavam um forte discurso de liberalização da economia. Essa postura trouxe receio na indústria de informática local, temerosa de perder a proteção da política dos governos anteriores. Isso fez com que os empresários do setor apoiassem abertamente o candidato adversário (Luís Inácio Lula da Silva). Quando viram suas pretensões frustradas com a eleição de Collor de Mello, passaram a concentrar suas forças no Congresso Nacional, pressionando os parlamentares para apoio de suas bandeiras. Até a posse do novo governo, no entanto, o discurso ainda era cauteloso, embora a mensagem de liberalização fosse bem firme. Falava-se em "acordo equilibrado entre os interesses dos produtores, usuários e governos", e na manutenção da SEI como órgão decisório, promessa que não resistiu ao primeiro ano de governo ${ }^{2}$.

Com a posse se encerrou o tom ameno. O Plano Brasil Novo, famoso pelo nome de Plano Collor, é lançado um dia depois da posse - um plano de estabilização violento, baseado na captura das poupanças privadas e no lançamento de uma nova moeda (o cruzeiro). Esse primeiro plano foi seguido pelo Plano Eris de controle monetário (maiodezembro), e ainda pelo Plano Collor II, no começo de 1991. Todos sem maiores sucessos: no final de 1991, a inflação mensal no Brasil ainda estava na casa dos 20\%. (BRESSER PEREIRA, 2003, p. 274). As medidas tiveram forte impacto sobre a indústria de computação. Não bastando os anúncios e ameaças de que a reserva de mercado estava com os dias contados, essas empresas tiveram ainda que enfrentar sérias perdas decorrentes dos planos de estabilização ainda no primeiro semestre de 1990.

No campo comercial, o novo governo revelou abertamente seu programa de liberalização econômica com o lançamento de uma nova política industrial. A Portaria 365/90 do Ministério da Economia, Fazenda e Planejamento - MEFP publica as Diretrizes para a Política Industrial e de Comércio Exterior - PICE, assinadas pela então ministra Zélia Maria Cardoso de Mello. A PICE estabelece a utilização de formas de ação governamental "substancialmente diferentes daquelas vigentes ao longo do processo de substituição de importações", tendo por objetivo o aumento da eficiência na produção e comercialização de bens e serviços. Este documento será a base e irá nortear as reformas

\footnotetext{
${ }^{2}$ Conforme reportagem: NOVAS cores na Informática. Dados e Idéias. Janeiro de 1990, pp. 18-21.
} 
na política econômica em diversos âmbitos, como o caso da indústria de informática. Conforme Baptista, a PICE traça um "diagnóstico da natureza estrutural da crise brasileira", partindo do esgotamento de uma estratégia desenvolvimentista corrente no país desde os anos 50, calcada na proteção ao mercado interno e substituição de importações. (BAPTISTA, 1997).

Nesse novo Estado pós-desenvolvimentista, modelo preconizado na PICE, a atuação passaria a ser menos intrusiva, deixando de proteger setores econômicos nacionais e restringir a entrada e circulação de capital e produtos externos, para adotar uma postura mais neutra, deixando ao mercado e aos agentes econômicos a decisão dos setores a serem investidos. A principal responsabilidade do Estado deveria ser a garantia da estabilização macroeconômica e a construção de um ambiente favorável aos investimentos em geral, com o estabelecimento de regras claras e estáveis para a vida econômica. O capital estrangeiro é considerado não só desejável como também uma peça chave do modelo. A atração deste capital se daria pela estabilização econômica e retomada do crescimento em bases internacionalmente integradas. $\mathrm{O}$ capital estrangeiro trazido para a produção interna permitiria o aumento da taxa de investimento local, a agilização e incremento do mercado externo, e a modernização tecnológica. A PICE representa, assim, uma nova postura frente ao capital externo, reforçada pela eliminação de "restrições setoriais anacrônicas e de preconceitos residuais".

Para o governo, a PICE era um segundo passo de sua política estabilizadora. Após as radicais medidas adotadas com o Plano Collor e subseqüentes, seria necessário um novo conjunto de medidas, que garantissem a modernização e competitividade externa do setor industrial, embasando assim um novo ciclo sustentável de crescimento da economia (conforme a PICE: “A implementação de uma Política Industrial e de Comércio Exterior componente central da retomada do desenvolvimento em novas bases - é, por conseqüência, elemento indispensável para consolidar e dar sentido de continuidade ao processo de estabilização em curso" - Portaria MEFP 365/90).

A ação do governo pautar-se-ia pelos pontos acima. A PICE estabelecia como seus principais objetivos a modernização industrial e comercial, consubstanciada pelo aumento da produtividade e por padrões internacionais de qualidade, a serem alcançados com base em crescente capacitação tecnológica, e a implementação de modernas estruturas de 
produção e consumo de bens e serviços em todo o espaço econômico nacional, pela difusão de novos padrões tecnológicos.

Os instrumentos de política previstos abrangiam medidas voltadas à liberalização e abertura do mercado brasileiro, e também outras de fomento à pesquisa e competitividade das indústrias locais, como o financiamento da capacitação tecnológica. Há uma forte ênfase na política de importações. O governo comemorava haver extinto as restrições à importação de mais de mil produtos, afirmando que a tarifa aduaneira passaria a ser o único instrumento de política adotado nesse campo. Outros pontos relevantes são o apoio à capacitação tecnológica da indústria e o uso do poder de compra do governo para geração de demanda a setores tecnológicos de ponta.

Com base nessa descrição, pode-se auferir que, conforme Baptista (1997), a PICE sustentava-se em quatro pilares básicos: abertura comercial (consubstanciada na redução tarifária e na remoção das restrições não tarifárias), desregulamentação dos mercados, eliminação das restrições ao capital estrangeiro e privatizações.

Alguns autores ${ }^{3}$ identificaram na estratégia desenhada pelo governo Collor um conjunto de duas vias de medidas, que deveriam caminhar juntas para gerar as condições previstas em seu novo modelo de desenvolvimento: um grupo de ações de estímulo à concorrência, que corresponderiam à liberalização e extinção da proteção anterior, e outro para o desenvolvimento da competitividade da economia local, composto do novo grupo de incentivos e marco de política industrial a ser adotado. Cassiolato e Baptista chegam a afirmar que esses dois grupos de medidas apresentavam incoerências entre si, inclusive no plano teórico (elementos liberais e neoschumpeterianos), o que teria levado ao fracasso de sua completa implementação. (CASSIOLATO E BAPTISTA, 1996, p. 61).

Considerando o cenário econômico e o referencial teórico e político adotado, era óbvio que a antiga política de informática não tinha maiores condições de sobrevivência, ao menos não nos moldes em que foi desenvolvida na década anterior. O novo governo passou a discutir e realizar as alterações que entendia necessária para encaminhamento do

\footnotetext{
${ }^{3}$ CASSIOLATO E BAPTISTA, 1996, e TAPIA, 1995, pp. 23-24.
} 
fim da antiga política e formação de um novo marco institucional de incentivos para o setor, baseado em uma nova racionalidade e com objetivos condizentes com a PICE.

\section{$\underline{3.2}$ O início da discussão sobre a reformulação da política}

Ao propor a liberalização do comércio externo e a defesa da concorrência internacional, os formuladores da PICE certamente tinham na política de informática um de seus alvos centrais. A antiga política e o setor eletrônico são expressamente mencionados nas diretrizes como um dos setores que deveriam ser abertos à concorrência. No documento evita-se realizar uma crítica mais contundente à antiga política, argumentando simplesmente que ela "completou a totalidade do seu ciclo de vida", e que seria necessária uma completa reformulação, uma vez que uma modesta flexibilização seria insuficiente tendo em vista os objetivos pretendidos. O MEFP ficou encarregado da elaboração da proposta da nova política a ser adotada.

O governo foi bem eficiente ao transmitir sua mensagem. Seja pelo desejo de modernização ou pelo real esgotamento do momento da política anterior, em pouco tempo a abertura de mercado já era tida como inevitável e até mesmo desejável pelas empresas do ramo no Brasil ${ }^{4}$, e muitas delas já começavam a se preparar para a nova etapa com novos produtos e negociando novos acordos com parceiras estrangeiras.

O consenso e aceitação, no entanto, restringiam-se à generalidade da proposta. Não havia uma definição clara sobre os termos em que se daria a abertura, nem um cronograma definido para sua implementação. Essa situação, por sinal, caracterizou todo esse momento de discussão da nova política. Nesse sentido, Tapia afirma que, embora fosse enérgico o tom dos primeiros pronunciamentos e também fosse grande o voluntarismo demonstrado pela nova equipe de governo, a concretização da proposta de reforma da legislação referente ao setor de informática demorou. $\mathrm{Na}$ verdade, houve um descompasso entre o anúncio das diretrizes gerais, liberais, que deveriam nortear a PICE e o detalhamento das propostas. Isso gerou, de um lado, uma grande dose de incerteza e, de outro, um espaço de mobilização e de articulação dos vários interesses envolvidos. (TAPIA, 1995, p. 291).

\footnotetext{
${ }^{4}$ Nesse sentido atestam alguns artigos e publicações opinativas da época, como por exemplo ROCHA, 1990 : “Antes de tudo, é preciso deixar claro: a maioria dos empresários do setor de informática é favorável a uma abertura gradual e planejada do mercado para produtos importados” e SOUZA NETO, 1990.
} 
As discussões do período foram capitaneadas especialmente pela nova SCT, o MEFP, e em um terceiro pólo estavam as empresas do setor, agrupadas em associações como a ABICOMP. As discussões giravam em torno de alguns temas recorrentes: o cronograma da abertura (gradualismo ou choque de exposição), lista de produtos que permaneceriam protegidos, flexibilização das regras para licenciamento de tecnologia externa e as associações (joint ventures) com parceiras estrangeiras.

O MEFP foi durante algum tempo o defensor das idéias liberalizantes do governo Collor. Nesse sentido, era o que tinha postura mais radical quanto ao desmonte da antiga política. Seu plano era, nos termos da PICE, provocar um choque de competitividade na indústria de informática, através de uma rápida abertura e da extinção das competências dos diversos órgãos governamentais sobre a importação e fabricação de equipamentos. $\mathrm{Na}$ outra ponta encontravam-se as empresas do setor e suas associações de representação, que sabiam já não fazer mais qualquer sentido em defender a reserva de mercado. Sua batalha passou a ser pela transição gradual e seletiva, que levasse em consideração os nichos de mercado nos quais as empresas tivessem maior competitividade, estimulando-os com alguma proteção remanescente, enquanto os demais seriam liberados, ajudando inclusive no barateamento de insumos e componentes. Conforme Tapia, para os grandes grupos nacionais de informática, a abertura gradual era a forma adequada para alterar a política, principalmente porque ela ampliava o período de vigência da lei e, desse modo, aumentava o poder de barganha ante os parceiros multinacionais no processo de constituição de jointventures. (TAPIA, 1995, p. 296).

Havia, portanto, uma contradição básica entre o que pretendia o governo (e o MEFP) e as idéias do empresariado nacional sobre o assunto. Ainda que aceitasse a abertura econômica, o setor, talvez acostumado a um órgão decisório de grande poder como a SEI, desejava um papel ativo do Estado nesse processo, protegendo e incentivando os grupos nacionais nesse novo cenário. A intervenção estatal seria certamente menor, mas para a maioria da indústria isso não significava que o governo deveria se tornar um agente neutro e indiferente à concorrência no setor. Por esse motivo, brigavam por uma lista ampla de produtos que continuariam protegidos por algum tempo ${ }^{5}$, por regras de incentivos

\footnotetext{
${ }^{5}$ Noto que, conforme Tapia (1995, p. 309), a indústria não estava unida em torno de uma única proposta, havendo divergências entre as associações de representação do setor quanto à lista de produtos, principalmente acerca dos critérios utilizados para sua elaboração.
} 
e subsídios para as empresas nacionais, e alguma restrição às empresas estrangeiras que lhes dessem poder de barganha em seus acordos de associação. Já o MEFP, na esteira da PICE, tencionava exatamente o contrário: excluir o Estado desse jogo. Dessa forma apenas as empresas realmente competitivas sobreviveriam, os preços dos produtos cairiam e a qualidade tenderia a aumentar. Ao governo bastava realizar suas tarefas básicas, mantendo a estabilidade macroeconômica e fortalecendo o "ambiente favorável de negócios" citado na PICE.

A posição intermediária era ocupada pela recém-constituída Secretaria de Ciência e Tecnologia - SCT e seu secretário José Goldemberg. O secretário tentava negociar com a indústria uma transição para o livre mercado, buscando uma alternativa que agradasse igualmente os técnicos do MEFP. Havia algum grau de consenso entre a SCT e a indústria, especialmente no que tange ao gradualismo das reformas e da flexibilização das regras para associações. Esses dois grupos tentaram concertar uma aliança, a fim de preservar algumas das conquistas do período da reserva de mercado. Entretanto, essa aliança foi enfraquecida por divergências quanto a questões menores, como a lista de produtos a serem protegidos e o prazo remanescente dessa proteção.

As primeiras alterações realizadas pelo novo governo diziam mais respeito aos órgãos responsáveis pela política, não sendo muito substantivas em si. No bojo da reforma administrativa que tomou corpo com a Lei 8.028/90, o antigo CONIN, antes ligado diretamente à Presidência da República, passou a estar vinculado à SCT. O órgão seria ainda alvo de uma segunda reforma, dessa vez em sua composição. Apesar de meramente formais, essas alterações traduziam importantes recados e preocupações do governo. Ao retirar do CONIN sua posição de órgão ligado diretamente à presidência, o governo passava a idéia de que o setor deixara de ter a prioridade com que fora considerado anteriormente. A política de informática e sua proteção não constituíam uma preocupação central do governo Collor, e sua adequação às exigências da PICE era muito mais importante do que a lógica da própria política. Em segundo lugar, a maior interferência na composição do conselho garantia ao governo a maioria dos votos, assegurando que a nova orientação comercial da PICE seria efetivamente implementada e que qualquer ação contrária à nova orientação seria impedida por seus representantes. 
Mas a mais simbólica dessas alterações ocorreu quando do lançamento do Programa de Apoio à Capacitação Tecnológica da Indústria em setembro de 1990. Dentre uma série de mudanças anunciadas na orientação do governo quanto à informática, como a criação de uma comissão para rever a lei do software e proposta de emenda constitucional para alteração do conceito de "empresa nacional" da Constituição Federal', o governo adota a Medida Provisória 222/90, extinguindo a outrora poderosa SEI, e criando em seu lugar o Departamento de Política de Informática e Automação - DEPIN, que juntamente com o CONIN herdaria suas competências ${ }^{7}$. A SEI era o órgão que mais se identificava com a antiga política e sua orientação. Sob o controle do CSN, era dotada de grande prestígio, e tinha agregado amplas competências para formular e implementar a política de informática. Representava o esforço e a prioridade dada pelo governo militar a essa área e à capacitação tecnológica local. Extinguir a "instituição SEI" era de fundamental importância para sepultar esperanças quanto à renovação de uma política intervencionista nos moldes da década de oitenta.

À parte dessas reformas nos órgãos responsáveis, as principais discussões sobre a política de informática no período referiam-se à lista de produtos liberados para importação, e as regras para associações (joint-ventures). A idéia de elaboração de uma lista com produtos e componentes que poderiam ser livremente adquiridos no exterior parte das noções de transição e gradualismo cultivadas e discutidas pela SCT e pelas empresas e suas associações. Seus principais objetivos seriam incentivar e preparar a concorrência com alguns produtos estrangeiros, e diminuir o custo de alguns insumos e componentes com preços mais competitivos no mercado externo, aumentando assim a própria competitividade dos produtos finais das empresas brasileiras. A idéia da lista acabou por evoluir para seu contrário: ao invés de uma lista taxativa com os produtos a serem liberados, a lista passaria a listar apenas aqueles que permaneceriam protegidos, com seu respectivo cronograma de liberação; todos os demais equipamentos e componentes estariam automaticamente liberados para importação. Essa interpretação foi posteriormente consolidada no Decreto 99.541/90, segundo o qual ficava a cargo do CONIN a elaboração da lista de produtos que dependeriam da anuência prévia da SCT para importação.

\footnotetext{
${ }^{6}$ Conforme: O GUARDA-CHUVA se fecha. Exame Informática, 3.10.90, n. 10, pp. 4-6.

${ }^{7}$ A MPV 222/90 foi convertida na Lei 8.090/90, que segue a mesma estrutura e texto, com algumas alterações (a lei transfere as competências da SEI para a SCT e não para o DEPIN, como fez a medida provisória).
} 
Conforme acordo entre algumas empresas do setor e SCT, aquelas ficariam encarregadas da elaboração de uma primeira versão da lista. A minuta elaborada revela bem a posição temerosa que a indústria tinha naquele momento. A lista tinha em torno de 300 produtos a serem protegidos, com cronogramas que iam até 1994 (dois anos após o término da reserva previsto na Lei 7.232/84). Mesmo o secretário da SCT Goldemberg, um partidário da transição gradual, apresentou posição radicalmente contrária à lista, afirmando que a proposta era uma renovação da reserva, indo muito além da lei ${ }^{8}$. Após diversas discussões envolvendo associações do setor e de usuários de informática, o CONIN finalmente aprova uma lista definitiva de produtos em outubro de 1990.

Já a questão das associações foi resolvida pelo CONIN sem maiores polêmicas ou divergências. Com a Resolução 19/90 o CONIN passou a admitir as joint-ventures tecnológicas - isto é, o parceiro estrangeiro poderia ser detentor da tecnologia - procurando dessa maneira estimular as associações entre nacionais e multinacionais. Porém, a flexibilização não extinguiu totalmente os dispositivos de regulação da atuação das empresas estrangeiras. As empresas nacionais ainda tinham que preencher alguns requisitos mínimos indispensáveis para que as associações pudessem ser celebradas. Dentre esses requisitos estavam o porte econômico da empresa nacional compatível com a linha de produtos proposta, o adequado percentual de seu faturamento aplicado em atividades de pesquisa e desenvolvimento, a disponibilidade de outros produtos e de processos de produção desenvolvidos com tecnologia própria ou de terceiros, e a liberdade para usar outras fontes de tecnologia. (TAPIA, 1995, p. 304).

\subsection{O debate no Congresso Nacional}

Um primeiro ponto a retomar antes de entrar no debate sobre a nova legislação são alguns dos limites temporais e institucionais da antiga política. A Lei 7.232/84 estabelecia uma série de instrumentos e medidas que, conjuntamente, formariam o quadro de incentivos e proteções da antiga política (o artigo $4^{\circ}$ da lei lista 10 desses instrumentos). A reserva de mercado, ou controle de importações de bens e serviços (conforme inciso VIII), era um deles, e se encontrava expressamente prevista.

\footnotetext{
${ }^{8}$ Conforme: O GUARDA-CHUVA se fecha. Exame Informática, 3.10.90, n. 10, pp. 4-6.
} 
Conforme mencionado no capítulo anterior, a explicitação da reserva de mercado na lei foi fruto de um grande concerto entre forças políticas, e uma das condições era que a lei deveria estabelecer igualmente uma limitação temporal para essa proteção. O prazo foi então acordado para 8 anos, o que representava a vigência da reserva até outubro de 1992.

Outro cronograma ou limitação temporal referia-se ao PLANIN. Nos termos da lei, uma nova versão do plano deveria ser enviada ao Congresso Nacional a cada 3 anos. $\mathrm{O}$ PLANIN era o documento que explicitava as medidas a serem tomadas pela administração pública federal no período, a fim de atingir os objetivos e observando os preceitos da política de informática previstos na 7.232/84.

O I PLANIN havia sido aprovado pela Lei 7.463/86, durante a vigência da antiga política. Sua vigência, que deveria ter se encerrado em 1989, foi sucessivamente renovada pela ausência de um novo plano. Duas leis anteriores, datadas de 1989, já haviam renovado o I PLANIN além de seu prazo inicial. Em 1990, o plano é mais uma vez estendido até novembro, através da Lei 8.070/90.

Talvez seja mais correto interpretar essas limitações temporais dos antigos instrumentos legais como meramente formais, ou sem relevância substantiva mais profunda. Da mesma forma como o I PLANIN foi tantas vezes renovado por períodos curtos, nenhum empecilho legal ou formal impedia que uma nova lei aprovasse uma extensão mais longa, seja do plano ou da própria reserva de mercado. Entretanto, mesmo a mera renovação abria espaço para a discussão desses documentos. Afinal de contas, eles precisavam ser aprovados no Congresso Nacional, e, no caso do PLANIN, também pela SEI e pelo CONIN.

Dessa forma, a expiração do prazo desses documentos foi no mínimo muito conveniente para um governo que tinha em seus planos políticos reformular completamente o modelo anteriormente implantado para o setor. A discussão da matéria encontrava-se na pauta, e isso impedia que a simples inércia política freasse seus planos. $\mathrm{O}$ Congresso Nacional teria que discutir a política de informática. Estava armado, portanto, o fórum na qual seriam travados os debates da nova política. Obviamente isso não significava sucesso automático, uma vez que seria preciso acordar com as forças políticas do congresso as propostas reformistas da equipe econômica de Collor. 
Com a extinção da SEI em setembro de 1990, a elaboração de um II PLANIN para aprovação do CONIN ficava a cargo da SCT. O Projeto de Lei 2 seria entregue à câmara dos deputados em fevereiro de 1991, contendo a proposta do II PLANIN. Já o MEFP e os favoráveis à abertura rápida apresentaram em outubro de 1990 o Projeto de Lei 5.804, que, não obstante seu reduzido número de artigos (apenas 5, na redação original), era suficientemente amplo para alterar as bases da política. Nesse projeto, o governo fixava o prazo final de vigência do controle das importações e das licenças de fabricação até outubro de 1992. Tapia nota que a definição específica da data em que terminaria a reserva de mercado era importante para fechar de uma vez qualquer possibilidade de sua prorrogação. Apesar de, quando da promulgação da Lei 7.232/84, ter sido firmado um compromisso fixando a proteção em oito anos, a redação do artigo $8^{\circ}$, inciso $\mathrm{V}$, deixava a porta aberta para uma possível renovação9. (TAPIA, 1995, p. 311).

É relevante ainda destacar as repercussões de toda essa indefinição do período no setor e em sua produção industrial. O firme discurso proferido pelo governo Collor no primeiro semestre do ano de 1990 ainda não havia se concretizado, ao menos não plenamente. Instalou-se assim um clima de grandes incertezas que teve impacto na indústria. A isso se aliavam as esparsas reformas institucionais nos órgãos responsáveis pela política, que haviam sido pouco debatidas ou acordadas com os empresários. Era um cenário que não favorecia o planejamento empresarial, em momentos em que o que não faltavam eram turbulências na macroeconomia brasileira. Estava claro para a indústria que não valia a pena pleitear ou sequer esperar a manutenção da reserva de mercado.

Representantes e executivos da indústria reclamavam da falta de regras claras em torno das quais pudessem traçar seus planos para atingir esse objetivo. A falta dessas definições, combinada com o ambiente recessivo, fazia com que os fabricantes se encontrassem às cegas durante esse período, adotando as mais diversas estratégias tecnológicas e empresariais, sem saber ao certo se eram condizentes com o marco regulatório e a política a ser adotada. O então diretor da ABICOMP afirmava que cerca de

\footnotetext{
${ }^{9}$ A esse respeito, nota-se que surgiram à época vozes e teorias de que a reserva de mercado persistiria após o prazo de outubro de 1992, mesmo que não houvesse qualquer renovação ou alteração legislativa. O jurista Eros Roberto Grau defendeu essa tese em artigo publicado à época. Em breves palavras, afirmava o autor que o prazo de oito anos referia-se exclusivamente ao "controle prévio" das importações pela SEI, e não à prerrogativa do Poder Executivo para adotar quaisquer restrições à importação, para assegurar proteção às empresas nacionais. (GRAU, 1990).
} 
15 mil empregos foram cortados de setembro de 1990 a abril do ano seguinte, decorrente da queda da atividade industrial. Em um artigo bem crítico publicado à época, dizia que “(...) o que deveria ser um processo de transição controlada, que preservasse os investimentos já feitos na indústria e os milhares de postos de trabalho que foram criados, transformou-se numa batalha dos que acreditaram no governo e investiram no setor, contra os que se aproveitaram da inércia policial e agora posam como empresários de sucesso(...)”. (CAMPOS, 1991).

Certamente essa é uma das lições sobre implementação de políticas públicas a serem apreendidas estudando este período. O governo Collor de Mello demonstrou inabilidade em conduzir um cenário de transição, em diminuir incertezas e dar sinais claros de suas intenções que efetivamente pudessem se traduzir em estratégias de negócios pelas empresas locais.

Estando as duas propostas formalizadas em projetos legislativos, o locus de debate e negociação deslocou-se do âmbito do Poder Executivo para o Legislativo. Como ocorreu em 1984, mais uma vez o Congresso debateria os rumos do setor de informática no país, e qual seria a posição do poder público nesse desenrolar. Um personagem marcaria sua presença e importância mais uma vez, reiterando boa parte daquilo que dissera sete anos antes: o então deputado federal Roberto Campos.

O debate na câmara dos deputados se deu principalmente entre dois projetos alternativos que representavam as duas visões distintas para a política a ser seguida na década de noventa. É interessante notar que enquanto as divergências entre o MEFP e a SCT se davam mais acerca dos termos da transição, na Câmara dos Deputados o debate apresentou uma densidade maior. As discussões referiam-se ao papel pretendido para o Estado no desenvolvimento desse setor.

O primeiro projeto era a versão original do PL 5.804/90 apresentada pelo executivo e assinada pela ministra Zélia Cardoso de Mello e pelo secretário da SCT José Goldemberg. Limitava-se a reiterar o prazo fatal da reserva de mercado como outubro de 1992, extinguia na mesma data os incentivos fiscais da Lei 7.232/84, e alterava o conceito de empresa nacional. A concisão do projeto pode ser explicada pelo viés liberal dessa opção, conforme a intenção do governo Collor bem delineada na PICE. Seu objetivo 
resumia-se em acabar com as proteções e incentivos que, conforme essa visão, distorciam e impediam o livre acesso e concorrência no mercado de informática brasileiro. Não se tratava de formular uma nova política, bastando, para atingir seus objetivos, alguns poucos artigos que revogassem dispositivos considerados protetores ou criadores de privilégios.

A proposta alternativa foi formulada no âmbito da Comissão de Ciência, Tecnologia, Comunicação e Informática da Câmara dos Deputados - CCTCI pelo deputado Luiz Henrique (o chamado substitutivo Luiz Henrique). O parecer ataca a proposta do governo, por extinguir uma política "sem apresentar alternativas que resguardem o patrimônio nacional, constituído por mais de 300 empresas nacionais, e mais de 50 mil empregos (sendo 15 mil de nível universitário e pós-universitário) (...)” ${ }^{10} \mathrm{O}$ projeto Luiz Henrique apresentava uma preocupação com a construção e manutenção de capacitação tecnológica nacional, o que revela uma visão partidária de uma política industrial abrangente e, segundo descrito, teria sido elaborado em diálogo com diversos segmentos do setor de informática, buscando atender a seus anseios e preocupações com o fim da reserva. Sua idéia era estabelecer um novo marco regulatório de incentivos que suprisse o vazio gerado pela extinção da política anterior. Seria instituída, assim, uma nova política de informática, e não apenas destruída a anterior, como a opção do primeiro projeto.

Analisando o texto do projeto, nota-se diversas semelhanças e pontos em comum com as medidas adotadas até o início da década de noventa, o que pode representar uma certa intenção continuísta ou de rejeição às mudanças propostas do governo Collor ${ }^{11}$. Os incentivos fiscais são um ponto chave do projeto. O deputado Luiz Henrique apresenta como algumas das justificativas para sua implantação: apoio à capacitação tecnológica nacional, incentivo à competitividade à empresa brasileira de capital nacional, incentivo à comercialização de bens de informática produzidos no país, incentivo ao usuário de bens e

\footnotetext{
${ }^{10}$ Conforme publicado no Diário do Congresso Nacional, Seção I, 20.6.1991, p. 10333.

${ }^{11}$ Os principais pontos do projeto eram: (i) manutenção das joint-ventures ou associações com empresas estrangeiras, sendo resguardadas, no entanto, algumas restrições e exigências, como composição de capital, investimento em pesquisa e desenvolvimento e alto nível tecnológico do objeto da parceria; (ii) reconhecimento da importância do capital externo, mantendo requisitos para sua entrada como índices de performance, relacionados a investimentos em pesquisa e desenvolvimento, exportação e capacitação técnica; (iii) "política ativa", traduzida na utilização do poder de compra estatal, dando preferência às empresas de capital nacional, e em incentivos fiscais; (iv) são mantidos ou renovados uma série de isenções e reduções fiscais para as empresas brasileiras de capital nacional, exigindo em contrapartida que as empresas invistam $5 \%$ de seu faturamento bruto em pesquisa e desenvolvimento; (v) o CONIN é reinstituído como órgão de primeiro nível governamental, composto por diversos ministérios e chefiado pelo Presidente da República (neste ponto fica nítida a intenção do projeto de volta ou manutenção da antiga política de informática).
} 
serviços de informática projetados e produzidos no país, e incentivo à microeletrônica e ao software. Nota-se portanto que o substitutivo Luiz Henrique pretendia uma atuação ativa do Estado promovendo a indústria local, com a concessão de incentivos e proteções. A importância conferida ao papel do Estado é tamanha que se chega a mencionar que a reserva de mercado só não é novamente proposta devido às restrições do GATT ("sem poder repetir as normas de anuência prévia, disponho, no entanto, (...)"12.

Mas os relatos das discussões da Câmara mostram que pouco se debateu sobre esse assunto, o que pode significar algum grau de consenso sobre a inviabilidade ou inconveniência na perpetuação da reserva. Algumas poucas exceções foram as declarações de voto dos deputados Ernesto Gradella e Cidinha Campos, que argumentaram contra a dependência tecnológica e entendiam ser a reserva de mercado um mecanismo para evitar a submissão nacional a interesses externos.

Principal expoente do bloco liberal, Roberto Campos iniciou a defesa do projeto do governo atacando a reserva de mercado, e dizendo que este projeto garantiria em curto prazo a liberalização esperada do mercado de informática e a inserção do Brasil no contexto mundial do progresso. Com a combatividade e firmeza típica de suas falas, posicionou-se duramente contra o substitutivo Luiz Henrique, acusando-o de "xenófobo, retrógrado e ingênuo, sob o ponto de vista das realidades de mercado (...)"13. Afirmava ainda que o projeto inviabilizava a atração de novas empresas de capital estrangeiro, devido à discriminação frente às empresas de capital nacional no tocante às compras do poder público e aos financiamentos e incentivos oficiais. A dureza das palavras revela o quanto Roberto Campos e, juntamente com ele, a ala liberal do congresso e do governo, entendia o substitutivo um retrocesso. Conforme sua conclusão,

\footnotetext{
“esse projeto é o suicídio tecnológico para o Brasil. Já estamos atrasados, e esse atraso será melancolicamente confirmado. (...) O substitutivo da Comissão de Ciência e Tecnologia, Comunicação e Informática, porém, é anticientífico e antidemocrático. Cria uma Gestapo tecnológica e uma humilhante alfaiataria cambial. Com ele, o Brasil estará fora do mundo". ${ }^{14}$ (grifo nosso)
}

Do outro lado, deputados favoráveis ao substitutivo Luiz Henrique atacaram a proposta do governo por ser excessivamente liberal e não se preocupar com o

${ }^{12}$ Conforme Diário do Congresso Nacional, Seção I, 20.6.1991, p. 10333.

${ }^{13}$ Conforme Diário do Congresso Nacional, Seção I, 26.6.1991, p. 11320.

${ }^{14}$ Conforme Diário do Congresso Nacional, Seção I, 26.6.1991, p. 11320. 
desenvolvimento tecnológico local. Citando trecho anedótico do discurso proferido pelo deputado Aloizio Mercadante, “o outro caminho é o do neoliberalismo, defendido pelos que entendem que modernidade é o Frei Damião andando de jet ski, que modernidade é simplesmente transformar-se a economia brasileira num supermercado de produtos sofisticados". ${ }^{15}$

À parte dos diversos ataques do gênero à postura liberalizante do projeto original do governo, os parlamentares favoráveis ao substitutivo ressaltaram, como argumentos a seu favor, a necessidade de alguma medida para o período de transição de uma economia fechada a um cenário aberto, e a importância do resguardo da capacidade tecnológica e comercial construída através de uma política industrial ativa.

Diversas referências são feitas a um amplo acordo de forças políticas para aprovação do substitutivo Luiz Henrique, reflexo do diálogo mantido entre parlamentares e atores do setor (em discurso proferido pelo deputado Genebaldo Correia é mencionado que esse acordo abrangia todos os partidos políticos da câmara, com exceção do PDS de Roberto Campos e do PDT) ${ }^{16}$. Em função desse acordo, alguns pontos do projeto inicial foram alterados, flexibilizando as restrições e exigências ao capital externo, a fim de evitar confrontos diretos com o governo e atrair para o substitutivo parlamentares governistas que consideravam a proposta anterior demasiado rígida.

A votação na Câmara dos Deputados foi confusa e longa, com cada um dos grupos desejando colocar o seu projeto em pauta primeiro, para assim obstruir a votação da alternativa. Um sem-número de destaques foi também apreciado no dia da votação, que trouxeram algumas alterações ao projeto original - sendo um dos mais relevantes a supressão da exigência de metas de exportação de $25 \%$ do faturamento bruto para empresas estrangeiras operarem no país.

Com tais alterações, o substitutivo Luiz Henrique foi aprovado pela câmara dos deputados, e enviado ao Senado Federal. O Senado apresentou 10 emendas, que pouco alteravam o espírito e as disposições mais controvérsias do projeto. Uma das relevantes alterações foi a introdução de um dispositivo exigindo que $40 \%$ da verba destinada a

${ }_{16}^{15}$ Conforme Diário do Congresso Nacional, Seção I, 26.6.1991, p. 11321.

${ }^{16}$ Conforme Diário do Congresso Nacional, Seção I, 26.6.1991, p. 11332. 
pesquisa ( $5 \%$ do faturamento bruto) fossem aplicados em centros de pesquisa ou institutos de pesquisa ou de ensino brasileiros. A grande maioria das emendas foi aprovada pela câmara, e o projeto seguiu para sanção presidencial.

Em 23 de outubro de 1991, o presidente Collor de Mello sanciona a Lei 8.248/91, que constituirá a nova Lei de Informática, apresentando 4 vetos ao substitutivo. O mais importante foi o veto ao parágrafo que estabelecia condições para uma empresa que não preenchesse os requisitos exigidos para ser considerada empresa brasileira de capital nacional, sob alegação de que conceder ao CONIN esse poder seria criar uma nova “reserva de mercado". Os vetos de Collor tornaram a nova Lei de Informática mais liberal, na medida em que o governo abriu mão da exigência do atendimento de alguns requisitos por parte das empresas multinacionais para que pudessem pleitear os incentivos previstos na legislação. Mesmo assim, as linhas básicas da nova lei exprimiram o acordo firmado entre técnicos do governo, as lideranças empresariais e os partidos políticos.

Considerando esse histórico, a Lei 8.248/91 é possivelmente melhor compreendida se encarada como o resultado final de diversos acordos entre forças políticas com visões e interesses conflitantes. Tirando o ramo marcadamente liberal representado pelo PDS e o protecionista especialmente pelo PDT, os demais grandes partidos e atores chegaram a um consenso que pudesse razoavelmente satisfazer a todos. Isso, obviamente, não era totalmente satisfatório para ninguém. Em seu discurso, o deputado Ricardo Fiúza deu declaração que poderia ser estendida aos demais membros da câmara que votaram favoravelmente ao substitutivo: "devo deixar claro que a posição do Bloco é fechar com o relatório do Deputado Luiz Henrique. Posso apenas fazer o comentário de que não é a lei dos meus sonhos, mas acho que dentro da negociação política é o melhor que podemos fazer, pois ela avança bastante" ${ }^{17}$.

Sendo resultado de um acordo do gênero, a lei vai se revelar problemática em diversos aspectos. Tapia apresentou críticas a seu conjunto de dispositivos, tratando-a como "conjunto esquizofrênico de medidas". (TAPIA, 1995, p. 319).

${ }^{17}$ Conforme Diário do Congresso Nacional, Seção I, 26.6.1991, p. 11331. 
3.4 Principais normas e regras; os primeiros anos da nova Lei de Informática

Conforme mencionado, desde a apresentação do primeiro substitutivo do deputado Luiz Henrique até a sanção presidencial diversas alterações foram feitas ao projeto. Embora seja artificial afirmar que haja alguma linearidade nessas modificações, em linhas gerais elas tenderam a flexibilizar a política instituída, possibilitando a conciliação entre os ímpetos liberalizantes do governo Collor de Mello e os interesses e posições dos setores nacionalista e do empresariado do ramo. Retomo em breves linhas como ficou a redação final da Lei 8.248/91, anotando seus pontos centrais.

(i) Explicitação do fim da reserva de mercado em 29.10.1992.

(ii) Definição de empresa de capital nacional: adotou-se o conceito constante na Constituição Federal (artigo 171), com o requisito adicional de seu parágrafo $1^{\circ}$, inciso II (setor imprescindível ao desenvolvimento tecnológico nacional). Assim, para se enquadrar nessa definição, $51 \%$ do capital votante deveria estar nas mãos de residentes no país, além do exercício do poder decisório para atividades sociais, incluindo aquelas de natureza tecnológica.

(iii) Isenção de IPI para os bens com níveis de valor agregado local compatíveis com as características de cada produto, conforme definido pelo poder executivo, por proposta do CONIN, até outubro de 1999.

(iv) Poder de compra do governo: preferência da administração pública federal, na aquisição de bens e serviços de informática, às empresas brasileiras de capital nacional com produtos desenvolvidos a partir de tecnologia local (ou, em segundo lugar, apenas produzidos no país).

(v) Prioridade às empresas de capital nacional para financiamentos diretos e indiretos concedidos por instituições financeiras federais ou seus repasses, para custeio dos investimentos em ativo fixo, ampliação e modernização industrial.

(vi) Dedução do valor gasto com pesquisa e desenvolvimento no valor devido de IR, até o limite de 50\%, até o ano de 1997. 
(vii) Todas as empresas do país poderiam deduzir do IR devido o valor de ações de empresas brasileiras com capital nacional dedicadas à atividade de informática adquiridas, até o limite de $1 \%$, desde que as ações fossem novas e inalienáveis pelo prazo de 2 anos (também válido até o ano de 1997).

(viii) Como contrapartida aos benefícios mencionados, as empresas de informática deveriam investir 5\% de seu faturamento bruto no mercado interno de bens e serviços de informática em atividades de pesquisa e desenvolvimento, conforme projeto elaborado pelas próprias empresas. No mínimo $2 \%$ deveriam ser aplicados em convênios com centros ou institutos de pesquisa ou entidades brasileiras de ensino, oficiais ou reconhecidas.

(ix) As empresas estrangeiras deviam, ainda, atender a outras duas condições: investir na capacitação de seu corpo técnico e cumprir um programa de exportação.

O II PLANIN foi aprovado também em 1991, um pouco antes da nova Lei de Informática. O plano foi aprovado pela Lei 8.244/91, e começa por traçar um quadro do setor nacional naquele momento. A informática é então considerada um setor importante e estratégico para o desenvolvimento nacional, apresentando externalidades positivas e convergências com a modernização e aumento da produtividade de outros setores. Reconhece-se a importância da política de informática anterior, considerando a indústria nacional madura e em fase de consolidação, apesar de ainda não apresentar preços e qualidade compatíveis com o mercado externo. Um terceiro aspecto importante do cenário traçado é que, apesar do desenvolvimento da indústria, a sociedade brasileira não havia se informatizado, havendo pouca demanda e uso de produtos de informática. Isso demandaria um esforço para introdução dessa tecnologia na vida comercial e privada das pessoas e empresas, e formação de usuários e técnicos que demandariam produtos e modernizariam outros setores.

Com base nesse quadro são traçados três objetivos do II PLANIN, que são a melhoria e aumento da competitividade da indústria nacional (para competição no mercado externo), o desenvolvimento tecnológico, entendido como a capacidade de gerar, desenvolver, aperfeiçoar, absorver e selecionar tecnologias, e informatização da sociedade brasileira. As estratégias apresentadas para atingir esses objetivos se encontram em 
consonância com as diretrizes da PICE: abertura econômica, diminuição do papel do Estado e focalização de incentivos e programas. As principais medidas estão voltadas à generalização do uso da informática, à busca de competitividade da produção, ao estímulo a pesquisa e desenvolvimento, e à formação de recursos humanos na área.

A partir da aprovação do II PLANIN e da Lei de Informática, a indústria lançou-se em um momento de espera e preparação. Até outubro de 1992, o que se viveu foi um interregno, no qual a antiga política já tinha seus dias contados, e a nova ainda não começara. Essa situação trouxe duas grandes repercussões: um desaquecimento ainda mais forte do mercado (que já estava degradado) e a aceleração do processo de associações com empresas estrangeiras.

A desaceleração do mercado foi decorrência em grande parte da expectativa dos consumidores sobre o que ocorreria após a abertura. Após aproximadamente uma década e meia de reserva, esperava-se que em breve estariam à disposição equipamentos e produtos muito mais avançados tecnologicamente, a preços substancialmente inferiores. Sob essa lógica fazia todo sentido para a grande maioria postergar suas compras não essenciais para o momento em que esse "portão de entrada" estivesse aberto. Já 1991 trouxe uma forte queda no faturamento, e um setor acostumado a taxas de crescimento anuais da ordem de $30 \%$ sofreu um decréscimo entre $10 \%$ a $20 \%$ nesse ano ${ }^{18}$. Parcela dessa redução também foi devida à queda acentuada dos preços dos equipamentos no período, em parte devido à redução da carga tributária, em especial o IPI, que teve sua isenção determinada desde junho de 1991 (Lei 8.191/91).

As empresas brasileiras sabiam que a sobrevivência após a abertura dependeria crucialmente de sua capacidade de atualização e acesso à tecnologia internacional. Assim, no final de 1991 e primeiro semestre do ano seguinte essas sociedades buscaram fechar ou consolidar acordos e associações com fornecedores e fabricantes estrangeiros. Esse movimento é importante e tratava-se de uma novidade no setor, em especial considerando que tais alianças somente haviam sido permitidas pelo CONIN em 1990. Conforme nota divulgada à época, "o setor pisou fundo também no acelerador do principal mecanismo de escape da indústria nacional no pós 29 de outubro: a associação com fabricantes

\footnotetext{
${ }^{18}$ Conforme reportagem: O FIM da reserva chega mais cedo. Exame Informática, n. 5, maio 1992, pp. 64-66.
} 
estrangeiros, que vai resultar na transferência de tecnologia atualizada e na materialização da livre concorrência" ${ }^{19}$.

Apesar da expectativa e do momento desfavorável para a indústria, a abertura de mercado em 1992 não significou o fim do período de transição entre as políticas, nem da indefinição que o caracterizou. Isso porque uma regulamentação mais completa da Lei 8.248/91 somente ocorreu em 1993, através do Decreto 792/93. O decreto estabelecia que os bens que fariam jus à isenção de IPI seriam listados em portaria conjunta do MCTe do MINIFAZ, por proposta do CONIN, levando em consideração os seguintes indicadores: valor agregado local, qualidade (certificação e observância às normas e padrões internacionais), preço compatível com o similar importado, competitividade internacional, e capacitação tecnológica da empresa. As empresas poderiam requerer ao MCT a inclusão de novos bens na lista de isenções, justificando a adequação a esses indicadores.

A regulamentação necessitava ainda de uma portaria interministerial que esclarecesse e definisse expressamente qual seria o nível de agregação exigida dos produtos. Como até então as empresas usufruíam da isenção de IPI sem qualquer contrapartida nesse sentido, o tema foi objeto de muita discussão entre indústria e governo. A Portaria Interministerial do MCT e do MICT 101/93 é promulgada alguns dias após o decreto regulamentador. O termo "processo produtivo" é utilizado pela primeira vez nesse contexto para definir o nível de agregação de valor necessário para fruição dos benefícios. Sem entrar nas especificidades técnicas da portaria, a maioria dos processos produtivos definidos faz referência à montagem ou solda de partes e peças (o chamado CKD complete knock-down). A portaria exige ainda das empresas a obtenção de um certificado de qualidade da ABNT.

Um dos temas muito debatidos quando do lançamento da portaria referia-se à necessidade de montagem local de placas (as chamadas motherboards). Essa discussão ilustra bem o impasse que esse tipo de regulamentação criava entre empresas e governos. Muitas empresas criticaram a exigência do MCT, alegando um forte impacto no preço final de seus produtos, além da conseqüência final do aumento do contrabando (as placas eram então os principais itens do comércio ilegal de produtos de informática no país). O

${ }^{19}$ Conforme reportagem: O FIM da reserva chega mais cedo. In Exame Informática, n. 5, maio 1992, pp. 6466. 
governo, em sentido contrário, acenava que esse era o objetivo da Lei de Informática, e que os incentivos não fariam sentido se não houvesse a exigência de algum grau de agregação de valor por parte das empresas, garantindo assim o emprego e alguma capacitação tecnológica local. O MCT referia-se ainda a um plano para tornar o Brasil um pólo exportador de placas, com base nesses e em outros incentivos fiscais ${ }^{20}$.

As divergências entre governo e indústria sobre a montagem das motherboards suscitam uma discussão maior, podendo ser utilizadas como mote para compreender como se alternaram as estratégias de negócios das empresas, e quais as suas novas racionalidades e preocupações. Se antes tais estratégias baseavam-se em uma blindagem ao setor, e na pressão política para manutenção ou prorrogação dessa proteção, nesse segundo momento as restrições passaram a ser incômodas e vistas como verdadeiros entraves aos negócios pelos agentes nacionais do setor.

Outros fatores considerados importantes para compreensão da intensidade e convergência das alterações nas estratégias empresariais são, conforme já explicitado, as indefinições e mesmo contradições nos instrumentos de política que caracterizaram esse período de transição, induzindo à adoção de estratégias altamente defensivas e de curto prazo, assim como a forte recessão que deprimiu as expectativas de vendas ${ }^{21}$. Os resultados e números referentes às escolhas adotadas serão abordadas posteriormente neste capítulo. Por ora, basta salientar que essa alteração de rota não representou um mero ajuste a novas condições institucionais, mas afetou a essência, tanto da política quando dos objetivos traçados pelas estratégias empresariais. Esse movimento podendo ser representado, num tom generalista, como partindo do desenvolvimento e fabricação própria para o mercado interno (nos anos oitenta), até a associação e comercialização de produtos e tecnologia externa, com alguma agregação de valor local exigida em lei, para sobrevivência em um mercado de concorrência que tendia a reproduzir a dinâmica apresentada no mercado internacional.

\footnotetext{
${ }^{20}$ Conforme reportagem: ISENÇÃO de IPI só para quem montar placa. Informática Hoje, n. 331, 29.3.1993, p. 24.

${ }^{21}$ Conforme reportagem: ISENÇÃO de IPI só para quem montar placa. Informática Hoje, n. 331, 29.3.1993, p. 24.
} 


\subsection{O fim da empresa brasileira de capital nacional}

O tratamento diferenciado e os benefícios institucionais e econômicos às empresas de capital nacional atingiram seu ápice com a redação dada ao artigo 171 na Constituição Federal de 1988. Este artigo reiterou, com algumas poucas alterações, a distinção entre essas empresas que já constava na Lei 7.232/84. Estabelecia ainda, em seu parágrafo primeiro, que a lei poderia conceder proteção e benefícios especiais temporários à empresa de capital nacional e estabelecer outras condições e requisitos, como o controle das atividades tecnológicas, quando entender ser um setor imprescindível ao desenvolvimento tecnológico nacional.

A história do artigo 171 da Constituição tem relação muito próxima com a trajetória da política de informática brasileira. Antes da Carta Magna de 1988, não havia qualquer distinção constitucional entre as empresas em razão da nacionalidade de seu capital. A classificação que se utilizava era apenas as de empresas nacionais ou não nacionais, decorrente da Lei das Sociedades Anônimas - Lei 6.404/76, segundo a qual "são nacionais as sociedades organizadas na conformidade da lei brasileira e que têm no país a sede de sua administração" (artigo 300). O artigo 171 veio introduzir uma nova distinção entre empresas brasileiras (cuja definição segue aquela estabelecida na Lei das Sociedades Anônimas) e as empresas brasileiras de capital nacional (controle efetivo direta ou indiretamente nas mãos de residentes no país). Consta que o dispositivo foi redigido com base no artigo 12 da Lei 7.232/84, o que certamente explica a semelhança na redação das duas normas. (BASTOS, 1988, v.7, p. 50).

Os debates jurídicos sobre o artigo 171 faziam freqüente referência e estavam muito relacionados à política de informática. (BASTOS, 1988, v. 7, p. 50). Um dos pontos suscitados quando da promulgação da nova Constituição foi uma possível revogação do artigo 12 da Lei 7.232/84, por trazer mais exigências do que o texto constitucional para caracterização da empresa de capital nacional (as expressões "controle exclusivo e incondicional"). (BASTOS, 1988, v. 7, p. 50). A discussão foi encerrada com a nova Lei de Informática, que trouxe um conceito uniforme com a Constituição.

$\mathrm{O}$ antigo artigo constitucional 171 era um dispositivo que, por encerrar uma proteção, ou uma possibilidade de proteção, às empresas locais, sempre foi objeto de discussão e diversos ataques. Esse processo intensificou-se a partir da década de noventa e 
da emergência de um novo paradigma de política econômica mais ligado à liberalização e abertura comercial, conforme já explicado. Entretanto, o debate e a tentativa de retirar esse artigo da constituição somente ocorreu de fato em 1995, durante o governo Fernando Henrique Cardoso, por iniciativa do Poder Executivo.

O Projeto de Emenda Constitucional - PEC 5/95, na verdade, voltava aos conceitos utilizados anteriormente à Constituição de 1988. A redação proposta para o artigo 171 utilizava a classificação baseada na lei do local de constituição e na localização da sede social da empresa, conforme estabelecido na lei das sociedades anônimas. Deixava-se de distinguir entre empresas brasileiras e empresas brasileiras de capital nacional, com o fim do beneficiamento a essas últimas. Seriam favorecidos apenas os produtos e serviços produzidos ou prestados no país e, ainda assim, apenas se estivessem em igualdade de condições com os seus concorrentes. A justificativa da proposta centrava-se no fim da reserva de mercado. Afirmava que "a discriminação ao capital estrangeiro perdeu sentido no contexto de eliminação das reservas de mercado, maior interrelação entre as economias e necessidades de atrair capitais estrangeiros para complementar a poupança interna"22.

O debate sobre a alteração no Congresso Nacional mobilizou diversas forças políticas e econômicas. Em um esforço de legitimação e democratização do processo legislativo, a Câmara dos Deputados convocou diversas autoridades e representantes da sociedade civil e de interesses empresariais para exporem suas opiniões a respeito do assunto e darem aos parlamentares uma melhor percepção de como o anterior artigo 171 afetava suas atividades e como eles se posicionavam frente à alteração.

Um discurso especialmente relevante para este tema foi proferido pela representante do MCT Simone Scholze, que falou quase exclusivamente sobre a política de informática. Ela citou a nova Lei de Informática como um exemplo de sucesso da abertura econômica, com números acerca da renúncia fiscal e dos investimentos realizados pelos empresários do setor em pesquisa e desenvolvimento. Opinava pela alteração do artigo 171 conforme a proposta do governo, argumentando que "não mais se justifica a preservação de uma política governamental que confira tratamento distinto entre as empresas de capital não nacional, sediadas no país e que, efetivamente, gerem tecnologia, atividade industrial e

\footnotetext{
${ }^{22}$ Conforme publicado no Diário do Congresso Nacional, 15.3.1995, p. 3426.
} 
investimentos, daquelas que apenas por atenderem aos percentuais de nacionalização do seu capital votante e estarem sediadas em território brasileiro são hoje alvo de prerrogativas como empresas brasileiras de capital nacional" ${ }^{23}$.

A PEC 5/95 foi aprovada pelo Congresso Nacional com uma alteração que, sem pretensão de adentrar mais profundamente no tema, pode ser considerada ainda mais liberalizante do que a proposta inicial do governo. O artigo 171, ao invés de ter sua redação alterada, como pretendido, foi simplesmente revogado pelo artigo $3^{\circ}$ da Emenda Constitucional 6/95.

À aprovação da alteração constitucional seguiu-se uma nova discussão, acerca da subsistência dos incentivos específicos da Lei 8.248/91 às empresas brasileiras de capital nacional. $\mathrm{O}$ cerne da controvérsia era se os incentivos estabelecidos na lei permaneceriam válidos a despeito da exclusão do conceito e da expressa permissão constitucional para privilégio a essas empresas.

Para dirimir a questão o MCT aprovou parecer emitido por sua consultoria jurídica, o Parecer CONJUR/MCT-ACF 231/95. Trata-se de documento extenso, que tenta abordar o assunto sob uma perspectiva eminentemente formal e jurídica. $\mathrm{O}$ parecer argumenta pela incompatibilidade desses incentivos específicos com o novo texto reformado da constituição. Dessa forma, o ministério passa a considerar revogados o benefício da capitalização incentivada (redução de IR para as empresas que investissem em sociedades dedicadas à informática), o favorecimento em compras e licitações públicas e a prioridade na obtenção de financiamentos por instituições financeiras ligadas ao governo federal, e as exigências adicionais que eram feitas às empresas estrangeiras para a isenção do IPI (programa de capacitação tecnológica do corpo técnico da empresa e programas progressivos de exportação) $)^{24}$.

É interessante notar que pouco ou nada se menciona no parecer do MCT sobre causas ou repercussões econômicas da extinção dos incentivos ou de sua permanência, e de como o setor seria afetado em qualquer dos casos. O documento passa distante de qualquer

${ }^{23}$ Conforme publicado no Diário do Congresso Nacional, 9.3.1995, p. 2855.

24 Parecer CONJUR/MCT-ACF 231/95. Noto que em parecer posterior (o Parecer CONJUR/MCT-ACF 268/95) o MCT reconheceu como intocável o direito adquirido à redução do IR para as empresas que já tinham realizado investimento em empresas de informática até 1995. 
dessas questões. Constitui, assim, exercício dogmático, tentando encontrar a resposta a essa questão na própria lógica e coerência interna do ordenamento jurídico, podendo certamente ser criticado por isto. Isto porque, conforme já mencionado, as políticas públicas alteram a racionalidade tradicional do direito, sendo introduzido os elementos da finalidade e programa de ação, que são completamente desconsiderados pelo parecer do MCT.

Para o setor de informática, a maior repercussão de toda essa discussão, ao menos no primeiro momento, foi o fim da preferência nas compras governamentais. Anteriormente ao parecer (e à alteração constitucional), o Decreto 1.700/94 estabeleceu uma série de critérios a serem seguidos pela administração que beneficiava bastante as empresas brasileiras de capital nacional. Com a nova orientação, o favorecimento se daria unicamente pelos critérios da tecnologia nacional e da fabricação local conforme o PPB. Tratava-se de uma mudança de grande importância, considerando o peso que tinha e ainda tem o poder público como o grande consumidor de informática no mercado nacional.

A posição do MCT quanto à capitalização incentivada não chegou a ser tema de muitas reclamações, possivelmente devido ao pouco interesse demonstrado pelo benefício desde sua instituição até o ano de 1995. Ainda assim, destaca-se que até 1994 haviam sido captados algo em torno de US\$ 23 milhões, beneficiando 40 empresas de informática e telecomunicações. (AQUINO, 1995).

\subsection{A primeira renovação da Lei de Informática}

No final do exercício de 1997 encerraram-se definitivamente os incentivos de 50\% de IR para empresas de informática e da capitalização incentivada. Apesar de alguma relevância, não se pode afirmar que eram cruciais para a sobrevivência da indústria no país. Prova disso é o pouco número de projetos submetidos ao MCT para esses benefícios durante sua vigência. Apenas 179 de redução de IR (sendo aprovados 107) e 65 de capitalização incentivada (43 aprovados), menos de $20 \%$ do total, lembrando ainda que a maioria dessas requisições também contemplava a isenção de IPI. (SEPIN, 1998, p. 13). Por esse motivo houve pouca movimentação contrária quando do término desses incentivos em 1997, sem considerações mais efetivas acerca de sua prorrogação. 
O mesmo não se pode dizer da isenção de IPI. Inicialmente prevista na Lei 8.248/91 para durar até outubro de 1999, já no ano anterior setores da indústria e do governo começaram a se movimentar para discutir uma renovação dos incentivos. Um projeto de lei nesse sentido tramitava no Congresso Nacional desde 1996 (PL 2.514/96). O então Ministro da Ciência e Tecnologia, Bresser Pereira, foi um dos que defendeu amplamente a renovação dos incentivos, se indispondo com a equipe econômica do Ministério da Fazenda do então presidente Fernando Henrique Cardoso, a quem atribuía a culpa pela delonga na aprovação do projeto. (AQUINO, 1999).

Para embasar os argumentos pró-renovação da lei, alguns estudos foram financiados e publicados pelo governo e pela indústria, abordando os resultados da política e o desenvolvimento do setor no período ${ }^{25}$. Destaco um extenso estudo favorável à política divulgado pelo MCT à época ${ }^{26}$. Neste documento, o ministério utiliza-se de uma série de dados e informações sobre o setor para embasar uma clara opinião favorável à revisão da lei e prorrogação dos incentivos. É uma análise com forte fundamentação empírica, na qual é ressaltada a importância do setor de tecnologia da informação para o desenvolvimento brasileiro e da política durante seus anos de vigência.

O setor é descrito como prioritário para a economia brasileira, como meio capaz de alavancar a modernização e competitividade de todos os setores produtivos da atividade econômica do país e, conseqüentemente, apoiar o seu desenvolvimento econômico e social. Os argumentos centrais utilizados para a defesa da prorrogação são, em breves linhas, os resultados da lei e uma especulação sobre o que poderia ocorrer caso os incentivos deixassem de existir. A base dessa previsão era uma pesquisa da Fundação Dom Cabral com empresas do setor, cujo resultado apresentava argumentos extremamente fortes para manutenção dos benefícios. O estudo mostrava que para a quase totalidade das empresas a isenção de IPI e a redução do IR foram importantes ou muito importantes tanto para a competitividade empresarial como para o desenvolvimento tecnológico, e a extinção desses benefícios teria um impacto significativo ou muito significativo sobre sua atividade tecnológica. Ademais, mais da metade das empresas pesquisadas informaram que caso os benefícios fiscais fossem instituídos pela lei não fossem prorrogados, elas considerariam a

25 A Fundação Dom Cabral efetuou uma pesquisa intitulada "Estudos dos Impactos e Resultados dos Incentivos Fiscais de que tratam as Leis 8.248/91 e 8.661/93", e a revista Informática Hoje faz referência a estudos da ABINEE nesse sentido (ver no artigo de AQUINO, 1999), além do estudo do MCT.

${ }^{26} \mathrm{Na}$ seção 2.9 abaixo realizo uma análise mais detida deste documento do MCT. 
hipótese de deslocar sua produção para a ZFM ou outros países da América Latina. (SEPIN, 1998, p. 27).

Assim como nos princípios da política, o ano de 1999 apresentou-se com dificuldades para a indústria de informática. Mais uma vez as incertezas e problemas internos da política somaram-se a questões relacionadas à conjuntura macroeconômica do país. A desvalorização cambial ocorrida no início do ano afetou sensivelmente os preços praticados pela indústria. Como grande parte dos componentes e peças utilizados na fabricação dos equipamentos vinha do exterior (e tem seu custo vinculado à moeda estrangeira), o preço final ao consumidor acabou subindo, comprimindo as vendas. Considerando esse contexto, os médios e pequenos integradores de micros foram tomando espaço de fabricantes de marcas conhecidas. Isto porque o usuário final praticamente não comprou nada, ou, quando o fez, optou pelas chamadas white boxes (micros legais sem marca), ou pelo contrabando. (WEBSTER, 1999).

Soma-se a esse cenário o fato de que não havia ainda qualquer definição sobre a continuidade ou não dos incentivos, e o que ocorreria após outubro, data limite para a isenção de IPI. O Congresso Nacional não conseguiu acordar e votar um consenso sobre o assunto, portanto a lei não foi aprovada a tempo. A discussão parlamentar se estenderia, na verdade, até janeiro de 2001, quando seria promulgada a Lei 10.176/01.

Para evitar o término dos incentivos, o governo iniciou a emissão de uma série de medidas provisórias que estendiam paulatinamente a validade da isenção de IPI. Ressaltase que apenas esse benefício fiscal era prorrogado. Essas normas na verdade tratavam de uma série de outras questões fiscais, e em seu bojo era inserido um artigo (desconectado do contexto do restante da norma), que determinava a extensão do artigo $4^{\circ}$ da Lei 8.248/91 (responsável por determinar o prazo do referido incentivo).

Assim, durante mais de um ano a indústria de informática passou a conviver com uma situação de incerteza quanto aos rumos da política. Como as medidas provisórias à época tinham sua validade limitada a 30 dias nos termos da Constituição Federal, não se sabia ao certo até quando seria possível contar com a isenção do IPI (embora possivelmente seja errôneo afirmar que não havia qualquer indicativo do que iria acontecer, uma vez que o governo federal tinha um posicionamento favorável à renovação 
dos incentivos, e esperava-se que esses continuariam a ser prorrogados até uma decisão no Congresso). A tabela abaixo relata o conjunto de normas editadas no período, e o prazo pelo qual prorrogaram a isenção fiscal:

\begin{tabular}{|c|c|c|}
\hline Data & Ato & Prazo previsto de prorrogação \\
\hline Dez/1999 & MPV 2.013-4/99 & Até $1^{\circ}$ de março de 2000 \\
\hline $\operatorname{Jan} / 2000$ & Lei $9.959 / 00$ & Até $1^{\circ}$ de março de 2000 \\
\hline Fev/2000 & MPV 1.991-14 & Até 31 de maio de 2000 \\
\hline Mar/2000 & MPV 1.991-15 & Até 31 de maio de 2000 \\
\hline $\mathrm{Abr} / 2000$ & MPV 1.991-16 & Até 31 de maio de 2000 \\
\hline Mai/2000 & MPV 1.991-17 & Até 31 de agosto de 2000 \\
\hline Jun/2000 & MPV 1.991-18 & Até 31 de agosto de 2000 \\
\hline Jun/2000 & MPV 2.037-19 & Até 31 de agosto de 2000 \\
\hline $\mathrm{Jul} / 2000$ & MPV 2.037-20 & Até 31 de agosto de 2000 \\
\hline Ago/2000 & MPV 2.037-21 & Até 31 de agosto de 2000 \\
\hline Set/2000 & MPV 2.037-22 & Até 31 de novembro de 2000 \\
\hline Out/2000 & MPV 2.037-23 & Até 31 de novembro de 2000 \\
\hline Nov/2000 & MPV 2.037-24 & Até 31 de dezembro de 2000 \\
\hline
\end{tabular}

Retomando os debates parlamentares e as notícias jornalísticas publicadas, percebese que a posição consensual do governo e da maioria dos parlamentares era favorável à continuidade da política. Sendo inviável qualquer possibilidade de retomada da linha desenvolvimentista da década de oitenta, a atual política constituía a única possibilidade de promoção do setor. E, ao mesmo tempo, não se pode afirmar que os incentivos físcais constituíam um grande ataque ao livre comércio, de forma que o conflito entre o liberalismo e o protecionismo não parecia mais fazer sentido. Nesse sentido, o debate ideológico que permeou este tema até o início dos anos noventa encontrava-se em grande parte superado.

Nesse novo cenário o conflito passou a ser travado com os parlamentares da bancada do norte do país, em especial do estado do Amazonas. A política de informática era identificada como conflitante com o esforço de regionalização industrial realizado através da política pública da ZFM.

Acredito encontrar-se fora do âmbito deste trabalho uma explanação mais detalhada sobre a história e os objetivos da política pública que gerou e mantém até hoje a ZFM. 
Basta uma resumida explicação que permita entender os motivos do referido debate. Para compensar as desvantagens de localização da Amazônia, a legislação que criou a ZFM, Decreto-Lei $n^{\circ}$ 288/67 (alterado pelo Decreto-Lei $n^{\circ} 1.435 / 75$ e pela Lei $n^{\circ} 8.387 / 91$ ), definia a área como de livre comércio de importação e exportação, além de aplicar incentivos fiscais especiais. (TAVARES, 2001, p. 6). Os benefícios aplicados à Zona Franca na década de sessenta foram garantidos até 2013 pela Constituição de $1988^{27}$. A ZFM como um todo movimenta um grande volume de recursos financeiros, sendo a maior parte proveniente do setor eletro-eletrônico, e constitui o maior pólo de desenvolvimento industrial daquele estado.

De acordo com a legislação que disciplinava a região, as empresas de informática que lá se instalassem fariam jus a incentivos fiscais muito próximos aos que dispunha a Lei de Informática (sendo o principal a isenção de IPI), tendo também que cumprir com contrapartidas de pesquisa e desenvolvimento e grau de agregação de valor local. Assim, possuindo ambas as políticas uma regulamentação de incentivos semelhante, os parlamentares defensores da Zona Franca viam na política de informática uma concorrência muito forte ao desenvolvimento industrial da região. Se as empresas de informática poderiam receber os mesmos incentivos instalando-se em pólos industriais já consolidados (em especial na região sudeste), não haveria maiores estímulos ou razão no seu deslocamento para a região amazônica.

Um grande interesse, assim, que existe no conflito entre a política de informática e a ZFM encontra-se no fato de não ser um debate balizado por qualquer fundo ideológico, mas uma luta de interesses entre duas políticas públicas que apresentam pontos de contradição e incoerência entre si. Os diferentes parlamentares que defendiam um e outro grupo buscavam atender as necessidades e anseios de suas regiões, buscando com isso atrair e criar incentivos para a instalação de empresas de informática.

A primeira proposta de renovação da Lei de Informática, como mencionado, data de 1996, de autoria do deputado Jair Bolsonaro. O PL 2.514/96 estendia por apenas 5 anos

\footnotetext{
${ }^{27}$ Artigo 40 do Ato das Disposições Constitucionais Transitórias: "É mantida a Zona Franca de Manaus, com suas características de área de livre comércio, de exportação e importação, e de incentivos fiscais, pelo prazo de vinte e cinco anos, a partir da promulgação da Constituição. Parágrafo Único: Somente por lei federal podem ser modificados os critérios que disciplinaram ou venham a disciplinar a aprovação dos projetos na Zona Franca de Manaus".
} 
os benefícios fiscais, ou seja, até o fim de 2002. Por outro lado, a proposta pretendia prorrogar todos os incentivos fiscais da Lei 8.248/91 (incluindo, dessa forma, a capitalização incentivada e a redução do IR), e não apenas a isenção de IPI. O projeto não trouxe grandes debates nem teve relevantes desenvolvimentos até 1999, quando foi apensado ao PL 342, do deputado Júlio Redecker (devido às normas internas da casa o PL 2.514/96 continuou sendo o projeto principal, mas a discussão centrou-se no texto do PL 342/99). O novo projeto estabelecia a prorrogação da isenção até o ano de 2013, conformando assim o prazo ao estabelecido na constituição federal para a ZFM (noto que na justificativa do autor e no voto do relator deputado Júlio Semeghini não é feita qualquer referência a esse ponto. Ambos buscaram legitimar a prorrogação apenas pelos méritos internos da política). É também instituída, pela primeira vez, uma redução gradual do benefício fiscal ao longo dos anos, de forma a "exigir da indústria ganhos de produtividade", nas palavras do relator ${ }^{28}$.

A bancada do estado do Amazonas opôs-se ao novo prazo sugerido, afirmando que a prorrogação trazia prazo duas vezes maior ao previsto pela legislação inicial. Além disso, uma argumentação frequentemente utilizada para justificar a renovação era o risco das empresas de informática migrarem para a ZFM, o que certamente vinha de encontro ao interesse desses parlamentares. Para viabilizar a aprovação do projeto, foi fechado um acordo que envolvia dois pontos: a redução do prazo da prorrogação, que passaria a valer apenas até 2009, e uma alíquota diferenciada para as regiões Norte, Nordeste e CentroOeste, que garantiria uma redução em torno de $1 \%$ no preço final dos produtos dessas regiões ${ }^{29}$.

Outro ponto debatido pelos parlamentares foi a destinação dos recursos de pesquisa e desenvolvimento. Havia uma reclamação de que a quase totalidade desses recursos estaria sendo utilizada apenas nas regiões sul e sudeste, tanto na pesquisa empresarial quanto nos convênios com universidades e instituições de ensino. Considerando que um dos principais objetivos da lei era a capacitação tecnológica e a formação de recursos humanos, os parlamentares dos demais estados passaram a exigir a destinação de parte desses recursos a instituições localizadas fora do eixo tradicional. $\mathrm{O}$ acordo quanto a este

\footnotetext{
${ }^{28}$ Conforme Diário da Câmara dos Deputados, 19.10.1999, p. $49 \_381$.

${ }^{29}$ Conforme Diário da Câmara dos Deputados, 19.10.1999, p. 49_385.
} 
aspecto passou a exigir o direcionamento de $40 \%$ dos recursos em pesquisa e desenvolvimento para as regiões norte, nordeste e centro-oeste.

Em dezembro de 2000 o cenário ganha mais um elemento de complicação, agravando as divergências. O Estado do Amazonas tentava resguardar benefícios para a região de Manaus não apenas através de seus parlamentares no Congresso Nacional, mas também através de uma Ação Direta de Inconstitucionalidade impetrada perante o STF, na qual o Estado atacava as medidas provisórias do governo federal que prorrogavam os incentivos à Lei de Informática. No sexto dia daquele mês o tribunal deferiu a cautelar, suspendendo imediatamente a validade dos benefícios fiscais ${ }^{30}$.

A decisão foi recebida com surpresa e forte preocupação pelo governo federal e pela indústria. Além de toda a reestruturação no sistema de preços que a incidência do IPI iria acarretar, criou-se ainda um forte receio acerca de uma possível cobrança retroativa do imposto. Uma situação com severas repercussões para os empresários localizados fora da região da $\mathrm{ZFM} .^{31}$

Após o período de aproximadamente uma semana discutindo qual seria a melhor solução para o problema criado pelo STF, o governo opta por não editar mais uma medida provisória com a isenção do imposto, o que significaria um conflito com a decisão judicial e possivelmente um impasse institucional com o poder judiciário. Ao invés disso, adota uma solução mais conciliadora: edita o Decreto 3.686/00, na qual reduzia a alíquota do IPI para $2 \%$ para os bens de informática ali relacionados.

Embora a medida solucionasse momentaneamente o impasse, a situação parecia insustentável sem a aprovação da nova legislação pelo Congresso Nacional. O projeto de lei já havia sido aprovado na câmara, e se encontrava no senado federal para discussão. A bancada do Amazonas, entretanto, habilmente conseguiu gerar uma nova controvérsia que emperrava a aprovação da lei. Foi inserido um novo dispositivo no texto do projeto, através do qual o estado da federação que tivesse sido responsável por mais da metade da isenção

\footnotetext{
${ }^{30}$ Ação Direta de Inconstitucionalidade (ADI) no. 2.348. Julgamento em 7 dez. 2000, Relator Min. Marco Aurélio. O acompanhamento do processo pode ser visualizado através da página do STF, em $<$ http://www.stf.jus.br/portal/jurisprudencia/listarJurisprudencia.asp?s1=(ADI\$.SCLA.\%20E\%202348.NUM E.)\%20OU\%20(ADI.ACMS.\%20ADJ2\%202348.ACMS.)\&base=baseAcordaos>. Acesso em 28.4.2008.

${ }^{31}$ Conforme notícia: LEI de Informática: a indústria por um fio. Informática Hoje, n. 509, dez. 2000, pp. 1617.
} 
fiscal do IPI nos dois anos anteriores não poderia receber novos projetos (art. 10). O alvo era obviamente a indústria de informática paulista, numa tentativa de enfraquecer os pólos ali estabelecidos. Para evitar uma disputa que atrasaria ainda mais a aprovação da lei, os demais parlamentares aceitaram a inclusão desse artigo, certos que estavam do veto do presidente Fernando Henrique Cardoso, que realmente assim o fez.

Solucionadas essas e outras controvérsias (uma das maiores sendo a inclusão de monitores e aparelhos celulares no rol de bens incentivados), o projeto é aprovado pelo Congresso Nacional e promulgado em janeiro de 2001 como a Lei 10.176. As novidades e principais pontos desta lei já foram discutidos: ela prorrogava os incentivos relativos ao IPI até o ano de 2009, havendo um aumento gradual da tributação a partir de 2001; as regiões norte, nordeste e centro-oeste receberam um incentivo fiscal maior; e parte dos recursos exigidos de pesquisa e desenvolvimento ( $5 \%$ do faturamento bruto) deveriam ser utilizados em instituições de ensino das mesmas regiões mencionadas, além do $0,5 \%$ que deveria ir para o $\mathrm{FNDCT}^{32}$.

A aprovação da lei não significava o fim das discussões. Até a nova regulamentação e a aprovação dos PPBs das empresas, os incentivos fiscais previstos não beneficiariam de fato as empresas. Para evitar maiores delongas nesse processo, a própria lei estabeleceu que o poder executivo deveria regulamentar o processo de fixação do PPB em até sessenta dias. O decreto que regulamentava a nova legislação, entretanto, só veio no final de abril (Decreto 3.800/01). E as portarias para definição dos processos produtivos e dos requisitos para as instituições de ensino participarem dos projetos de pesquisa envolvendo apenas foram publicadas em junho (Portarias Interministeriais MDIC/MCT 90 e 253, e Portaria MCT 252).

Por fim, havia ainda um ponto pendente, que era a alíquota do IPI. Como mencionado, para contornar a decisão do STF anulando as medidas provisórias anteriores à Lei 10.176/01, o governo federal havia editado decreto reduzindo o imposto a apenas $2 \%$. Esse valor de tributação, entretanto, não era aplicável apenas aos bens de informática com agregação de valor local na produção, mas a todos os bens, incluindo importados. Isso gerava um grave problema, pois significava que a fabricação local tinha pouco ou quase

\footnotetext{
${ }^{32}$ Os chamados fundos setoriais, que serão debatidos no próximo capítulo.
} 
nenhum favorecimento tarifário, gerando um grande medo por parte da indústria da concorrência internacional. Setores do governo, no entanto, acreditavam que esta era uma boa oportunidade para reduzir a tributação e a proteção à indústria, e pretendiam manter o valor cobrado do IPI. (AQUINO, 2001). A situação só seria resolvida ao final de 2001, quando o governo federal assina as primeiras portarias aprovando o PPB solicitado por algumas empresas, e editando o decreto que restaurava as alíquotas do IPI a valores entre $10 \%$ e $15 \%{ }^{33}$.

Tomando o ano de 1999 como o início das discussões mais urgentes sobre a prorrogação da política de informática, foram assim 3 anos até que se tivesse uma posição clara do setor público acerca dos instrumentos de incentivo para o setor. A demora nas tomadas de decisões governamentais é certamente uma marca desse processo de transição, que trouxe prejuízos para a indústria devido à incerteza gerada e a não linearidade e fugacidade das normas (principalmente considerando as diversas medidas provisórias, a decisão do supremo tribunal e o decreto governamental).

Retomo ainda que as grandes divergências não se encontravam no setor privado (onde não havia muitos opositores à política), mas entre grupos de interesses dentro do próprio governo (Ministério da Fazenda e MCT), e entre parlamentares defensores de duas políticas públicas também do governo federal.

\section{$\underline{3.7 \text { O governo Lula da Silva e a segunda renovação da Lei de Informática }}$}

Conforme Campanário et. al., durante os anos do governo Fernando Henrique Cardoso a política econômica foi voltada à abertura econômica, causando profundas mudanças estruturais na indústria ao afetar seu nível de investimento, preços, produção, valor adicionado, margens, emprego, coeficientes de comércio e produtividade. Considerando a necessidade de consolidação do Plano Real e as crises econômicas internacionais ocorridas ao final dos anos noventa, deu-se preponderância aos instrumentos estabilizadores da política econômica. A idéia de política industrial, especialmente se considerada sob uma perspectiva sistêmica e integrada de diversos setores, foi negligenciada ou abandonada. (CAMPANARIO, SILVA E COSTA, 2005).

\footnotetext{
${ }^{33}$ Conforme notícia: A LEI de informática, enfim, sai do papel. Informática Hoje, n. 531, dez/2001, p. 4.
} 
Tentando estabelecer uma tipologia classificatória das diversas políticas públicas voltadas à promoção industrial no Brasil, os autores situam esse período em uma fase que vai de 1989 até 1999:

\begin{abstract}
"Nesta nova fase, seriam empregados instrumentos passivos de política industrial, baseados nos mecanismos de livre mercado, como meios de promover o desenvolvimento industrial. Este modelo, ainda não totalmente superado, se baseia na (re)inserção externa da economia brasileira por meio da abertura comercial, financeira e patrimonial dos setores público e privado, privilegiando as forças de mercado como melhor meio de garantir a estabilidade de preços, a eficiência do setor produtivo industrial e a defesa da concorrência." (CAMPANARIO, SILVA E COSTA, 2005, p. 6).
\end{abstract}

A partir do início do governo Lula da Silva em 2003, o tema da política industrial voltou à pauta. Já no PPA apresentado pelo governo ficou clara essa intenção de voltar à promoção setorial e estabelecer um marco regulatório e de incentivos à indústria. Conforme a exposição da orientação estratégica do plano, a política industrial a ser concebida atuaria em dois níveis: horizontal e vertical. As políticas horizontais seriam concentradas na redução do custo Brasil e na busca de isonomia de tratamento das exportações e importações brasileiras de bens e serviços. Considerando a natureza dessas medidas, identifica-se então um elemento de continuidade e não ruptura com as idéias macroeconômicas seguidas pelo governo anterior. O governo reconhece, entretanto, a insuficiência dessas medidas, ao afirmar que elas não seriam suficientes para aumentar a competitividade e diversificar a produção brasileira. É afirmada a importância de setores estratégicos, e a necessidade de definir critérios de escolha e políticas prioritárias para se atingir os objetivos de elevar o investimento em indústrias exportadoras, que substituam importações e com elevado nível de utilização de capacidade. Entre esses critérios, destacam-se o desempenho, a temporalidade e a transparência das políticas verticais. (MINISTÉRIO DO PLANEJAMENTO, ORÇAMENTO E GESTÃO, s.d., p. 9).

Ao final de 2003 o governo lança as Diretrizes da PITCE. O documento explicita as estratégias e objetivos pretendidos com a retomada de uma nova política industrial. $\mathrm{O}$ documento apresenta especial destaque nos temas de inovação, pesquisa e desenvolvimento e setores intensivos em tecnologia. É detectada a baixa contribuição desses setores para a pauta de exportações brasileiras, e a importância econômica e social em desenvolvê-los. A política teria assim por objetivo estimular a capacidade inovadora das empresas, preocupando-se com sua competitividade internacional e inserção no 
mercado externo. Nesse contexto são eleitos 4 setores considerados estratégicos, sendo dois deles pertencentes ao complexo de informática (software e semicondutores).

À luz dessa retomada das discussões sobre a instituição de uma política industrial no Brasil, o MCT promove, ao final do ano de 2003, o I Seminário Resultados da Lei de Informática. Reunindo empresários, profissionais, professores e pesquisadores atuantes em empresas beneficiárias dos incentivos da Lei, e em instituições de ensino e pesquisa que receberam recursos da contrapartida da Lei, bem como representantes dos órgãos da administração pública, o seminário teve por objetivo discutir a Lei de Informática e o estímulo a investimentos em pesquisa, desenvolvimento e produção. (SEPIN, 2004).

O seminário contou com apresentações de representantes de 28 empresas beneficiadas, além de universidades, institutos de pesquisas e dos programas prioritários do MCT financiados pela política. O tom geral era amplamente favorável e otimista com os resultados da lei. A palestra de abertura proferida pelo então secretário executivo do CATI, Arthur Pereira Nunes, que apresentou extensos dados sobre o crescimento do setor sob a égide da política, mão-de-obra empregada, os investimentos em pesquisa e desenvolvimento e os programas públicos financiados. Apresentações de pesquisadores davam a dimensão da importância dos recursos para seus respectivos institutos de pesquisa, como apresentado por Campanário em nome do Instituto de Pesquisas Tecnológicas - IPT da USP ${ }^{34}$.

Considerando esse cenário e o ambiente propício para decisões políticas favoráveis ao desenvolvimento industrial, era de se esperar que a segunda renovação da Lei de Informática, a Lei 11.077/04, fosse fruto desse momento, uma decisão razoavelmente consciente e deliberada acerca de uma política que, após uma avaliação criteriosa, foi considerada benéfica e promotora de efeitos favoráveis para a indústria. A PITCE, o debate promovido pelo MCT, todos esses elementos de alguma forma apontam para um processo de legitimação política de retomada dos incentivos fiscais da Lei de Informática, como se tivessem sido previamente planejados para fornecer subsídios para a renovação que estaria por vir.

\footnotetext{
${ }^{34}$ Disponível em <http://www.mct.gov.br/index.php/content/view/33541.html>. Acesso em 7.5.2008.
} 
Entretanto, a pesquisa e resgate do processo de geração da Lei 11.077/04 revelam que essa hipótese, em grande parte, é falsa. Não pretendo com isso afirmar que os elementos acima levantados tenham sido completamente irrelevantes ou desconexos em relação à nova legislação aprovada. Apenas não foram os aspectos preponderantes. A leitura dos debates parlamentares na Câmara dos Deputados demonstra que um terceiro fator, frequentemente citado neste capítulo, teria mais uma vez influído: a disputa de incentivos com a ZFM.

A história da segunda renovação da Lei de Informática começa com a reforma tributária proposta pelo novo governo Lula da Silva no início de seu mandato. Logo que assumiu o governo, o presidente encaminhou ao congresso o seu projeto (PEC 41/03), em moldes muito próximos àquele já anteriormente enviado pelo seu antecessor e debatido pelos parlamentares (PEC 175/95). O objetivo da reforma propalado pelo governo era a "racionalização e simplificação dos tributos, e promover a justiça social, desonerando as pessoas de menor renda e ampliando a progressividade do sistema" ${ }^{35}$.

A proposta foi objeto de grande debate antes e depois de sua aprovação. A despeito de seus objetivos, tributaristas afirmavam que a PEC, se aprovada nos termos propostos pelo governo, traria novas irracionalidades ao sistema tributário nacional e aumentaria a carga tributária. Devido ao alto grau das discordâncias, diversas alterações tiveram que ser acordadas na câmara e no senado que permitissem a aprovação da mudança constitucional. Os principais pontos da proposta do governo eram a progressividade do ITR, do ITCMD e do ITBI, a regulamentação do ICMS por normas de caráter nacional (lei complementar e regulamento por colegiado de estados) e harmonização das legislações e alíquotas, e a prorrogação da CPMF. Em sua redação original, a PEC 41/03 não fazia qualquer referência sobre a Lei de Informática ou a isenção de IPI. Esse tema, aliás, não tinha qualquer relação ou motivo aparente para ser debatido conjuntamente com essa reforma tributária.

No curso dos debates no congresso, deputados ligados ao estado do Amazonas identificaram a reforma como uma oportunidade para ampliar os benefícios da ZFM que, de acordo com a redação original da Constituição, se encerraria em 2013. Haja vista toda a dificuldade e polêmica para aprovação da proposta do governo, esses parlamentares

\footnotetext{
${ }^{35}$ Exposição de motivos da PEC 41/03 - E.M.I. no. 84/MF/C.Civil. Brasília, 2003.
} 
compreenderam a importância de seu apoio, e, em um processo de barganha, utilizaram como moeda política de troca a prorrogação da área de livre comércio. Assim, foram apresentadas propostas de emendas à PEC 41/03 nesse sentido, com argumentações semelhantes, afirmando que "seja no comércio, na indústria, na agropecuária, ou mesmo na área social e ambiental, a Zona Franca vem irradiando notáveis e indispensáveis benefícios para toda Amazônia Ocidental"36, e ainda "é oportuno assegurar a continuidade do modelo, de vez que caminhando para o prazo final de 2013, a atração de novos empreendimentos começa a se tornar difícil em virtude do tempo necessário para a maturação de investimentos" ${ }^{37}$.

Para inclusão da reivindicação dos deputados amazonenses na emenda constitucional foi firmado um acordo com o governo e os demais parlamentares. E um dos elementos dessa composição era que a prorrogação da ZFM seria compensada com uma renovação da Lei de Informática também por mais dez anos. Este ponto foi muito bem exposto pelo relator da comissão de desenvolvimento econômico, industrial e comercial da câmara dos deputados que analisou o projeto de alteração da Lei de Informática, Léo Alcântara:

\begin{abstract}
"a principal motivação econômica por trás da determinação da emenda constitucional $\mathrm{n}^{\circ} 42$, de 19 de dezembro de 2003 (Art $5^{\circ}$ ), relativa à reforma tributária, diz respeito à extensão, procedida no Art. $3^{\circ}$ da mesma Emenda, dos benefícios fiscais gozados pela Zona Franca de Manaus de 2013 para 2023. Postergando tais incentivos regionais, sem que houvesse qualquer alteração do cronograma de concessão de incentivos fiscais no setor de tecnologias de informação previstos para o resto do país, muito possivelmente implicaria em forte movimento de relocalização industrial, nesse setor, das outras áreas do país para a Zona Franca de Manaus. As distorções econômicas que seriam geradas como conseqüência de tal movimento poderiam ser, de fato, substanciais, inclusive com impactos negativos sobre a competitividade do setor no país" ${ }^{38}$.
\end{abstract}

Localizei poucas referências esparsas sobre esse acerto que trouxe os parlamentares nortistas para a sustentação da PEC 41/03, mas sua existência parecer ser de fácil comprovação. Ao apresentar seu parecer ao plenário, o deputado Virgílio Guimarães fez uma indireta menção ao assunto "apesar da demora, os colegas [parlamentares do

\footnotetext{
${ }^{36}$ Conforme Justificação da emenda aditiva 5 à PEC 41/03, da deputada Vanessa Graziotin.

${ }^{37}$ Justificação da emenda aditiva 312 à PEC 41/03, dos deputados Lupércio Ramos, Átila Lins, Carlos Souza, Francisco Garcia, Humberto Michiles, Pauderney Avelino, Silas Câmara e Vanessa Graziotin. Cito as principais emendas à PEC 41/03 que buscavam prorrogar a ZFM, juntamente com a respectiva autoria: Emenda 5 (Vanessa Grazziotin), 14 (Pauderney Avelino), 153 (Silas Câmara), 222 (Lupércio Ramos), 312 e 343 (Humberto Michiles).

${ }^{38}$ Parecer do relator, disponível em <http://www2.camara.gov.br/proposicoes/loadFrame.html?link=http:// www.camara.gov.br/internet/sileg/prop_lista.asp?fMode $=1 \&$ btnPesquisar $=$ OK\&Ano $=2004 \&$ Numero $=3015$ \&sigla $=\mathrm{PL}>$. Acesso em 28.5.2008.
} 
Amazonas] foram compreensivos e participaram das negociações, como já havia ocorrido na Comissão no caso da prorrogação dos incentivos à Zona Franca, o que trouxe desenvolvimento às áreas de informática e microeletrônica" ${ }^{\circledR 3}$. Mais explicitamente, nos debates do projeto que resultaram na lei 11.077/04 o deputado Júlio Semeghini mencionou:

\begin{abstract}
"Estamos cumprindo grande acordo que esta Casa fez, com a assinatura de todos os Líderes, de prorrogar por 10 anos, de forma justa, o prazo de vigência dos incentivos fiscais concedidos à Zona Franca de Manaus. Naquele dia, assumimos nesta Casa o compromisso de prorrogar também por 10 anos os benefícios de toda a indústria de informática e de telecomunicações no resto do País, de forma a assegurar a competitividade das indústrias em todos os Estados brasileiros. O Poder Executivo cumpriu o acordo e mandou o projeto para a Câmara". (grifos nossos). ${ }^{40}$
\end{abstract}

No mesmo sentido o deputado Beto Albuquerque

\begin{abstract}
"Este é um compromisso do Governo de dar ao setor de informática, no que se refere a prazo, o mesmo tratamento conferido à Zona Franca de Manaus na reforma tributária. Foi uma equiparação de direitos, apostando que ambos os segmentos, a Zona Franca de Manaus e o setor de informática, juntos, com mais prazo e iguais benefícios, sem dúvida, impulsionarão cada vez mais o desenvolvimento econômico do nosso País". (grifos nossos). ${ }^{41}$
\end{abstract}

Assim, com base nesse pacto, a emenda constitucional 42/03 inseriu novo artigo no ato das disposições constitucionais transitórias (ADCT) (artigo 92), no qual dava à ZFM mais dez anos de vigência, e determinou ao Poder Executivo encaminhar projeto de lei ao Congresso Nacional, sob o regime de urgência constitucional, para disciplinar os benefícios fiscais para a capacitação do setor de tecnologia da informação, que vigerão até 2019 nas mesmas condições então em vigor (artigo 5).

Em março de 2004 o governo remete ao Congresso Nacional o projeto de lei 3.015, cumprindo o disposto na emenda constitucional. O texto inicial não se afastava da legislação anteriormente em vigor (Lei 10.176/01), estabelecendo uma redução gradual dos benefícios, a exigência de contrapartida em pesquisa e desenvolvimento, e incentivos maiores para as empresas localizadas nas regiões norte, nordeste e centro-oeste. O projeto incorporava uma alteração efetuada na legislação em 2003, através da Lei 10.664/03, que

\footnotetext{
39 Parecer proferido em plenário, disponível em <http://www.camara.gov.br/sileg/ MostrarIntegra.asp?CodTeor=160879>. Acesso em 28.5.2008.

40 Parecer proferido em plenário, disponível em <http://www2.camara.gov.br/proposicoes/ loadFrame.html?link=http://www.camara.gov.br/internet/sileg/prop_lista.asp? fMode=1\&btnPesquisar=OK\& Ano $=2004 \&$ Numero $=3015 \&$ sigla $=$ PL $>$. Acesso em 28.5.2008.

41 Parecer proferido em plenário, disponível em <http://www2.camara.gov.br/proposicoes/ loadFrame.html?link=http://www.camara.gov.br/internet/sileg/prop_lista.asp? fMode=1\&btnPesquisar=OK\& $A n o=2004 \&$ Numero $=3015 \&$ sigla $=P L>$. Acesso em 28.5.2008.
} 
dava tratamento diferenciado para unidades de processamento digitais de pequena capacidade baseadas em microprocessadores.

Uma vez que a emenda constitucional já havia determinado o novo prazo dos incentivos, o debate no Congresso Nacional para aprovação do PL 3.015/04 versou muito pouco ou nada sobre a conveniência da nova legislação. A discussão ateve-se, assim, a questões pontuais da política, alguns problemas a serem solucionados ou melhorias sugeridas. Cito abaixo alguns desses pontos:

1. Alteração da base de cálculo dos investimentos em pesquisa e desenvolvimento (apenas os produtos incentivados, e não todo o faturamento da empresa, conforme a lei anterior).

2. O Senado apresentou emenda ao projeto sobre o tema das compras governamentais. Propôs a utilização da modalidade pregão (mais simplificada e célere) nas compras públicas de bens de informática, e especificou mais detalhadamente as condições nas quais as empresas locais beneficiadas seriam preferidas em procedimentos licitatórios.

3. A inclusão, nos benefícios fiscais, de determinados bens ou partes, como monitores de vídeo, aparelhos telefônicos que incorporem tecnologia digital, e discos rígidos e ópticos (estes sob a alegação de que enfrentavam forte concorrência do contrabando de produtos importados).

4. Um ponto muito controverso foi a anistia ou parcelamento de débitos atrasados de recursos de pesquisa e desenvolvimento, que não haviam sido gastos pelas empresas nos percentuais exigidos pela lei. Os fabricantes realizaram grande pressão política para serem anistiados desses débitos, ou que se chegasse a uma solução intermediária que não exigisse sua exclusão dos benefícios da lei (o que certamente representaria o fim da empresa). De outro lado a burocracia governamental atrelada a interesses fiscais não concordava com a anistia.

A Lei 11.077 é sancionada pelo presidente no final do ano de 2004. Os incentivos mais uma vez são escalonados para ter um término gradual (fasing-out), iniciando com uma leve redução em 2006 até uma alíquota mais alta de IPI em 2016 (30\%), que valerá até o final 2019. Os percentuais de investimentos em pesquisa seguem a mesma lógica. 
Um ponto relevante nesta nova versão da legislação foi a retomada do incentivo específico ao desenvolvimento local de produtos. Além da exigência de contrapartida em atividades de pesquisa e desenvolvimento, a Lei 11.077/04 estabeleceu que produtos e bens de informática desenvolvidos no país teriam uma maior redução na carga de IPI do que aqueles que fossem simplesmente fabricados localmente conforme o PPB. A diferença da carga tributária incidente entre os dois grupos não chega a ser de grande monta. $\mathrm{O}$ valor da redução de IPI é apenas 15\% maior para os produtos desenvolvidos no país (95\%) do que para os demais (80\%) até 2014, e a partir de 2016 ambos terão o mesmo benefício de $70 \%$ a menos no valor do imposto.

Ainda assim, a inovação trazida pela nova lei traz de volta uma abordagem que tinha sido completamente abandonada desde a extinção da reserva de mercado. O desenvolvimento interno de tecnologia não foi parâmetro para concessão de benefícios fiscais durante toda a década de noventa nas edições anteriores da lei. Somado ao fato de que a legislação não exigia quaisquer metas ou objetivos concretos para as atividades de pesquisa e desenvolvimento, é razoável argumentar que o desenvolvimento interno de novos produtos não foi uma preocupação central da política de informática, ao menos até a Lei $11.077 / 04$.

Seria enganoso, contudo, relacionar essa nova estrutura de incentivos a uma retomada do esforço tecnológico nacionalista, especialmente nos moldes imaginados pelos "guerrilheiros tecnológicos". Isto porque o valor irrisório do benefício fiscal está longe de ser suficiente para uma estratégia de estufa ou barreira tarifária que compensasse o custo e esforço de empresários locais abrirem mão da importação de tecnologia externa e lançarem-se ao risco do desenvolvimento local.

Faz mais sentido, assim, entender essa alteração da lei como mais uma forma de tentar atrair recursos e centros de pesquisa de empresas estrangeiras que atuem no Brasil e que, por força dos investimentos exigidos, já realizem aqui algum esforço tecnológico. Ao conceder um privilégio superior aos produtos desenvolvidos internamente, a lei tenta incentivar tais empresas a inserir o país em seu circuito relevante e estratégico de 
pesquisas, desenvolvendo produtos que serão comercializados no mercado interno e possivelmente no exterior ${ }^{42}$.

A abordagem proposta apresenta alguns problemas, especialmente considerando que as atividades de pesquisa e desenvolvimento nas empresas de tecnologia da informação encontram-se atualmente fragmentadas e dispersas nas mãos de diferentes atores e localidades, entre pesquisadores internos, contratados e parcelas terceirizadas do trabalho em um regime próximo à empreitada. Essas questões serão destacadas no próximo capítulo, quando discutirei a estratégia de pesquisa da política.

Outro ponto importante a destacar na lei é a obrigação estabelecida ao poder executivo de apresentar relatórios bianuais de avaliação os incentivos da lei e de sua aplicação no período. Conforme mencionado pelo relator da comissão de desenvolvimento econômico, indústria e comércio da câmara dos deputados, Léo Alcântara,

\begin{abstract}
"Um dos maiores problemas das políticas setoriais brasileiras baseadas em incentivos fiscais, além de outros, é a falta de mecanismos de avaliação de desempenho. O Legislativo e a Sociedade em geral, em geral, tendem a se ver privados de informações consistentes sobre o resultado de tais incentivos. Afinal de contas, o que o Estado deixa de receber em receita tributária tem um custo de oportunidade no que se deixa de gastar em setores cruciais como saúde e educação. Saber o efeito do uso alternativo desses recursos pelas empresas beneficiadas se torna, portanto de suma importância". ${ }^{43}$
\end{abstract}

Por fim, a última parte da história da política de informática até o presente foi a regulamentação da nova lei, que levou mais de 20 meses para sua edição (ocorrendo em setembro de 2006). Alguns assuntos foram objeto de pesada negociação entre governo e empresas, especialmente a questão do pagamento, parcelamento e multa dos débitos atrasados de pesquisa e desenvolvimento. Até a aprovação da nova lei, diversas empresas deixaram de cumprir o percentual exigido nessas atividades, ou tiveram suas contas rejeitadas pelo ministério da ciência e tecnologia. A regularização dos débitos dessas empresas, permitindo a elas continuar usufruindo dos benefícios fiscais, era um grande impasse e uma questão central a ser resolvida.

42 Nesse sentido declarou o então coordenador da área de tecnologia da informação do MCT, Roberto Martins. Disponível em <http://www.inovacao.unicamp.br/report/news-leideinformatica.shtml $>$. Acesso em 23.6.2008.

43 Parecer do relator, disponível em <http:/www2.camara.gov.br/proposicoes/ loadFrame.html?link=http://www.camara.gov.br/internet/sileg/prop_lista.asp?fMode=1\&btnPesquisar=OK\& Ano $=2004 \&$ Numero $=3015 \&$ sigla $=$ PL $>$. Acesso em 28.5.2008. 
O decreto que regulamentou a nova lei (5.906/2006) também trouxe outras alterações, como uma tentativa de simplificar os procedimentos para obtenção dos benefícios, considerando que uma das maiores reclamações das empresas era o tempo gasto pelo MCT para sua aprovação, e um detalhamento minucioso das atividades de pesquisa e desenvolvimento aceitas pelo governo.

Com isso se encerram as principais reformas e renovações da Lei de Informática realizadas até o presente. Como meu objetivo era a análise e compreensão de seus elementos normativos e institucionais (à luz dos fatores políticos e econômicos que os determinaram), dou por concluída a tarefa de reconstrução histórica da política em sua fase após a abertura econômica do setor. Resta, contudo, entender quais foram seus resultados efetivos e problemas, o que passo a analisar nas próximas seções.

\subsection{A indústria de informática no mundo e a abertura de mercado no Brasil}

Destacar e analisar os efeitos da política brasileira de informática nos anos noventa é uma tarefa que apresenta um desafio próprio. Fora toda a dificuldade envolvida na avaliação de qualquer política pública setorial, através de seus indicadores, dados e informações relevantes, há ainda outros problemas específicos neste caso. O período no qual foi implantada a política coincidiu com dois outros momentos relevantes para a indústria. Em primeiro lugar a abertura de mercado, já descrita aqui, que embora não tenha se limitado à informática, teve repercussões muito fortes nesse setor. Além disso, o final do século passado e início do presente foi uma época com especiais características no mercado global de equipamentos de informática. $\mathrm{O}$ vigoroso crescimento seguido da crise das empresas de alta tecnologia no início da década influenciou fortemente os resultados e a dinâmica desse setor no mundo todo, com evidentes reflexos no cenário brasileiro. Por essa razão, torna-se difícil separar esses dois elementos da política que começa com a Lei $8.248 / 91$. Para tentar minimizar esse problema, irei, em breves linhas, apresentar um resumo sobre esses temas.

A década de noventa representou para a indústria de informática mundial uma continuação, em termos gerais, de duas tendências que já a acompanhavam desde o seu surgimento: um crescimento vertiginoso, acima da média das economias nacionais e dos 
demais setores econômicos, e a alta concentração do desenvolvimento e produção em países e grupos econômicos que dominam essa tecnologia.

Pode-se afirmar que a indústria de informática viveu uma era de prosperidade e de grande expansão durante toda a década de noventa. O setor de Tecnologia da Informação e Comunicação - TIC cresceu a uma taxa média anual de 7\% de 1992 a 1997, vendo seu mercado global erguer-se de um valor total de 1,3 trilhões de dólares para 1,8 trilhões. A maior parte desse crescimento deveu-se aos Estados Unidos, que representavam cerca de $36 \%$ desse mercado, seguidos do Japão e dos países não membros da OCDE (dentre eles o Brasil). A maior parte dos gastos referia-se ao setor de telecomunicações, que respondeu por mais da metade de todo o crescimento das TIC no período. A intensidade das TIC (calculada através dos gastos como uma proporção do PIB) também cresceu consideravelmente no período, a uma taxa média de 2,5\% nos países da OCDE. (OCDE, 2000, pp. 32-34). ${ }^{44}$

O comércio desses produtos e equipamentos representava em 1990 cerca de 6,4\% do total de bens comercializados mundialmente. Em 1998 esse percentual sobe para 10,4\%, demonstrando assim um crescimento da importância relativa e uma maior disseminação dos equipamentos e produtos de alta tecnologia, especialmente nas empresas e populações de mais alta renda. Também aqui o setor de telecomunicações teve papel importante, com suas exportações e importações tendo mais do que triplicado no período. O segmento de equipamentos de computação, todavia, representava a maior fatia desse comércio, com cerca de 45\% das exportações dos países da OCDE. (OCDE, 2000, p. 26).

Todo esse setor, à época, encontrava-se absolutamente concentrado nos países da OCDE. Os países do bloco respondiam por mais de $80 \%$ dos equipamentos de TIC, com uma concentração ainda maior no setor de equipamentos de comunicação. Ainda assim, negligenciando as disparidades existentes entre os demais países, pode-se afirmar que parcela significativa dessas economias também foi afetada e vivenciou um enorme crescimento do comércio e utilização da informática. As 20 maiores economias de países não-membros da OCDE alcançaram um mercado de 170 bilhões de dólares em 1997, com uma espetacular taxa de crescimento anual de 15,5\% desde 1992, o que é superior ao dobro

\footnotetext{
${ }^{44}$ Neste estudo da OCDE o setor de TIC é entendido como composto pela indústria de hardware, software e serviços para TI e telecomunicações.
} 
da média da OCDE. (OCDE, 2000, p. 35). O gráfico abaixo, retirado do referido estudo da organização, apresenta os números de alguns desses países. Ressalto a liderança do Brasil no setor, à frente da China, com um crescimento anual médio acima de $20 \%$, um número extremamente elevado qualquer que seja o cenário considerado.

\section{MERCADO DE ICT ENTRE PAÍSES NÃO-MEMBROS DA OCDE}

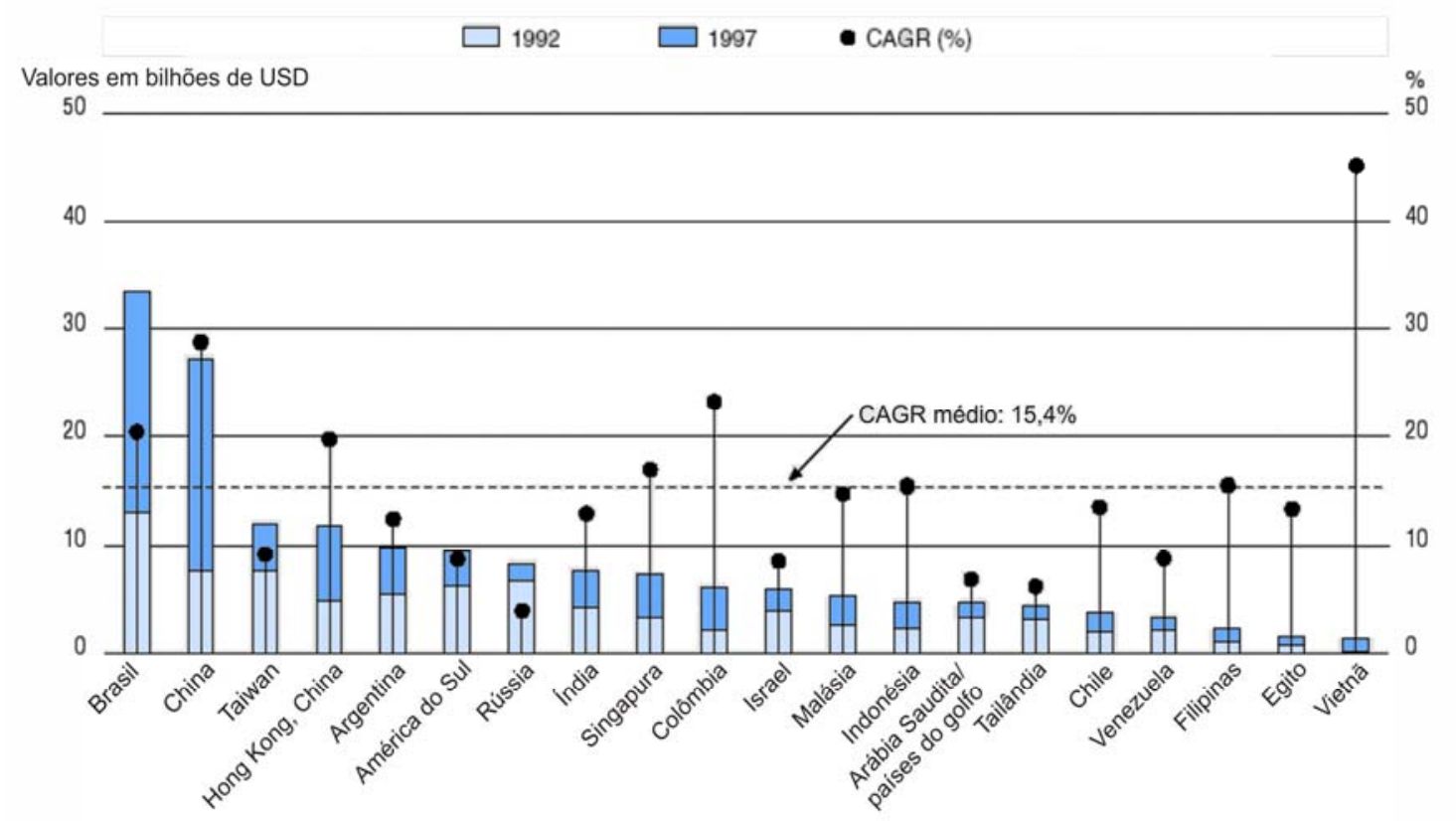

Valores em bilhões de dólares norte-americanos

CAGR(\%): compound annual growth rate (taxa composta de crescimento anual)

Fonte: OECD, 2000, p. 37. Noto que para o caso brasileiro esses dados parecem incoerentes com alguns indicadores internos que apresentarei adiante, possivelmente por diferenças metodológicas. A discrepância, entretanto, não chega a prejudicar os argumentos apresentados.

Considerando apenas o mercado de equipamentos (hardware), recorte mais próximo ao deste estudo, os dados apenas confirmam a tendência de crescimento. $\mathrm{O}$ crescimento anual médio desse segmento nos países da OCDE é de 7,3\% no período 19921997. O dado interessante é o crescimento e consolidação da importância adquirida pelos pequenos computadores pessoais, que passaram a representar $49 \%$ do mercado total de hardware nos mencionados países. As principais explicações para esse fenômeno é a disseminação profunda desses equipamentos nos países da OCDE, que foi permitida pelo aumento da demanda por computadores nas empresas, escolas e casas, conjugada com uma acentuada queda nos preços desses produtos, fruto do avanço tecnológico dos semicondutores e outros componentes e da guerra de preços entre os fabricantes. (OCDE, 2000, p. 60-63). 
O ciclo virtuoso de crescimento foi repentinamente interrompido pela crise no mercado financeiro internacional envolvendo as empresas de alta tecnologia, especialmente aquelas relacionadas à internet (a "crise das ponto-com"). Essa foi a primeira grande crise estrutural pela qual passaram as empresas de informática, com diminuição real do valor de suas vendas.

A crise iniciou-se no ano 2000, mas seus efeitos realmente se materializaram em maior gravidade no ano seguinte. Algumas hipóteses e explicações foram a partir de então elaboradas para explicar o que havia acontecido com um dos setores econômicos que até então havia apresentado taxas de crescimento sustentavelmente altas. Podem ser citadas como causas a explicar parcialmente o problema: o investimento excessivo das firmas, especialmente em capacidade de telecomunicações, esperando uma demanda por serviços que não se realizou; um ajuste nos preços das ações e valores mobiliários das empresas (o estouro da bolha), o que reflete uma crise de confiança e nas expectativas de sucesso e retorno financeiro; a saturação de mercados relevantes para essas empresas, como o de computadores pessoais nos Estados Unidos e o de telefonia celular na Europa; métodos de produção mais eficientes que passaram a demandar menores estoques; e a guerra de preços entre as empresas quando a crise deflagrou e ocorreu o "estouro da bolha". (OCDE, 2002, p. 25).

Em 2002 o setor iniciou uma reação contra o cenário de crise, apresentando já taxas de crescimento maiores em 2003 (2,2\% para os países da OCDE) e 2004 (previsão de 3,4\% à época). As firmas, especialmente as de maior porte, retomaram seus investimentos, havendo uma concomitante volta do consumo. A recuperação, entretanto, não ocorreu em igual intensidade nos diversos setores e países nos quais opera a indústria, causando uma recomposição no quadro e mapa de atividades. Os setores de consumo e negócios (computadores pessoais, banda larga e aparelhos de telefonia celular) apresentaram sólido crescimento mais acelerado, em detrimento de bens de investimento, como a infraestrutura em telecomunicações, que sentiriam por mais tempo os efeitos do superinvestimento ${ }^{45}$.

${ }^{45}$ Uma adequada descrição dessa retomada é feita em OCDE, 2004. 
No que tange aos impactos e repercussões da abertura de mercado do início dos anos noventa no Brasil, estes foram bem estudados e analisados, até mesmo porque foram sentidos por quase todos os setores econômicos brasileiros, e não apenas pela indústria de informática. Conforme Baumann (1999, p. 18), os anos noventa são considerados a "década das reformas". Embora algumas ações iniciais tenham ocorrido no final da década de oitenta, claramente as etapas mais significativas do processo somente começaram a ser cumpridas a partir de 1990. No final dessa década o Brasil surge como uma economia com um grau expressivo de abertura ao comércio de bens de capital, e simultânea redução da função do Estado como produtor direto.

Baptista tenta compreender as alterações ocorridas na estrutura empresarial brasileira tomando por base inicialmente a forma pela qual o cálculo empresarial foi afetado. Segundo a autora, em trabalho que posteriormente foi complementado com Cassiolato, são principalmente duas as repercussões no ambiente de negócios. Em primeiro lugar, o espaço de mercado a partir do qual os empresários passaram a formular suas estratégias passou a ser o mercado internacional e não o nacional, anteriormente protegido. Em outras palavras, a indústria brasileira passa a sofrer a concorrência direta das importações. Além disso, as restrições e regras da reserva de mercado limitavam consideravelmente o conjunto de estratégias disponíveis para cada ator. Com a abertura, diversos elementos que antes eram tomados como parâmetros inescapáveis do processo produtivo converteram-se em variáveis de decisão, possibilitando aos empresários a escolha da melhor alternativa. Podem ser destacados: a separação entre decisões de produção e comercialização, uma vez que a possibilidade de aquisição de peças e componentes no mercado externo abriu uma alternativa à produção local; maior liberdade nas decisões de fabricação ou aquisição de partes e insumos (“decisões de make-or-buy”); e incremento no leque de opções tecnológicas, tanto da fonte e tipo da tecnologia quanto da estrutura contratual a ser utilizada para sua aquisição. (BAPTISTA, 1997).

A autora destaca, entretanto, a existência de um paradoxo entre, de um lado, o aumento da autonomia e do número de estratégias disponíveis e, de outro, uma forte semelhança entre as opções seguidas pelos diversos atores, basicamente a escolha de parceiros ou fornecedores externos. (BAPTISTA, 1997). 
Com base nesse diagnóstico pode-se compreender melhor as alterações causadas na indústria de informática pelas medidas liberalizantes do início da década de noventa. Baptista distingue quatro diferentes efeitos profundos na estrutura industrial desse setor. A tabela abaixo, com alguns dados apresentados sobre a indústria no período, ilustra e corrobora algumas de suas afirmações.

INDICADORES DA INDÚSTRIA DE INFORMÁTICA(1) (1986/1990-1991/1995)

\begin{tabular}{|c|c|c|}
\hline INDICADORES & $1986 / 1990$ & 1991/1995 \\
\hline $\begin{array}{l}\text { FATURAMENTO BRUTO: } \\
\text { - TAXA ANUAL DE CRESCIMENTO (\%) }\end{array}$ & 16,9 & 12,4 \\
\hline $\begin{array}{l}\text { INVESTIMENTOS TOTAIS: } \\
\text { - } \quad \text { MÉDIA ANUAL (US\$ milhões) } \\
\text { - } \quad \text { INVESTIMENTOS/FATURAMENTO (\% médio) }\end{array}$ & $\begin{array}{c}1.283,9 \\
30,7\end{array}$ & $\begin{array}{c}471,8 \\
6,8\end{array}$ \\
\hline $\begin{array}{l}\text { DISPÊNDIOS EM P\&D: } \\
\text { - } \quad \text { MÉDIA ANUAL (US\$ milhões) } \\
\text { - } \quad \text { DISPÊNDIOS/FATURAMENTO (\% médio) }\end{array}$ & $\begin{array}{c}259,3 \\
5,1\end{array}$ & $\begin{array}{c}270,9 \\
3,8\end{array}$ \\
\hline $\begin{array}{l}\text { COMÉRCIO EXTERIOR DAS EMPRESAS: (2) } \\
\text { - } \quad \text { IMPORTAÇÕES/FATURAMENTO (\% médio) } \\
\text { • } \quad \text { EXPORTAÇÕES/FATURAMENTO (\% médio) }\end{array}$ & $\begin{array}{c}11,1 \\
6,5\end{array}$ & $\begin{array}{c}19,9 \\
3,3\end{array}$ \\
\hline $\begin{array}{l}\text { (Fonte: Baptista, 1997) } \\
\text { (1) Conceito amplo de indústria de informática: segn } \\
\text { teleinformática, microeletrônica, automação industrial, in } \\
\text { computador. } \\
\text { (2) Os dados referentes ao período 1986-1990 referem } \\
\text { processamento de dados. }\end{array}$ & ntação & program \\
\hline
\end{tabular}

A primeira grande modificação foi na estrutura produtiva da indústria. O setor de informática experimentou uma redução expressiva nos investimentos totais. Este fenômeno parece estar associado a três fatores:

“(i) à entrada de novas empresas via aquisição ou conversão de joint-ventures
(majoritariamente nacionais) em subsidiárias integrais de empresas estrangeiras;
(ii) à redução nas taxas de crescimento da produção doméstica, seja em função
da desaceleração do crescimento da demanda, seja como decorrência da
substituição de parte desta demanda por importações; (iii) à queda da relação
capital/produto, verificada em função do movimento de desverticalização e
outsourcing generalizado que vem sendo observado nesta indústria, o que
implica a realização de um número muito menor de atividades produtivas
internamente à empresa.” (BAPTISTA, 1997).

No âmbito do comércio entre empresas, o fim do índice de nacionalização utilizado pela política anterior alterou as estratégias empresariais quanto à aquisição de partes e componentes, que passaram a fornecedores internacionais, tendência que ganhou força a partir da apreciação da moeda brasileira em 1994. Embora tenha havido um aumento das 
exportações no período, este não conseguiu compensar a tendência de incremento das importações. (BAPTISTA, 1997).

A questão do déficit comercial agudo é especialmente relevante no caso da indústria de informática não apenas pelo peso acarretado na balança comercial, mas também por evidenciar a desagregação das redes de fornecedores internos e a redução do leque de produção local. O caso sintomático é o da indústria de componentes, que sofreu forte crise a partir da abertura de mercado.

O terceiro efeito foi uma alteração na composição patrimonial da indústria, gerando uma desnacionalização de seu capital, uma reversão da tendência que havia sido determinada pela reserva de mercado. Conforme Baptista, esse processo teve duas fases. Num primeiro momento (1990-1993) ocorreram os acordos de licenciamento de tecnologia e distribuição, além da formação de joint-ventures, tema especialmente relevante do período de transição da política. A segunda fase ocorrida após esse período caracterizou-se pela dissolução desses acordos, na medida em que as empresas nacionais foram sendo paulatinamente absorvidas pelo capital estrangeiro. (BAPTISTA, 1997).

Também as capacidades tecnológica da indústria revelam um alto revés desse processo de reestruturação ocorrido com a abertura de mercado, com a destruição ou não renovação das capacidades locais e recursos humanos qualificados disponíveis, duas das grandes conquistas da política anterior. Os gastos efetuados em pesquisa e desenvolvimento sofreram uma queda expressiva como porcentagem do faturamento, interrompendo uma tendência nítida de crescimento até 1989. Adicionalmente, esses gastos apresentaram uma mudança substancial em sua orientação, havendo redução relativa das atividades de pesquisa (pura e aplicada) e de desenvolvimento de produto em favor das atividades de adaptação local de produtos estrangeiros. (BAPTISTA, 1997).

É importante citar ainda alguns aspectos que podem ser considerados reflexos positivos da abertura de mercado. Esses seriam principalmente o incremento da diversidade de produtos ofertados no mercado nacional (via produção local ou importações), assim como a queda acentuada dos preços, que se reduziram em função da conjugação principalmente de quatro fatores: a abertura comercial, a isenção de IPI, a 
redução de custos resultante da modernização e racionalização dos processos produtivos, e da queda dos mark-ups praticados pelas empresas.

A breve análise realizada nesta seção permite apontar o contexto mais amplo no qual a política de informática brasileira foi implementada, sendo possível compreender melhor os resultados e números da indústria brasileira como repercussões não só das decisões governamentais e empresariais relacionadas à Lei 8.248/91, mas como reflexo de uma situação favorável no cenário mundial que se degrada a partir do ano 2000, e da completa reestruturação da indústria e das estratégias empresariais decorrentes da abertura de mercado e concorrência internacional.

\subsection{Resultados da política de informática brasileira a partir dos anos noventa}

Uma vez compreendidos os efeitos da abertura de mercado e o contexto mais abrangente pelo qual passava a indústria de informática global na década de noventa, cumpre descrever os resultados específicos gerados pela política governamental. Conforme já mencionado, a primeira grande avaliação da política foi feita em 1998, por iniciativa do MCT. Acredito que a importância e interesse em olhar este documento, com dados que precisariam ser complementados, está em compreender como o governo federal entende a política de informática, qual a visão dos policy-makers do MCT sobre esse assunto. Por esse motivo apresentarei em linhas gerais esse relatório. $\mathrm{O}$ estudo traz um discurso bem otimista quanto à política e aos rumos do setor. Deve-se contudo lembrar que esse documento foi elaborado durante o período de discussões sobre a primeira renovação dos incentivos. Assim, o objetivo do MCT era dar um embasamento mais aprofundado para a tese pró-renovação e, neste sentido, é de se esperar que superestimasse os pontos positivos e o papel da política no desenvolvimento do setor.

O mercado brasileiro é apontado como a maior indústria de informática e telecomunicações da América Latina, à luz do volume de negócios e da base de recursos humanos disponíveis. (SEPIN, 1998, p. 6). O setor é apresentado como em franca expansão, com taxa histórica de crescimento anual acima dos $10 \%$. Os investimentos totais das empresas em implantação, modernização e ampliação industrial cresceram mais de $400 \%$ nos cinco anos de vigência analisados (1993 - 1997). São ainda mencionados resultados favoráveis no comércio exterior. Após um recuo das exportações brasileiras no ano de 1994, chegando a 190 milhões de dólares, as vendas ao exterior cresceram 
substancialmente, atingindo o patamar de 566 milhões em apenas três anos (1997). A pauta de exportações era constituída principalmente de microcomputadores, terminais portáteis de telefonia celular e outros equipamentos de telecomunicações. Reconhece-se, entretanto, as limitações do país nesse setor. As exportações eram responsáveis por apenas $4 \%$ do faturamento no ano de 1997, atestando que o grande interesse das empresas aqui instaladas era mesmo o mercado interno. Além disso, mais da metade das exportações $(58 \%)$ eram dirigidas ao MERCOSUL ou ao Grupo Andino, dado que, embora reforce a tese de liderança regional do Brasil, também revela a incapacidade ou falta de interesse na conquista de grandes mercados centrais em países desenvolvidos (possivelmente devido à divisão global de atividades e vendas das multinacionais). (SEPIN, 1998, p. 21).

O grande resultado da política é identificado como os investimentos em pesquisa e desenvolvimento. Comemorou-se um montante de recursos na ordem de R 435 milhões nessa atividade, sendo mais da metade em pesquisa empresarial própria e o restante em convênios com instituições de ensino e pesquisa e programas prioritários do $\mathrm{MCT}$, como a Rede Nacional de Pesquisa - RNP, o programa SOFTEX e o Programa Temático Multiinstitucional em Ciência da Computação - ProTeM-CC. As principais alterações destacadas nos processos de pesquisa das empresas devido à implantação da lei foram: a melhoria no planejamento e acompanhamento das atividades de pesquisa de médio e longo prazo; o aumento do intercâmbio e da cooperação técnico-científica com universidades e centros de pesquisa; a modernização de linhas de produção; a criação de novas linhas de pesquisa e implantação de novos produtos; o incremento do esforço de nacionalização de partes, peças e componentes; e a ampliação e consolidação das equipes de engenharia de produtos, processos e sistemas ${ }^{46}$. (SEPIN, 1998, pp. 28-29).

O MCT não deixa de apontar algumas falhas da lei, como a ausência de uma política mais agressiva para o setor de componentes (semicondutores, componentes passivos e componentes eletromecânicos), e a forte alta das importações dessas partes e peças, decorrentes da forma como foi estruturado e regulamentado o plano produtivo básico e das estratégias de CKD implementadas pelas empresas. Entretanto, até mesmo pelo momento político sensível, esses problemas foram tratados com menor importância, e

\footnotetext{
${ }^{46}$ No próximo capítulo será realizada uma análise mais crítica dos resultados em P\&D da política de informática, tentando confrontar alguns dos resultados apresentados pelo MCT neste documento.
} 
a ênfase foi claramente dada aos aspectos positivos da Lei de Informática, e a importância de sua continuação.

Outros levantamentos foram realizados pelo governo federal em 2003 e 2006, já sob a égide das Lei 10.176/01 e 11.077/04, respectivamente, para o I e II Seminário Resultados da Lei de Informática. O tom permanece bem otimista, e os argumentos e resultados seguem basicamente a mesma linha daqueles apresentados no estudo de 1998 . Com base nesses documentos e em outras fontes, como dados publicados pela ABINEE e estudos do BNDES, elencarei os principais indicadores citados e utilizados para a avaliação e respaldo da política.

\section{a) Empresas beneficiadas e volume da renúncia fiscal}

Antes de tratar propriamente de resultados econômicos, vale destacar a abrangência conquistada pela política durante sua vigência. Possivelmente um dos melhores indicadores do acerto da política é a ampla adesão das empresas a seus termos, o que reforça suas condições vantajosas ${ }^{47}$. O MCT apontava que, de 1993 a 1998, 1.591 pleitos de incentivos haviam sido submetidos. Desses, 1.121 foram aprovados, havendo 272 empresas beneficiadas. A ampla maioria dos incentivos solicitados e aprovados referia-se ou incluía a isenção de IPI (solicitados: 1347 de 1591; aprovados: 971 de 1.121). Em junho de 2008, o MCT conta com 431 empresas credenciadas para os benefícios ${ }^{48}$. Possivelmente seguindo a nova orientação de não discriminação da origem do capital, os relatórios e apresentações de resultados do MCT não fazem qualquer referência ou reflexão sobre a origem dessas empresas, ou qual a parcela de capital nacional das beneficiadas.

O valor da renúncia fiscal com a redução de IPI e dos demais tributos (conforme a primeira versão da Lei de Informática) também cresceu substancialmente, revelando que a abrangência da política acompanhou o crescimento e bom momento do setor a partir da década de noventa. Em 1993, primeiro ano de vigência da política, essa renúncia foi de aproximadamente R \$ 5,8 milhões. Já em 2006, esse número subiu para R\$ 1.575 milhões (ambos os valores encontram-se atualizados com a inflação até 2005) ${ }^{49}$.

\footnotetext{
${ }^{47}$ Em sentido contrário poderia ser argumentado que esta adesão indica apenas uma estratégia oportunista de caça de rendas por parte das empresas, argumento que não refuto plenamente, mas julgo não invalidar a afirmação de que a ampla adesão representa um mérito da política.

${ }^{48}$ Informação extraída da página do MCT na internet < http://www.mct.gov.br> em 20.6.2008.

${ }^{49}$ Disponível em $<$ http://www.mct.gov.br/index.php/content/view/9252.html $>$. Acesso em 25.6.2008.
} 
O crescimento e magnitude do número de empresas incentivadas e da renúncia fiscal expressam o tamanho e importância do esforço governamental para promoção da indústria de informática. O MCT justifica essa renúncia demonstrando o quanto cresceu também nesse período o volume de tributos federais cobrados destas empresas. (SEPIN, 2003). É uma argumentação voltada para um público mais preocupado com a crise físcal do Estado brasileiro e a obtenção de superávits nas contas públicas. Os tributos não cobrados talvez seriam melhor justificados pelos resultados que a política de informática apresentou (ou deixou de apresentar), em especial no que tange à inovação tecnológica e no combate ao 'mercado cinza', conforme discutirei nos itens seguintes.

\section{b) Crescimento do setor; emprego na indústria}

Conforme já mencionado, o setor de informática apresentou crescimento expressivo durante todo o período de implantação da política, com saldo bem superior ao do restante da economia nacional. A tabela abaixo fornece uma dimensão mais exata desses números.

\begin{tabular}{|c|l|l|}
\hline \multicolumn{3}{|c|}{$\begin{array}{c}\text { Evolução do mercado - Comercialização Bruta } \\
\text { (em US\$ bilhões) }\end{array}$} \\
\hline Ano & $\begin{array}{c}\text { Total do setor (hardware, } \\
\text { software e serviços) }\end{array}$ & Hardware \\
\hline 1993 & 6.3 & 4.1 \\
\hline 1994 & 8.5 & 4.4 \\
\hline 1995 & 9.6 & 4.7 \\
\hline 1996 & 11.9 & 5.5 \\
\hline 1997 & 12.7 & 6.5 \\
\hline 1998 & 14.7 & 6.7 \\
\hline 1999 & 11.2 & 6.3 \\
\hline 2000 & 14.8 & 7.8 \\
\hline 2001 & 12.37 & 6.3 \\
\hline 2002 & 8.6 & 3.7 \\
\hline 2003 & 10 & 3.8 \\
\hline 2004 & 11.9 & 4.1 \\
\hline 2005 & 17.3 & 6.5 \\
\hline 2006 & 20.1 & 7.6 \\
\hline (Fonte: Anuário Informática Hoje 2007, disponível em \\
<http://www.anuarioih.com.br>. \\
$\begin{array}{l}\text { 19.6.2008) } \\
\text { Acesso }\end{array}$ \\
\hline
\end{tabular}

Conforme dados do MCT, esse crescimento na média foi bem superior ao da economia brasileira. Por essa razão a indústria mais do que dobrou sua participação relativa no PIB nacional, indo de apenas 1,7\% em 1991 para 3,5 em 2002 (último dado disponível publicado pelo MCT). (SEPIN, 2003).

Dados mais atualizados publicados pela ABINEE reforçam a tendência esboçada. Os indicadores da associação indicavam para 2007 um crescimento de 7\% no faturamento 
total para o setor de informática e de $8 \%$ para componentes elétricos e eletrônicos com relação a $2006^{50}$. O crescimento contínuo é atribuído principalmente aos programas do governo para a disseminação da tecnologia da informação ("Programa Computador para Todos"), às condições especiais de financiamento e às ações de combate ao contrabando e ao mercado cinza. Em 2007, as vendas de desktops e notebooks somaram 10 milhões de unidades, 21\% acima do ano anterior. O mercado de desktops, em 2007 foi de 8,1 milhões de unidades, $7 \%$ acima de 2006, enquanto que o mercado de notebooks atingiu 1,9 milhão de unidades, $183 \%$ acima do ano anterior. (ABINEE, 2008).

Nota-se que a indústria brasileira acompanhou a tendência de crescimento do setor no âmbito global. O setor de hardware teve um desempenho mais tímido, embora apresente grande importância no agregado da indústria, e sentiu fortemente a crise do início da década desse mercado (também acompanhando uma tendência global), tendo o valor de sua comercialização em 2004 voltado ao mesmo de 11 anos antes. ${ }^{51}$

Por esse motivo torna-se difícil dizer qual a influência da política no crescimento do setor. Conforme identificado, em praticamente todos os países desenvolvidos e naqueles com uma expressiva indústria de informática implantada o setor apresentou alto crescimento durante toda a década de noventa, retrocedendo ao início da década seguinte e iniciando uma retomada mais controlada posteriormente ao ajuste. O país acompanhou fielmente esses ciclos, o que não deixa clara a contribuição específica que poderia ser atribuída à política de informática.

Seria razoável apontar que, se não foi a responsável direta, a política de informática ao menos permitiu que o país tirasse proveito do cenário externo favorável. A diminuição da carga tributária e a exigência de pesquisas colaborou para o incentivo ao investimento e à instalação de fabricantes e revendedores locais, ainda que os segmentos de maior adensamento tecnológico não tenham acompanhado o movimento. Nesse sentido, afirmam Garcia e Roselino que a Lei de Informática exerceu papel fundamental na atração de empreendimentos de grandes empresas internacionais do complexo eletrônico, tanto de equipamentos para telecomunicações (como Lucent, Motorola, Nokia, Siemens, NEC,

\footnotetext{
${ }^{50}$ A ABINEE utiliza classificações e agregação de setores diferentes do MCT, embora os números sobre faturamento e comercialização sejam aproximados.

${ }^{51}$ Embora esta conta seja fortemente distorcida pela enorme diferença das taxas de câmbio nos dois períodos.
} 
Ericsson) como informática (Compaq, Texas Instruments). Foi responsável, também, pelo estabelecimento de uma rede de fornecedores locais, especialmente de empresas de manufatura (como Celestica, Solectron, Flextronics). Todas essas empresas declaram ter sido de fundamental importância a Lei de Informática para a atração dos investimentos e o estabelecimento e consolidação desses empreendimentos no Brasil. (GARCIA E ROSELINO, 2004).

Os mesmos autores, no entanto, questionam a importância da política, ao defender que a atração de investimentos também estaria vinculada à existência de fatores e capacitações constituída no período anterior, marcado pelo protecionismo e pela forte presença estatal. No segmento de telecomunicações especificamente, o desenvolvimento de capacitações pode ser tomado como resultado de uma política deliberada e centralizada do antigo sistema Telebrás, por meio da criação e da manutenção do CPqD. Mesmo a atração das grandes empresas internacionais de equipamentos para telecomunicações estaria mais relacionada ao contexto da privatização, que trazia uma perspectiva de expansão da demanda (comandada pelas operadoras de serviços e pelos requisitos da Lei Geral das Telecomunicações), do que com os mecanismos de estímulos da Lei de Informática. (GARCIA E ROSELINO, 2004).

Interessa notar que, possivelmente devido a processos de mecanização e modernização tecnológica, bem como ao baixo adensamento tecnológico e agregação de valor local efetuado pelas empresas, o emprego na indústria não acompanhou o crescimento nas vendas e faturamento do setor. No período de 1993 a 2002 (período no qual o MCT publicou dados a respeito) o emprego nas empresas beneficiadas permaneceu praticamente estável, na faixa de 33-35 mil empregos diretos (na realidade na maior parte dos anos os números foram um pouco inferiores). (SEPIN, 2003).

Segundo Tigre (2000), esse é um dado que pode ser ampliado para descrever todo o setor de TI. Em 1998 essa indústria brasileira empregava 100.000 pessoas, uma perda absoluta se comparada com os 129.615 empregos oferecidos pela indústria uma década antes. Em termos relativos, o emprego caiu de 22 empregados por milhão de dólares em 1988 para apenas 7 em 1998. O autor fornece duas possíveis explicações para esse fenômeno:

"Primeiro, a produtividade aumentou significativamente dos tempos de reserva de mercado para cá, como resultado do declínio da integração vertical e do uso de novas tecnologias. [...] Segundo, as empresas de capital nacional que 
operavam na indústria tendiam a empregar muito mais em termos relativos do que subsidiárias de firmas estrangeiras. As subsidiárias obtêm de suas matrizes pacotes prontos de tecnologias, componentes e serviços tendo assim menor necessidade de pessoal." (TIGRE, 2000).

c) Manutenção de parcela da estrutura de produção e incapacidade de incentivos para uma indústria de componentes

Conforme mencionado, um dos efeitos mais deletérios da abertura comercial foi a desestruturação de grande parte da cadeia produtiva. Este movimento implicou a interrupção do processo de formação de redes de fornecedores especializados (de componentes e periféricos) que vinha se vinha consolidando ao longo do período da reserva de mercado e que constituía uma externalidade relevante propiciada por esta política.

A política de informática (especialmente a isenção de IPI) teve a virtude de limitar esse movimento no que se refere aos produtos finais. Ao exigir um mínimo de agregação local através do PPB, este incentivo favoreceu a montagem de produtos finais no país e, por consequência, incentivou a realização de investimentos produtivos. Neste sentido, conforme Baptista, "é razoável argumentar-se que, na ausência destes incentivos, a tendência seria um aumento ainda maior (do ponto de vista quantitativo) deste processo de substituição de produção local por importações (no que tange aos produtos finais de informática) e a redução mais pronunciada nos investimentos realizados.” (BAPTISTA, 1997).

Por outro lado, a política foi incapaz de manter ou atrair uma indústria de componentes que tivesse competitividade no mercado internacional. Os fabricantes que aqui havia durante a década de oitenta em sua quase totalidade não subsistiram a uma concorrência internacional com escala superior. Apenas no ano de 1992, esse segmento teve redução de mais de 60\% nas vendas, resultante da maior facilidade de importar placas eletrônicas já montadas. Mesmo algumas empresas estrangeiras que produziam aqui alguns tipos de componente foram forçadas a desativar suas linhas de produção devido à pequena escala do mercado, o que levava à inviabilidade dos empreendimentos.

A importância desse segmento é vital para a constituição de uma indústria de informática. Conforme estudo publicado pelo BNDES, a fabricação de bens eletrônicos, se não se fizer acompanhar da produção de componentes, dificilmente é capaz de englobar atividades de projeto completo ou desfrutar de custos largamente competitivos. Isso porque a miniaturização dos produtos eletrônicos vem sendo obtida a partir da diminuição do número de 
circuitos e da integração de vários deles em pequenos chips, o que tem impactos diretos sobre o projeto do bem final e sobre o seu custo. (MELO, 1999).

O peso dos componentes e periféricos sobre o custo total é mais crítico quanto mais "amadurecido" ou padronizado estiver o produto final. Assim, os segmentos mais impactados por esse custo acabam sendo os bens de consumo e a parte da informática referente à computação pessoal (microcomputadores domésticos), por suas economias de escala especialmente altas. (MELO, 1999).

Há que se considerar, no entanto, que o "parto" e desenvolvimento de uma indústria local de componentes é um problema que envolve questões de grande complexidade, que se encontram fora dos objetivos para os quais foi elaborada e implementada a política de informática. Novamente conforme exposto em estudo publicado pelo BNDES, a autonomia tecnológica e mesmo a atração de investimentos estrangeiros diretos para esse segmento não são problemas de fácil solução.

\footnotetext{
“Os componentes eletrônicos semicondutores, em particular, além de constituírem o ramo mais avançado e dinâmico em termos de progresso técnico, requerem vultosas somas de capital para montagem das unidades produtivas. Ademais, por estarem sujeitos a gigantescas economias de escala originadas no nível das plantas, muitas vezes o tamanho do mercado de países em desenvolvimento é insuficiente para assegurar a rentabilidade do empreendimento no longo prazo. Não por acaso, a oferta mundial de semicondutores provém de um número reduzido de fábricas concentradas no espaço econômico global. A atração de investimentos estrangeiros para realizar a produção de semicondutores no Brasil fica condicionada a estratégias de política industrial, cujos instrumentos envolvem incentivos públicos destinados a minorar os riscos inerentes aos elevados custos fixos de capital." (NASSIF, 2002, grifos nossos).
}

Dessa forma, a questão da indústria de componentes parece constituir objetivo de Estado que se encontra fora do âmbito da política de informática, tal como atualmente delineada. Seria um equívoco, nesses termos, julgar a eficácia e efetividade de uma política pública por um problema que ela não foi desenhada para resolver, e não tinha elementos e ações adequadas para abordar.

Não se pretende com isso afirmar que não deva ser objetivo do governo federal envidar esforços para, na medida do possível, atrair uma indústria de componentes e semicondutores. Esse debate, por sinal, recorrentemente vem à tona, com tentativas para sua solução. Uma parceria do governo federal com o governo do Rio Grande do Sul, a cidade de Porto Alegre e entes privados deu origem ao Centro de Excelência em Tecnologia Eletrônica Avançada - 
CEITEC, que promete constituir a primeira fábrica de semicondutores no Brasil, uma tentativa ousada com forte capital estatal, cujo objetivo é reinserir o país no mapa da microeletrônica no mundo ${ }^{52}$.

Mas, com base na experiência da política desenvolvida até aqui, a mera isenção fiscal e compromisso de recursos com pesquisa não pareceram ser suficientes para solucionar os problemas de economias de escalas e barreiras de entrada (volume de capital) que devem ser superados para a instalação de uma indústria de componentes, especialmente de semicondutores.

\section{d) Déficit na balança comercial}

O diagnóstico feito no item anterior quanto à indústria de componentes é especialmente sentido na análise da balança comercial brasileira. A composição da pauta de importações do complexo eletrônico e o seu volume revelam a dependência crítica da indústria brasileira por partes e peças, e também que o crescimento do setor a partir da abertura de mercado foi essencialmente baseado na aquisição para montagem ou simplesmente revenda de produtos fabricados no exterior.

\begin{tabular}{|c|c|c|c|c|c|c|c|}
\hline DISCRIMINAÇÃO & 1996 & 1997 & 1998 & 1999 & 2000 & 2001 & 2002 \\
\hline IMPORTAÇŌES & $6.859,19$ & $7.874,95$ & $7.107,57$ & $6.891,79$ & $9.277,56$ & $8.839,18$ & $5.713,27$ \\
\hline Informática & $1.454,30$ & $1.489,10$ & $1.528,70$ & $1.447,00$ & $1.853,00$ & $1.715,10$ & $1.306,70$ \\
\hline Eletrônica de Consumo & $1.037,10$ & $1.048,40$ & 622,70 & 370,50 & 411,50 & 361,20 & 424,30 \\
\hline Telecomunicaçōes & $2.087,49$ & $2.752,55$ & $2.682,07$ & $2.710,79$ & $3.434,86$ & $3.752,88$ & $1.510,77$ \\
\hline Componentes & $2.280,30$ & $2.584,90$ & $2.274,10$ & $2.363,50$ & $3.578,20$ & $3.010,00$ & $2.472,10$ \\
\hline EXPORTAÇÖES & $1.049,41$ & $1.199,45$ & $1.188,60$ & $1.445,30$ & $2.491,70$ & $2.571,48$ & $2.403,10$ \\
\hline Informática & 280,70 & 267,90 & 247,30 & 336,80 & 374,70 & 293,00 & 163,70 \\
\hline Eletrônica de Consumo & 386,10 & 411,40 & 371,00 & 353,50 & 433,70 & 385,40 & 279,80 \\
\hline Telecomunicaçōes & 154,11 & 288,25 & 329,50 & 494,20 & $1.311,30$ & $1.551,88$ & $1.547,30$ \\
\hline Componentes & 228,50 & 231,90 & 240,80 & 260,80 & 372,00 & 341,20 & 412,30 \\
\hline DÉFICIT & $(5.809,78)$ & $(6.675,51)$ & $5.918,97)$ & $(5.446,49)$ & $6.785,86)$ & $6.267,70)$ & $(3.310,77$ \\
\hline
\end{tabular}

(Fonte: GUTIERREZ E ALEXANDRE, 2003)

\footnotetext{
${ }^{52}$ Para mais informações sobre o projeto $<$ http://www.ceitecmicrossistemas.org.br>. Acesso em 8 jan. 2009.
} 
Brasil: Balança Comercial do Segmento de Informática - 1996-2003 (Em US\$ Milhões)

\begin{tabular}{|c|c|c|c|c|c|c|c|}
\hline DISCRIMINAÇÃO & 1996 & 1997 & 1998 & 1999 & 2000 & 2001 & 2002 \\
\hline IMPORTAÇÕES & $1.454,30$ & $1.489,10$ & $1.528,70$ & $1.447,00$ & $1.853,00$ & $1.715,10$ & $1.306,70$ \\
\hline Computadores & 201,20 & 198,90 & 169,40 & 144,60 & 190,70 & 181,60 & 127,30 \\
\hline Monitores de Vídeo & 114,10 & 55,20 & 45,10 & 22,60 & 20,30 & 18,20 & 17,80 \\
\hline Impressoras & 147,80 & 138,10 & 126,20 & 54,90 & 62,30 & 68,70 & 57,60 \\
\hline Unidades de Disco Rígido & 166,30 & 194,90 & 198,20 & 215,10 & 261,10 & 222,90 & 123,60 \\
\hline Unidades de Disco Óptico & 46,90 & 44,70 & 42,30 & 35,70 & 65,80 & 57,10 & 34,90 \\
\hline Gateways e Hubs & 100,90 & 87,40 & 72,50 & 73,00 & 84,50 & 69,40 & 44,90 \\
\hline Terminais de Auto-Atendimento & 6,60 & 2,00 & 7,60 & 12,20 & 0,10 & 0,20 & 0,00 \\
\hline $\begin{array}{l}\text { Outros p/ Autom. Escritórios, } \\
\text { Bancária e Comercial }\end{array}$ & 10,20 & 8,30 & 11,20 & 43,10 & 43,30 & 41,00 & 35,30 \\
\hline Outros Equipamentos de Informática & 214,20 & 326,80 & 313,00 & 268,00 & 345,90 & 352,40 & 274,40 \\
\hline Partes e Peças & 446,10 & 432,80 & 543,20 & 577,80 & 779,00 & 703,60 & 590,90 \\
\hline EXPORTAÇÕES & 280,70 & 267,90 & 247,30 & 336,80 & 374,70 & 293,00 & 163,70 \\
\hline Computadores & 163,30 & 198,30 & 178,10 & 248,80 & 203,00 & 106,20 & 26,30 \\
\hline Monitores de Vídeo & 7,80 & 3,20 & 11,50 & 21,70 & 62,40 & 56,80 & 28,40 \\
\hline Impressoras & 3,80 & 1,00 & 2,60 & 11,70 & 24,10 & 28,50 & 19,20 \\
\hline Unidades de Disco Rígido & 8,90 & 9,50 & 5,90 & 7,30 & 9,60 & 14,50 & 12,50 \\
\hline Unidades de Disco Óptico & 0,20 & 1,10 & 0,40 & 0,40 & 0,70 & 1,00 & 0,40 \\
\hline Gateways e Hubs & 7,10 & 0,30 & 1,30 & 0,80 & 1,80 & 0,40 & 0,90 \\
\hline Terminais de Auto-Atendimento & 0,00 & 0,00 & 0,00 & 0,50 & 0,20 & 0,30 & 0,40 \\
\hline $\begin{array}{l}\text { Outros p/ Autom. Escritórios, } \\
\text { Bancária e Comercial }\end{array}$ & 0,50 & 3,20 & 2,10 & 3,30 & 6,40 & 2,10 & 4,70 \\
\hline Outros Equipamentos de Informática & 8,20 & 17,60 & 17,00 & 13,30 & 27,20 & 33,30 & 22,50 \\
\hline Partes e Peças & 80,90 & 33,70 & 28,40 & 29,00 & 39,30 & 49,90 & 48,40 \\
\hline
\end{tabular}

DÉFICIT $\quad(1.173,60)(1.221,20)(1.281,40)(1.110,20)(1.478,30)(1.422,10)(1.143,00)$

(Fonte: GUTIERREZ E ALEXANDRE, 2003)

Apesar de o alto déficit comercial do complexo eletrônico ser em maior parte um processo decorrente da abertura do mercado à concorrência externa e ao forte aquecimento do setor no período, a política implementada pelo governo trouxe reflexos. O PPB não exige o uso de componentes e partes produzidos localmente, admitindo que os incentivos sejam obtidos através da montagem de produtos no estilo CKD.

Por essa razão, enquanto a importação de componentes, partes e peças apresentou um peso significativo na balança comercial do período, o item de produtos finais permaneceu em um nível razoavelmente sob controle. Isso ocorre pois, considerando a racionalidade e lógica da política, valia a pena, sob uma perspectiva estritamente comercial de resultados, realizar a etapa final de fabricação no país, obtendo os incentivos fiscais que davam competitividade frente a produtos finais importados, que não dispunham das mesmas vantagens obtidas pelos bens beneficiados. 
Dados mais atualizados publicados pela ABINEE confirmam que as tendências esboçadas acima não se alteraram nos últimos anos. $\mathrm{O}$ crescimento dos setores de informática e telecomunicações continuam pressionando enormemente as importações, especialmente de partes e componentes. A grande novidade dos últimos anos é o crescimento das importações advindas do sudeste asiático. Esse bloco ganhou bastante espaço na pauta brasileira nos últimos anos, e vem consolidando sua posição como principal fornecedor, representando 61\% das importações no ano de 2007 da indústria eletroeletrônica.

\begin{tabular}{|l|c|c|c|c|}
\hline $\begin{array}{c}\text { Importações de Produtos do Setor } \\
\text { (US\$ milhões) }\end{array}$ & $\mathbf{2 0 0 5}$ & $\mathbf{2 0 0 6}$ & $\mathbf{2 0 0 7}$ & $\frac{\mathbf{2 0 0 7} X}{\mathbf{2 0 0 6}}$ \\
\hline Automação Industrial & 829 & 1.326 & 1.757 & $33 \%$ \\
\hline Componentes Elétricos e Eletrônicos & 9.617 & 11.910 & 13.648 & $15 \%$ \\
\hline Equipamentos Industriais & 950 & 1.519 & 1.892 & $25 \%$ \\
\hline GTD & 223 & 310 & 388 & $25 \%$ \\
\hline Informática & 1.018 & 1.400 & 1.883 & $35 \%$ \\
\hline Material Elétrico de Instalação & 570 & 652 & 756 & $16 \%$ \\
\hline Telecomunicações & 1.094 & 1.235 & 2.019 & $64 \%$ \\
\hline Utilidades Domésticas Eletroeletrônicas & 835 & 1.355 & 1.707 & $26 \%$ \\
\hline Total & $\mathbf{1 5 . 1 3 5}$ & $\mathbf{1 9 . 7 0 5}$ & $\mathbf{2 4 . 0 5 0}$ & $\mathbf{2 2 \%}$ \\
\hline
\end{tabular}

(Fonte: Desempenho setorial 2008 - ABINEE. Disponível em $<$ http://www.abinee.org.br/abinee/decon/ decon15.htm>. Acesso em 22.6.1008. )

\begin{tabular}{|l|c|c|c|}
\hline \multicolumn{1}{|c|}{$\begin{array}{c}\text { Produtos mais Importados } \\
\text { (US\$ milhões) }\end{array}$} & $\mathbf{2 0 0 6}$ & $\mathbf{2 0 0 7}$ & $\frac{\mathbf{2 0 0 7} \mathbf{X}}{\mathbf{2 0 0 6}}$ \\
\hline Semicondutores & 3.332 & 3.423 & $3 \%$ \\
\hline Componentes para Informática & 2.178 & 3.089 & $42 \%$ \\
\hline Componentes para Telecomunicações & 2.420 & 2.650 & $9 \%$ \\
\hline Instrumentos de Medida & 797 & 975 & $22 \%$ \\
\hline Outros Equips. Informática & 649 & 890 & $37 \%$ \\
\hline Eletrônica Embarcada & 657 & 885 & $35 \%$ \\
\hline Outros Equips. Industriais & 596 & 773 & $30 \%$ \\
\hline Comp. p/ Equips. Industriais & 620 & 627 & $1 \%$ \\
\hline Outros Eletrodomésticos & 329 & 521 & $59 \%$ \\
\hline Outros Mat. Elet. Instalação & 356 & 496 & $39 \%$ \\
\hline
\end{tabular}

\section{e) Diminuição dos preços e disseminação tecnológica}

A política de informática coleciona alguns consideráveis efeitos positivos ao longo de sua trajetória, especialmente sua contribuição para redução dos preços e disseminação do uso de tecnologias da informação e comunicação no país. Segundo Tigre, os preços começaram a cair mesmo antes do fim da reserva de mercado, por causa da competição e menores tarifas alfandegárias. Entre 1985 e 1989 o diferencial de preços entre o Brasil e os Estados Unidos diminuiu para todos os produtos de TI. Em 1989, antes do início das políticas de liberalização, o preço de microcomputadores no Brasil era apenas 15\% maior 
do que na Inglaterra e na França. Após a abertura, os preços dos PCs no Brasil passaram para um patamar equivalente a 25-30\% maior do que os preços nos EUA e similar aos preços observados na Europa, onde maiores impostos e margens de comercialização contribuíram para a estabelecer a diferença. (TIGRE, 2000).

A disseminação do uso das TIC no Brasil é um fenômeno relativamente recente, que ganhou grande força a partir dos anos noventa e, em especial, na década seguinte. Conforme dados do Comitê Gestor da Internet no Brasil (TIC Domicílios e TIC Empresas 2006), houve melhoria nos índices de acesso ao computador e à internet. O índice de pessoas que já utilizaram um computador passou de 45,2\% da população em 2005 para $45,7 \%$ em 2006. O número de pessoas que havia utilizado um computador nos últimos três meses anteriores à pesquisa passou de 29,7\% para 33,1\%. O índice dos que já acessaram a internet cresceu de $32,2 \%$ para $33,3 \%$ e dos que utilizaram a internet nos últimos três meses aumentou de 24,4\% para 27,8\%. Já o percentual dos que nunca utilizaram o computador e a internet caiu de $54,8 \%$ para $54,3 \%$ e de $67,8 \%$ para $66,7 \%$, respectivamente. (SANTOS, 2007).

Esses dois fenômenos obviamente não são decorrência exclusiva do apoio governamental. A própria abertura dos mercados dos anos noventa e o progresso tecnológico contínuo (a contínua validade da Lei de Moore ao longo de décadas) foram fatores que influenciaram na queda acentuada dos preços e conseqüente popularização das tecnologias da informação, diminuindo o mapa da exclusão digital no Brasil e no mundo. A renúncia fiscal exercida pelo governo através da política de informática, entretanto, acelerou esse processo, barateando os preços de insumos e do produto final disponível ao consumidor, aquecendo esse mercado e permitindo que classes com menores rendas tenham acesso a esses equipamentos.

A inclusão digital, por sinal, vem sendo objeto de políticas públicas em todo o mundo. Cada vez mais se percebe a importância e os benefícios de uma população e uma mão-de-obra qualificada para trabalhar com equipamentos sofisticados. No âmbito político, questões como transparência governamental, participação democrática e prestação de serviços públicos estão sendo afetadas pelas tecnologias da informação e comunicação de diversas formas, e com perspectivas positivas. No Brasil, além da política de informática surgiram outras ações governamentais nos diversos níveis federativos para 
tentar equacionar essa questão. Exemplos dessas ações são o programa "Computador para Todos" do governo federal e os telecentros no estado de São Paulo.

\section{f) Combate ao mercado cinza}

O chamado "mercado cinza", ou o mercado de produtos oriundos de contrabando ou de importações ilegais de equipamentos ou partes e peças, é talvez o maior dos problemas enfrentados pela indústria de informática brasileira contemporânea. Conforme dados de 2002, o mercado cinza era responsável por mais de $50 \%$ das vendas do segmento de microcomputadores tipo desktops, mercado avaliado à época em cerca de 3 milhões de máquinas. (GUTIERREZ E ALEXANDRE, 2003, p. 174).

Ter toda essa parcela do mercado nas mãos do mercado cinza significa que, além de enormes evasões fiscais decorrentes do não recolhimento de impostos, ficam comprometidas as iniciativas de adensamento da cadeia produtiva. Os fornecedores individuais identificados pelos autores citados tinham normalmente participação inferior a $6 \%$ no total do mercado. Em um setor marcado por economias de escala essa característica não só se torna um grande empecilho ao desenvolvimento das firmas como também impõe severos riscos a sua sobrevivência. (GUTIERREZ E ALEXANDRE, 2003, p. 174).

É importante citar que o mercado cinza consegue obter grandes reduções de custos não apenas através da importação ilegal e evasão fiscal de partes e componentes, como também através da utilização de cópias ilegais (piratas) de sistemas operacionais, aplicativos e outros programas.

Apesar de não constituir medida que, isoladamente, vá extinguir a ilegalidade e o mercado cinza, a política de informática tem um papel importante na reversão desse cenário, especialmente por dois motivos. Em primeiro lugar, com a redução da carga tributária incidente sobre os equipamentos formalmente produzidos, diminui-se a diferença de custos desses bens para os vendidos irregularmente, incentivando assim os consumidores a abandonar esses últimos.

Pode-se argumentar contrariamente, no sentido de que essa redução não extingue totalmente a diferença de preços, e portanto os compradores continuariam propensos a adquirir os bens mais baratos do mercado cinza. Esse argumento, todavia, não leva em 
consideração o fato de os consumidores identificarem alguma utilidade na aquisição de produtos legais. Essa utilidade seria constituída, entre outros elementos, pela garantia do produto, pela segurança de um fornecedor confiável e estável e de uma compra protegida pelo ordenamento jurídico (em especial pelo Código de Defesa do Consumidor), e, ainda, por não estar adquirindo produto ilegal, incorrendo em penalidade prevista pela legislação e por violação de direito autoral.

O segundo motivo pelo qual a política de informática colabora com a redução do contrabando é o compromisso das empresas beneficiárias seguirem o projeto de fabricação previsto no PPB, abstendo-se assim de utilizar o mercado cinza para o fornecimento de componentes para seus equipamentos. Exclui-se dessa forma uma soma significativa de empresas e de seus consumidores da compra e utilização desses bens, fomentando o mercado regular de partes e peças.

Uma alteração na Lei de Informática trazida pela Lei 10.664/03 permitiu a redução em $50 \%$ da aplicação em pesquisa e desenvolvimento referente ao faturamento bruto para o mercado interno sobre microcomputadores de valor até $\mathrm{R} \$ 11 \mathrm{mil}$, ao mesmo tempo em que elevou os percentuais de benefício da redução do IPI devido pelas fabricantes de tais produtos. Foi realizada também uma revisão das tarifas de importação incidentes sobre componentes, partes e peças dos microcomputadores, de forma a desonerar a produção nacional. Essas foram medidas governamentais que buscaram se utilizar da lógica instituída pela Lei de Informática para minorar a atratividade do "mercado cinza". (GUTIERREZ E ALEXANDRE, 2003).

Dados atualizados da ABINEE indicam uma tendência de queda relativa no contrabando e crescimento do mercado formal com relação aos números anteriormente citados. A associação credita a melhora no quadro à continuidade dos programas do governo para a disseminação da tecnologia da informação (a política de informática, a "Lei do Bem" e o "Programa Computador para Todos" seriam os maiores expoentes), às condições especiais de financiamento e às ações de combate ao contrabando. Em 2007, as vendas de desktops e notebooks somaram 10 milhões de unidades, $21 \%$ acima do ano anterior. Deste montante, 6,5 milhões foram produzidos pelas empresas formais, com 
crescimento de 48\% em relação ao ano anterior. Em 2007, a participação da indústria legal no mercado de PCs atingiu $65 \%$, nível superior ao observado em 2006, de 53\%. ${ }^{53}$

3.10 Análise da política de informática à luz dos elementos teóricos

Nas partes anteriores tentei realizar uma reconstrução histórica da atual política de informática e seus eventos políticos e econômicos relevantes. Sendo esta uma história que poderia ser narrada sob diferentes pontos de vista, procurei dar uma maior ênfase aos elementos normativos e jurídicos, bem como aos fatos que os tenham influenciado e suas repercussões para o setor.

Neste item, como uma conclusão a essa análise, elenco os principais pontos e questões que entendo relevantes ou que se sobressaiam. Se possível tentarei extrair lições ou problemas que possam ser generalizados para o debate de políticas públicas econômicas ou setoriais, ou ainda que dialoguem com as formulações teóricas discutidas nos capítulos prévios.

a) a importância estratégica da indústria de informática e do segmento de hardware

Os anos noventa e seguintes viram um decréscimo notável do valor e importância relativa dos equipamentos e bens de hardware nos gastos com TICs. Estudo da OCDE datado do início da década já apontava firmemente essa tendência. Não se trataria, segundo esse estudo, de uma crise específica nesse segmento. Com o advento da internet, as grandes empresas fabricantes de hardware passaram a ofertar serviços em maior escala, alterando moderadamente seu objeto e composição de faturamento ${ }^{54}$.

Dois estudiosos que identificaram esse fenômeno bem cedo foram Tapscott e Caston. Em seu trabalho que se tornou uma referência no tema, os autores buscam inserir o declínio do hardware e emergência de software e serviços em um novo modelo, uma "mudança de paradigma" a partir da qual deveria emergir uma segunda era da tecnologia da informação. O principal motivo para o declínio do hardware seria a sua acelerada comoditização.

53 Conforme ABINEE. Desempenho Setorial 2008. Disponível em <http://www.abinee.org.br/ abinee/decon/decon15.htm>. Acesso em 22.6.1008.

54 "With the increasing importance of the Internet, major firms that traditionally dealt in hardware are shifting their focus to services, particularly Web-based or e-business services". (OECD, 2000, p. 37). 


\begin{abstract}
"Atualmente o hardware tem se tornado uma base para microprocessadores, e padrões de software permitem a portabilidade da informação e de aplicativos [...] esses fatores libertam os consumidores para mudar o fornecedor de seus processadores pagando uma pena mínima. Como resultado, o hardware de computador está mudando para se tornar uma categoria de produtos commodity de baixo custo e margem". (TAPSCOTT E CASTON, 1993, p. 301, tradução nossa, grifos nossos). ${ }^{55}$
\end{abstract}

Com o processo de padronização e diminuição dos custos dos equipamentos, o mercado sofreria uma reestruturação, levando a maior parte do faturamento e lucro das empresas de TI a vir de outras fontes, especialmente software e serviços. "Hardware vem caindo drasticamente como um veículo para agregar valor; [...] quando se leva em consideração que as margens nos componentes de hardware vêm declinando, torna-se claro que a maior parte do lucro da indústria será com software e serviços." (TAPSCOTT E CASTON, 1993, p. 304, tradução nossa). ${ }^{56}$

O desenvolvimento posterior da indústria de TI no mundo confirmou em grande parte essa previsão de Tapscott e Caston (embora certamente em uma velocidade inferior à inicialmente prevista pelos autores). Especialmente no caso dos computadores pessoais, a guerra de preços entre fabricantes e o declínio constante dos custos de componentes têm apresentado como conseqüência uma queda acentuada dos preços finais ao consumidor ${ }^{57}$.

Considerando essas características, seria importante questionar qual o sentido de uma política marcadamente voltada para o setor de hardware. Sendo esse um segmento já em fase de maturação (conforme tipologia de Perez e Soete, 1998), com preços declinantes e tecnologia padronizada e difundida, poder-se-ia argumentar que o governo não deveria despender recursos em sua promoção, devendo, ao contrário, deixar que os incentivos de mercado determinem os fabricantes e preços a serem praticados.

Acredito que a essa é uma indagação que encontra resposta suficiente no histórico da política, em especial considerando seus resultados. Se é verdade que a indústria de

\footnotetext{
55 "Now all hardware is becoming base for microprocessors, and software standards enable portability of information and software applications [...] these factors free customers to switch suppliers of mainstream processors with minimal penalty. As a result, computer hardware is changing to become a low-cost, lowmargin commodity product category". (TAPSCOTT E CASTON, 1993, p. 301).

56 "Hardware has declined dramatically as a vehicle for adding value; [...] when you consider that margins in the hardware component are declining, it is clear that most of the profit to be made in the industry will be in software and services". (TAPSCOTT E CASTON, 1993, p. 304).

${ }^{57}$ OECD, 2002, p. 40 e seguintes. O estudo apresenta uma série de gráficos que confirmam essa tendência, e demonstrando ainda como esse processo se deu mais acentuadamente no segmento de PCs.
} 
equipamentos de informática apresenta uma tendência de comoditização e queda de preços, também é fato que estes itens, desde a abertura de mercado, apresentam forte peso deficitário na balança comercial brasileira. E os dados mais recentes publicados pelo MCT e pela ABINEE não parecem demonstrar qualquer tendência de reversão desse cenário. Assim, o declínio nos preços de equipamentos não parece resultar em igual diminuição no valor dos produtos importados.

Na medida em que, conforme identificado, a política de informática impediu, ao menos em parte, que esse fenômeno ficasse restrito ao segmento de partes e componentes, não se alastrando aos produtos finais, parece haver aí uma boa justificativa para sua manutenção. Sua importância se revelaria, dentro desse quadro, em sua contribuição para suavizar o déficit do comércio internacional brasileiro no setor eletro-eletrônico.

Pode ser argumentado, em sentido contrário, que comércio internacional de bens e serviços é um tema que não pode ser abordado setorialmente e que essa seria uma questão a ser compreendida sob o prisma das vantagens comparativas de cada país. Entretanto, sob uma perspectiva dinâmica e evolucionária a construção de uma vantagem competitiva que reduzisse ou melhorasse a posição de uma nação no cenário de trocas internacionais seria plenamente justificável.

Outra razão que pode ser levantada a partir do histórico é a contribuição da política de informática para redução dos preços dos equipamentos e a disseminação das tecnologias da informação na sociedade brasileira. Conforme identificado, a inclusão digital tem um potencial significativo para melhoria da participação política dos cidadãos, obtenção de conhecimento e informações, aumento de oportunidades econômicas, dentre outros benefícios. Uma vez que um dos grandes gargalos para a inclusão digital no Brasil constitui-se no preço de computadores pessoais e demais periféricos, uma política que contribua para sua redução pode ser considerada oportuna e realizadora de objetivos de Estado.

b) Alteração das bases do debate sobre a política de informática

Ao longo da década de noventa o cerne teórico e ideológico do debate da política de informática foi profundamente alterado. A herança anterior e os momentos econômicos difíceis do país não permitiram que essa alteração se delineasse com clareza no princípio, 
mas ao final da década a política de informática já havia completado esse percurso, tornando-se, a partir de um tema altamente polêmico e que suscitava questionamentos teóricos profundos, um assunto discutido e resolvido consideradas apenas conveniências políticas e forças parlamentares regionais.

Dessa forma, em linhas gerais pode-se delinear dois momentos no que tange ao fundo teórico do debate sobre a política de informática pós anos oitenta. O princípio, que foi marcado por um embate entre uma visão liberal, de fundo neoclássica, propondo a extinção rápida da reserva de mercado e a supressão de qualquer política posterior, e um projeto que preservava alguma margem de atuação estatal, com viés que pode ser considerado neoschumpeteriano. E um segundo momento no qual se percebe a ausência de um fulcro teórico econômico lastreando o debate, passando este a ser baseado no conflito com os partidários da ZFM.

Conforme identificado no capítulo anterior, a reserva de mercado e conjunto de ações governamentais nas décadas de setenta e oitenta estão muito próximos de uma clássica estratégia de estufa, nos termos inicialmente propostos por List. A partir da década de noventa se torna impossível ao Brasil continuar com esse modelo de desenvolvimento. As pressões externas, as regras rígidas de tratados internacionais sobre o livre comércio e as diversas críticas e problemas ressaltados por empresários e consumidores inviabilizam a continuidade da política. $\mathrm{Na}$ emergência do novo modelo e nos debates parlamentares sobre a Lei 8.248/91 ficam claras as novas opções, podendo-se traçar um paralelo teórico de cada.

A proposta marcadamente liberal é aquela defendida por Roberto Campos e pelo MEFP da época. Sua idéia central constituía na rápida abertura do setor à concorrência externa, firme extinção de quaisquer benefícios às empresas nacionais e restrições ao capital externo. Nessa visão a política anterior seria completamente desmantelada, devendo o Estado se abster de qualquer nova intervenção no setor. O curto texto desse projeto evidencia o absenteísmo estatal de sua proposta.

O projeto do MEFP e de Campos tem um claro alinhamento teórico neoclássico. A idéia de exclusão do Estado do jogo econômico que determina os bens a serem produzidos ou importados revela uma crença no livre mercado como melhor forma de se atingir uma 
alocação eficiente de recursos. Esses agentes identificavam na antiga política uma intervenção indevida do setor público, geradora de rendas e de ineficiências econômicas. Por esse motivo cumpria extinguir o mais rápido possível essa ação governamental, deixando que o mercado restaurasse a contento a alocação ótima dos recursos. Sob esse viés não há qualquer espaço para reflexão sobre a constituição de capacitação tecnológica local, desenvolvimento industrial ou construção de vantagens comparativas ao longo do tempo. Não haveria, assim, qualquer necessidade para uma nova política de informática. $\mathrm{O}$ desenrolar do comércio, liberado de amarras restritivas, definiria se as empresas brasileiras de informática teriam condições de competir com seus concorrentes externos, ou se, ao contrário, elas representavam um investimento equivocado de capital e recursos humanos.

A proposta alternativa, representada pela primeira versão do substitutivo Luiz Henrique, apresentava uma preocupação com a construção e manutenção de capacitação tecnológica nacional. O governo federal preservaria uma margem de manobra para intervenção no setor, especialmente considerando as regras e restrições para formação de joint-ventures e para entrada do capital externo, e os incentivos fiscais às empresas locais.

Neste segundo projeto, que acabou sendo a base da Lei de Informática, podem-se vislumbrar elementos de cunho neoschumpeteriano. Sem se desligar da idéia de concorrência de mercado, trata-se de uma abordagem que encara a política industrial de uma forma abrangente, não restrita à correção de falhas de mercado. O Estado teria um papel importante e ativo na preservação das capacidades tecnológicas e empresariais já construídas, e na promoção da competitividade para que essas empresas (ou algumas que sobrevivessem à abertura) pudessem se manter no mercado. Conforme exposto no primeiro capítulo, a corrente neoschumpeteriana aceita e propõe tanto medidas de cunho horizontal como mecanismos seletivos de política (verticalidade), levando empresas ao aprimoramento e à busca de métodos mais eficientes de produção no longo prazo (eficiência dinâmica).

O resultado desse embate, conforme já apontado, foi uma lei que tentou conciliar essas duas visões e seus respectivos defensores. Embora o substitutivo Luiz Henrique tenha na prática suplantado a proposta inicial do MEFP, para ser aprovado no Congresso Nacional ele precisou ser severamente abrandado. As medidas de restrições ao capital externo e à constituição de parcerias internacionais foram excluídas. Mantiveram-se, no 
entanto, outras formas e possibilidades da atuação estatal verticais para implementação de uma política industrial, como os incentivos fiscais descritos, a preferência na compras governamentais e as contrapartidas em pesquisa e desenvolvimento.

Posteriormente à aprovação da lei e seus primeiros atos normativos de regulamentação, esse debate em grande parte perde seu sentido. Não havendo restrições ao capital externo e às multinacionais que quisessem operar no país, não havia grandes motivos para críticos liberais se oporem à política de informática tal como estabelecida. Sua adequação à PICE do governo Collor de Mello a resguardava de críticas nesse sentido. E, por outro lado, exceto por vozes isoladas, cessaram maiores tentativas de implementação de uma política industrial mais forte e incisiva para o setor de informática.

O segundo momento das discussões sobre a política se dá a partir de 1998, quando da necessidade de sua renovação, e posteriormente em 2003, nos debates parlamentares que resultaram na Emenda Constitucional 42/03. Os relatos e o histórico dessas prorrogações revelam que o cerne da discussão no período não parece estar relacionado com divergentes fundamentações teóricas no campo econômico ou de ciência política. $\mathrm{O}$ grande debate deu-se entre os partidários da política da informática e aqueles que a identificam como um empecilho à política pública de desenvolvimento regional do pólo de Manaus.

Os parlamentares ligados a essa região brasileira tentaram interromper a continuação da política de informática por medidas provisórias, e buscaram inserir dispositivos na lei que na prática impediriam sua expansão nos pólos já consolidados de empresas, como a indústria paulista. Muito mais do que qualquer discussão sobre a conveniência da intervenção estatal no setor, foi a negociação política e as divergências com esses representantes que passaram a pautar os rumos posteriores da política e seus regramentos normativos.

A melhor evidência dessa alteração no debate é a forma pela qual se deu a segunda renovação da política em 2003. Embora seus resultados positivos e ampla adesão da indústria nacional tenham sido elementos de grande valia nesse processo, no limite foi o conflito com a ZFM que gerou a prorrogação até 2019. Foram os parlamentares defensores dessa política regional que, antevendo o término de seu prazo e a conseqüente diminuição 
de investimentos, iniciaram as negociações para sua continuidade e a inserção desse tema na reforma tributária iniciada no governo Lula da Silva, negociações essas que a seu fim deram origem ao artigo no ato das disposições constitucionais transitórias determinando a prorrogação da política de informática.

\section{c) Importância dos elementos liberalizantes para o setor}

Conforme já destacado, a abertura de mercado no governo Collor de Mello foi inicialmente concebida na PICE como uma estratégia política sustentada por dois grupos de medidas. O primeiro refere-se às medidas liberalizantes que constituem o cerne da abertura comercial (medidas de concorrência), incluindo o fim do protecionismo e a desregulação da economia, a fim de induzir a modernização da indústria via concorrência internacional. O segundo conjunto, no qual se encaixam o II PLANIN, a política de informática e a Lei 8.248/91, era composto de medidas para estimular o empresariado local (medidas de competitividade), incluindo redução dos custos de investimento (através de incentivos fiscais), redução dos custos de exportação e melhoria da infra-estrutura de ciência e tecnologia e recursos humanos. (CASSIOLATO E BAPTISTA, 1996, p. 61).

As ações de cunho liberalizante estão principalmente descritas e justificadas na PICE. Sua principal fundamentação é o esgotamento do anterior modelo de substituição de importações e utilização indiscriminada de instrumentos de proteção ao mercado interno. $\mathrm{Na}$ perspectiva do governo, esse padrão teria sido responsável por um parque industrial ineficiente e tecnologicamente atrasado, resultando em produtos de baixa qualidade e preços altos, além de empresas incapazes de atuar no mercado externo devido a sua baixa produtividade e potencial exportador.

Dentro desse contexto, a nova proposta era de um Estado menos interventor, que abandonasse ou reduzisse em larga escala tentativas de proteção a setores nacionais. $\mathrm{O}$ capital externo (na verdade qualquer capital) voltado a investimentos passaria a ser aceito e estimulado em quase todas as atividades (com reduzidas exceções estabelecidas constitucionalmente), incentivando a concorrência no mercado interno. Nos termos da PICE,

\footnotetext{
"a principal responsabilidade do Estado nesta fase do desenvolvimento industrial brasileiro é garantir a estabilização macroeconômica e a reconstrução de um ambiente favorável aos investimentos em geral [...]. Dedicado exclusivamente às suas funções básicas e recuperada sua capacidade de poupar, o Estado deixará de absorver o esforço de poupança nacional, abrindo espaço para que o capital
} 
privado exerça plenamente seu papel de principal agente do processo produtivo. [...] O investimento direto estrangeiro significará para o País, nesta nova etapa, importante fator na recuperação da taxa de investimento, na expansão do comércio internacional e no acesso à tecnologia. Neste aspecto específico será estimulado o maior envolvimento das empresas estrangeiras em atividades de pesquisa e desenvolvimento no País". (Portaria MEFP 365/90 - Diretrizes para a Política Industrial e de Comércio Exterior).

O desenvolvimento da informática no Brasil nos anos noventa, principalmente as repercussões da abertura ao mercado externo, confirmou a coerência e adequação de algumas dessas críticas de fundo teórico neoclássico. Essa afirmação não significa aceitação plena aos paradigmas e ditames dessa teoria, mas simplesmente o reconhecimento de que a concorrência internacional e o capital e tecnologia externos foram responsáveis por bons resultados à indústria nacional, ainda que se possa criticar severamente a forma pela qual essa abertura foi feita, e a inabilidade do governo federal em solucionar rapidamente algumas questões e pontos essenciais do novo paradigma político.

O fim do índice de nacionalização e a permissão quase irrestrita à operação de empresas estrangeiras de informática no país podem ter tido efeitos deletérios na balança comercial, mas esses fatores também têm boa parcela de responsabilidade pela modernização tecnológica e melhoria na qualidade dos bens disponíveis no país. Empresas estrangeiras, dentre outros motivos por apresentarem uma escala muito superior em seus negócios, aparentemente possuíam uma competitividade muito maior em sua produção. A partir da abertura essas empresas puderam comercializar no país, trazendo um novo fôlego ao mercado de informática brasileiro, sem que isso representasse uma queda no crescimento ao longo da década de noventa, como foi mostrado.

Uma evidência da discrepância entre empresas e produtos nacionais e estrangeiros é a recessão pela qual passou o setor brasileiro nos meses que antecederam a abertura. $\mathrm{O}$ mercado consumidor, ciente da superioridade tecnológica e competitividade dos preços no âmbito internacional, reduziu drasticamente o consumo, na expectativa de melhores negócios e equipamentos à disposição a partir de outubro de 1992.

O caso da década de noventa no setor de informática parece confirmar, dessa forma, parte do discurso de Roberto Campos e das críticas de viés neoclássico a políticas protecionistas não baseadas no sistema de preços de mercado. O desenvolvimento ulterior 
da indústria permitiu a seleção dos agentes que de fato tinham capacidade de concorrer ou que se uniram estrategicamente a parceiros institucionais que garantiram sua sobrevivência. Nesse novo cenário, a inovação tecnológica e a concorrência agressiva foram responsáveis por grandes ganhos de competitividade, resultando em melhorias no resultado final dos produtos ofertados.

Pode-se considerar um acerto da nova política de informática não retomar as medidas restritivas à concorrência e à entrada de novos ofertantes no período que se segue à antiga PNI. Procurar métodos alternativos que permitissem utilizar o incentivo e intervenção estatal sem desconsiderar os méritos e vantagens do livre mercado foi um aprendizado que trouxe bons frutos à indústria nacional e aos consumidores de equipamentos.

\section{d) Incentivo estatal e elementos neoschumpeterianos}

Não obstante as vantagens e benefícios advindos da abertura e dos elementos de cunho liberal da nova política, a década de noventa evidencia também a fragilidade da adoção de uma estratégia de política industrial baseada unicamente nesses elementos. Medidas de estímulo à inovação e competitividade foram importantes para a manutenção e modernização de uma base tecnológica local.

A importância em identificar e reconhecer na Lei de Informática elementos de origem evolucionária está em não visualizá-la como apenas uma renúncia fisscal do Estado, uma maneira alternativa de reduzir a carga tributária sobre o setor. Esta posição foi bem colocada e defendida pelo relator da Comissão de Desenvolvimento Econômico, Indústria e Comércio da Câmara dos Deputados, nos debates em 2004. O parlamentar, ao indagar qual seria a causa motivadora e justificativa para uma nova prorrogação da Lei de Informática, afirmou:

\footnotetext{
“a resposta a essa indagação reside em um fato óbvio e reconhecido: as alíquotas tributárias médias brasileiras não apenas no setor de informática, mas em vários outros setores, são muito elevadas. [...] Ou seja, chega-se à conclusão que a necessidade de prorrogação de regimes de exceção no país constitui mais um reflexo da excessiva onerosidade do sistema tributário que afeta o parque produtivo brasileiro. [...] Sendo assim, somos da opinião de que tais medidas são paliativos para uma reforma tributária ampla e consistente que, de fato, promova a redução das alíquotas vigentes no país. E para isso, é crucial que o
} 
governo reduza o seu nível de gastos de forma a preservar o equilíbrio das contas públicas". 58

Esta seria uma perspectiva restrita de análise da política, que não leva em conta alguns elementos cruciais identificados, como o estímulo aos esforços de pesquisa e desenvolvimento em empresas e universidades, a tentativa de manutenção de algum grau de agregação local de valor através do PPB e a redução do déficit setorial no comércio internacional.

Conforme identificado no item (a) acima, a Lei 8.248/91 é resultado de um acordo entre defensores de um projeto legislativo absolutamente liberal e uma proposta protecionista. Nesse sentido, embora especialmente as restrições de proteção à concorrência externa tenham sido excluídas neste consenso, elementos de intervenção estatal e estímulo e direcionamento empresarial foram mantidos.

São eles, principalmente, as reduções e isenções fiscais específicas para produtos produzidos conforme o plano de fabricação do governo (IPI), os incentivos semelhantes para pesquisa e investimentos nas empresas de informática (IR), as exigências de contrapartida em pesquisa, tanto interna quanto conjunta com universidades e centros de pesquisa, os fundos setoriais, e o próprio PPB. Dificilmente se pode considerar essas medidas como meras corretoras de falhas de mercado, ou geradoras de maior eficiência alocativa no sentido estático. Ao contrário, sob esse viés grande parte dessas medidas poderiam ser condenadas por sua ineficiência, ao alterar os sinais e custos de oportunidade do sistema de preços de mercado, fazendo com que os agentes menos competitivos obtenham maiores lucros por uma discriminação tributária, ou direcionando a utilização de recursos para atividades (contrapartida em pesquisa e desenvolvimento, aquisição de participação societária em empresas de informática com isenção fiscal) que poderiam não trazer o melhor retorno do investimento realizado.

Assim, sua importância e resultados somente podem ser reconhecidos se essas ações são vistas como geradoras de eficiência em termos sistêmicos e competitividade empresarial ao longo do tempo. Sob essa perspectiva, espera-se que as empresas de informática que aderiram à política utilizem os incentivos para garantir sua sobrevivência

\footnotetext{
${ }^{58}$ Relatório da Comissão de Desenvolvimento Econômico, Indústria e Comércio ao Projeto de Lei 3.015/04, grifos nossos.
} 
estimulando a inovação tecnológica, com externalidades positivas que viriam a beneficiar economicamente o país.

Encaradas sob esse prisma, a política de informática trouxe resultados vantajosos. O aumento nos dispêndios e o montante de recursos destinados pelo setor a pesquisa e desenvolvimento, que havia caído drasticamente no início da década de noventa, já é um dado a ser comemorado. Independente das críticas a essas atividades, elas representam um investimento das empresas para melhoria e desenvolvimento de novos produtos e processos, assim como a possibilidade de aprimoramento de recursos humanos. As apresentações realizadas pelas universidades e centros de pesquisa no primeiro seminário de resultados da Lei de Informática atestam a importância desses recursos para projetos dessas instituições, recursos que constituem uma força para a integração universidadeempresa, que é uma deficiência da maioria dos cursos de graduação e pós-graduação brasileiros.

Conforme visto, embora não se possa atribuir à política de informática responsabilidade plena pelo expressivo crescimento do setor e redução significativa dos preços na década de noventa, é razoável afirmar que ela deu sua contribuição para este cenário (especialmente no caso da redução de preços com a redução fiscal). Esta contribuição deu-se não apenas em função das reduções fiscais, mas principalmente pela arquitetura de incentivos que fez com que empresários, nacionais e estrangeiros, preservassem no país a parcela final do processo de montagem dos equipamentos, incentivando, ainda que em menor grau, as empresas a manterem suas instalações no território nacional.

Esta seria uma forma de tentar obter eficiência e competitividade no longo prazo. Além disso, ao alterar o cálculo empresarial nesse sentido, a política de informática obteve uma redução no peso do setor eletro-eletrônico no déficit da balança comercial brasileira, podendo esse fato ser lido como uma tentativa do setor público de melhor inserção do país no mercado internacional. Esses elementos, como se nota, são muito próprios de uma abordagem neoschumpeteriana.

Assim, parece haver na narrativa e exposição realizadas evidências suficientes para o argumento de que a Lei de Informática e a política que ela embasa se baseiam tanto em 
elementos provenientes de uma racionalidade econômica neoclássica quanto neoschumpeteriana. Ambos foram fundamentais para os sucessos atingidos pela política durante esse período.

Por outro lado, o discurso altamente positivo e otimista proferido pelo governo federal deve ser visto com cautela, principalmente porque: parcela dos ditos resultados da política são na verdade um reflexo do bom momento pelo qual passou esse setor nos últimos anos; esse discurso não parece dar o devido crédito à herança recebida de um período no qual muito se fez em matéria de informática no Brasil; além disso, a política foi incapaz de solucionar problemas estruturais da indústria brasileira, principalmente a geração de escala e tecnologia que permitissem a instalação de uma indústria nacional de componentes e semicondutores.

No próximo capítulo realizarei a análise de alguns pontos específicos da política de informática nacional, que permitirão aprofundar a compreensão dos problemas e sucessos que embasam essa avaliação formulada, que acredito estar coerente com o histórico e conjunto de indicadores aqui apresentados. 


\section{CAPÍTULO 4. TEMAS E INSTRUMENTOS JURÍDICOS RELEVANTES DA POLÍTICA DE INFORMÁTICA}

A leitura sobre a evolução da política de informática realizada no capítulo anterior exigia uma exposição relativamente linear de seus fatos e eventos, a fim de que fosse possível extrair conclusões gerais sobre o processo de sua formulação, implementação e revisão ao longo do tempo. Para isso, foi necessário não adentrar profundamente em alguns tópicos e instrumentos jurídicos da política que, não obstante sejam de grande importância, não poderiam ser tratados adequadamente no mencionado capítulo, sob pena de inviabilizar a reconstrução histórica.

Este capítulo tem o objetivo de suprir a lacuna gerada pela opção metodológica adotada e, sobretudo, explicitar a dimensão jurídica do assunto desta dissertação. Irei aqui aprofundar o estudo de três temas que podem ser tidos como pilares da política em seu momento atual. O primeiro retoma como, através de um instrumento jurídico, a política de informática pretendeu (e sob muitos aspectos obteve êxito em) alterar e direcionar a produção de máquinas e equipamentos eletrônicos no Brasil, inibindo a importação de bens finais e incentivando a agregação de valor pelas empresas em território nacional.

Os dois temas seguintes tratam do incentivo $\mathrm{e}$ fomento à pesquisa $\mathrm{e}$ desenvolvimento. Tratarei primeiramente da pesquisa empresarial interna exigida pela lei, e de como as empresas vêm cumprindo esse requisito, os resultados gerados e seus problemas. Por fim, também será abordado o fundo setorial CT-Info, instituído em 2001 e gerido pelo governo federal para financiar projetos e programas de inovação de empresas, universidades e centros de pesquisa do setor de informática.

Parto da premissa de que as dinâmicas política e econômica que geraram e determinaram a evolução desses instrumentos já foram em grande parte aclaradas nos capítulos pregressos. Aqui, portanto, será adotada uma abordagem mais voltada ao campo jurídico, buscando compreender como se tentou, através do direito, estimular o mercado ou atacar determinados problemas considerados entraves ao desenvolvimento do setor, dentro do contexto de uma política setorial. 
A pergunta principal a ser respondida aqui é: quais são e como foram estruturados juridicamente os instrumentos utilizados na política de informática para, de alguma forma, moldar ou alterar a conduta ou estratégia dos agentes privados? Em outras palavras, de que conjunto normativo de incentivos e obrigações lançou mão o governo federal para levar (ou tentar levar) as empresas a trilhar determinadas opções de negócio ou seguirem determinadas regras?

A hipótese considerada é que se trata de uma política pública que não pode ser compreendida como medidas ou ações de Estado individualmente consideradas, abrangendo, na verdade, um agrupamento de instrumentos relacionados entre si e que encontram sua lógica e sentido no conjunto.

Estas ferramentas apresentam características e maneiras distintas para solucionar determinados problemas. Nas próximas seções, buscarei analisar suas peculiaridades, para compreendê-las com maior propriedade. Alguns critérios deverão nortear essa análise e ser especialmente ressaltados, por serem considerados importantes para um exame jurídico e por permitirem uma avaliação comparativa desses instrumentos ao final deste capítulo.

Os critérios de análise jurídica são: (i) o problema a ser enfrentado, ou a razão de criação da ferramenta em questão; (ii) a racionalidade adotada para enfrentar o problema identificado; (iii) como pode ser descrita ou caracterizada a função cumprida pelo direito e pela estrutura jurídica dentro dessa racionalidade; (iv) o principal núcleo normativo que materializa e descreve o instrumento, isto é, se ele já se encontra suficientemente explicitado na lei ou se, ao contrário, a sua compreensão depende de regras estabelecidas em outro ato normativo infra-legal; (v) como se deu, ou quais as características da evolução do arcabouço normativo referente a essa ferramenta ao longo do tempo; (vi) quais os sucessos e bons resultados advindos de sua adoção; e, por fim, (vii) os limites e problemas enfrentados, com ênfase em questões institucionais e jurídicas.

Quanto a este último critério (limites e problemas), a escolha dos três temas aqui abordados se revela de grande importância. Através desses exemplos, argumentarei que os problemas enfrentados pela política de informática ao longo de seu percurso podem advir de distintas fontes, sendo que apenas parte deles pode ser solucionada exclusivamente 
através desta política setorial, havendo assim limites de sua efetividade. Ao final, será feito um esforço para responder até que ponto, neste caso concreto (sem pretensões de generalização), o arcabouço institucional e jurídico foi capaz de apontar direções e atuar de maneira colaborativa com o setor privado, assim como os principais pontos problemáticos neste processo de construção de uma política setorial.

\subsection{O Plano Produtivo Básico (PPB)}

Conforme descrito no capítulo anterior, a lógica da política instituída pela Lei 8.248/91 não é a de um incentivo físcal amplo e irrestrito a todas as empresas do setor, para aumento da competitividade apenas pela redução de preços. Ao contrário, a política estabelece uma via de reciprocidade, em que as empresas obtêm benefícios sob a condição de aderir e cumprir com uma série de obrigações que condicionam sua participação.

A isenção fiscal, portanto, nunca foi automática ${ }^{1}$, e por isso sua fruição depende de uma requisição formal ao governo, na qual a empresa descreve o seu projeto de produção e investimento em tecnologia, comprovando sua adequação à regulamentação da política. $\mathrm{O}$ pleito é analisado pelos órgãos responsáveis e, se favorável, uma Portaria Conjunta do MCT e do MDIC é expedida trazendo menção expressa à empresa e aos produtos incentivados. Seguindo uma linha já adotada na política anterior, uma das obrigações a serem cumpridas se refere à produção dos produtos incentivados.

Dentro do quadro de critérios de análise que estabeleci, o problema a ser atacado por essa medida seria a perda ou não manutenção do parque fabril instalado no período anterior, devido à sua fragilidade ou pouca competitividade face aos equipamentos de competidores estrangeiros que começaram a chegar ao país com o fim da reserva de mercado. Como identificado no capítulo anterior, a indústria de componentes em sua quase totalidade não resistiu a essa mudança de paradigma (abertura do mercado interno), e mesmo as empresas de equipamentos finais já alteravam suas estratégias de negócios, abandonando o modelo de desenvolvimento autônomo para se unirem a fabricantes internacionais através das joint-ventures e outros acordos comerciais. Dentro da visão da política pública adotada nesse período (a proposta vencedora no Congresso Nacional - a versão reformada do substitutivo Luiz Henrique) estes fenômenos eram conseqüências

\footnotetext{
${ }^{1}$ Não estou considerando a redução de IPI realizada pelo governo federal através de Decreto 3.686/00 - ver seção 3.6 do capítulo 3 .
} 
negativas da abertura, que deveriam ser amenizadas através de uma postura intervencionista e não neutra.

Foi assim estabelecido que, para usufruírem dos benefícios fiscais da política, as empresas deveriam cumprir com um mínimo de etapas produtivas. Esse conjunto mínimo, ou "nível de valor agregado local" (nos termos da Lei 8.248/91), foi intitulado Plano Produtivo Básico - PPB. Mais do que uma mera indicação abstrata e genérica, o PPB é na verdade uma descrição minuciosa e específica para cada produto. Isso significa que uma empresa apenas poderá requerer o benefício fiscal para um produto baseado na Lei de Informática se o governo houver previamente expedido uma portaria determinando o PPB para aquele bem, as etapas produtivas exigidas e outros requisitos.

A racionalidade proposta por esta ferramenta jurídica baseada em estímulos econômicos (e não na imposição de uma sanção jurídica) é, portanto, a de garantir uma redução da carga tributária se, por outro lado, os agentes econômicos concordarem em realizar determinadas etapas do processo produtivo. Através desta contrapartida se pretendeu assegurar que as empresas mantivessem alguma capacitação e produção local (e empregos), evitando que se tornassem puras revendas ou distribuidoras de produtos importados. O direito aparece aqui tendo um efeito que poderia ser descrito como instrumental e indutor, na medida em que busca direcionar o comportamento privado para cumprir as finalidades da política pública através da premiação.

Em conversas informais realizadas durante a elaboração desta dissertação com empresários do setor e membros de associações representativas das empresas, foi mencionado que havia um projeto para que o PPB fosse na verdade um instrumento dinâmico que acompanhasse a evolução do setor. Dentro dessa lógica, as primeiras normas descreveriam apenas um conjunto de exigências mínimas, que seriam ampliadas à medida que as empresas estabelecidas localmente ganhassem maior capacitação tecnológica e pudessem abarcar atividades de maior agregação de valor. Se verdadeiro, isto certamente representaria uma racionalidade mais elaborada para esta política pública, uma vez que tenta ampliar seus resultados e incrementar a produção local. Não localizei, entretanto, qualquer fonte publicada que confirmasse esse plano, e os debates parlamentares da aprovação da primeira lei na Câmara dos Deputados não fornecem qualquer evidência para confirmar esta hipótese. Além disso, o desenvolvimento posterior da política não caminhou 
neste sentido, e ao longo dos anos houve uma tendência de flexibilização, ao invés de maior rigidez, do PPB.

Ainda assim, a política tem no PPB um instrumento de grande potencial regulador da atividade econômica privada. As portarias que descrevem as atividades produtivas afetam e direcionam diretamente o cálculo e as estratégias de negócios empresariais. Ao exigir produção interna das empresas ou utilização de componentes produzidos no território nacional, elas em última instância alteram os estímulos e sistemas de preços de mercado, na medida em que influenciam nas decisões de make-or-buy das empresas (produção interna de componentes e periféricos contra sua aquisição de um fornecedor), e nas escolhas de seus parceiros comerciais. As firmas beneficiadas têm que adequar sua produção e projetos às determinações do poder público, em um modelo tipicamente regulatório. As empresas estrangeiras, em especial, devem cumprir esses requisitos, em um esquema que com grande probabilidade pode destoar de seu planejamento global da produção, usualmente dividida entre filiais e fornecedores localizados em diversas partes do globo ${ }^{2}$.

Percebe-se aqui, por isso, uma discrepância entre a retórica neoliberal predominante no início dos anos noventa e a política de informática efetivamente implementada nesta mesma década em diante no Brasil. Conforme identificado no primeiro capítulo, uma das principais características do ideário neoliberal é sua crença no sistema de preços ( "get the prices right"), e a intervenção estatal da política "manipula" ou "distorce" esse sistema, seja direta (no mercado de insumos e componentes) ou indiretamente (ao trazer impacto ao preço final dos bens e equipamentos para consumo). Esta tentativa de regulação da atividade produtiva por parte do poder público não é condizente com o discurso de otimalidade paretiana, concorrência perfeita e vantagens comparativas proposto pela teoria

\footnotetext{
${ }^{2}$ Faria identificou esse processo de organização empresarial em escala global como uma resposta à crise econômica dos anos 70 viabilizada pelas inovações tecnológicas no transporte e comunicações. "Deflagrando um abrangente e veloz processo de reengenharia operacional, logística, técnica e acionária, as novas estratégias de racionalização organizacional, decisória e produtiva levaram as empresas a promover, em amplitude transnacional, um sem-número de unidades produtivas até então autônomas [...]. A companhia global ou corporação transnacional tende a se organizar por meio de unidades ou divisões empresariais. Elas são altamente flexíveis, modulares e, acima de tudo, articuladas em perspectiva reticular. Deste modo, a atuação e o desempenho das corporações transnacionais ou companhias globais não configuram mais um agregado de atividades em nível de países, sob a forma de estruturas burocráticas e organizacionais estáveis e rígidas. Pelo contrário, passam a ter a forma de um sistema de negócios desagregado, administrado como um processo interligado, controlado por informações compartilhadas e organizado horizontalmente por assunto, produto ou serviço". (FARIA, 1999, pp. 70-72).
} 
neoclássica, o que confirma a afirmação de Cassiolato e Baptista de que a abertura comercial promovida pelo governo Collor de Mello constituía-se na verdade de um movimento conjunto de medidas de liberalização e desregulação da economia com ações de ganho de competitividade de viés neoschumpeteriano. (CASSIOLATO E BAPTISTA, 1996, p. 61). A continuidade da utilização deste instrumento e as sucessivas renovações da política ao longo do tempo, no entanto, parecem contestar a idéia dos autores de que as medidas neoschumpeterianas teriam sido completamente frustradas ("Por fim, apenas a agenda neo-liberal está sendo implementada" - CASSIOLATO E BAPTISTA, 1996, p. 61, tradução nossa $\left.{ }^{3}\right)$.

O PPB é um instrumento de política pública calcado em cinco níveis de normas jurídicas, conforme abaixo:

1) Seu embasamento constitucional pode ser extraído dos seguintes artigos da Constituição Federal de 1988: 218, segundo o qual o Estado deverá promover e incentivar o desenvolvimento científico e a capacitação tecnológica, e 219, que determina o incentivo do mercado interno para viabilizar, dentre outros objetivos, a autonomia tecnológica do país, em uma linguagem e conjunto de valores claramente mais conectados com a antiga política nacional de informática da década de oitenta.

2) A Lei de Informática (e suas alterações posteriores), que apenas cita de maneira não detalhada o PPB ou o requisito de agregação de valor local, deixando sua explicitação a cargo das normas infra-legais.

3) A lei e suas obrigações são explicitadas em um decreto de regulamentação, que estabelece os procedimentos e condições para a fixação de um PPB e aprovação de projetos empresariais nele baseados.

4) Do ponto de vista jurídico-procedimental, a partir daí a empresa interessada pode solicitar ao MCT a discriminação do PPB, que o aprova através de uma portaria conjunta do MCT e do MDIC.

\footnotetext{
3 "Eventually, only the neo-liberal agenda is being implemented". (CASSIOLATO E BAPTISTA, 1996, p.
} $61)$. 
5) Ainda desde uma ótica procedimental, a empresa submete um novo requerimento ao MCT, com seu projeto de pesquisa e desenvolvimento específico, e compromisso de adequação ao PPB, o que é outorgado mediante nova portaria.

Analisando esse arcabouço normativo e sua evolução, me pareceu claro que a concretização da política é realizada principalmente pelas portarias interministeriais (item 4 acima). A especificidade e os detalhes técnicos de equipamentos de informática fazem com que a lei e o decreto possam apenas estabelecer indicadores imprecisos sobre o PPB. Sua efetivação somente se dá através das referidas portarias expedidas pelos burocratas, que têm o conhecimento técnico necessário e podem formular essas normas consoante sua interpretação da política ou outros interesses. Isto é evidenciado pela larga produção normativa da burocracia dos ministérios desde 1993, determinando o PPB para as famílias de produtos aplicáveis.

Há, nesse sentido, uma assimetria informacional em favor da burocracia, o que, conforme levantado pela literatura de falhas de governo, é um problema a ser enfrentado na formulação e implementação de políticas públicas. É difícil, entretanto, identificar com precisão como, neste caso, este problema de informação imperfeita afetou e vem afetando a política de informática. Apesar da especificidade, uma rápida revisão das portarias que instituíram os PPBs registra que a maioria delas possui termos padronizados e faz referência a processos produtivos muito similares, independente dos bens ("montagem e soldagem de componentes”, “integração das placas” - PORTARIA MCT/MICT 101/93). Especialmente após o primeiro momento, quando se podem identificar algumas atividades adicionais, as descrições dos PPBs revelam-se de fato bastante similares.

Ainda que o PPB e a política não tenham concretizado os objetivos de autonomia tecnológica típicos da década de oitenta e impressos na Constituição Federal, esta medida apresentou seus resultados, e seu arcabouço jurídico demonstrou uma interessante dinâmica evolutiva. Há períodos específicos em que as normas apresentaram uma maior preocupação com determinado elemento ou problema, e se pode identificar uma evolução significativa no grau de complexidade em sua elaboração. Particularmente no nível legal e regulamentar, há uma grande diferença entre as primeiras normas (Lei 8.248/91 e Decreto 792/93), que sequer faziam referência expressa ao PPB, até a atual versão (Lei 11.077/04 e 
Decreto 5.906/06), com uma descrição minuciosa e tentativa de solução de problemas e entraves gerados e identificados no bojo da implementação da política ao longo dos anos.

A tabela abaixo indica as principais normas e tenta situá-las no tempo dentro de um determinado contexto evolutivo. Minha idéia não foi tentar estabelecer uma classificação exaustiva, mas apenas esboçar uma apresentação da evolução jurídica do PPB enquanto ferramenta da política de informática. Tento mostrar que as Leis 10.176/01 e 11.077/04 não foram puras reproduções ou renovações do mesmo arcabouço institucional, mas apresentaram alguma novidade com relação ao momento anterior - e por esse motivo a divisão aqui feita está baseada na edição de cada uma das três principais leis sobre o assunto. Faço a seguir uma breve explicação sobre cada um desses períodos ou ciclos mencionados.

\begin{tabular}{|c|c|c|c|}
\hline & $1^{\circ}$ Ciclo & $2^{\circ}$ ciclo & $3^{\circ}$ ciclo \\
\hline Lei & $8.248 / 91$ & $10.176 / 01$ & $11.077 / 04$ \\
\hline $\begin{array}{l}\text { Decreto de } \\
\text { regulamentação }\end{array}$ & $792 / 93$ & $3.800 / 01$ & $5.906 / 06$ \\
\hline $\begin{array}{l}\text { Principais } \\
\text { portarias PPB }\end{array}$ & MCT/MICT 101/93 & $\begin{array}{c}\text { MDIC/MCT 90/01 } \\
\text { MDIC/MCT 253/01 } \\
\text { MDIC/MCT 177/02 }\end{array}$ & MDIC/MCT 148/07 \\
\hline $\begin{array}{l}\text { Características } \\
\text { jurídicas } \\
\text { principais }\end{array}$ & $\begin{array}{l}\text { Construção do arcabouço } \\
\text { regulatório. } \\
\text { Legislação ampla e não } \\
\text { precisa. } \\
\text { Grande espaço normativo para } \\
\text { instrumentos infra-legais. } \\
\text { Ainda ligado a idéias e temas } \\
\text { da política anterior. } \\
\text { Fase de teste e adaptação do } \\
\text { PPB (portarias que excluem } \\
\text { obrigações anteriormente } \\
\text { estabelecidas ou as suspendem } \\
\text { por determinado tempo). }\end{array}$ & $\begin{array}{l}\text { Consolidação, especia- } \\
\text { lização e detalhamento da } \\
\text { legislação - incorpora } \\
\text { aprendizado do } 1^{\circ} \text { ciclo. } \\
\text { Criação de órgão específico } \\
\text { para análise do PPB, e de } \\
\text { prazos e procedimentos. } \\
\text { Admite terceirização no } \\
\text { PPB (generalização da } \\
\text { permissão). }\end{array}$ & $\begin{array}{l}\text { Consolidação } \\
\text { legislação anterior } \\
\text { poucas alterações. } \\
\text { Foco em solucionar } \\
\text { questões e problemas } \\
\text { trazidos, mantendo a } \\
\text { estrutura original: } \\
\text { sanções para não } \\
\text { investimento em P\&D; } \\
\text { celeridade na análise dos } \\
\text { pedidos de benefícios. }\end{array}$ \\
\hline
\end{tabular}

O primeiro momento foi o da construção e dos primeiros anos da política. A legislação aqui apresentava um grau de refinamento ou minúcia muito inferior às normas posteriores. A Lei 8.248/91 não fazia referência explícita ao PPB, mencionando apenas que seriam beneficiados os produtos com "níveis de valor agregado local compatíveis com as características de cada produto", conforme aprovado pelo Poder Executivo por proposta do CONIN. O decreto determinou que caberia ao MCT e ao então Ministério da Fazenda a responsabilidade por expedir uma portaria conjunta fixando os produtos beneficiados. Esta divisão de competências parece fazer bastante sentido se considerada a conjuntura política 
do início dos anos noventa, na qual o MEFP, dotado de prestígio e força no governo Collor de Mello, tinha uma postura de receio quanto à política de informática. Ao manter o controle sobre os PPBs fixados, este órgão poderia garantir que a política industrial traçada fosse seguida pela burocracia do MCT, evitando exigências excessivamente rígidas e que limitassem a concorrência no ato de concretização da política.

Após a regulamentação em 1993, diversas portarias passaram a ser expedidas, estabelecendo o PPB para equipamentos e produtos finais de informática. Não é o caso de descrever ou mencionar todas elas, mas cabe mencionar que neste primeiro momento algumas das obrigações impostas às empresas parecem mais conectadas à ideologia intervencionista e desenvolvimentista dos anos oitenta do que ao viés liberal da década seguinte. Parte dessas obrigações realmente estava embasada nas determinações da lei, como a exigência de capacitação do corpo técnico da empresa, os programas sucessivos de exportação e a exigência de obtenção de certificações de qualidade (esta última uma obrigação que remanesce e se mostrou frutífera).

Em outros aspectos, entretanto, os ministérios podem ter inovado consideravelmente a ordem jurídica, ultrapassando os limites da lei, ao exigir das empresas atividades de engenharia destinadas à fabricação do produto, inclusive com submissão ao MCT de termos de transferência de tecnologia, que deveriam contemplar "a transmissão dos conhecimentos necessários à plena operação industrial na fabricação desses produtos" e "um programa detalhado de treinamento de pessoal e de nacionalização das atividades de engenharia, compatível com o domínio da tecnologia" (Portarias Interministeriais MICT/MCT/MC 273/93 - informática aplicada a telecomunicações, e 135/94 - fibras ópticas). Esses tipos de requisitos foram posteriormente abandonados e deixaram de fazer parte das descrições dos PPBs mais recentes.

A continuidade da política após o seu prazo inicial de vigência em 2001 permitiu um aperfeiçoamento das normas, havendo a incorporação de lições aprendidas nos primeiros anos, e uma maior especificação para resolução de problemas e atenção à realidade econômica e produtiva do setor. A diferença começa já no plano legal - a Lei 10.176/01 passou a se referir expressamente ao PPB (abandonando a terminologia "nível de agregação de valor"), determinando também um prazo máximo de 120 dias para que o MCT e o MDIC apreciassem as solicitações das empresas a esse respeito, tentando assim 
solucionar o problema da delonga na fixação dos planos. Para o cumprimento deste prazo, o Decreto 3.800/01 instituiu o Grupo Técnico Interministerial de Análise de PPB, composto por representantes do MDIC e do MCT, e responsável por examinar, emitir parecer e propor a fixação, alteração ou suspensão de etapas dos PPB.

Um ponto relevante nesta segunda fase foi o reconhecimento e regulação da terceirização produtiva para efeitos da política. Apesar de se tratar de uma realidade para a grande maioria dos setores econômicos industrializados, o outsorcing ou terceirização de tarefas é muito importante e amplamente utilizada pelas empresas de informática. Conforme Araújo, a indústria de hardware foi profundamente afetada no período recente por este processo, passando de uma estrutura industrial de grandes empresas verticalizadas para uma grande especialização vertical e horizontal numa cadeia dispersa geograficamente. Trata-se de um fenômeno conhecido por modularização, que permitiu a fragmentação da cadeia produtiva. $\mathrm{O}$ trabalho passou a ser pensado e dividido em projetos (modularidade técnica), criando novas oportunidades para a sua organização. O outsorcing pode ser feito de maneira integral (incluindo a totalidade da etapa de um projeto) ou apenas de forma pontual, envolvendo uma atividade ou fabricação de componente específico. (ARAÚJO, 83-86). Segundo Araújo:

\footnotetext{
"Essa estrutura permite às empresas realizar outsorcing pontual de suas funções ao longo da cadeia de valor, possibilitando que mantenham o foco nas suas competências essenciais (core competencies), em que possuem maiores margens de lucro e não podem ser externalizadas para manter a vantagem competitiva da firma. Inicialmente, essa externalização se restringia às tarefas secundárias, especialmente da manufatura. Hoje, ela está presente em todos os níveis da cadeia, inclusive naqueles relacionados com pesquisa e desenvolvimento." (ARAUJO, P. 82-83).
}

Sendo assim um procedimento tão habitual no setor e um requisito para competitividade das firmas, seria uma incongruência que a terceirização se tornasse um óbice para obtenção dos benefícios físcais da Lei de Informática. Era de grande importância, portanto, que a empresa beneficiada pela política pudesse subcontratar sua produção (ou parte dela) sem perder os incentivos, ou seja, o cumprimento do PPB não poderia significar que a empresa adotasse uma estrutura organizacional centralizadora e vertical, que abarcasse a execução de todas as etapas produtivas exigidas. 
As primeiras normas e portarias não tratavam deste assunto, e este foi um aprendizado ocorrido ao longo dos primeiros anos de vigência da política. Assim, mesmo antes da renovação da lei em 2001, as portarias de PPB mais recentes já passaram a autorizar as empresas a realizar a contratação. A generalização do procedimento para todos os produtos e bens, no entanto, só vai ocorrer em meados de 2001, quando a Portaria MDIC/MCT 90/2001 consolida os PPBs então vigentes, e determina que "qualquer etapa dos Processos Produtivos Básicos poderá ser terceirizada”. Em 2003 um novo decreto (4.944/03) descreveu mais minuciosamente esta relação. Esta norma permite que a empresa contratante - que pode ser considerada a responsável pela integralidade do projeto (ou de uma parcela deste) - assuma as obrigações de investimento em pesquisa e desenvolvimento de suas contratadas, nos limites do faturamento com a venda dos bens solicitados à contratante. Seguindo esta regra e procedimento, os bens desenvolvidos ou vendidos pelas contratadas poderão se beneficiar da isenção de IPI ${ }^{4}$.

Sob a perspectiva jurídica, este tema da regulação das práticas de terceirização demonstra a importância da existência de uma fina sintonia entre uma política setorial e a realidade do setor que ela afeta. Tratando-se de uma prática difundida no setor de informática nos anos noventa, fez-se muito importante que o arcabouço normativo respondesse a essa evolução, sob pena de gerar incentivos e resultados não adequados à política, além de afetar injustificadamente os preços finais devido à proibição do outsorcing. Isto retoma o argumento de informação imperfeita da literatura de falhas de governo, no sentido de que a implantação de uma política pública adequada demanda a obtenção e processamento de um grande volume de dados, o que neste caso se soma à necessidade de uma intensa atualização devido à dinâmica tecnológica da indústria de TI.

Seria impróprio, todavia, afirmar que esta assimetria informacional inviabilizou a política, ou tornou seu custo "proibitivo", como pretendem os formuladores dessa teoria 5 . Aqui, a burocracia do MCT pôde realizar esta mudança sem maiores entraves ou procedimentos, uma vez que não dependia do poder legislativo para a aprovação de uma nova lei. Isto revela a importância da "margem de manobra" ou do conteúdo normativo

\footnotetext{
${ }^{4}$ Noto que esta transferência de obrigações não é completa, tornando-se na verdade um elemento de risco para as empresas terceirizadas. Conforme o decreto, caso a empresa contratante não cumpra com as obrigações de pesquisa assumidas, a contratada estará sujeita às penalidades da lei. E considerando a incerteza e o tempo que o MCT tomava, especialmente no início desta década, para aprovar os relatórios de dispêndios em pesquisa, este risco não pode ser considerado desprezível.

${ }^{5}$ Conforme seção 1.3 acima.
} 
não preenchido pela Lei de Informática ou mesmo pelo decreto de regulamentação, deixado para ser definido pela burocracia mais próxima do setor e da implementação da política. Aparentemente, o fato de o que chamei de núcleo normativo que concretiza o PPB estar em nível infra-legal em poder dos órgãos públicos do Poder Executivo envolvidos foi de grande importância para a incorporação do aprendizado ${ }^{6}$.

Por fim, o terceiro ciclo de normas realiza uma maior sistematização no tratamento da matéria. O Decreto 5.906/06 traz pela primeira vez um dispositivo que define o PPB "o conjunto mínimo de operações, no estabelecimento fabril, que caracteriza a efetiva industrialização de determinado produto" (art. 16). Não há, entretanto, alterações normativas significativas na segunda renovação da Lei de Informática. Pode-se afirmar que este último ciclo representou uma consolidação do arcabouço institucional da política, havendo a manutenção da grande maioria das regras e procedimentos, com uma preocupação na correção de matérias e problemas reivindicados pela indústria, como a delonga na aprovação das solicitações de benefícios das empresas. Foi instituído, neste sentido, mais um órgão para dar celeridade a esse processo, a Câmara Técnica Interministerial para Pleitos de Concessão - CTI-PC (Portaria MCT/MDIC/MF 148/07).

Como novidade da Lei 11.077/04 e sua regulamentação no tema do PPB e incentivos ressalto a instituição de um benefício fiscal maior para produtos desenvolvidos no país. Conforme discutido no capítulo anterior, esta alteração tem por objetivo não uma reconstrução da política nacionalista dos anos oitenta, mas uma proposta que tenta se aproveitar do cenário internacionalizado de pesquisa e desenvolvimento no setor de informática para tentar trazer ao país centros e projetos de pesquisa de empresas multinacionais.

Os resultados e as críticas levantadas contra a opção política pelo PPB e sua estrutura foram anteriormente mencionados, mas podem agora ser retomados à luz desta revisão da legislação. Conforme apontado por um estudo do BNDES, ainda que, originalmente, a adoção do PPB tenha servido para a manutenção/instalação de montadoras de produtos finais no país diante da abertura comercial (o que pode ser enquadrado como

\footnotetext{
${ }^{6}$ Embora este fato também levante o questionamento sobre a captura da política pelo setor privado, problema acerca do qual não encontrei qualquer literatura ou menção a respeito neste caso.
} 
sucesso ou bom resultado da ferramenta), suas definições, nos termos atuais, foram frágeis para garantir níveis expressivos de agregação de valor. (MELO, 1999, p. 272).

O impacto (ou ausência de impacto) maior da estrutura da política consubstanciada no PPB se deu na cadeia produtiva das empresas do setor. Conforme Baptista, a extinção do conceito ou critério jurídico adotado anteriormente (o índice de nacionalização) implicou uma reorientação estratégica das empresas. Estas, em sua ampla maioria, interromperam o desenvolvimento e produção de partes e componentes, passando a adquirí-los de fornecedores internacionais, o que reduzia os seus custos. Nesse sentido, o PPB poderia representar um contrapeso a esta tendência. Só que, como a maioria das Portarias fez referência apenas à montagem e soldagem de bens, com pouca produção local efetiva, a indústria sobrevivente e a instalada após o início da política acabou se adequando a esse modelo, sendo este o grande problema ou limite deste instrumento da política. "A atual [a autora refere-se à década de noventa] política de informática não oferece qualquer mecanismo que se contraponha à desagregação industrial fruto da imposição da lógica do mercado". (BAPTISTA, 1997).

No mesmo sentido também pensam Garcia e Roselino. As empresas estabelecidas no Brasil nos anos noventa não tiveram problemas em cumprir os requisitos mínimos exigidos pelo MCT para a obtenção dos benefícios. Bastava que realizassem a montagem das placas e dos equipamentos para atender às necessidades de internalização da produção, e na visão dos autores isso seria um indicativo da inadequação deste instrumento de incentivos públicos (GARCIA E ROSELINO, p. 182). Eles argumentam que o PPB não tem sido um método suficiente para internalizar partes mais relevantes da cadeia produtiva:

\footnotetext{
"A inexistência de obrigações relativas a internalização de etapas produtivas mais densas nas cadeias de valor acaba restringindo os efeitos da Lei de Informática à potencialização de capacitações internas, geração de empregos qualificados (notadamente engenheiros empregados nos departamentos de P\&D) e demais efeitos de transbordamento". (GARCIA E ROSELINO, p. 183).
}

Acredito, contudo, que seja importante amenizar em parte essas críticas. Especialmente sob a perspectiva jurídica, entendo que seja difícil atribuir a maior parte dos ditos fracassos do PPB ao desenho institucional ou normativo da política. Tal desenho pareceu representar bem as decisões políticas tomadas e, no âmbito da racionalidade exposta, os resultados foram atingidos. 
Há aqui, na verdade, uma escolha feita para o mercado de equipamentos de informática no país, qual seja a abertura e concorrência internacional, que não pode ser desconsiderada. Conforme já mencionado na seção 3.9 do capítulo anterior, o desmonte de grande parte da produção nacional (especialmente de componentes e periféricos) foi um resultado desse processo. A partir do momento em que o país entrou no mercado internacional desses bens, surgem ou são potencializados diversos problemas para a manutenção dessa indústria, como a ausência de escala da indústria doméstica. Problemas estes que não podem ser resolvidos exclusivamente com base no PPB ou mesmo nos demais instrumentos da política.

Não se trata, portanto, de fazer uma condenação absoluta da forma como foi estruturado o PPB. Na verdade este instrumento tem vantagens e trouxe alguns resultados expressivos. A introdução do PPB na racionalidade empresarial conseguiu limitar o movimento de desconstrução da indústria no que se refere aos produtos finais. Ainda que essas indústrias realizem apenas o CKD (complete knock-down) no país, a manutenção deste estágio de agregação de valor localmente pode ser atribuída em grande parte ao PPB. Conforme já mencionado, a hipótese de Baptista a esse respeito é de que na ausência deste instrumento e dos incentivos da lei haveria uma intensificação da tendência de substituição de produção local por importações. (BAPTISTA, 1997).

Por fim, um último problema a ser mencionado é a centralização ou ausência de regionalização dos incentivos da lei. Conforme dados coletados na página do Ministério da Ciência e Tecnologia, em meados de 2007 havia 382 empresas cadastradas para benefícios da Lei de Informática, localizadas conforme abaixo: 

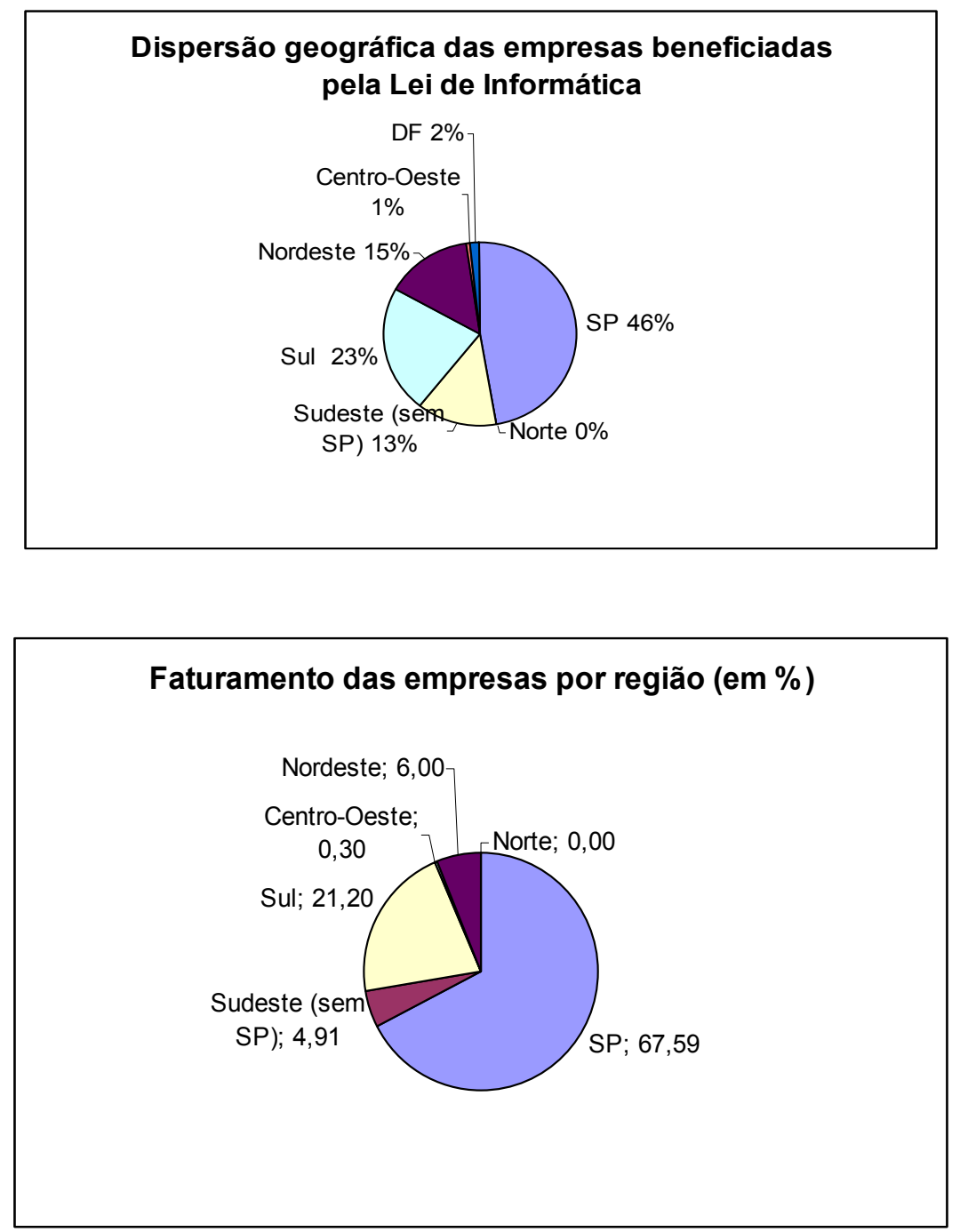

(Fonte: Ministério da Ciência e Tecnologia, dados colhidos em junho/20077).

Os limites da política para correção deste problema são, todavia, exíguos. Em 2004, a nova versão da Lei de Informática tentou fornecer um paliativo à questão, estabelecendo que as empresas estabelecidas nas regiões Norte, Nordeste e Centro-Oeste teriam o IPI mais reduzido, e um aumento da carga fiscal mais lenta. Os números de empresas cadastradas em 2007, no entanto, mostram que os efeitos desta tentativa são relativos.

Tentando sintetizar os principais pontos desta análise, pode-se afirmar que o PPB se mostrou um instrumento jurídico de política pública de grande valor. A estratégia de premiação - regulação por estímulos - empresarial foi amplamente acatada pelo setor privado, e a burocracia responsável se absteve de incluir exigências que, no cálculo

\footnotetext{
${ }^{7}$ É importante ponderar estes números com cautela, devido à existência de um programa do governo federal para a região de Manaus. A fraca presença da política de informática na região Norte pode muito bem ser afetada pela presença da política específica para aquela região. Assim, as empresas da região prefeririam optar pelos benefícios da ZFM, enfraquecendo a efetividade da política nacional naquela área.
} 
estratégico, pudessem representar um custo e desestímulo maior do que o benefício da isenção fiscal.

Assim, o direito, enquanto arcabouço normativo determinante de um mercado objeto de uma política pública, parece ter cumprido uma tarefa de indução da atividade econômica que transcende a pura definição de regras ou correção de falhas de mercado, conforme uma abordagem neoclássica ou neo-utilitarista. O PPB, na qualidade de uma ferramenta jurídica de política, foi capaz de cumprir ao menos em parte seus objetivos, limitando o movimento de interrupção da produção local pelo fornecimento externo.

Esta ferramenta obviamente encontrou limites à sua efetividade, levando-a a ser alvo de críticas, especialmente a ausência de internalização de etapas produtivas mais densas e a acumulação das empresas beneficiadas em pólos desenvolvidos, dificultando a regionalização. Parece-me claro, todavia, que tais problemas derivam mais da escolha política pela abertura de mercado do que do desenho institucional ou do arcabouço normativo deste instrumento.

\section{$\underline{4.2}$ Pesquisa e desenvolvimento (P\&D)}

Um segundo conjunto de contrapartidas exigidas pela Lei de Informática para fruição dos benefícios fiscais são os investimentos em P\&D. A análise desde um ponto de vista jurídico desses investimentos é de grande importância. Inicialmente porque estratégias de $\mathrm{P} \& \mathrm{D}$, e em última instância da inovação tecnológica decorrente, tornaram-se nas últimas décadas elementos essenciais de competitividade para as empresas e países no âmbito do comércio internacional contemporâneo. Pesquisa recente da OCDE afirma que os países no âmbito dessa organização vêm gastando cada vez mais com $\mathrm{P} \& \mathrm{D}$, havendo uma alta de cerca de 10\% no volume total de gastos entre 2000 e 2004. (OCDE, 2006, p. 9). No Brasil, segundo pesquisa do IPEA, as empresas que inovam em produtos ou processos têm maior faturamento e pagam melhores salários a seus empregados. (NEGRI, SALERNO E CASTRO, 2005, p.13). Desnecessário mencionar que todas essas vantagens são potencializadas no caso de um setor intensivo em tecnologia e com alta dinâmica tecnológica como a indústria de informática, em que, em muitos casos, a inovação perfazse não só como um componente de competitividade, mas como condição da própria sobrevivência da empresa no mercado. 
O assunto toma ainda uma outra dimensão no caso presente. Isto porque gerar recursos e fomentar as atividades de $\mathrm{P} \& \mathrm{D}$ na indústria podem ser entendidos como objetivos prioritários da política de informática brasileira. Assim, indagar se essa estratégia está funcionando e se as ferramentas jurídicas para tanto estão bem calibradas é questionar o próprio fundamento e sucesso da Lei de Informática enquanto política pública.

A importância da intervenção governamental na área de pesquisa tem forte fundamentação teórica e empírica, embora possivelmente seja um exagero dizer que se trata de uma unanimidade. Uma contribuição de especial relevância nesse sentido é o trabalho do prêmio Nobel Kenneth Arrow, segundo o qual as atividades de pesquisa e inovação apresentam três características que, para um modelo de concorrência perfeita, são consideradas falhas de mercado, impedindo assim o investimento e alocação ótima de recursos. São elas a presença de indivisibilidades, a não apropriabilidade completa dos resultados e a incerteza (risco). A presença dessas características, segundo Arrow, faz com que sejam destinados menos recursos para essas atividades do que o ideal, o que acarreta a necessidade de uma intervenção governamental realizando diretamente a pesquisa, financiando ou concedendo incentivos para sua realização. Em suas palavras:

\begin{abstract}
"esperamos que uma economia de livre empresa sub-invista em invenção e pesquisa (comparado com o ideal) porque é arriscado, porque o produto pode ser apropriado apenas limitadamente, e porque há retornos crescentes no uso. [...] a discussão prévia nos guia à conclusão de que para a alocação ótima para invenção seria necessário que o governo ou outra agência não gerida por critérios de lucro-e-perda financiasse a pesquisa e invenção." (ARROW, 1962, p. 152 e p. 156 , tradução nossa ${ }^{8}$ ).
\end{abstract}

Já foi também mencionado no primeiro capítulo a importância dada pelos autores da abordagem evolucionária às atividades de $\mathrm{P} \& \mathrm{D}$, e sua preocupação em estabelecer a forma adequada de seu financiamento em cada caso. Em especial, Nelson e Winter consideram que, devido às peculiaridades dos projetos de inovação tecnológica, é inapropriado deixá-los apenas sob o financiamento e controle do setor privado, sendo necessária a participação adicional do setor público, seja como financiador ou direcionador

\footnotetext{
8 "we expect a free enterprise economy to underinvest in invention and research (as compared with an ideal) because it is risky, because the product can be appropriated only to a limited extent, and because of increasing returns in use. [...] the previous discussion leads to the conclusion that for optimal allocation to invention it would be necessary for the government or some other agency not governed by profit-and-loss criteria to finance research and invention". (ARROW, 1962, p. 152 e p. 156).
} 
dos investimentos (embora os autores não deixem de retratar dos riscos e limites dessa intervenção). (NELSON E WINTER, pp. 546-560).

Uma vez mencionadas a importância econômica da P\&D e o reconhecimento, no plano teórico, do financiamento ou intervenção do setor público nessa atividade, cumpre indicar as razões de criação e adoção de um instrumento jurídico para promover a pesquisa no setor de informática após a abertura de mercado nos anos noventa. Na década de oitenta, as atividades de P\&D foram fortemente afetadas e estimuladas pela política pública vigente. Como uma estratégia de estufa, a reserva de mercado foi utilizada para geração de tecnologia e inovação na indústria de TI brasileira. Conforme Tigre, esta estratégia se mostrou frutífera em grande parte, permitindo o desenvolvimento de sistemas voltados às necessidades locais, como o caso da automação bancária. (TIGRE, 2000, p. 12).

Com a abertura de mercado dos anos noventa, uma parte considerável desses esforços foi abruptamente interrompida, especialmente em decorrência da mudança de estratégias das empresas locais, que abandonaram os próprios projetos (ou identificaram sua inviabilidade), e passaram a buscar acordos e parcerias para a venda de equipamentos importados. Neste novo cenário as atividades de P\&D perderam o caráter central do período anterior, motivo pelo qual se pode notar um decréscimo considerável com esses gastos, tanto em termos absolutos quanto relativos.

Gastos em P\&D das empresas de TI no Brasil (US\$ milhões)

\begin{tabular}{|l|c|c|}
\hline Ano & Gastos em P\&D & P\&D como \% de vendas \\
\hline 1987 & 207 & 5,4 \\
\hline 1988 & 259 & 5,1 \\
\hline 1989 & 394 & 5,7 \\
\hline 1990 & 302 & 5,0 \\
\hline 1991 & 275 & 3,6 \\
\hline 1992 & 312 & 3,6 \\
\hline 1993 & 299 & 3,1 \\
\hline 1994 & 377 & 4,3 \\
\hline 1995 & 443 & 4,5 \\
\hline 1996 & 536 & 4,4 \\
\hline $1997 *$ & 642 & 4,8 \\
\hline
\end{tabular}

Fonte: TIGRE, 2000

* Dados preliminares à época. 
A partir dos dados acima, pode-se verificar que, desde 1989, já se havia iniciado o processo de descontinuidade ou diminuição das atividades de $\mathrm{P} \& \mathrm{D}$, o que pode ser atribuído à expectativa do término da reserva de mercado, que, conforme a Lei 7.232/84, ocorreria em 1991. Isto constituía um severo problema que tinha que ser abordado na nova política, e, por esse motivo, a Lei 8.248/91 buscou conter a fuga de recursos e o encerramento dos projetos de pesquisa. Em sua versão original, a lei determinava que, para obterem os benefícios fiscais (principalmente isenção de IPI), as empresas de informática deveriam aplicar no mínimo $5 \%$ de seu faturamento bruto no mercado interno em atividades de P\&D no país, sendo 2\% destinados a convênios com centros ou institutos de pesquisa ou entidades brasileiras de ensino, oficiais ou reconhecidas.

O mecanismo instituído por esta ferramenta é algo muito próximo ao estabelecido pelo PPB, qual seja, a exigência de uma determinada obrigação ou atividade como contrapartida a um benefício fiscal. No entanto, a racionalidade aqui aplicada parece apresentar uma diferença substancial: a conjunção da redução fiscal com os gastos demandados aproxima este instrumento mais de um financiamento público dos projetos empresariais de P\&D do que de uma estratégia reguladora da atividade ou investimentos privados. Nessa lógica, tais projetos seriam financiados primordialmente pelo poder público, através das isenções físcais previstas na lei, não configurando assim custo efetivo para as empresas. Essa explicação faz sentido considerando que as firmas se encontram obrigatoriamente vinculadas a um projeto de $\mathrm{P} \& \mathrm{D}$, que deve constar de sua requisição ao MCT. Mais ainda, elas devem apresentar relatórios anuais para aprovação do ministério, reportando o andamento dos projetos e seus resultados.

Conforme Garcia e Roselino, a racionalidade desta política é de tipo bastante diferente da que caracterizava o período da reserva de mercado. Encontra-se calcada em uma economia aberta com intensas relações comerciais e concorrência internacional. Neste novo contexto foi abandonado o projeto de desenvolvimento tecnológico autóctone para o mercado interno (uma "substituição de importações", conforme os autores). Mas, ao mesmo tempo, isso não significou o abandono da inovação tecnológica, e sua virtude está em não deixar que os custos desse esforço recaiam sobre o consumo (afetando os preços). 
esforço tecnológico recairia integralmente, neste novo modelo, sobre a receita fiscal da União". (GARCIA E ROSELINO, 2004, p. 179).

A engenhosidade desta ferramenta está na superação do problema do custo de oportunidade existente no setor privado entre, de um lado, a redução de custos e a competitividade imediata dos produtos através da guerra de preços, e, de outro, o fomento às atividades de desenvolvimento, que deverão garantir a manutenção da competitividade no longo prazo via inovações. Nesta lógica, o papel do direito vem sendo o de viabilizar esse financiamento, "amarrando" institucionalmente a isenção fiscal e os projetos de P\&D nos termos expostos. Dito de outro modo, a partir do momento em que o setor público toma para si o custo da $\mathrm{P} \& \mathrm{D}$, reduz-se ou se anula o impacto dessas atividades no custo e preço final dos produtos.

Noto que não se trata de um arranjo institucional simples, sendo esta uma ferramenta jurídica com grande dificuldade de implementação. Principalmente, há aqui uma grande assimetria informacional em favor das empresas, que possuem todo o conhecimento específico acerca de seus próprios projetos de pesquisa, difícultando sobremaneira o trabalho dos técnicos do MCT para fiscalização. Este item será abordado na subseção (c) abaixo, mas refiro este problema aqui para ressaltar que, nos casos em que as empresas não possuem um compromisso efetivo com seus projetos de $\mathrm{P} \& \mathrm{D}$, elas tentarão se esquivar de suas obrigações ou reduzir esses gastos sem perder a isenção fisscal. Desta forma, este mecanismo jurídico deixa de cumprir sua função inicialmente prevista (financiamento dos projetos), sendo distorcido para apenas reduzir custos operacionais ou aumentar o excedente do produtor.

Apesar de algumas alterações pontuais, a mesma fórmula prevista na Lei 8.248/91 foi repetida nas legislações posteriores. Assim, a Lei 10.176/01 lançou mão da exigência dos mesmos 5\% para P\&D, inovando, no entanto, ao determinar que parte desses recursos fosse destinada a convênios com institutos de pesquisa da região da SUDAM, SUDENE e Centro-Oeste, o que sugere uma preocupação com a dispersão geográfica desses gastos, e ainda que parte fosse depositada no FNDCT. A última versão da lei, aprovada pela Lei 11.077/04, seguiu as mesmas linhas.

Outro dispositivo importante referente à P\&D estabelecido na Lei 8.248/91 é o seu artigo $6^{\circ}$, que concedia uma dedução do Imposto sobre a Renda e Proventos de qualquer 
natureza (IR) no valor das despesas com atividades de P\&D no país, até o limite de 50\%. Ao contrário dos demais incentivos citados, este benefício exauriu-se em 1997, conforme o artigo 10 da mesma lei.

Apesar de a lei (8.248/91 ou suas alterações posteriores) já determinar os principais marcos das contrapartidas em $\mathrm{P} \& \mathrm{D}$, pode-se afirmar que o detalhamento de suas regras, especialmente as definições e questões procedimentais, acabaram se concentrando nos Decretos de Regulamentação (792/93, 3.800/01 e 5.906/06), que, por esse motivo, podem ser considerados o núcleo normativo que descreve esta ferramenta. Assim, o Decreto 792/93 determinava que, para obter os benefícios fiscais, as empresas produtoras de bens de informática deveriam requerê-los ao MCT, conforme as portarias e instruções emitidas por este órgão. O CONIN era responsável por analisar as propostas submetidas, com base em uma série de fatores estabelecidos pelo decreto, dentre os quais estava a capacitação tecnológica da empresa, considerando o volume de recursos financeiros, materiais e humanos alocados às atividades de $\mathrm{P} \& \mathrm{D}$. Um detalhe importante é a definição de $\mathrm{P} \& \mathrm{D}$ feita no decreto. São consideradas incluídas nesse conceito as seguintes atividades de pesquisa $^{9}$, desenvolvimento ${ }^{10}$, treinamento em ciência e tecnologia ${ }^{11}$, serviço científíco e tecnológico ${ }^{12}$, e sistema da qualidade ${ }^{13}$.

Em sua evolução, essas normas regulamentares foram ampliadas e mais sistematizadas. O Decreto 3.800/01 estabeleceu mais claramente que, ao apresentar a solicitação de benefícios ao MCT, a empresa deve contemplar um Projeto de Pesquisa e Desenvolvimento, a ser iniciado no máximo em 180 dias da publicação da portaria que autoriza a fruição dos benefícios fiscais.

\footnotetext{
${ }^{9}$ Conforme o art. 14 do Decreto: trabalho teórico ou experimental realizado de forma sistemática para adquirir novos conhecimentos visando a atingir um objetivo específico, descobrir novas aplicações ou obter uma ampla e precisa compreensão dos fundamentos subjacentes aos fenômenos e fatos observados sem prévia definição para o aproveitamento prático dos resultados desse trabalho.

${ }^{10}$ Conforme o art. 14 do Decreto: trabalho sistemático utilizando o conhecimento adquirido na pesquisa ou experiência prática para desenvolver novos materiais, produtos ou dispositivos, implementar novos processos, sistemas ou serviços ou, então, para aperfeiçoar os já produzidos ou implantados, incorporando características inovadoras.

11 Conforme o art. 14 do Decreto: treinamento especializado de nível médio ou superior, bem como aperfeiçoamento e pós-graduação de nível superior.

${ }^{12}$ Conforme o art. 14 do Decreto: serviços de assessoria ou consultoria, de estudos prospectivos, de ensaios, normalização, metrologia ou qualidade, assim como os prestados por centros de informação e documentação.

${ }^{13}$ Conforme o art. 14 do Decreto: programas de capacitação e certificação que objetivem a implantação de programas de gestão e garantia de qualidade.
} 
Quanto aos resultados da política atual com relação à atividade de inovação, as análises pesquisadas dividem-se em elogios (especialmente as publicações e apresentações oficiais de órgãos e representantes do governo) pelo montante de recursos gerados, e críticas que ressaltam aspectos pontuais do arranjo institucional.

Conforme identificado na tabela extraída de Tigre (2000), sob a égide da política anterior os gastos absolutos e relativos (como porcentagem de vendas) de P\&D vinham crescendo, sendo este processo interrompido pela abertura de mercado na virada da década de noventa, quando esses valores começaram a declinar. Em 1993 inicia-se uma retomada das pesquisas no setor, sendo os valores absolutos de 1989 recuperados entre 1994 e 1995 , ou seja, após a nova política ter sido aprovada e regulamentada, e os primeiros PPBs e projetos de pesquisa aprovados. É, portanto, uma hipótese razoável argumentar que a política de informática, tal como juridicamente construída e implementada, foi de alguma forma relevante para a retomada do $\mathrm{P} \& \mathrm{D}$ e da inovação tecnológica durante esse período extremamente conturbado da indústria, o que é, em si, um grande mérito dessa intervenção governamental.

Esse resultado é condizente com o discurso oficial do governo quanto aos resultados da política. Conforme os dados publicados e apresentados, a Lei de Informática gerou nos oito anos de sua primeira fase (1994-2001) um volume de recursos que ultrapassou a casa dos 3,5 bilhões de reais, havendo ainda uma tendência de continuidade e aumento. Nos quatro últimos anos para os quais há dados publicados (2003-2006), o montante total estimado era de R 2 bilhões. (MCT, 2005).

Coerentemente com as destinações de recursos previstas na lei, no período 19932002 quase dois terços (61\%) do total de recursos foram empregados em pesquisas internas das próprias empresas. Embora se trate de uma fonte potencialmente enviesada, é importante mencionar que essas empresas alegam que os incentivos e contrapartidas da Lei de Informática foram de fundamental importância para o estabelecimento de robustos projetos e centros de pesquisa no país. Tomando dois exemplos que podem ser considerados casos de sucesso, cito o Centro de Pesquisa e Desenvolvimento da Ericsson e 
o Centro de Desenvolvimento de Software da Dell ${ }^{14}$, institutos de excelência mundial detidos por empresas com grande de grande porte no mercado internacional.

O número de instituições de ensino e centros de pesquisa cadastrados para receber os recursos ou convênios previstos na lei também é expressivo. Desde o início da política até o final de 2003, mais de 250 universidades e instituições de ensino e pesquisa acolheram investimentos a partir da Lei de Informática (SEPIN, 2003). Só em 2007 foram 74 instituições, sendo a maior parte desses recursos destinados ao Estado de São Paulo (SEPIN, 2008). O discurso dos representantes desses núcleos de pesquisas também tem sido favorável à política, e ressalta não apenas os recursos trazidos como a possibilidade de interação entre a pesquisa acadêmica e a dinâmica empresarial. Exemplos de centros de excelência que têm se especializado na indústria de informática e TI são a Universidade Federal do Rio Grande do Sul e a Universidade de Campinas ${ }^{15}$ (esta última pôde desenvolver uma parceria institucional de pesquisa de grande porte com a Ericsson e a IBM).

Ao lado do discurso oficial do governo e das instituições beneficiadas, no entanto, críticas e problemas foram e vêm sendo levantados contra a estratégia da política de informática de fomento às atividades de P\&D. Em geral, essas críticas se referem a questões pontuais, sem que configurem um desmerecimento ou proposta de desmonte completo da ação pública. Este dado reflete e pode ser compreendido como um sintoma do

14 Conforme artigo publicado por representante da Ericsson no seminário sobre resultados da lei de informática: "Em março de 2000, em função da importância do mercado brasileiro nos negócios globais da Ericsson e da importância da Lei de Informática, decidiu-se ampliar substancialmente as atividades de P\&D no Brasil, que até então eram realizadas na sede da empresa em São Paulo. Nesse contexto, no início de 2001, foi inaugurado o Centro de Pesquisa e Desenvolvimento em Indaiatuba, um dos maiores centros da Ericsson no mundo e o único da empresa na América Latina, além de representar uma das maiores e mais modernas estruturas para Pesquisa e Desenvolvimento de Software no País". (ERICSSON TELECOMUNICAÇÕES, 2003). No mesmo sentido quanto a Dell: "A partir de 2000, com a utilização dos recursos da contrapartida devida aos incentivos da Lei de Informática, foi criado no Brasil o Centro de Desenvolvimento de Software - GDC. [...] Neste cenário, a disponibilidade dos recursos da contrapartida aos incentivos da Lei de Informática foi o fator decisivo a favor de nosso país. Estes recursos viabilizaram o investimento em montagem, treinamento e certificação de equipes de desenvolvimento, e a sua manutenção durante a curva de aprendizado que levará a níveis internacionais de produtividade”. (DELL BRASIL, 2003). ${ }^{15}$ Conforme artigo do representante da Universidade Federal do Rio Grande do Sul - UFRGS "Pelos resultados e números apresentados anteriormente fica clara a importância que os projetos financiados através da Lei de Informática representam para o ensino, a pesquisa e o desenvolvimento nas universidades. Cabe destacar que o envolvimento de professores e estudantes em problemas do dia-a-dia das empresas traz uma importante visão e complementação aos conhecimentos tanto dos professores como dos estudantes". (UFRGS. 2003). E da Universidade de Campinas - UNICAMP “A Universidade captou aproximadamente R\$ 33 milhões nos últimos dez anos através de projetos beneficiados pela Lei de Informática. Nesta captação foram envolvidos sete Institutos e Unidades da UNICAMP através de mais de 270 convênios". (UNICAMP, 2003). 
quadro exposto no capítulo anterior de esvaziamento do debate em torno da política de informática e do grau relativo de consenso atingido a seu respeito. Não parece haver maiores dúvidas sobre o acerto da estratégia, mas apenas propostas de melhorias em um ou outro aspecto. Feita essa ressalva, passo abaixo a expor algumas das principais críticas levantadas contra a política, tal como implementada.

a) Diferença entre valores da renúncia fiscal e das despesas com $P \& D$

Conforme destacado, Garcia e Roselino argumentam que um dos principais méritos da política de informática atual é sua relativa "neutralidade" no conflito entre busca de eficiência dinâmica e alocativa. O sistema de benefícios fiscais e contrapartidas em P\&D teriam principalmente o fulcro de permitir às empresas desenvolver e maturar projetos para inovações, gerando ou sustentando sua competitividade no ambiente de economia aberta, em um típico esquema de concorrência schumpeteriana.

Partindo desse raciocínio, a política de informática não pode ser compreendida como uma mera renúncia fiscal para benefício da indústria local, uma vantagem inicial contra a concorrência internacional. Uma análise desse tipo, inclusive, rompe com a racionalidade exposta acima para esta ferramenta jurídica (financiamento público de P\&D), e representa uma desconsideração dos elementos de cunho neoclássico da PICE. Dessa forma, a confrontação da efetiva renúncia fiscal resultante da isenção de IPI e os gastos gerados em P\&D é de grande relevância para entender em que medida esta máxima está sendo seguida. 


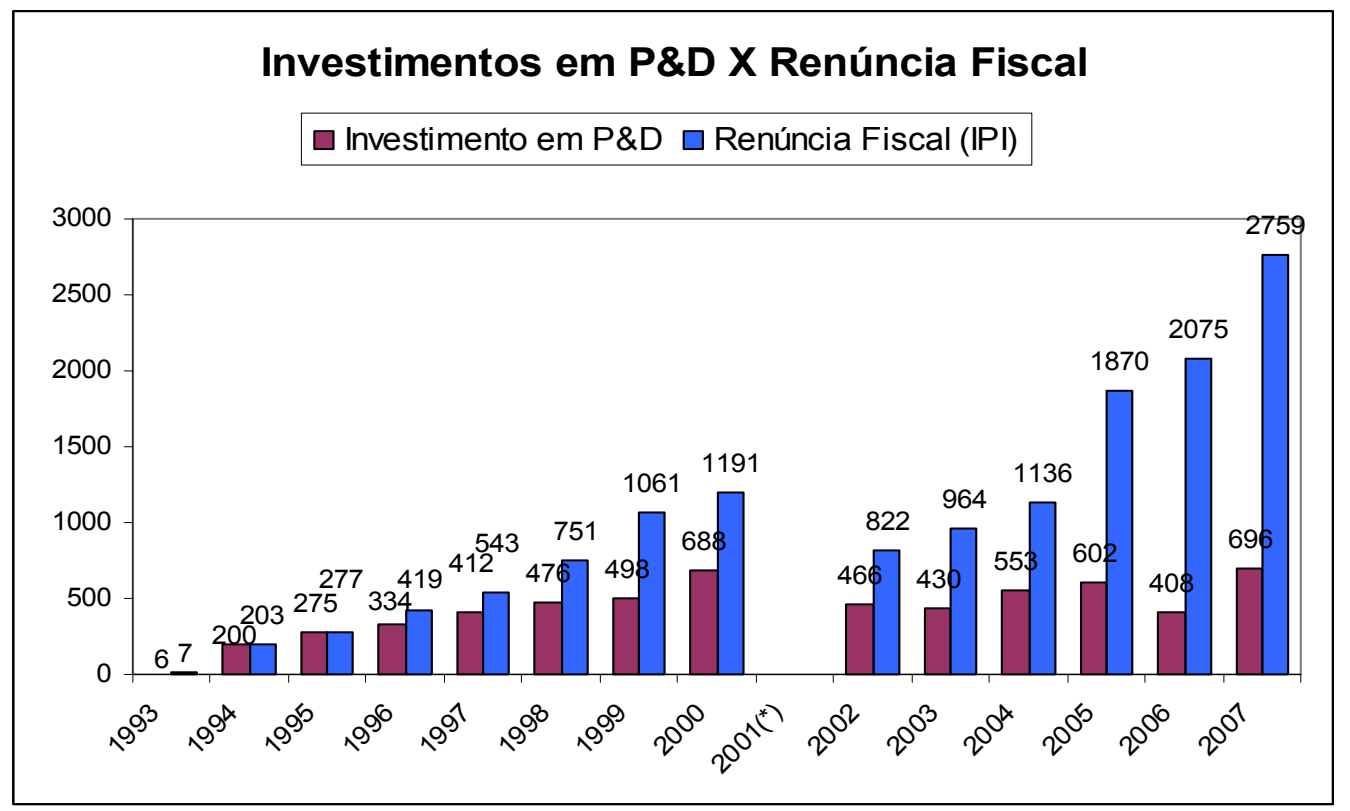

Em R \$ milhões.

(*) Ano da renovação (ver seção 3.6 do capítulo anterior)

(Fonte: até 2000 - MCT, 2004. Após - dados obtidos diretamente no MCT)

A partir dos dados dispostos no gráfico se nota que, gradativamente, tem se formado um crescente hiato entre o volume de recursos poupados pelas empresas com a isenção ou redução fiscal e o montante destinado à pesquisa e desenvolvimento. Esse ‘descolamento' entre o benefício fiscal e as despesas com P\&D certamente representa uma distorção da política.

Juridicamente, este fato pode ser explicado como uma má calibragem das regras e mecanismos que compõem este instrumento da política. Isto porque uma hipótese razoavelmente abrangente (embora simplificadora) pode apontar que este montante de renúncia fiscal não convertido em $\mathrm{P} \& \mathrm{D}$ tem sido apropriado como excedente pelos produtores, ou ainda utilizado como vantagem competitiva de preços contra bens e equipamentos eletrônicos importados. Qualquer dessas situações (em especial a primeira) afronta e não condiz com o interesse de uma política pública setorial em um ambiente de economia aberta.

Esse cenário não implica ou sugere uma automática redução dos benefícios fiscais (ou aumento da carga de gastos com P\&D). Abre-se aqui, entretanto, uma pergunta ou agenda de pesquisa que coloca em questão a racionalidade da política de informática. Não justificar o benefício fiscal da política de informática a partir de uma abordagem evolucionária de construção de capacitação tecnológica pode significar uma confirmação 
do argumento do Deputado Léo Alcântara, ex-relator da Comissão de Desenvolvimento Econômico, Indústria e Comércio da Câmara dos Deputados, de que a política de informática vem na verdade funcionando como um paliativo, um regime de exceção para livrar o setor da elevada carga tributária brasileira sobre o setor produtivo brasileiro ${ }^{16}$.

\section{b) Destinação dos recursos de $P \& D$}

Um outro indicador relevante refere-se ao caráter das atividades tecnológicas que empresas e centros de pesquisas de informática vêm desenvolvendo no país. O gráfíco e a tabela abaixo apresentam dados publicados pela SEPIN, e dá uma dimensão da direção que o esforço tecnológico gerado pela política tomou ao longo desses anos. O primeiro gráfico reflete os gastos em milhões de reais, no período de 1993 a 2002, enquanto a tabela apresenta dados mais atualizados, referindo-se apenas ao ano de 2007.

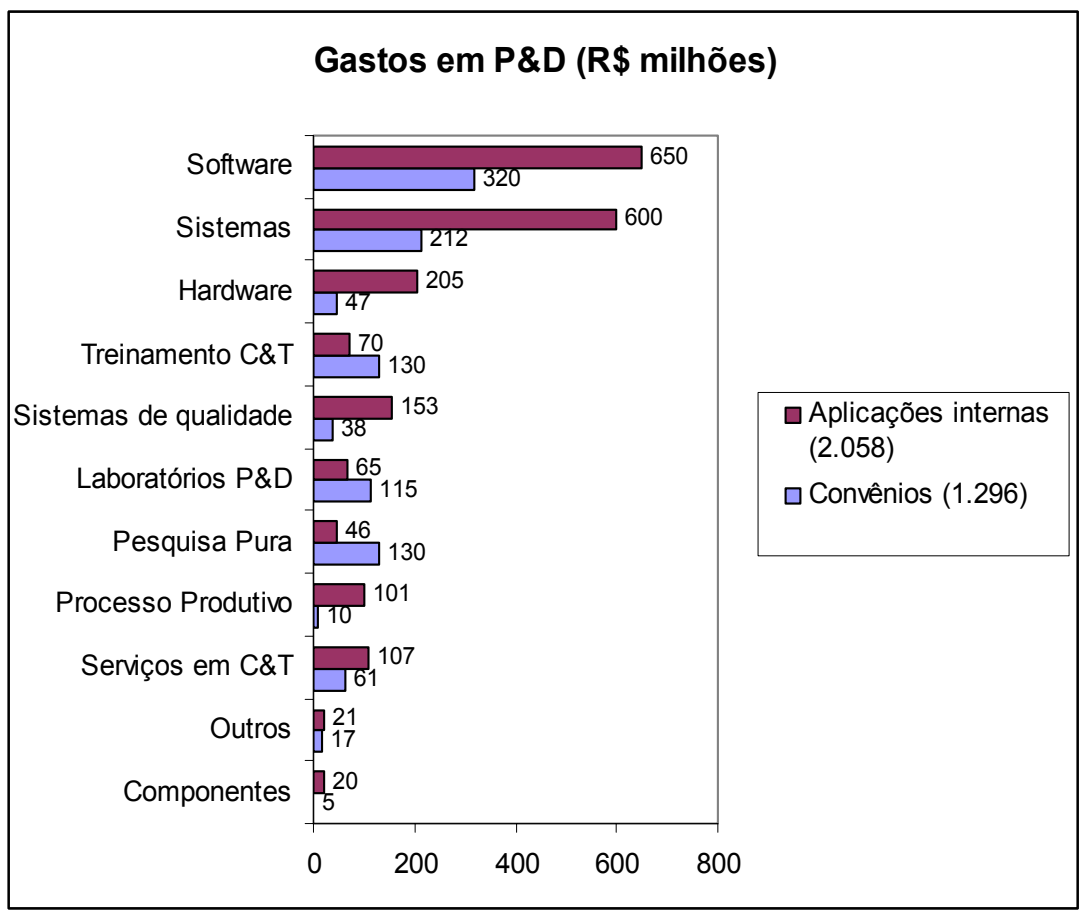

(Fonte: MCT, 2005 (apresentação))

\begin{tabular}{|l|c|c|}
\hline \multicolumn{3}{|c|}{ Investimentos em P\&D (2007) em RS milhões } \\
\hline Categoria & Nas instituições & Nas empresas \\
\hline Software, embarcado & 115,4 & 50,10 \\
\hline Software, aplicativo & 87,6 & 98,70 \\
\hline Capacitação e treinamento & 32,6 & 4,60 \\
\hline Software, outro & 27,4 & 21,70 \\
\hline Ensaios e testes & 20,2 & 1,60 \\
\hline
\end{tabular}

16 Parecer do relator, disponível em <http://www2.camara.gov.br/proposicoes/ loadFrame.html?link=http://www.camara.gov.br/internet/sileg/prop_lista.asp? fMode=1\&btnPesquisar=OK\& Ano $=2004 \&$ Numero $=3015 \&$ sigla $=P L>$. Acesso em 28.5.2008. 


\begin{tabular}{|l|c|c|}
\hline \multicolumn{3}{|c|}{ Investimentos em P\&D (2007) em R\$ milhões } \\
\hline Categoria & Nas instituições & Nas empresas \\
\hline Estudos e metodologias & 16,9 & 0,07 \\
\hline Equipamento (Hardware) & 16,8 & 97,00 \\
\hline Laboratório de P\&D & 12,9 & 1,10 \\
\hline Hardware com software embarcado & 12,8 & 40,20 \\
\hline Integração de sistemas & 4,8 & 3,40 \\
\hline Dispositivos & 3,3 & 12,20 \\
\hline Serviço tecnológico & 3,3 & 0,08 \\
\hline Processo produtivo & 2,7 & 5,40 \\
\hline Metodologia & 1,9 & 0,20 \\
\hline Software, componentes & 1,8 & 3,20 \\
\hline Componente microeletrônico & 0,9 & 1,40 \\
\hline Intercâmbio científico & 0,6 & 0,00 \\
\hline Também em outros & 0,2 & 8,80 \\
\hline Placa de circuito & 0,008 & 1,00 \\
\hline & & 350,75 \\
\hline TOTAL & 362,11 & \\
\hline
\end{tabular}

(Fonte: SEPIN, 2008)

Salta à vista o grande volume destinado às áreas de software e sistemas. Conforme Garcia e Roselino, isto representa basicamente investimentos em laboratórios voltados ao desenvolvimento e customização de programas. Esses centros apresentam custos de instalação muito menores, relativamente aos centros de desenvolvimento de hardware. Além disso, os autores alegam que as atividades desenvolvidas no Brasil são voltadas ao desenvolvimento de software de menor valor agregado, com pouca autonomia com relação às estratégias tecnológicas da corporação. As atividades são normalmente voltadas à codificação e programação, e raramente incluem a arquitetura de sistemas mais complexos. (GARCIA E ROSELINO, 2004, 183).

Este dado parece estar de acordo com a descrição que algumas das empresas realizaram de suas atividades de P\&D nos seminários de resultados da Lei de Informática. Em especial, grandes empresas multinacionais parecem focar os recursos de pesquisa advindos da política no setor de programas de computador. Exemplificativamente, nesse sentido foram as apresentações do representante da Dell Computadores ("No Brasil, por indução da Lei de Informática a Dell tem desenvolvido soluções de software para suporte a seus negócios em todo o mundo", cf. DELL BRASIL, $2003{ }^{17}$ ), da HP Computadores (cuja apresentação possui uma grande parte de descrição de projetos de desenvolvimento e pesquisa em software - HP BRASIL, 2003) e da IBM do Brasil ("Em contrapartida, as

\footnotetext{
${ }^{17}$ Faço entretanto a ressalva de que o GDC estabelecido pela Dell no Brasil possivelmente não permita que a crítica de Roselino e Garcia se aplique a esta empresa.
} 
aplicações internas subdividiram-se em: I. US\$ 139 milhões aplicados em Pesquisa e Desenvolvimento, majoritariamente em desenvolvimento de software[...]" - IBM DO BRASIL, 2003).

Uma ressalva relevante para este diagnóstico são as empresas de grande porte de capital nacional. A partir dos relatos feitos nos seminários da Lei de Informática pode-se perceber que algumas dessas empresas apresentam também um foco no segmento de hardware, e mesmo suas experiências com desenvolvimento de programas são relevantes para os produtos comercializados, amenizando assim, ao menos em parte, as críticas de Garcia e Roselino. A título de exemplo, cito os casos da Itautec (projeto "Microcomputador Linha Infoway" e "Infocluster - Processador de Alto Desempenho" ITAUTECH PHILCO, 2003), e Bematech (“A maioria dos desenvolvimentos internos da Bematech enquadram-se em desenvolvimento de hardware (eletrônico e mecânico) e desenvolvimento de firmware. O objetivo destes desenvolvimentos é a criação de equipamentos e soluções para os mercados alvo da Bematech: automação comercial e bancária” - BEMATECH, 2003) ${ }^{18}$.

Não tenciono com esse raciocínio defender uma abordagem nacionalista ou discriminatória das empresas de capital externo na política de informática, mas apenas suscitar a possibilidade de que, mais uma vez, parece haver uma falha no desenho institucional dos mecanismos jurídicos de incentivos a $P \& D$ da política de informática, na medida em que os esforços empreendidos pelas empresas podem não estar direcionados para os objetivos inicialmente pretendidos da política, ou para pesquisas com maior densidade tecnológica.

O problema desta crítica, a meu ver, é que, pelo menos no que tange às empresas multinacionais, ela acaba por revelar o paradoxo entre uma política que pretende estimular a P\&D empresarial em âmbito nacional, enquanto tais conglomerados do setor pensam esta atividade em escala global. A já mencionada modularização de tarefas permite a esses

\footnotetext{
${ }^{18}$ Esta é uma afirmação ou hipótese a respeito dos esforços inventivos dessas firmas que depende de uma pesquisa mais ampla. Sua verossimilhança, entretanto, pode ser atestada a partir de ampla pesquisa recente sobre inovação tecnológica em empresas brasileiras desenvolvida pelo IPEA. Neste estudo, os especialistas do instituto compararam diversas empresas a partir do viés da atividade inovativa, posteriormente cruzando e controlando dados e apresentando conclusões. No que tange à origem do capital, a pesquisa chegou à conclusão de que, controladas variáveis como local e porte, empresas de capital interno realizam substancialmente maiores gastos com P\&D do que suas similares estrangeiras. (NEGRI, SALERNO E CASTRO, 2005, p. 17).
} 
grupos dividir as diversas etapas das pesquisas em grupos com pouca autonomia ou espaço para desenvolvimento próprio. Assim, a pesquisa implementada no Brasil é apenas uma parte de um plano ou projeto global de pesquisa, no qual engenheiros e pesquisadores locais se encontram subordinados às diretivas e metas determinadas alhures. Neste cenário torna-se difícil compreender ou imaginar como uma política pública local poderia fazer mais para alterar ou influenciar essas estratégias de maneira significativa.

Com isso afirmo que talvez este problema transcenda a uma falha no desenho institucional da política, sendo propriamente uma característica do cenário contemporâneo da P\&D no setor de informática. Em todo caso, trata-se de um dado com que os policymakers têm que lidar, e que traz consigo a necessidade de uma reavaliação da política de incentivo à pesquisa no setor.

\section{c) Incerteza quanto aos gastos com P\&D e critérios de avaliação}

Os critérios e regras sobre as atividades e dispêndios a serem considerados como P\&D nos termos da lei, e a avaliação dos projetos e relatórios de gastos das empresas são duas questões especialmente problemáticas da Lei de Informática. A complexidade de se determinar o que se enquadra nessa categoria e o interesse (ou oportunismo) dos agentes em incluir o maior número de gastos para o cumprimento da determinação legal dificultam sobremaneira o trabalho do órgão do MCT responsável pela análise dos projetos.

Por esse motivo, esta foi uma das parcelas da regulamentação da Lei de Informática que mais se desenvolveu ao longo desta década e meia. A última versão apresentada pelo Decreto 5.906/06 define e descreve com alto grau de detalhamento as atividades de P\&D e o procedimento de fiscalização pelo MCT. Nesse marco regulatório, as empresas devem, anualmente (até o final de julho do ano subseqüente), apresentar um relatório descritivo, comprovando os dispêndios resultantes dessas atividades, seguindo um formato determinado pelo ministério. Pretendeu-se assim criar critérios objetivos que facilitem o trabalho das empresas na elaboração de seus relatórios, além de tentar viabilizar o enorme trabalho dos técnicos do MCT de analisar criticamente esses dados, em busca de fraudes e relatos falsos, além de fazer isso em um espaço de tempo minimamente razoável.

Embora a regulação mais estrita tenha remediado parcialmente o problema, a tensão existente não foi solucionada. De um lado se encontra o interesse empresarial de reduzir 
seus gastos efetivos com P\&D sem perder a isenção fiscal, e para chegar a esse objetivo muitas vezes são inflados os relatórios com diversas atividades e dispêndios que podem não ter relação alguma com a inovação tecnológica. E, do outro, o arcabouço jurídico da política, que, confome descrito, tem por objetivo não conceder um benefício unilateral à produção nacional, mas exigir contrapartidas que garantam a geração de conhecimento e tecnologia em território nacional.

O trabalho de conciliação desses dois pólos é realizado pelos técnicos do MCT, que analisam anualmente os relatórios de gastos das empresas. Em caso de reprovação,o MCT poderá concluir que a empresa não realizou os dispêndios exigidos em lei, determinando a suspensão dos benefícios legais. As informações oralmente obtidas sobre os trâmites da análise de relatórios no MCT e na SEPIN são de um órgão incapacitado de realizar esta tarefa. As empresas encaminham dezenas de documentos para um quadro técnico disponível relativamente pequeno e não especializado, e que por esse motivo não tem capacidade de analisar em pouco tempo e com o nível de detalhamento adequado todo o recebido.

Gerou-se assim ao longo dos anos uma situação de grande incerteza, em que as empresas demoravam em ter uma resposta de seus relatórios, e em caso de uma negativa, iniciava-se uma série de negociações e disputas com o MCT para a regularização, sem que isso resultasse na suspensão dos incentivos fiscais. Um caso expressivo que demonstra a complexidade e magnitude desse cenário ocorreu no início de 2005, quando o novo secretário da SEPIN, Marcelo Lopes, assumiu o posto e decidiu interromper as tratativas com empresas em débito com a política de informática. Nesta época, o MCT encaminhou à Receita Federal as informações de 52 empresas que, por não terem cumpridos os requisitos da legislação, deveriam ter seus tributos cobrados retroativamente, como se não tivessem sido beneficiadas. Nos cálculos do ministério, os valores de P\&D não utilizados superavam os 500 milhões de reais. Há casos em que elas gastaram menos do que a lei mandava e outros mais complicados, em que despesas apresentadas pelas empresas não foram reconhecidas como investimentos em $\mathrm{P} \& \mathrm{D}$ pelo governo ${ }^{19}$. A situação gerada foi singularmente caótica, porque nem a Receita Federal demonstrou saber exatamente como

\footnotetext{
${ }^{19}$ Conforme publicado em $<$ http://www.anpei.org.br/CLIPPING.aspx?id=711>. Acesso em 13.7.2006.
} 
cobrar os débitos fiscais que passaram a ser devidos, alguns dos quais já estariam prescritos conforme a legislação tributária.

Para superar esses problemas, a SEPIN vem utilizando, nos últimos anos, um software específico para que as empresas entreguem seus relatórios de gastos de P\&D. Esse novo procedimento daria maior agilidade ao processo, facilitando o trabalho dos técnicos do órgão e dando maior agilidade à análise. Até o presente não foram divulgadas estatísticas sobre os resultados dessa medida.

Uma outra proposta que vem sendo discutida para refinar os critérios de avaliação dos projetos das empresas é o estabelecimento de metas claras a serem atingidas. A idéia é adotar critérios mais rigorosos para examinar a qualidade dos investimentos realizados, simplificar alguns procedimentos burocráticos e acelerar a análise dos relatórios. Essas metas seriam objetivas e de fácil identificação pela SEPIN, como, por exemplo, número de patentes depositadas ou de publicações e artigos divulgados. Trata-se de uma alteração substantiva na forma de funcionamento das regras jurídicas de incentivos e contrapartidas em P\&D da política de informática. A lógica da política deixaria de ser a de um financiamento para qualquer projeto sem controle de resultados, mas dependeria de as empresas efetivamente demonstrarem que houve progressos científicos e tecnológicos e quais foram eles, conforme metas facilmente identificáveis e com maior dificuldade de serem burladas.

O setor privado em geral mostrou-se contrário à proposta do governo, alegando que estes são critérios acadêmicos muitas vezes não aplicáveis na rotina de pesquisa empresarial. De fato, estabelecer critérios objetivos para projetos de P\&D é um tema polêmico com várias divergências. Projetos de pesquisa em geral apresentam um forte grau de incerteza de seus resultados, sendo muito difícil entender e explicitar, a priori, quais serão os produtos finais a serem obtidos, se existirem. Conforme Arrow, "pela própria definição de informação, invenção deve ser um processo arriscado, em que o resultado (informação obtida) não pode ser perfeitamente prevista a partir dos insumos (inputs). (ARROW, 1962, p. 149, tradução nossa ${ }^{20}$ ).

\footnotetext{
20 "by the very definition of information, invention must be a risky process, in that the output (information obtained) can never be predicted perfectly from the inputs". (ARROW, 1962, p. 149).
} 
A proposta do governo, no entanto, não é descabida e encontra respaldo na literatura. O principal ponto é que, ainda que se trate de uma atividade dotada de risco e incerteza, mitigar esse risco ao não exigir qualquer contrapartida concreta em resultados gera um novo problema, representado pelo risco moral (moral hazard) dos agentes. Arrow aborda esta questão ao estudar a utilização do contrato de seguro para evitar o esvaziamento ou sub-investimento na atividade de pesquisa. Segundo o autor, o fator moral limita essa proposta, na medida em que o seguro altera os incentivos econômicos dos agentes, proporcionando o descuido e falta de compromisso para com os resultados, já que os riscos foram transferidos a terceiros. Conclui afirmando que "medidas que aumentam a eficiência da economia com relação à tomada de risco podem diminuir sua eficiência técnica". (ARROW, 1962, p. 145, tradução nossa ${ }^{21}$ ).

No caso da política de informática, poderia se afirmar que há uma origem dupla para o risco moral das empresas. Em primeiro lugar, porque os custos do processo são financiados pelo poder público, através dos incentivos fiscais, o que pode diminuir o comprometimento das firmas com resultados que efetivamente impactem seus resultados e competitividade. Além disso, considerando que o grande mote atrativo da política para o setor privado são esses incentivos, não é inadequado argumentar que a contrapartida em P\&D é vista por diversas empresas como apenas um custo a ser reduzido, o que certamente tem sérios impactos no resultado final da atividade inovativa do setor.

Dessa forma, parece positiva a proposta e debate sobre critérios mais rígidos para a análise dos projetos privados, contando com indicadores de resultados. Não se trata de um debate simples, e possivelmente seja muito difícil estabelecer uma regra geral que se aplique a todos os casos. Entretanto, a situação atual tem demonstrado o acerto das formulações de Arrow sobre risco moral, e uma modificação no arcabouço regulatório que aumente o compromisso empresarial com a pesquisa parece necessária e premente.

Por fim, um último ponto que vem sendo muito debatido e criticado são os centros de pesquisa privados que recebem continuamente volumes crescentes de recursos advindos da Lei de Informática. Conforme a legislação, dos 5\% exigidos para P\&D, 2,3\% devem ser aplicados mediante convênio com centros ou institutos de pesquisa ou entidades brasileiras

21 "steps which improve the efficiency of the economy with respect to risk bearing may decrease its technical efficiency”. (ARROW, 1962, p. 145). 
de ensino, parte localizada no norte, nordeste ou centro-oeste do país. O aprofundamento das relações de pesquisa entre setor empresarial e academia, e a injeção de recursos em instituições dedicadas ao desenvolvimento tecnológico eram alguns dos objetivos pretendidos com essa medida.

Entretanto, tem-se noticiado que algumas empresas menos conectadas com os objetivos da política vêm buscando alternativas para internalizar esses recursos. Nesse sentido, essas firmas constituíram ou firmaram acordos com centros e institutos de pesquisa que, na verdade, são apenas extensões externas dos laboratórios ou departamentos de P\&D internos, ou recebem a porcentagem devida dos investimentos mas, em troca disponibilizam material humano ou capital fixo para ser utilizado internamente pela empresa investidora. (NASSIF, 2003). Esses artifícios representam distorções da política, na medida em que minam os esforços para inovação tecnológica pretendida. Ademais, sendo centros voltados unicamente ao interesse empresarial, não têm a possibilidade de efetiva geração de spillovers tecnológicos, como institutos ou centros conceituados dedicados à pesquisa.

Para tentar evitar essa prática, já a Lei 10.176/01 passou a exigir que os centros ou institutos de pesquisa fossem cadastrados no CATI, para que assim se pudesse ter algum controle sobre os projetos e convênios formulados com essas instituições. Não há dados ou informações mais precisas acerca do montante de recursos que teriam sido desviados por meio desta tática, nem da eficácia que a exigência do cadastro teve em evitá-la.

Tentando extrair alguma lição ou idéia dos problemas levantados, nota-se que em regra eles advêm de uma incompatibilidade entre os objetivos da política e a racionalidade do empresariado. Isto significa que, para parcela das empresas beneficiadas, a atividade de inovação não representa maior importância. Ainda que isto possa parecer um contra-senso em um setor econômico cuja lucratividade e sobrevivência dependem da constante inovação, tais empresas podem, na prática, apenas figurar como revendedoras ou prestadoras de serviços. Para esse grupo de agentes, a política de informática é apenas um meio de ver sua carga tributária e preços reduzidos.

Identificou-se, portanto, um obstáculo central que vem dificultando ao arcabouço jurídico cumprir com seu papel instrumental de financiamento público à pesquisa. Há um 
impasse ou divergência entre os objetivos estabelecidos de uma política pública e os do setor econômico beneficiado por ela. Este impasse levou a uma redução dos resultados esperados desta ferramenta e a um aumento dos custos de focalização, na medida em que o MCT tem que mobilizar técnicos para analisar cada vez mais criteriosamente os gastos com P\&D das empresas.

\subsection{O Fundo Setorial CT-INFO}

$\mathrm{Na}$ qualidade de uma política pública juridificada, a Lei de Informática tem necessariamente objetivos e metas que transcendem o interesse individual das firmas que compõem os setores atingidos, ainda que deva haver (e de fato haja) alguma convergência entre essas duas esferas ou, mais ainda, que a forma de atingir os objetivos de âmbito público passe pelo favorecimento ou benefício de um segmento do setor privado. Até aqui me preocupei exclusivamente com medidas que afetam diretamente a estrutura, produção, comercialização ou atividades inovativas das empresas.

Mas a política de informática contempla também ações que não visam à geração imediata de capacitação tecnológica das empresas. São programas e medidas que buscam, em um âmbito geral e não individual, aumentar o conhecimento e capacidade de concorrência do setor de informática nacional. Aqui, conquanto haja financiamento com recursos advindos da Lei de Informática e pressuponha a participação de empresas e centros de pesquisa, os esforços são em geral geridos pelo poder governamental, que os direciona consoante uma racionalidade não privada para suprir deficiências ou remover gargalos que, em sua análise, não estejam sendo solucionados a contento pelo setor privado. São essas medidas principalmente os chamados 'Programas Prioritários em Informática' e o aporte de recursos no Fundo Nacional de Desenvolvimento Científico e Tecnológico - FNDCT.

Os programas prioritários precederam esta iniciativa, e, embora não estivessem presentes no corpo da lei, foram previstos em sua regulamentação. O Decreto 792/93 aceitou como dispêndio em P\&D para fins da lei a participação ou aporte de recursos financeiros em programas e projetos de interesse nacional considerados prioritários pelo MCT. O primeiro núcleo de programas prioritários, no entanto, só foi aprovado no final de 1994, através da Portaria MCT 200, e era composto do que até hoje são os principais programas financiados pela lei: a Rede Nacional de Pesquisa - RNP, o Programa Nacional 
de Software para Exportação - SOFTEX 2000 e o Programa Temático Multiinstitucional em Ciência da Computação - ProTeM-CC. Em 2002, já na vigência da nova Lei 10.176/01, o CATI confirmou esses três programas como prioritários, aprovando ainda mais dois, o Programa Rede de Desenvolvimento de Competências em Tecnologias da Informação e Comunicação - RDC-TIC e o Programa Nacional de Microeletrônica - PNM Design, além do mais recente deles, o Projeto Manufatura e Qualificação da Eletrônica de Produtos com Tecnologia da Informação e Comunicação - Hardware BR, aprovado em 2006.

Um detalhe acerca desses programas prioritários é que não há qualquer obrigatoriedade de participação privada em seus projetos. Ou seja, trata-se de uma prerrogativa da empresa investir ou não neles, uma alternativa oferecida pelo setor público a uma parcela do investimento interno exigida pela lei. $\mathrm{O}$ aporte de recursos nesses programas, portanto, dependia (e ainda depende) do convencimento das empresas beneficiadas, ou ainda, como ocorre em alguns casos, de seu interesse em investir devido à fácil comprovação desses gastos, evitando problemas posteriores com a sua aprovação pelo MCT.

Este cenário é alterado a partir de 2001, quando a Lei 10.176/01 passa a exigir que ao menos $10 \%$ dos investimentos necessários com P\&D sejam depositados em recursos financeiros no FNDCT, o que convencionalmente ficou conhecido como o fundo setorial CT-Info. A mudança de estratégia não é ocasional, e decorre de uma evolução e dinâmica própria do FNDCT, cujos objetivos transcendem à política de informática.

Em termos teóricos, os fundos de incentivo à ciência e tecnologia possuem forte embasamento. Descrevi anteriormente o debate sobre a importância da política industrial e inovação tecnológica. É reconhecido que apenas os recursos privados são insuficientes para atingir o nível ideal ou adequado de $\mathrm{P} \& \mathrm{D}$, devido às peculiaridades intrínsecas desta atividade, especialmente seu alto grau de incerteza e não apropriabilidade do total de seus resultados (ou suas externalidades positivas), que acabam por inibir o investimento e afastar o agente privado.

Parte desses problemas é solucionada através da disseminação do risco e incerteza dos resultados de projetos em mercados de valores mobiliários e outros. Isto ocorre especialmente em países com mercados maduros e com um grande volume de recursos 
movimentados. Mesmo assim, mantiveram-se abertos o espaço e necessidade para a atuação e investimento estatal. Independente de seus discursos quanto à política econômica adotada, os governos parecem compreender a relevância da complementação dos investimentos privados através de fundos e recursos públicos. No último estudo publicado pela OCDE sobre ciência e tecnologia, identificou-se um aumento nos gastos proporcionais de P\&D sobre o PIB, sendo esse aumento em boa parte devido a uma maior participação do setor público. Em 2004, o investimento do governo dos Estados Unidos com P\&D alcançava $1,1 \%$ do PIB (o total era de $2,68 \%$ ), o governo japonês investia $0,72 \%$ e a França 1,0\%. (OCDE, 2006, p. 23).

Este diagnóstico é agravado, entretanto, em países com mercado pouco consolidado. Conforme Bastos, nessas nações foi necessário estruturar arranjos institucionais distintos para o financiamento da pesquisa e inovação, seja através de uma aproximação entre bancos privados e empresas inovadoras, ou de uma maior intervenção governamental, com a criação de bancos de desenvolvimento ou de políticas de crédito seletivo. (BASTOS, 2003, p. 235). Este é nitidamente o caso brasileiro, no qual, devido ao pouco número de empresas que se dedicam à inovação, o Estado termina por arcar com cerca de $60 \%$ dos gastos com P\&D na atualidade, conforme dados do IPEA (SALERNO E KUBOTA, 2008, p. 24).

Foi dentro desse marco teórico e problema prático de financiamento da inovação que, no final da década de sessenta, foi criado o FNDCT (Decreto-Lei 719/69), sob administração da FINEP, com o objetivo de "dar apoio financeiro aos programas e projetos prioritários de desenvolvimento científico e tecnológico, notadamente para implantação do Plano Básico de Desenvolvimento Científico e Tecnológico” (art. $1^{\circ}$ ). O surgimento do FNDCT é considerado um momento relevante e um salto qualitativo para o sistema nacional de ciência e tecnologia. Segundo Pereira, a grande novidade e promessa do fundo era a autonomia orçamentário-financeira desse sistema de inovação, que passaria a contar com recursos assegurados. (PEREIRA, 2005, p. 7).

A promessa e expectativa geradas com o FNDCT foram, no entanto, em grande parte frustradas pela inconstância e instabilidade do recebimento de recursos nas décadas seguintes, o que acabou por prejudicar o planejamento de longo prazo e o financiamento sustentável de projetos. Outras críticas levantadas eram o alijamento de atores relevantes e 
a falta de eficiência da gestão. (PEREIRA, 2005, p. 7). Paradoxalmente, o momento de auge da antiga política de informática, a década de oitenta, representou também o momento de declínio e agravamento do modelo do FNDCT como instrumento financiador do P\&D nacional. Conforme Bastos:

\footnotetext{
“[...] tal situação agravou-se a partir da década de 1980, prejudicando a execução de pesquisas fundamentais e comprometendo a capacidade de inovação da economia brasileira. A restrição fiscal afetava não apenas as dotações de recursos do Tesouro, mas também os empréstimos externos, pela exigência de contrapartida local" (BASTOS, 2003, P. 237).
}

Este problema se acentuaria ainda mais na década de noventa. O fundo é restabelecido em 1991 pela Lei 8.172, devido a uma exigência da Constituição Federal22. Na Câmara dos Deputados sua aprovação é feita de forma razoavelmente consensual, não havendo registro de um debate mais crítico e aprofundado sobre a utilidade e problemas enfrentados $^{23}$. Ao longo da década, as restrições orçamentárias decorrentes dos planos de estabilização e dos juros da dívida pública comprometeram ainda mais os recursos do FNDCT. Conforme dados do MCT, durante esses anos o volume da execução financeira anual do fundo sequer conseguiu retornar àquele obtido em 1989 (algo equivalente a 200 milhões de reais) $)^{24}$.

Este era o cenário do FNDCT e, de maneira geral, dos recursos destinados à Ciência e Tecnologia - C\&T ao final da década de noventa, com pouco fôlego de ação e instabilidade de fontes. Este pode ser considerado o problema ou razão que levou à inovação do ordenamento jurídico através da formulação de um novo instrumento ou forma de financiamento de P\&D no país, que viria a afetar a política de informática. A solução proposta foi a instituição de uma tributação ou outra espécie de receita que pudesse de alguma forma estar vinculada a projetos de pesquisa e inovação, não estando sujeita a outras necessidades e questões de orçamento, em especial a constituição de superávit primário para pagamento de encargos da dívida pública.

\footnotetext{
${ }^{22} \mathrm{O}$ artigo 36 do Ato das Disposições Constitucionais Transitórias declarou extintos todos os fundos que não fossem ratificados pelo Congresso no prazo de 2 anos. Noto que este prazo não foi obedecido, razão pela qual a Lei 8.172/91 teve que ser aprovada com efeito retroativo.

${ }^{23}$ Conforme registro publicado no Diário do Congresso Nacional sobre o PL 5.994/90, em 13.12.1990. Disponível em <http://www2.camara.gov.br/proposicoes/loadFrame.html?link=http://www.camara.gov.br/ internet/sileg/prop_lista.asp? fMode $=1 \&$ btnPesquisar $=\mathrm{OK} \& A n o=1990 \&$ Numero $=5994 \&$ sigla $=\mathrm{PL}>$. Acesso em 8 jan. 2009.

${ }^{24}$ Valor atualizado para dezembro de 2005, conforme MCT, 2006.
} 
A partir deste objetivo foram criados os chamados fundos setoriais, sendo a primeira experiência iniciada já em 1997, com recursos advindos de royalties derivados da produção de petróleo e gás natural (o CT-petro) ${ }^{25}$. Posteriormente (a partir de 2001), outros 15 fundos foram criados. São eles, no total, 14 fundos efetivamente setoriais, ou seja, obtêm recursos de um determinado setor da economia e têm destinação vinculada ao mesmo (CT-Aeronáutico, CT-Agronegócio, CT-Amazônia, CT-Aquaviário, CT-Biotec, CT-Energ, CT-Espacial, CT-Hidro, CT-Info, CT-Mineral, CT-Petro, CT-Saúde, CTTransportes e o FUNTTEL); além de 2 fundos chamados transversais, por comportarem ações horizontais e não específicas (Fundo Verde-Amarelo - FVA, destinado à interação universidade empresa, e o CT-Infra).

As receitas dos fundos advêm principalmente das seguintes fontes: (i) contribuição das empresas do setor (CT-Info), (ii) contribuições incidentes sobre o resultado da exploração de recursos naturais pertencentes à União (caso do CT-Petro, CT-Espacial), (iii) parcelas do IPI de certos setores (FVA), e (iv) parcela da CIDE de certos setores (CTSaúde e CT-Biotec).

Uma ressalva importante a ser feita é que não foram constituídos diferentes fundos financeiros apartados entre si. Na realidade, com a exceção do Funttel, todos os demais são apenas fontes de receitas de um único fundo, o FNDCT, embora tais recursos tenham sua utilização vinculada para projetos específicos do setor que os financiou (ou para o propósito especificado, no caso dos fundos transversais). Nesse sentido, a terminologia "fundos setoriais" é imprecisa, embora o seu uso generalizado facilite a identificação, razão pela qual prossigo adotando-a.

Como mencionado, a partir da Lei 10.176/01 as empresas beneficiadas passaram a ter que depositar $10 \%$ dos recursos exigidos em P\&D no CT-Info. Além disso, a lei estabelece outras fontes de recursos ao fundo: caso as empresas não cumpram com o volume de P\&D exigido, sua regularização dependerá de depósito do valor devido, atualizado e acrescido de $12 \%$, no fundo; e até $2 / 3$ dos 2,7\% de investimentos residuais (ou seja, sem destinação obrigatória) exigidos podem ser aplicados no CT-Info, para atender ao

\footnotetext{
${ }^{25}$ Instituído pela Lei 9.478/97, regulamentado pelo Decreto 2.851/98.
} 
Programa de Apoio ao Desenvolvimento do Setor de Tecnologias da Informação, gerido pela Comitê da Área de Tecnologia da Informação - CATI.

A importância do CT-Info, sob a perspectiva da racionalidade jurídica, está em que os recursos originados pela Lei de Informática deixam de financiar exclusivamente o P\&D privado, como visto na seção 4.2 acima. A partir da instauração deste fundo, foi juridificada uma fonte de financiamento de projetos no setor de tecnologia da informação que, por seu alto risco ou valor do investimento, poderia não ser levado a cabo pelo setor privado, por ausência de interesse das firmas de capital externo, ou ainda de escala ou tecnologia pelas empresas nacionais. O Estado cumpre aqui um papel relevante, complementando o mercado em uma atividade que, conforme a literatura consultada, possui falhas de mercado que podem levar a um investimento insuficiente. Ao contrário dos agentes econômicos, o setor público pode realizar pesquisas com uma menor preocupação com problemas como a apropriabilidade e as externalidades dessas inovações, já que não há um propósito exclusivo de lucratividade nessas atividades, sendo relevantes também seus benefícios sociais e o conhecimento gerado para a comunidade científica.

Dentro dessa racionalidade, o direito possui um importante papel a ser exercido. $\mathrm{O}$ arcabouço jurídico (em especial a própria Lei de Informática) é utilizado em uma tentativa de garantir o fluxo constante de recursos para o CT-Info e os projetos por ele financiados já que a própria Lei 10.176/01 determina que tais valores destinem-se, exclusivamente, à promoção de projetos estratégicos de pesquisa e desenvolvimento em TI. Desta forma, seria possível superar o problema da instabilidade de recursos que caracterizou o FNDCT em praticamente toda sua história (idéia que se mostrou frustrada pelo problema do contingenciamento dessas verbas, conforme será visto abaixo).

No complexo normativo relacionado à Lei de informática há pouco mais sobre o CT-Info além das regras e fontes de seu financiamento. Como mencionei, a administração do fundo e dos projetos selecionados para receber recursos é realizada pela FINEP (com assessoria do CATI, conforme o art. 22 do Decreto 3.800/01). As normas de funcionamento são em geral aplicáveis a todos os fundos setoriais, havendo pouco a ser determinado normativamente sobre este fundo em específico no arcabouço da política de informática. Neste sentido, parece adequado afirmar que a concretização deste instrumento 
já se encontrava em grande parte estabelecida na própria lei (10.176/01), e que, neste sentido, ela pode ser considerada o núcleo normativo de descrição desta ferramenta.

Neste caso, todavia, a concretização da ferramenta pela própria lei não causa um entrave ou engessamento. Ao contrário, considerando que o problema a ser resolvido pela criação do CT-INFO era exatamente a instabilidade dos recursos para projetos de inovação, faz sentido que a solução encontrada, ou que a fonte estabelecida para tais aportes, encontre-se explicitada em lei e que seja de difícil alteração (demandando nova lei aprovada pelo Congresso Nacional). Isto, em teoria, permitiria que o arcabouço jurídico exercesse seu papel de garantidor de recursos financeiros.

Quanto aos resultados e sucessos obtidos, de 2001, quando foi implementado, a 2007, o CT-INFO aplicou em programas de fomento e capacitação de recursos humanos no setor de tecnologia da informação um volume anual médio de mais de 18 milhões de reais, e até agosto de 2008 o valor total de todos os anos ultrapassava os 135 milhões ${ }^{26}$.

Outros resultados positivos do CT-Info podem ser extraídos a partir dos programas financiados. Inicialmente, a questão da regionalização dos recursos, um dos pontos sempre debatidos e reivindicados nos debates sobre a Lei de Informática e os fundos setoriais, parece ter encontrado uma solução, ainda que parcial. Nos anos de 2002 e 2003, cerca de 7,5 milhões de reais, ou $20 \%$ do total, apoiaram projetos nas regiões Norte, Nordeste e Centro-Oeste. Dentre os programas apoiados encontram-se incubadoras de empresas, capacitação de recursos humanos, fomento e financiamento de grupos acadêmicos e um programa de apoio e desenvolvimento tecnológico em software livre. (SEPIN, 2003).

Cabe, no entanto, ressalvar que, embora apresente relevância no âmbito da política setorial de informática, o CT-Info possui importância bem reduzida no conjunto total de recursos do FNDCT. Especialmente a partir de 2003, quando os demais fundos já haviam sido instituídos e estavam gerando receitas, a participação do CT-Info foi declinante, usualmente ficando entre $1,5 \%$ e $2,5 \%$ do total.

\footnotetext{
26 Valores empenhados, liquidados e efetivamente pagos, não atualizados ou corrigidos. Ressalvo que encontrei uma grande disparidade nas publicações analisadas sobre os números de arrecadação, gasto e reserva de contingência do FNDCT. Optei por utilizar os dados atualmente publicados e disponíveis no website do MCT, que fornece os orçamentos dos fundos - <http://www.mct.gov.br>. Acesso em 1 nov. 2008.
} 
Ainda assim, em vista do exposto anteriormente, é razoável afirmar que a instituição do CT-Info atingiu alguns de seus objetivos propostos. Em especial, ainda que as cifras possam ser consideradas insuficientes, há uma estabilidade e expectativa de constância dos recursos do fundo, o que permite o planejamento e execução de projetos de período de maturação mais longo, e que por esse motivo possam servir a propósitos distintos da maximização imediata de lucros, como a construção de novos pólos de tecnologia e geração de capital-semente de novas empresas.

A esse respeito, um estudo especialmente relevante e otimista sobre o FNDCT que pode ser transposto para a realidade do CT-Info foi realizado por Negri, Negri e Lemos, para publicação do IPEA sobre inovação tecnológica no Brasil. Os autores estudaram os desembolsos e projetos do fundo em seus primeiros anos, em especial aqueles nos quais havia associação entre empresas (privadas ou públicas) e universidades ou institutos de pesquisa (chamado de "FNDCT Cooperativo"). Para tanto, foi elaborado um modelo que pretendia explicar, dentre outras coisas, quais as empresas com mais chances de serem beneficiadas pelo fundo, como os projetos afetavam sua produtividade e esforços em P\&D e, principalmente, se o FNDCT efetivamente incentivava e gerava novos recursos para inovação, ou se, ao contrário, perfazia apenas um deslocamento de investimentos (efeito crowding out). (NEGRI, NEGRI E LEMOS, 2008).

Os resultados apresentados são favoráveis e concedem crédito, ainda que limitado por alguns problemas, aos fundos e à estratégia do FNDCT Cooperativo. O modelo leva ao argumento de que as firmas beneficiárias possuem gastos em $\mathrm{P} \& \mathrm{D}$ superiores aos de suas similares que não participaram desses projetos, o que é um indicativo do potencial fomentador do fundo. Conforme a publicação, “(...) além de não serem observados efeitos de crowding out decorrentes do FNDCT nos gastos privados em P\&D, pode-se verificar também efeitos positivos e significativos do programa nesses gastos" (NEGRI, NEGRI E LEMOS, 2008, P. 312). O impacto final é, nessa esteira, positivo e condizente com os propósitos pelos quais os fundos foram constituídos.

Os efeitos são, contudo, limitados por alguns problemas que afetam em especial os recursos e capacidade de financiamento do CT-Info e do FNDCT como um todo. Conforme os estudos consultados, tais problemas são principalmente a diminuição de outros recursos destinados à ciência e tecnologia, o contingenciamento de verbas e falhas 
na gestão. Devido a sua relevância em termos de valores e pertinência com o tema da regulamentação jurídica, vou me ater aos dois primeiros mencionados.

Tais problemas têm uma origem comum, que é a restrição dos gastos governamentais, especialmente a partir da promulgação da Lei de Responsabilidade Fiscal (Lei Complementar 101) em 2000. Analisando a série histórica de gastos com C\&T do MCT, Pereira percebeu um acentuado viés de queda a partir da segunda metade da década de noventa. Este impacto não foi sentido, entretanto, justamente porque os recursos dos fundos setoriais passaram a cobrir essa redução. Assim, os altos valores dos fundos que foram se criando a partir de 1998 serviram como um mecanismo de compensação, permitindo ao ministério reduzir seus gastos com atividades de fomento, cumprindo com as determinações orçamentárias do governo. A maior evidência disso seria o fato de que apenas em 2003, contando portanto com os recursos do FNDCT, os investimentos totais do MCT conseguiram retornar ao nível de 1996 (1,92 bilhão de reais) (PEREIRA, 2005, p. 12)

O autor nota que, já em 2003, o FNDCT era responsável por cerca de 30\% dos investimentos totais do MCT com ciência e tecnologia. Esta é uma considerável distorção de seus objetivos iniciais, que era constituir um acréscimo de recursos estáveis ao sistema nacional de inovação. Ao contrário, a análise de Pereira revela que parcela dos fundos setoriais vêm na verdade servindo de fato para camuflar ou preencher o vazio deixado pelo esvaziamento de recursos do ministério.

A segunda faceta dos problemas de balanço patrimonial público nos gastos de pesquisa refere-se ao contigenciamento de verbas. Este é possivelmente o maior ralo pelo qual escoam os recursos, e o maior desafio enfrentado pelos defensores do FNDCT. Em 2005, a 'Frente Plurissetorial em Defesa da Ciência, Tecnologia e Inovação', grupo de parlamentares, membros do executivo e representantes da comunidade científica e do setor empresarial, publicou texto destacando sua preocupação com o problema do contingenciamento e falta de recursos daí decorrente. Um dos pontos altos do texto é a denúncia de que, mesmo com os fundos setoriais, o FNDCT não consegue atingir atualmente o seu pico histórico da década de setenta, quando o sistema de ciência e tecnologia brasileiro era cerca de vinte vezes maior (COGGIOLA, OLIVEIRA E PAIVA, 2006, p. 2). 
O contingenciamento é um expediente através do qual o governo federal, após a aprovação da lei orçamentária, limita ou bloqueia as despesas previstas no orçamento. Ele é realizado principalmente através de um decreto (chamado de Decreto de Contingenciamento), tendo por objetivo a adequação entre as receitas à disposição da União e suas despesas. Esta possibilidade se encontra prevista na Lei de Responsabilidade Fiscal. Juridicamente, trata-se de um artifício para apropriação dos recursos dos fundos setoriais, uma vez que, legalmente, eles não poderiam ser utilizados para outras finalidades.

A restrição dos investimentos do FNDCT via contingenciamento orçamentário passou por duas fases. Desde o seu início no ano de 1999 até 2002 a lei orçamentária autorizava a utilização integral das verbas dos fundos, mas o governo, ao longo do ano, restringia o seu empenho ${ }^{27}$ e utilização, contingenciando assim esses recursos. Entretanto, em 2002 a lei de diretrizes orçamentárias aprovada pelo Congresso Nacional para o ano seguinte estabeleceu que os recursos destinados à ciência e tecnologia não poderiam mais ser objeto de contingenciamento.

À luz dessa restrição, o que ocorreu a partir de então foi que o governo passou a inserir na própria proposta orçamentária enviada (e aprovada) pelo congresso uma "reserva de contingência", na qual eram alocadas parcela das verbas dos fundos setoriais. $\mathrm{Na}$ prática, o governo simplesmente antecipou a decisão de contingenciamento, que passou a ser tomada quando da apresentação e discussão do orçamento (que ocorre no ano anterior), ao invés de durante o ano corrente. (IEDI, 2005). Além disso, o ônus político da decisão de contingenciar recursos passou a ser dividido com os parlamentares, que são aqueles que aprovam o orçamento.

Feitos esses esclarecimentos, apresento no gráfico e tabela abaixo o impacto deste procedimento sobre os recursos de $\mathrm{P} \& \mathrm{D}$ dos fundos setoriais. Como minha atenção principal recai sobre o CT-Info, apresento também a série de dados deste "fundo", com a finalidade de analisar se o problema identificado para o FNDCT como um todo também se aplica a ele. Noto que, em função das duas fases acima expostas, o contingenciamento no

27 "O empenho de despesa é o ato emanado de autoridade competente que cria para o Estado obrigação de pagamento pendente ou não de implemento de condição" - artigo 58 da Lei 4.320/64 (Lei do Orçamento). 
período 1999-2002 foi calculado com base na diferença entre o volume total de recursos orçados e aqueles efetivamente empenhados (ou seja, tiveram sua execução autorizada, ainda que parcela deles não tenha efetivamente sido utilizada por outros motivos), enquanto no período seguinte utilizou-se o valor da reserva de contingência ${ }^{28}$.

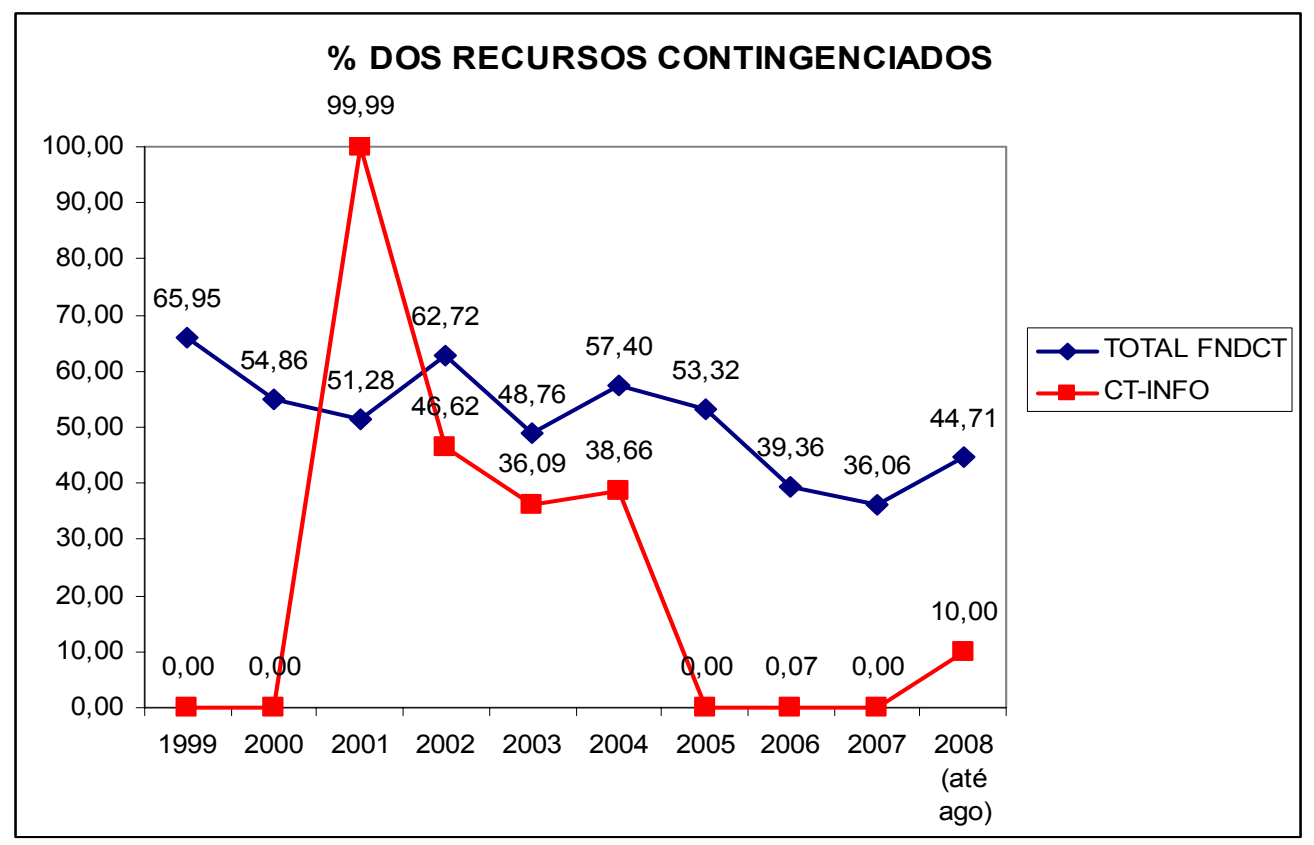

(Fonte: elaboração própria, com dados publicados pelo MCT com o orçamento dos fundos que compõem o FNDCT (Disponível em <www.mct.gov.br/index.php/ content/view/27181.html $>$. Acesso em 2.10.2008). Valores do Funttel estão excluídos.)

\begin{tabular}{|l|l|}
\hline \multicolumn{2}{|c|}{ Valores contingenciados CT-Info(*) } \\
\hline Ano & Valor $(\mathrm{R} \$)$ \\
\hline 2001 & 43.995 .684 \\
\hline 2002 & 18.630 .588 \\
\hline 2003 & 14.120 .000 \\
\hline 2004 & 11.976 .000 \\
\hline 2005 & 0 \\
\hline 2006 & 21.557 \\
\hline 2007 & 0 \\
\hline $\begin{array}{l}2008 \\
\text { agosto) }\end{array}$ & 3.668 .500 \\
\hline
\end{tabular}

(*) Valores não corrigidos.

Fonte: <www.mct.gov.br/index.php/content/view/

27181.html>. Acesso em 2.10.2008

\footnotetext{
${ }^{28}$ Esta forma de identificar o montante destinado a contingenciamento parece fazer sentido, uma vez que a partir de 2003, a diferença entre o total orçado e o efetivamente empenhado reduziu-se drasticamente, para menos de $10 \%$ no primeiro ano, e menos de 3\% nos seguintes (até 2007).
} 
Ainda que haja alguma divergência de menor valor com dados apresentados em outros estudos, estes números parecem confirmar o argumento de que a proposta de financiamento de projetos tecnológicos pelos fundos setoriais vem sendo seriamente comprometida pelo contingenciamento de receitas. Em diversos anos o valor contingenciado superou mesmo o valor efetivamente empenhado e investido (mais de $50 \%$ de contingenciamento).

Dessa forma, embora o potencial gerador de investimentos para pesquisa dos fundos setoriais apresente-se substantivo, esta oportunidade até o presente foi parcialmente desperdiçada pela tomada de grande parte de suas verbas. Não se pode dizer, assim, que tenha sido atingida a estabilidade e constância de recursos para C\&T, objetivo principal da instituição dos fundos. Conforme Pereira, "subtração de magnitude tal que se vem refletindo na perda de credibilidade de um dos principais atributos que justificaram a introdução da nova política - o de proporcionar estabilidade financeira aos programas de CT\&I" (Pereira, 2005, p. 33).

Quanto ao CT-Info, nota-se que, em geral, também sofreu os efeitos do contingenciamento de recursos, embora em menor grau do que o agregado dos fundos. Exceto pelo primeiro ano em que não foi utilizado quase nenhum recurso (possivelmente por problemas decorrentes da regulamentação e instituição do fundo), o CT-Info teve proporcionalmente menos recursos contingenciados, especialmente a partir de 2005, quando sua reserva de contingência foi a zero. Uma hipótese para explicar essa discrepância seja a pouca significância dos recursos desse fundo frente aos demais, o que talvez desperte menos interesse do governo em seu resguardo.

Uma última nota sobre este tema é que há uma promessa do governo Lula da Silva de encerrar por completo com o contingenciamento de recursos do FNDCT. A meta inicialmente traçada previa para 2010 o ano em que esse compromisso seria concretizado. Entretanto, o projeto de Lei de Diretrizes Orçamentárias para 2009 encaminhado pelo governo ao Congresso Nacional já antecipou essa medida, e não apresentou nenhuma reserva de contingência ${ }^{29}$.

29 Conforme notícia: FUNDOS setoriais de C\&T escapam de contingenciamento. Disponível em $<$ http://www.protec.org.br/noticias.asp?cod=2089>. Acesso em 10 jan. 2009. 
Apresentados os principais obstáculos à estratégia dos fundos setoriais e do CTINFO, cabe indagar qual seria a faceta jurídica de tais questões. No caso da utilização desses recursos para compensar uma retração de gastos do MCT destinados a C\&T, as fontes consultadas me pareceram trazer muito pouco desse lado nos debates. O problema, neste sentido, estaria muito mais ligado a uma decisão ou necessidade política (ou de finanças públicas), do que a uma falha no arcabouço institucional. Uma vez que os demais repasses a serem feitos ao ministério para incentivo à inovação não configuram receita vinculada constitucionalmente, nem há qualquer determinação legal que obrigue o governo a realizá-los, isto se torna, em última instância, uma decisão governamental de política pública, e não uma questão própria ou tecnicamente jurídica. No limite, não se poderia sequer dizer que se trata de um problema específico dos fundos setoriais, já que não estamos tratando de sua utilização, mas sim de como estão sendo alocados outros recursos, que antes eram destinados ao fomento tecnológico, e agora vêm servindo a outros propósitos.

O mesmo não se pode dizer do contingenciamento de verbas do CT-INFO. Conforme mencionado, a Lei de Informática exige que os recursos do fundo sejam destinados, exclusivamente, à promoção de projetos estratégicos de pesquisa e desenvolvimento em TI. A possibilidade de contingenciar esses valores revela a existência de uma falha, uma lacuna no conjunto normativo utilizada freqüentemente pelo governo federal para não obedecer a esta determinação legal. Há aqui, portanto, espaço para uma reforma legislativa que viesse a restringir ou regulamentar essa prática, para que o FNDCT como um todo pudesse cumprir de maneira mais adequada a função de financiamento a C\&T que levou a sua criação.

Noto que as recentes notícias de que o atual governo federal não pretende realizar novos contingenciamentos parece uma solução muito pouco satisfatória do ponto de vista jurídico, uma vez que se trata de uma postura política que poderá não ser mantida futuramente. Desta forma, a garantia de que esses recursos serão efetivamente utilizados consoante seu objetivo inicial parece mesmo demandar uma alteração normativa, idealmente no plano legal (o que retiraria as decisões de contingenciamento do controle do Poder Executivo). 
À luz de todo o analisado, pode-se dizer que o CT-INFO (no conjunto dos demais fundos setoriais) parece constituir um instrumento jurídico de financiamento à inovação que vem ganhando grande importância. No entanto, sujeito ao contingenciamenteo, ele apresenta uma fragilidade institucional, na medida em que o governo pode, virtualmente, apropriar-se ou interromper o fluxo de recursos através da manobra do contingenciamento, o que compromete o próprio objetivo da constituição dos fundos setoriais, que era garantir a estabilidade e a constância desses recursos.

\subsection{Instrumentos jurídicos relevantes da política de informática}

A partir das análises realizadas, retomo a afirmação feita no início deste capítulo, de que a política de informática não pode ser compreendida como um único instrumento de política pública setorial, ou mesmo um bloco esparso e desconexo de regras e incentivos. Ao contrário, ela constitui um plexo de ações, que, em uma ação pretensamente conjunta e coordenada, tenta alterar a estrutura produtiva do setor. Neste capítulo expus três frentes ou grupos de objetivos ${ }^{30}$. Tento resumir na tabela abaixo os principais achados e conclusões acerca de cada um, à luz dos critérios que estabeleci no início deste capítulo, permitindo uma visualização rápida e comparativa dos três instrumentos.

\begin{tabular}{|c|c|c|c|}
\hline \multicolumn{4}{|c|}{ INSTRUMENTOS JURÍDICOS DA POLÍTICA DE INFORMÁTICA } \\
\hline & PPB & P\&D & CT-INFO \\
\hline $\begin{array}{l}\text { Problema a ser } \\
\text { enfrentado/ } \\
\text { razão de } \\
\text { criação da } \\
\text { ferramenta }\end{array}$ & $\begin{array}{l}\text { Perda ou destruição da } \\
\text { capacidade tecnológica e do } \\
\text { parque de empresas } \\
\text { instaladas com a abertura de } \\
\text { mercado. }\end{array}$ & $\begin{array}{l}\text { Redução dos gastos } \\
\text { com pesquisa após a } \\
\text { abertura - inovação } \\
\text { deixa de ser central nas } \\
\text { estratégias de negócios. }\end{array}$ & $\begin{array}{l}\text { Instabilidade e falta de } \\
\text { constância dos recursos } \\
\text { destinados a C\&T. }\end{array}$ \\
\hline $\begin{array}{l}\text { Racionalidade } \\
\text { da política } \\
\text { para atacar o } \\
\text { problema }\end{array}$ & $\begin{array}{l}\text { Concessão de incentivos } \\
\text { fiscais à produção local. }\end{array}$ & $\begin{array}{l}\text { Conjugação } r \text { de } \\
\text { incentivo fiscal e } \\
\text { contrapartida de gastos } \\
\text { em P\&D } \\
\text { financiamento público } \\
\text { de projetos empresariais } \\
\text { de inovação. }\end{array}$ & $\begin{array}{l}\text { CT-Info: apropriação de } \\
10 \% \text { dos investimentos } \\
\text { exigidos em P\&D. } \\
\text { Financiamento de projetos } \\
\text { de inovação de interesse } \\
\text { público (novos pólos } \\
\text { tecnológicos e capital- } \\
\text { semente). }\end{array}$ \\
\hline $\begin{array}{l}\text { Função do } \\
\text { direito dentro } \\
\text { dessa } \\
\text { racionalidade }\end{array}$ & $\begin{array}{l}\text { Indutor/Premiador: distor- } \\
\text { ção do sistema de preços em } \\
\text { benefício da produção } \\
\text { interna. }\end{array}$ & $\begin{array}{l}\text { Amarração institucional } \\
\text { do financiamento. }\end{array}$ & Garantidor de recursos. \\
\hline $\begin{array}{l}\text { Principal } \\
\text { núcleo } \\
\text { normativo que } \\
\text { descreve o } \\
\text { instrumento } \\
\end{array}$ & $\begin{array}{l}\text { Portarias Interministeriais } \\
\text { que fixam o PPB }\end{array}$ & $\begin{array}{l}\text { Decreto } \\
\text { regulamentação }\end{array}$ & Lei de Informática \\
\hline
\end{tabular}

\footnotetext{
${ }^{30}$ Noto que a lei estabelece outros pontos e objetivos a serem atingidos, como as certificações de qualidade e as exigências de dispersão geográfica dos incentivos.
} 


\begin{tabular}{|c|c|c|c|}
\hline \multicolumn{4}{|c|}{ INSTRUMENTOS JURÍDICOS DA POLÍTICA DE INFORMÁTICA } \\
\hline & PPB & P\&D & CT-INFO \\
\hline $\begin{array}{l}\text { Evolução do } \\
\text { arcabouço } \\
\text { normativo }\end{array}$ & $\begin{array}{l}\text { (i) Instrumento de fácil } \\
\text { adaptação e transformação - } \\
\text { sob controle da burocracia; } \\
\text { (ii) aprendizado - abandono } \\
\text { de obrigações inaplicáveis } \\
\text { ou ligadas à política } \\
\text { anterior, outsorcing; e } \\
\text { (iii) legislação posterior } \\
\text { apresenta maior precisão e } \\
\text { densidade técnica. }\end{array}$ & $\begin{array}{l}\text { (i) Detalhamento e } \\
\text { sistematização das } \\
\text { regras; } \\
\text { (ii) regionalização dos } \\
\text { recursos a serem } \\
\text { aplicados; e } \\
\text { (iii) introdução do CT- } \\
\text { Info. }\end{array}$ & $\begin{array}{l}\text { Não houve evolução } \\
\text { normativa relevante. }\end{array}$ \\
\hline $\begin{array}{l}\text { Sucessos e bons } \\
\text { resultados } \\
\text { obtidos }\end{array}$ & $\begin{array}{l}\text { Limitou o processo de } \\
\text { substituição da fabricação } \\
\text { local por aquisição externa } \\
\text { no segmento final da cadeia } \\
\text { produtiva }\end{array}$ & $\begin{array}{l}\text { (i) Retomada dos gastos } \\
\text { com pesquisa no setor; } \\
\text { (ii) instalação de } \\
\text { centros de pesquisa de } \\
\text { empresas multina- } \\
\text { cionais no país; e } \\
\text { (iii) instituições de } \\
\text { ensino e pesquisa foram } \\
\text { beneficiadas com } \\
\text { convênios e recursos. }\end{array}$ & $\begin{array}{l}\text { (i) Trouxe aporte de } \\
\text { recursos (ausência de } \\
\text { crowding-out); } \\
\text { (ii) financiamento de } \\
\text { incubadoras de empresas, } \\
\text { capacitação de recursos } \\
\text { humanos e fomento de } \\
\text { grupos acadêmicos; e } \\
\text { (iii) regionalização de } \\
\text { financiamentos. }\end{array}$ \\
\hline $\begin{array}{l}\text { Limites e } \\
\text { problemas da } \\
\text { ferramenta }\end{array}$ & $\begin{array}{l}\text { (i) Produção não regio- } \\
\text { nalizada; e } \\
\text { (ii) não obteve êxito em } \\
\text { manter indústria de } \\
\text { componentes, ou em } \\
\text { internalizar etapas } \\
\text { produtivas mais densas. }\end{array}$ & $\begin{array}{l}\text { Problemas de } \\
\text { institucional } \\
\text { funcionamento } \\
\text { instrumento): } \\
\text { hiato entre renúncia e } \\
\text { P\&D, e destinação } \\
\text { inapropriada } \\
\text { recursos. }\end{array}$ & $\begin{array}{l}\text { (i) Recursos compensam } \\
\text { uma retração de gastos } \\
\text { com C\&T; e } \\
\text { (ii) contingenciamento de } \\
\text { verbas } \\
\text { institucional). }\end{array}$ \\
\hline
\end{tabular}

A partir desta tabela é possível compreender que a política de informática, ao longo de sua evolução no período aqui relatado, buscou atacar diferentes problemas ou situações fáticas que, consoante uma lógica não puramente neoclássica ou neo-utilitarista, impediam o crescimento e a competitividade desta indústria. As racionalidades utilizadas para enfrentar essas questões foram diversas conforme cada caso, embora todas pareçam confiar significativamente em ferramentas jurídicas em uma estratégia para alterar ou complementar os investimentos realizados conforme o sistema de preços de mercado.

O papel específico representado pelo direito como estrutura normativa em cada uma dessas ferramentas também diferiu, o que revela uma riqueza e complexidade da política de informática enquanto conjunto de mecanismos para o desenvolvimento setorial. Nos três casos o direito parece ter funcionado como um instrumento de política industrial, nos moldes pensados por Duncan Kennedy para a " $2^{\mathrm{a}}$ Globalização", ou o “Intervencionismo modesto" de David Kennedy ${ }^{31}$. Desta forma, a política de informática

\footnotetext{
${ }^{31}$ Conforme a seção "Política Industrial e Direito” em minhas Considerações Iniciais.
} 
me leva à conclusão de que, nos dois casos, embora o momento ou tempo típico desse tipo de política possa ter passado, algumas características e ferramentas estruturadas nesses termos foram enraizadas no tecido jurídico, e permanecem sendo utilizadas contemporaneamente.

Um outro aspecto que já havia sido exposto, mas pôde ser ilustrado melhor neste capítulo é a evolução do conjunto normativo da política pública ao longo de sua implementação. Esta evolução deveu-se, de um lado, à melhoria e processo de revisão interna da política, na tentativa de solucionar problemas e melhorar procedimentos. Em segundo lugar, houve também a influência do desenvolvimento próprio de outras medidas de ação estatal inicialmente não relacionadas à política de informática, mas que acabaram por incorporar novos objetivos e instrumentos, através dos fundos setoriais e do CT-Info.

Outro ponto relevante sobre a evolução da política é a conjugação entre a evolução da ferramenta jurídica e o tipo de norma responsável por sua descrição ou detalhamento. Neste ponto o contraste entre o PPB e o CT-Info é especialmente revelador. O PPB constitui um instrumento que demanda maior dinâmica e rapidez em sua alteração, seja para aprovar novos processos produtivos e abarcar novos equipamentos no âmbito da política, seja para alterar os processos já existentes, ou para incorporar aprendizados e práticas da indústria. Por esse motivo, parece fazer sentido que a explicitação deste instrumento se dê através de Portarias Interministeriais do Poder Executivo, que podem ser alteradas sem maiores formalidades.

Não é esse o caso do CT-Info, cuja criação tinha por principal objetivo garantir um fluxo de recursos para projetos de C\&T. O que importa aqui é a estabilidade e certeza de que tais verbas não seriam utilizadas para outros fins pelo governo federal. Assim, fazia sentido cristalizar a descrição desta regra (inclusive por sua pouca complexidade) em uma lei, que demanda aprovação do Congresso Nacional para alteração.

Os momentos de revisão e evolução da política também revelam uma conclusão interessante. As alterações mais significativas foram realizadas em 2001 e 2004, em grande parte tendo por principal motivação a renovação dos incentivos, cuja validade havia vencido ou iria se encerrar nos próximos anos. Por esse motivo, pode-se argumentar que na ausência dessas extensões através de novas leis algumas das novidades posteriores da 
política poderiam não ter sido introduzidas. Nesse sentido, a sua temporaneidade acabou por funcionar como um elemento dinamizador, que permitiu não apenas a continuação da política, como também a reflexão e solução de alguns de seus problemas.

Voltando às perguntas formuladas no início do capítulo, a análise dos impactos e resultados gerados pelos instrumentos jurídicos estudados parece apontar para uma intervenção positiva, ainda que limitada, do Estado através desta política setorial, intervenção essa na qual o direito público, em sua interface com relações privadas, teve papel decisivo. Por meio do PPB se obteve êxito em alterar o cálculo empresarial e estancar parcialmente a transferência da produção interna de bens eletrônicos de informática para a importação, ao menos no que se refere aos bens finais. As contrapartidas em P\&D, ainda que com problemas, foram cumpridas pelas empresas, que investiram recursos em projetos de inovação tecnológica, sendo relevantes ainda para levar o país ao mapa mundial de investimentos em tecnologia de grandes conglomerados globais. Já o CTInfo vem financiando projetos importantes para integração e promoção do setor, além de ter aportado novos recursos para $\mathrm{P} \& \mathrm{D}$, ainda que limitado pelo contingenciamento.

A experiência da política de informática e seus desdobramentos revelam portanto um potencial sentido e importância para uma intervenção do Estado que transcende as políticas horizontais ou simplesmente a correção de falhas de mercado. Neste sentido, são medidas que, com as devidas alterações, podem ser replicadas ou servir de inspiração para a intervenção em setores econômicos de importância estratégica e alta dinâmica tecnológica.

Por outro lado, todas essas tentativas encontraram também fortes limitações, que as impediram de desencadear efeitos mais substanciais. Este estudo revelou limites derivados de três fontes: em parte eles derivam de fatores exógenos e fora do controle dos agentes públicos e policy-makers - trata-se do fracasso do PPB em gerar incentivos (e obrigações correspondentes) capazes de manter ou estabelecer uma indústria de componentes, cuja ausência de escala do mercado nacional terminou por inviabilizar.

Em outras situações os problemas são intrínsecos à política e à burocracia responsável, decorrentes de falhas em sua formulação ou da ausência de coordenação com o setor privado (ou ainda da incompatibilidade dos interesses deste com os objetivos da 
política), o que pode sinalizar a necessidade de um trabalho de revisão das normas ou convencimento dos agentes envolvidos. As dificuldades e o longo tempo que o MCT tomava para analisar os relatórios de gastos em P\&D das empresas nos anos noventa são problemas desse tipo, assim como os subterfúgios utilizados por parcela das firmas para, de alguma forma, reduzir ou internalizar esses recursos, diminuindo de qualquer forma os seus gastos com pesquisa.

Por fim, os problemas podem ser externos à política, mas decorrerem da incompatibilidade com outras políticas públicas ou decisões governamentais. A disputa com a ZFM (descrita no capítulo anterior) é um exemplo. Também o são as decisões de contingenciamento de recursos do FNDCT, que frustraram parte da promessa representada pelos fundos setoriais de maior injeção e estabilidade nos investimentos em ciência e tecnologia.

Feitas essas considerações, concluo minha análise dos instrumentos jurídicos que compõem a atual política de informática. Conforme tentei demonstrar, trata-se de uma estrutura normativa complexa, na qual o direito tem um importante papel dentro das racionalidades instituídas para solucionar os problemas ou atingir os objetivos determinados. Assim, resta conjugar esta análise com as conclusões e elementos estudados nos capítulos anteriores, a partir dos marcos teóricos identificados nas considerações iniciais e no capítulo 1 , e também dos fatos e narrativa dos capítulos 2 e 3 , que permitem compreender as dinâmicas política e econômica que forjaram a atual política. Isto será realizado na próxima parte, onde retomo as perguntas formuladas no início desta dissertação, à luz de todo o estudado até aqui. 


\section{CONCLUSÕES E LIÇÕES DO ESTUDO}

Nesta etapa final retorno à pergunta de pesquisa formulada no início desta dissertação, tentando evidenciar como a pesquisa realizada ajudou a respondê-la ou, ao menos, a fornecer pistas para sua solução. Para tanto, retomo as principais hipóteses e lições de cada capítulo, entrelaçando-as. Trata-se, enfim, de perguntar como pode ser descrito o papel do direito no bojo da estratégia de uma política industrial voltada a uma indústria de grande relevância e com externalidades positivas para o restante da economia como o setor de informática e TI, especialmente no novo contexto econômico e político em que o Estado desenvolvimentista do pós-guerra (ou consoante as definições e classificações correlatas de Duncan Kennedy e David Kennedy, já apresentadas antes) e suas promessas encontram-se ao menos em parte superados, estando a economia brasileira aberta à concorrência internacional após as reformas dos anos noventa.

Conforme descrito na parte introdutória, tento responder a essa questão não em termos genéricos e abstratos, mas analisando como se deu, em um caso concreto e um dado momento histórico, a colaboração estatal para a criação, estruturação e amadurecimento de um mercado de informática no Brasil. Assim, a questão resume-se a entender qual foi a importância efetiva de uma política industrial setorizada para esta indústria, e, principalmente, como o direito - o arcabouço jurídico em um sentido amplo - colaborou e/ou foi instrumentalizado dentro dessa lógica.

Dividirei a resposta em três partes que, embora interligadas, podem ser artificialmente separadas para fins de análise. Inicialmente, tratarei da importância do direito para a evolução do trajeto da política de informática no Brasil (compreendendo a antiga política e a atual), e para as estratégias adotadas pelo setor público, partindo das narrativas históricas realizadas nos capítulos 2 e 3 . Noto que aqui o mais importante é analisar os impactos sobre o desenrolar da própria política. Na segunda parte o objetivo será olhar o papel exercido pela estrutura jurídica dentro da racionalidade de política pública pretendida para a Lei de Informática, retomando assim as conclusões do capítulo 4. Por fim, tentarei fazer um exercício em termos mais abstratos, apresentando esquematicamente como o direito e a política de informática foram em grande parte 
responsáveis pela estruturação do mercado de informática no país, na medida em que foram, paulatinamente, superando problemas e criando condições para o desenvolvimento do setor.

Quanto à primeira tarefa, parto da premissa de que há uma estreita relação de influência mútua entre o direito e a política pública concebida, ou seja, que esta é determinada e limitada pelo ordenamento jurídico e pelas normas que a concretizam. Do mesmo modo, o elemento jurídico é influenciado permanentemente pelos rumos da política pública. Esta percepção possui evidente relação com a abordagem evolucionária ou neoschumpeteriana, uma vez que a política pública em questão é vislumbrada como um processo dinâmico, que evolui como resposta aos desafios e possibilidades criadas no momento anterior, e como resultado de uma série de fatores que as influenciam, dentre os quais o quadro institucional. Desta forma procuro também confirmar minha conclusão extraída do primeiro capítulo, de que este ramo da teoria econômica - contrariamente às leituras mais ortodoxas - apresenta uma maior abertura ao diálogo e possibilidade de interpenetração com a pesquisa empírica realizada no campo do direito.

$\mathrm{Na}$ tabela abaixo enumero os principais aspectos e características estudadas dos momentos da política pública de incentivo à informática no Brasil. A tabela mostra as principais diferenças existentes entres os modelos adotados ao longo do tempo, enfatizando o contexto de sua formulação inicial, os instrumentos forjados e utilizados para cada um desses contextos, e as características e problemas de cada período. A idéia aqui, além do exercício proposto de compreender o papel do direito e do arcabouço normativo no evolver da política, é aproveitar para resumir em um único esquema os principais pontos que julguei relevantes em todo o estudo empírico realizado, mostrando a cadeia evolutiva dessa política, em que cada momento prestou sua contribuição para os rumos tomados no período seguinte.

Considerando a complexidade e o desenvolvimento tanto da antiga política como da atual Lei de Informática, entendi ser conveniente subdividir cada uma dessas etapas em duas, que vão refletir a respectiva primeira subfase inicial, em que o aspecto da formulação esteve mais presente, e a segunda, na qual emergem elementos de crise ou reformulação do cenário anterior. 
TABELA COMPARATIVA DOS MOMENTOS DA POLÍTICA DE INFORMÁTICA NO BRASIL

\begin{tabular}{|c|c|c|c|c|c|c|c|c|}
\hline & $\begin{array}{l}\text { Principal } \\
\text { arcabouço } \\
\text { teórico }\end{array}$ & $\begin{array}{l}\text { Contexto econômico- } \\
\text { político da formulação } \\
\text { inicial }\end{array}$ & $\begin{array}{c}\text { Atores e } \\
\text { instituições } \\
\text { políticas } \\
\text { relevantes }\end{array}$ & $\begin{array}{c}\text { Principais } \\
\text { normas de } \\
\text { implementação }\end{array}$ & $\begin{array}{l}\text { Instrumentos } \\
\text { relevantes } \\
\text { utilizados }\end{array}$ & Resultados & Características e Problemas & $\begin{array}{c}\text { Influência e papel } \\
\text { do direito para a } \\
\text { política e sua } \\
\text { evolução }\end{array}$ \\
\hline $\begin{array}{l}1^{\circ} \text { momento } \\
\text { da antiga } \\
\text { Política } \\
\text { Nacional de } \\
\text { Informática } \\
(1972-1979)\end{array}$ & $\begin{array}{l}\text { CEPAL } \\
\text { (estrutura- } \\
\text { lismo } \\
\text { histórico); e } \\
\text { indústria } \\
\text { infante (F. } \\
\text { List). }\end{array}$ & $\begin{array}{l}\text { Internacional: } \\
\text { (i) Surgimento da } \\
\text { indústria de informática } \\
\text { no mundo; (ii) Choques } \\
\text { do petróleo; e } \\
\text { (iii) Lançamento dos } \\
\text { minis rerar e } \\
\text { microcomputadores. } \\
\text { Nacional: } \\
\text { (i) Equipamentos } \\
\text { militares - problemas } \\
\text { com a dependência } \\
\text { tecnológica; (ii) } \\
\text { Engenheiros eletrônicos } \\
\text { sem campo para } \\
\text { desenvolver pesquisas; } \\
\text { (iii) Necessidade de } \\
\text { gestão da burocracia } \\
\text { governamental; e (iv) } \\
\text { Mercado de minis e } \\
\text { micros ainda em } \\
\text { ocupação. }\end{array}$ & 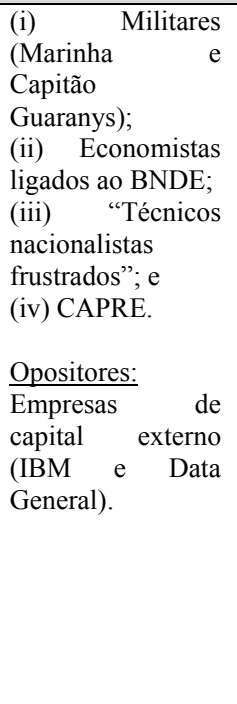 & $\begin{array}{l}\text { Resolução } \\
\text { CONCEX 104; } \\
\text { Decreto } \\
77.118 / 76 ; \text { e } \\
\text { Resolução } 5 / 77 \\
\text { CDE. }\end{array}$ & $\begin{array}{l}\text { (i) CAPRE recebe } \\
\text { controle sobre } \\
\text { importações de } \\
\text { peças } \quad \text { e } \\
\text { componentes; } \\
\text { (ii) Critérios para } \\
\text { declaração de } \\
\text { prioridade; e } \\
\text { (iii) Licitação dos } \\
\text { minis. }\end{array}$ & $\begin{array}{l}\text { Pontos positivos: } \\
\text { (i) Geração de uma indústria } \\
\text { local - firmas produtoras de } \\
\text { equipamentos; } \\
\text { (ii) Desenvolvimento de } \\
\text { recursos humanos e capacitação } \\
\text { tecnológica; } \\
\text { (iii) Geração de altos recursos } \\
\text { para P\&D; e } \\
\text { (iv) Setor de automação } \\
\text { bancária. } \\
\text { Pontos negativos: } \\
\text { (i) Ausência de metas favoreceu } \\
\text { racionalidade oportunista - } \\
\text { proteção incentivava } \\
\text { acomodação dos agentes e não } \\
\text { inovação; } \\
\text { (ii) Preços altos comparado com } \\
\text { mercado externo; } \\
\text { (iii) Falta de seletividade da } \\
\text { política - exigia investimento em }\end{array}$ & $\begin{array}{l}\text { (i) Fragilidade institucional: órgãos } \\
\text { competindo pelo controle da política; } \\
\text { e } \\
\text { (ii) Fragilidade da aliança entre grupos } \\
\text { de suporte - permitiu a tomada da } \\
\text { política por um órgão politicamente } \\
\text { forte, levando à emergência de um } \\
\text { novo modelo ( } 2^{\circ} \text { momento). }\end{array}$ & $\begin{array}{lrr}\text { Ausência } & \text { de } \\
\text { regulamentação } & \\
\text { estrita } & \text { permitiu } \\
\text { primeiras } & \text { ações } & \text { de } \\
\text { proteção, } & \text { dando } \\
\text { flexibilidade } & \text { a } \\
\text { CAPRE e } & \text { demais } \\
\text { órgãos } & & \text { para } \\
\text { estabelecimento } & \text { de } \\
\text { regras. } & & \end{array}$ \\
\hline $\begin{array}{l}2^{\circ} \text { momento } \\
\text { da antiga } \\
\text { Política } \\
\text { Nacional de } \\
\text { Informática } \\
(1979-1991)\end{array}$ & & $\begin{array}{l}\text { (i) "Militarização" da } \\
\text { política pública por } \\
\text { interesses do SNI e } \\
\text { MRE, e desconfiança } \\
\text { com os "guerrilheiros } \\
\text { tecnológicos"; (ii) } \\
\text { Redemocratização; e } \\
\text { (iii) críticas à política e } \\
\text { disputa comercial com } \\
\text { os EUA. }\end{array}$ & $\begin{array}{l}\text { (i) MRE; } \\
\text { (ii) SNI; e } \\
\text { (iii) SEI. } \\
\text { Opositores: } \\
\text { (i) Economistas de } \\
\text { inspiração liberal } \\
\text { (Roberto } \\
\text { Campos); e } \\
\text { (ii) Empresas e } \\
\text { governo dos EUA } \\
\text { (disputa } \\
\text { comercial). }\end{array}$ & $\begin{array}{l}\text { Decreto } \\
84.067 / 79 ; \\
\text { antiga Lei de } \\
\text { Informática } \\
(7.232 / 84) .\end{array}$ & $\begin{array}{l}\text { (i) Reserva de } \\
\text { mercado } \\
\text { controle completo } \\
\text { de importações; e } \\
\text { (ii) Licitação dos } \\
\text { superminis. }\end{array}$ & $\begin{array}{l}\text { diversos segmentos } \\
\text { encarecimento do preço dos } \\
\text { produtos; } \\
\text { (iv) Falta de aporte de recursos } \\
\text { públicos mais agressivos; e } \\
\text { (v) Falta de parâmetro no } \\
\text { mercado externo - meta de } \\
\text { competitividade internacional. }\end{array}$ & $\begin{array}{l}\text { (i) Órgão centralizador de grande } \\
\text { força política (SEI) soluciona } \\
\text { problemas de articulação. Maior poder } \\
\text { regulatório; } \\
\text { (ii) SEI passou a ser identificada como } \\
\text { braço do CSN (autoritarismo); } \\
\text { (iii) Ascensão de ideologia liberal; } \\
\text { (iv) "Redefinição do quadro de } \\
\text { lealdades" (empresas nacionais criam } \\
\text { laços com estrangeiras); e } \\
\text { (v) itens (ii), (iii) e (iv) representam o } \\
\text { esgotamento do modelo, que levam ao } \\
\text { surgimento da nova política na década } \\
\text { de noventa. }\end{array}$ & 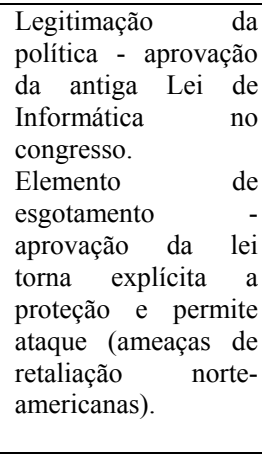 \\
\hline
\end{tabular}




\begin{tabular}{|c|c|c|c|c|c|c|c|c|}
\hline & $\begin{array}{l}\text { Principal } \\
\text { arcabouço } \\
\text { teórico }\end{array}$ & $\begin{array}{l}\text { Contexto econômico- } \\
\text { político da formulação } \\
\text { inicial }\end{array}$ & $\begin{array}{c}\text { Atores e } \\
\text { instituições } \\
\text { políticas } \\
\text { relevantes }\end{array}$ & $\begin{array}{c}\text { Principais } \\
\text { normas de } \\
\text { implementação }\end{array}$ & $\begin{array}{l}\text { Instrumentos } \\
\text { relevantes } \\
\text { utilizados }\end{array}$ & Resultados & Características e Problemas & $\begin{array}{l}\text { Influência e papel } \\
\text { do direito para a } \\
\text { política e sua } \\
\text { evolução }\end{array}$ \\
\hline $\begin{array}{l}1^{\circ} \text { momento } \\
\text { da Lei de } \\
\text { Informática } \\
(1991-2001)\end{array}$ & $\begin{array}{l}\text { Conjugação } \\
\text { de elementos } \\
\text { neoclássicos } \\
\text { (abertura de } \\
\text { mercado) e } \\
\text { neoschum- } \\
\text { peterianos. }\end{array}$ & $\begin{array}{l}\text { (i) Problemas macro- } \\
\text { econômicos - hiper- } \\
\text { inflação; (ii) Planos de } \\
\text { estabilização; (iii) Neo- } \\
\text { liberalismo e Consenso } \\
\text { de Washington; (iv) } \\
\text { Esgotamento da política } \\
\text { anterior; e (v) debate } \\
\text { sobre transição (gra- } \\
\text { dualismo x ruptura } \\
\text { imediata). }\end{array}$ & $\begin{array}{l}\text { (i) } \mathrm{SCT} \text {; e } \\
\text { (ii) Associações } \\
\text { do setor } \\
\text { (ABICOMP). } \\
\text { Opositores: } \\
\text { e nEFP } \\
\text { e núcleo do } \\
\text { governo vinculado } \\
\text { ao projeto de } \\
\text { abertura de de } \\
\text { mercado. }\end{array}$ & $\begin{array}{l}\text { (i) Lei de } \\
\text { Informática } \\
\text { (8.248/91); } \\
\text { (ii) Decreto } \\
\text { 792/93; e } \\
\text { (iii) Portaria } \\
\text { MCT/MICT } \\
\text { 101/93. }\end{array}$ & $\begin{array}{l}\text { (i) Redução fiscal } \\
\text { (IPI); Redução } \\
\text { (ii) Redisal para } \\
\text { fiscal } \\
\text { investimento em } \\
\text { empresas de } \\
\text { informática (IR); } \\
\text { (iii) Redução } \\
\text { fiscal para } \\
\text { investimento em } \\
\text { P\&D (IR); } \\
\text { (iv) PPB; } \\
\text { (v) Contrapartida } \\
\text { em P\&D; } \\
\text { (vi) Compras } \\
\text { governamentais; e } \\
\text { (viii) programas } \\
\text { prioritários. }\end{array}$ & $\begin{array}{l}\text { Pontos positivos: } \\
\text { (i) Amplo alcance - beneficiou } \\
\text { grande número de empresas do } \\
\text { setor; } \\
\text { (ii) Colaborou para o } \\
\text { aproveitamento do bom } \\
\text { momento do setor na década de } \\
90 ; \\
\text { (iii) Manutenção de parte da } \\
\text { estrutura de produção e } \\
\text { capacitação tecnológica } \\
\text { constrúdas no período anterior; } \\
\text { (iv) Impediu que o déficit } \\
\text { comercial se lastrasse para o } \\
\text { segmento de bens finais de } \\
\text { informática; } \\
\text { (v) Colaborou para diminuição } \\
\text { de preços e inclusão digital; e }\end{array}$ & $\begin{array}{l}\text { (i) Aceitação e amplo alcance da nova } \\
\text { política por empresas do setor; } \\
\text { (ii) Fragilidade da indústria após a } \\
\text { abertura - necessidade de renovação } \\
\text { do prazo inicial da política; e } \\
\text { (iii) Incertezas e sinalizações } \\
\text { contraditórias do governo na } \\
\text { condução da discussão da política, e } \\
\text { no seu processo de } 1^{\text {a }} \text { renovação, } \\
\text { gerando ambiente de incerteza no } \\
\text { setor privado. }\end{array}$ & $\begin{array}{l}\text { Lei não determinou } \\
\text { estritamente regras e } \\
\text { critérios da política, } \\
\text { dando espaço à } \\
\text { burocracia } \\
\text { especializada. } \\
\text { Questões de } \\
\text { coerência interna do } \\
\text { ordenamento jurídico } \\
\text { afetaram } \\
\text { instrumentos da } \\
\text { política (alteração da } \\
\text { ordem constitucional } \\
\text { em 1995). }\end{array}$ \\
\hline $\begin{array}{l}2^{\circ} \text { momento } \\
\text { da Lei de } \\
\text { Informática } \\
\text { (2001- } \\
\text { presente) }\end{array}$ & $\begin{array}{l}\text { Renovação } \\
\text { de elementos } \\
\text { neoschum- } \\
\text { peterianos. }\end{array}$ & $\begin{array}{l}\text { (i) Encerramento do } \\
\text { prazo inicial da política; } \\
\text { (ii) Tentativa de } \\
\text { legitimação da con- } \\
\text { tinuidade através da } \\
\text { divulgação de resul- } \\
\text { tados; (iii) Oposição dos } \\
\text { parlamentares pró-ZFM; } \\
\text { e (iv) Urgência na } \\
\text { renovação devido à } \\
\text { decisão do STF. }\end{array}$ & 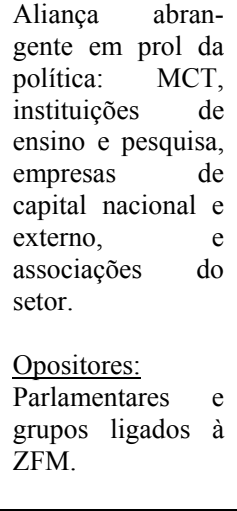 & 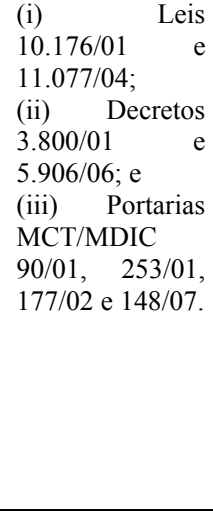 & $\begin{array}{l}\text { (i) Redução fiscal } \\
\text { (IPI); } \\
\text { (ii) PPB; } \\
\text { (iii) Contrapartida } \\
\text { em P\&D; } \\
\text { (iv) Compras } \\
\text { governamentais; } \\
\text { (v) Incentivo } \\
\text { maior para } \\
\text { produto } \\
\text { desenvolvido no } \\
\text { país; programas } \\
\text { (vi) prioritários; } \\
\text { (vii) FNDCT } \\
\text { (CT-Info). }\end{array}$ & $\begin{array}{l}\text { (vi) Instrumento de combate ao } \\
\text { mercado cinza. } \\
\text { Pontos negativos: } \\
\text { (i) Não preservou empregos na } \\
\text { indústria; } \\
\text { (ii) Não foi capaz de, } \\
\text { isoladamente, manter ou } \\
\text { incentivar uma indústria de } \\
\text { componentes; e } \\
\text { (iii) Indústria majoritariamente } \\
\text { voltada ao mercado interno - } \\
\text { política não conteve o déficit na } \\
\text { balança comercial decorrente da } \\
\text { importação maciça de partes e } \\
\text { componentes, dentre outros. }\end{array}$ & $\begin{array}{l}\text { (i) Superação do debate teórico- } \\
\text { ideológico; } \\
\text { (ii) Rumos e lógica influenciados pela } \\
\text { disputa com ZFM; } \\
\text { (iii) Consolidação da política pública e } \\
\text { resolução de problemas pontuais } \\
\text { (regionalização dos recursos de P\&D, } \\
\text { redução de incertezas e fraudes e } \\
\text { discussão sobre débitos atrasados); } \\
\text { (iv) Retomada de incentivos ao } \\
\text { desenvolvimento local; e } \\
\text { (v) Captura de parcela dos recursos de } \\
\text { P\&D pelo poder público - FNDCT. }\end{array}$ & 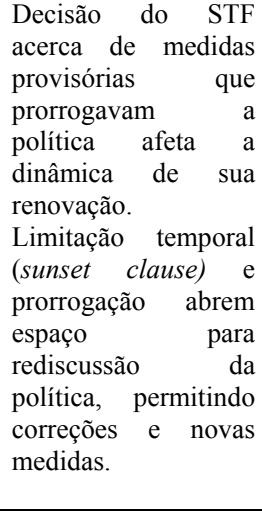 \\
\hline
\end{tabular}


Acredito que esta tabela resuma os principais aspectos empíricos da pesquisa descrita nos capítulos anteriores. A antiga política de informática foi constituída em um momento especialmente importante pelo qual passava a indústria mundial e o mercado brasileiro. Por um lado, era um setor relativamente jovem, cujas potencialidades tecnológicas se renovavam a cada momento (a Lei de Moore), o que havia levado alguns países (especialmente os mais desenvolvidos) a fixarem políticas para esta indústria estratégica, garantindo sua parcela no mercado. Por outro, a constante revolução desta tecnologia permitiu o lançamento dos mini e microcomputadores, cuja dinâmica de mercado e principais atores ainda estavam indefinidos no Brasil, o que representava uma janela de oportunidade para as empresas locais. Há ainda que se considerar um elemento não relacionado propriamente à indústria, a crise internacional dos anos setenta, que veio justificar o controle de importações e os desenvolvimentos posteriores da política.

Assim como a combinação desses elementos foi fundamental para o desenrolar do primeiro momento da antiga política, também o foi a conjugação de grupos de interesse bem distintos em torno da política. A união entre militares, técnicos e economistas de inspiração desenvolvimentista formou uma forte base de sustentação que permitiu a adoção de medidas que contrariavam interesses externos e internos. Mas a instabilidade dessa aliança e a falta de articulação política entre os órgãos responsáveis foram também causadores da derrocada do primeiro momento calcado no modelo CAPRE, passando a política a ser comandada diretamente pelo governo e pelos militares através da SEI.

O grande interesse no estudo da antiga política de informática repousa sobre o fato de que ela parece confirmar os benefícios dessa estratégia para o momento econômico que o país vivia à época (e que dificilmente pode ser reproduzido após a abertura de mercado subseqüente), assim como de uma política industrial setorial e focada, ao mesmo tempo em que evidencia os aspectos negativos dessa escolha. Com efeito, o protecionismo também acabou por gerar rent-seeking e aproveitamento oportunista dos incentivos governamentais, com a criação de um parque industrial pouco eficiente, com preços altos e sem grandes condições de concorrência no mercado externo.

Quanto ao papel desempenhado pelo direito e o arcabouço institucional para a evolução da antiga política, pode-se dizer que tenha passado por três principais etapas. Em um primeiro momento, a lacuna ou ausência de uma regulamentação estrita ou plano pré- 
estabelecido foi importante para as primeiras ações de proteção - basta lembrar que a primeira reserva implantada pela CAPRE com a licitação dos minicomputadores baseou-se em uma prerrogativa que lhe foi conferida para diminuir o déficit na balança comercial, não para implantação de uma política industrial. Posteriormente, a aprovação da Lei 7.232/84 pelo Congresso Nacional foi saudada como elemento de legitimação democrática da antiga política, criticada como autoritária na esteira da SEI. Por fim, esta mesma elevação ao status legal expôs abertamente as intenções do Estado brasileiro de proteger o setor de informática legal, permitindo que empresas estrangeiras e o departamento de comércio do governo norte-americano aprofundassem suas articulações para ataque à política.

Já a atual política instituída pela Lei 8.248/91 nasce em um contexto radicalmente diverso. O momento de formulação inicial é marcado por um amplo processo de reestruturação econômica, além da grave crise inflacionária e experiências mal-sucedidas de estabilização. Neste período, as idéias liberalizantes e o consenso de Washington ganharam grande força no país. As práticas protecionistas, das quais a antiga política de informática representou um grande exemplo, foram abandonadas. O modelo de política industrial adotado (PICE) tinha por meta a abertura do mercado brasileiro ao capital e produtos externos, bem como a modernização da estrutura industrial e comercial. Isso demandava uma nova configuração de atribuições para os setores público e privado, na qual, segundo a PICE, cabia ao Estado um papel mais neutro, de gerar e manter a estabilização no plano macroeconômico, e estabelecer um marco regulatório favorável aos negócios, amistoso ao capital externo e que colocasse regras claras ao funcionamento do mercado.

$\mathrm{O}$ acerto da nova política e sua adequação à nova realidade econômica e institucional do país puderam ser confirmados pela ampla adesão das empresas do setor a seus termos e condições, com a geração de crescentes volumes de recursos para P\&D, assim como pelo grande número de universidades e instituições de ensino e pesquisa cadastradas para convênios e recebimento desses valores. A política é justificada ainda por seus resultados positivos no combate ao mercado cinza. Os resultados da política (e parcialmente também a falta de propostas alternativas factíveis) fizeram com que os seus rumos e sua dinâmica evolutiva deixassem de ser influenciados pelo debate calcado em 
posições teóricas. Ao contrário, são as próprias questões internas e a disputa com a ZFM que passam a determinar a agenda do debate.

Considerando a formulação e adoção da atual política de informática, parece incorreto afirmar, ao menos neste caso, que a internacionalização da economia brasileira nos anos noventa e o abandono do protecionismo da década anterior possam ser identificados com uma perda completa de importância ou de espaço para uma política industrial ou atuação estatal para desenvolvimento setorial (um "eclipse do Estado", para utilizar uma alegoria de Evans ${ }^{1}$ ). Conforme o histórico traçado das duas políticas, seria mais acertado argumentar que seu papel foi substancialmente alterado em suas bases, ou seja, que esses fatores implicaram a utilização de medidas distintas - que no caso seriam as isenções fiscais, o PPB, as exigências de $\mathrm{P} \& \mathrm{D}$, os programas prioritários de informática, o financiamento público através do CT-INFO, e o poder de compra governamental. A nova estratégia pode ser lida como uma evolução com relação ao modelo anterior, na medida em que tenta conciliar as vantagens de um sistema de mercado ancorado internacionalmente, sem negligenciar os elementos dinâmicos e a importância do financiamento e intervenção pública para pesquisa e desenvolvimento tecnológico.

Neste período, a influência da estrutura jurídica sobre o progresso da política parece ter se dado principalmente através de três formas, que não são temporalmente apartadas e coincidem em diversos momentos. Em primeiro lugar, a regulação pouco específica da política no plano da lei permitiu a evolução de seu arcabouço normativo através da competência legislativa outorgada à burocracia ministerial. Isto é especialmente verdade no caso do PPB, conforme tentei descrever na seção 4.1 .

Ademais, nessa fase, questões de cunho quase exclusivamente jurídico alteraram profundamente os rumos da política. Este é o caso da Emenda Constitucional 6/95, que

\footnotetext{
${ }^{1}$ Em artigo de 1997, Evans toma como ponto de partida um trabalho de Nettl de 1968 para indagar sobre um possível "eclipse do Estado" devido à internacionalização econômica. O autor refuta a tese de que a nova lógica econômica leva inexoravelmente ao eclipse, atribuindo-o muito mais a elementos ideológicos e políticos, dentre os quais o principal seria a teoria neo-utilitarista analisada no primeiro capítulo. "If eclipse does occur, it will not be the inexorable result of any ironclad structural logic. The economic logic of globalization does not in itself dictate eclipse. While globalization does make it harder for states to exercise economic initiative, it also increases both the potential returns from effective state action and the costs of incompetence. Only when viewed through the peculiar prism of our current global ideological order does globalization logically entail movement toward statelessness." (EVAN, 1997, pp. 73-74, grifos nossos).
} 
acabou por afetar os incentivos inicialmente previstos na Lei de Informática, particularmente devido a uma interpretação do MCT que julgou haver inconstitucionalidade nesses casos (o Parecer CONJUR/MCT-ACF 231/95 - ver seção 3.5), e também da decisão do STF em 2000, que atacou a prorrogação da antiga lei através de medidas provisórias, afetando assim a sua renovação (seção 3.6). Finalmente, o fato de a legislação original ter estabelecido o seu prazo final de validade (sunset clause) também parece ter sido um importante elemento dinamizador, na medida em que possibilitou a discussão, alteração e inserção de algumas das novas regras e instrumentos (o CT-Info) no âmbito da política.

Concluída esta análise do direito enquanto elemento da evolução da política de informática, cumpre retomar como esta política se utilizou de ferramentas jurídicas dentro de determinadas racionalidades para atingir seus objetivos. Aqui acredito não haver nada acrescentar ao que já foi explicado no capítulo 4, em especial na tabela apresentada na seção 4.3, em que tento relacionar os instrumentos analisados. Conforme ali descrito, a política de informática parece melhor descrita como um conjunto articulado de ações ou instrumentos, cada qual fazendo um diferente uso do direito enquanto ferramenta, o que revela uma riqueza e complexidade da política de informática.

Nos três instrumentos de política pública analisados naquele capítulo, o direito cumpriu um papel instrumental, colaborando para a modificação de situações ou indicadores considerados problemáticos ou insuficientes. Procurei mostrar como este papel pode ser multifacetado, abrangendo (i) a distorção dos sistemas de preços de mercado afetando as estratégias empresariais (através dos incentivos fiscais e dos PPBs), (ii) a instituição de uma amarração institucional que financie e viabilize projetos de $P \& D$ empresarial, e ainda (iii) a instituição de uma fonte de financiamento pretensamente estável para o sistema nacional de C\&T e para projetos de inovação na área de TI.

Em relação à análise histórica desenvolvida ao longo do capítulo 4, também é preciso lembrar que o direito pode funcionar como problema, gargalo ou empecilho ao bom funcionamento dos instrumentos da política. No caso, isto ocorreu principalmente devido a uma "má calibragem" entre benefícios e custos instituídos - isenção físcal versus contrapartidas em P\&D; e também devido a lacunas ou falhas no ordenamento que 
permitem ao governo federal não utilizar os recursos do CT-Info conforme determina a lei que o instituiu (através da manobra do contingenciamento).

O último exercício pretendido para esta parte final para responder à pergunta formulada é tentar expor como passei a entender que a construção do mercado de informática no país foi em grande parte fruto da ação do Estado e da estrutura jurídica estabelecida por ele. Compreendo que se trata de uma afirmação em alguma medida controversa, e não tenciono com isso dizer que a economia é totalmente determinada ou construída pelo direito. Tenho ciência de que há outras forças de vital importância presentes, seja de mercado, política e mesmo a dinâmica tecnológica da indústria, e acredito ter dado a cada um desses fatores a sua devida importância ao longo da narrativa das políticas. Entretanto, no caso do mercado de informática brasileiro, seria difícil imaginar sua existência sem a presença do vetor estatal por meio de seus tentáculos jurídicos, conforme retomado abaixo.

Aqui, todavia, trata-se de um exercício abstrato de isolar ou dar maior preponderância ao componente da política pública e seu aspecto jurídico, tentando construir um esquema que permita visualizar a sua importância na criação e amadurecimento desse mercado. Para isso, retomarei mais uma vez minha narrativa histórica das políticas, mas em bases diferentes daquelas utilizadas anteriormente. Aqui, meu elemento de análise e critério divisor das fases ou momentos deixa de ser a evolução da própria política, tornando-se a tarefa a ser cumprida para a constituição e desenvolvimento da indústria, ou ainda o problema ou gargalo que era necessário superar. A partir desse centro, identifico qual a ferramenta estatal ou jurídica utilizada para solucionar a questão. 


\begin{tabular}{|c|c|c|c|}
\hline \multicolumn{4}{|c|}{ O Estado e o direito na construção do mercado de informática no Brasil } \\
\hline & $\begin{array}{l}\text { Função exercida pelo Estado e } \\
\text { direito/ Problema a ser superado }\end{array}$ & Período & Instrumentos aplicados \\
\hline $1^{\text {a }}$ fase & $\begin{array}{l}\text { Formação de recursos humanos } \\
\text { qualificados para o setor } \\
\text { Criação de primeiras instituições } \\
\text { aptas a lidar com a informática }\end{array}$ & $\begin{array}{l}\text { Período pré- } \\
\text { reserva de } \\
\text { mercado } \\
\text { (anos } 60- \\
1977 \text { ) }\end{array}$ & 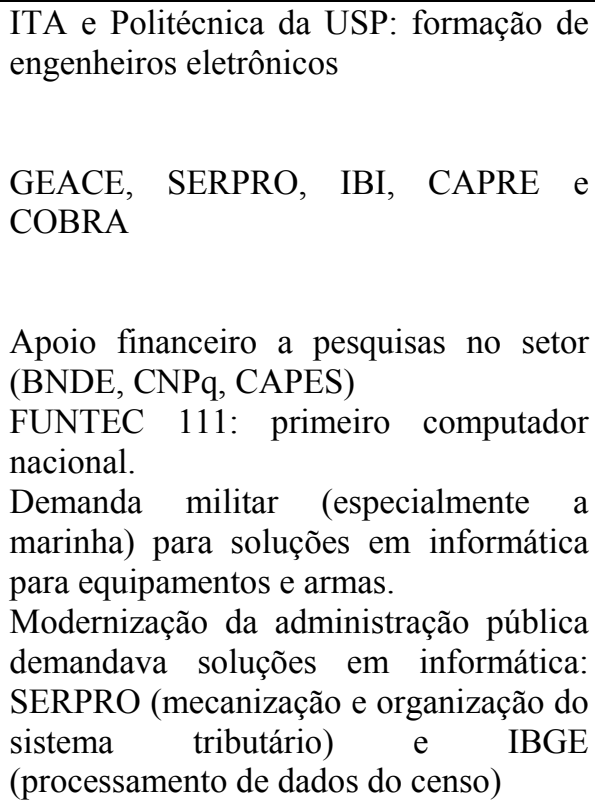 \\
\hline $2^{a}$ fase & $\begin{array}{l}\text { Geração de demanda por } \\
\text { equipamentos e produtos produzidos } \\
\text { localmente, impulsionando a oferta } \\
\text { (florescimento das empresas e } \\
\text { tecnologia nacional). }\end{array}$ & $1977-1991$ & $\begin{array}{l}\text { Reserva de mercado (estratégia de } \\
\text { estufa) para alguns segmentos, mantendo } \\
\text { o mercado interno como monopólio dos } \\
\text { produtores locais: } \\
\text { Licitação dos minis e superminis } \\
\text { Lei } 7.232 / 84\end{array}$ \\
\hline $3^{\text {a }}$ fase & $\begin{array}{l}\text { Instituição da plena concorrência no } \\
\text { setor, para elevar qualidade, nível e } \\
\text { diversidade dos equipamentos } \\
\text { ofertados; aumentar competitividade } \\
\text { dos agentes. }\end{array}$ & 1991 & $\begin{array}{llll}\text { Extinção da reserva e abertura da } \\
\text { economia à concorrência } \\
\text { equipamentos importados }\end{array}$ \\
\hline $4^{a}$ fase & $\begin{array}{l}\text { Evitar que a concorrência externa } \\
\text { exterminasse indústria nacional } \\
\text { Fomento a P\&D } \\
\text { Dispersão geográfica da indústria }\end{array}$ & $\begin{array}{l}1991 \text { - pre- } \\
\text { sente }\end{array}$ & $\begin{array}{l}\text { Lei de Informática: } \\
\text { PPB, dedução de IR para investimentos } \\
\text { em empresas de informática, } \\
\text { contrapartidas em P\&D. }\end{array}$ \\
\hline
\end{tabular}

A partir desta tabela é possível extrair principalmente duas conclusões. A primeira é a de que parece haver uma concatenação lógica na seqüência da atuação estatal. Assim, a conclusão de cada fase descrita constitui um requisito do desafio a ser enfrentado na etapa seguinte, bem como representa um esgotamento ou superação do momento anterior. Desta forma, a geração de demanda por produtos nacionais através da reserva de mercado só fazia sentido porque, na fase anterior, certas condições foram atendidas para a constituição de empresas que atenderiam essa demanda (formação de mão-de-obra qualificada e desenvolvimento e aquisição de conhecimento técnico através das pesquisas demandadas 
pelo poder público). Por outro lado, a reserva impedia a concorrência e inibia a introdução de inovações tecnológicas. Para elevar a competitividade e solucionar o desnível entre o mercado interno e o internacional foi realizada a abertura, permitindo a importação irrestrita de produtos. Finalmente, a concorrência externa ameaçava a viabilidade das empresas e produção nacional, sendo necessária a instituição da política pública de informática, com seus incentivos fiscais e obrigações do PPB e de P\&D.

Não pretendo afirmar que esta seqüência foi previamente planejada de forma inteiramente consciente, ou que havia uma racionalidade perfeita sobre como estruturar a atuação estatal para o desenvolvimento deste setor. $\mathrm{Na}$ verdade, não acredito que, em qualquer desses momentos, fosse possível saber de antemão os resultados a serem atingidos e quais seriam os desafios da etapa seguinte. Parece mais plausível crer que a própria dinâmica da constituição desse mercado tenha ditado a natureza da intervenção estatal em cada momento. Assim, na medida em que os problemas ou gargalos foram se apresentando, uma reposta correspondente foi adotada, trazendo consigo uma nova conjuntura.

A segunda e mais facilmente identificável conclusão é a de que Estado e o direito foram fundamentais em todas as etapas de construção desse mercado no Brasil. Como mencionei, a tabela procura isolar o componente da intervenção estatal nesse processo, mas a partir dos instrumentos utilizados para superação dos problemas e de seus resultados identificados nos capítulos prévios, parece bastante razoável afirmar que não se pode compreender a evolução do setor de informática no país sem levar em consideração o que o Estado e as políticas públicas implantadas fizeram para que esse setor pudesse se desenvolver.

Nesta conclusão tentei identificar três dimensões do papel do direito enquanto elemento integrante de uma política industrial: a sua influência na evolução da política, o seu papel instrumental enquanto ferramenta jurídica para as estratégias ou racionalidades de ação adotadas, e sua relevância na promoção e desenvolvimento do mercado. Estas parecem ser, ao final, as formas através das quais o arcabouço normativo se fez presente na política de informática brasileira ao longo dos anos, e de certa forma a procurada resposta à pergunta de como pode ser descrito o papel do direito no âmbito desta política setorial. 
Embora tenha tentado extrair uma conclusão geral das três análises realizadas, acredito ser difícil descrever uma lição desse tipo que fuja do óbvio reconhecimento da existência de uma relação estreita entre direito e política industrial, ou mesmo entre direito e desenvolvimento econômico. Conforme tentei expor ao início da dissertação, isto foi identificado já há algum tempo pela literatura de Law and Development. Volto assim a minha proposta de não chegar a conclusões no âmbito teórico ou abstrato, mas me manter no plano concreto do estudo de caso realizado. Ao final, parece-me mais adequado interpretar as contribuições deste trabalho como específicas, traduzindo-se na proposta explicativa do papel cumprido pelo direito nesta política pública, conforme a descrição realizada acima.

Cabe por fim um reconhecimento pessoal: o mote inicial que me levou a empreender a pesquisa - a renovação permanente dos incentivos temporários da Lei de Informática como indício de falhas na formulação e implementação da política - revelou-se parcialmente falso. Ao contrário, ao longo da pesquisa empreendida pareceu-me claro que foram exatamente seus resultados bem sucedidos e a dinâmica interna da própria política que levaram às duas renovações.

No entanto, também é importante mencionar que essas prorrogações carregam em si um elemento perverso - a expectativa de renovação contínua pode induzir o empresariado a adotar comportamentos oportunistas, não utilizando os incentivos desta política setorial para um fortalecimento através da inovação tecnológica, mas apenas como uma vantagem de competitividade momentânea, representados pelos preços reduzidos pelos benefícios fiscais. 


\section{REFERÊNCIAS BIBLIOGRÁFICAS}

ABINEE. Desempenho Setorial 2008. 2008. Disponível em $<$ http://www.abinee.org.br/ abinee/decon/decon15.htm>. Acesso em 22.6.2008.

ACEMOGLU, Daron; JOHNSON, Simon; ROBINSON, James. Institutions as the Fundamental Cause of Long-Run Growth. NBER Working Paper No. 10481, 2004. Disponível em <http://www.nber.org/papers/w10481>. Acesso em 16 jun. 2007.

ADLER, Emanuel. Ideological "Guerrillas" and the Quest for Technological Autonomy: Brazil's Domestic Computer Industry. International Organization. v. 40, n. 3. MIT Press. 1986, pp. 673-705.

ALCHIAN, A. A. Uncertainty, Evolution and Economic Theory. Journal of Political Economy. v. 58, 1950, pp. 211-222.

AQUINO, Miriam. O Poder de compra tem nova preferência: a tecnologia. Informática Hoje, n. 397, Dezembro 1995, p. 6.

. O Congresso acorda para a lei de informática. Informática Hoje, n. 477, Julho 1999, pp. 42-43. $56-57$.

. Como será o futuro fisscal da indústria. Informática Hoje, n. 517, Maio 2001, pp.

ARAÚJO, Veneziano de Castro. Métodos Quantitativos de Avaliação de

Transbordamentos de Conhecimento: Uma aplicação ao sistema local de tecnologia da informação e comunicação em Campinas. Dissertação de Mestrado em Engenharia apresentada à Escola Politécnica da Universidade de Mestrado. São Paulo, 2007.

ARROW, Kenneth J. Economic Welfare and the Allocation of Resources for Invention. In The Rate of Direction of Inventive Activity: Economic and Social Factors. Princeton: National Bureau of Economic Research, Princeton University Press, 1962.

ARVATE, Paulo Roberto; BIDERMAN, Ciro. Vantagens e desvantagens da intervenção do governo na economia. In MENDES, Marcos (Org.). Gasto Público Eficiente: 91 propostas para o desenvolvimento do Brasil. São Paulo: Instituto Fernand Braudel/Topbooks, 2006. 
BANCO MUNDIAL. Law and Development Movement. Disponível em $<$ http:// www1.worldbank.org/publicsector/legal/ldmovement.htm>. Acesso em 29 jun. 2007.

The East Asian Miracle: economic growth and public policy. New York: Oxford University Press, 1993.

BAPTISTA, Margarida. Políticas de estado e seus efeitos sobre a indústria brasileira de informática. Disponível em <http://www2.mre.gov.br/ipri/papers/cienciatecnologia/ artigo05.doc $>$. Acesso em 5.5.2006.

BASTOS, Celso Ribeiro. Comentários à Constituição do Brasil: promulgada em 5 de outubro de 1988. vol. 7. São Paulo: Saraiva, 1988.

BAUMANN, Renato. O Brasil nos anos 1990: uma economia em transição. In BAUMANN, Renato (Org.). Brasil: Uma década em transição. Rio de Janeiro: Campus. 1999, pp. 11-99.

BELLO, J. H.; HOLMER, A. F. U.S. Trade Law \& (and) Policy Series \#13: Unilateral Action to Open Foreign Markets: The Mechanics of Retaliation Exercises. The international Lawyer, 22, 1988.

BEMATECH. Resultados da Lei de Informática - Uma avaliação: Parte 1 - Impactos no segmento industrial automação de serviços. Brasília: I Seminário Resultados da Lei de Informática, 2003. Disponível em <http://www.mct.gov.br/index.php/content/ view/32266.html>. Acesso em 22 dez. 2008.

BIELSCHOWSKY, Ricardo (Org.). Cinqüenta anos de pensamento na CEPAL. v. 1 e 2. Tradução de Vera Ribeiro. Rio de Janeiro: Record, 2000.

BOTELHO, Antônio José Junqueira et. al. From Industry Protection to Industry Promotion: IT Policy in Brazil. Irvine: University of California, 1999. Disponível em $<$ http://www.crito.uci.edu/git/publications/pdf/brazil-case-10-99.pdf $>$. Acesso em 19 dez. 2008.

. TIGRE, Paulo Bastos. Perspectivas de Cooperação Brasil - Argentina nas

Tecnologias da Informação. Seminário Brasil - Argentina. Rio de Janeiro, 1999.

BLANCHARD, Olivier. Macroeconomia. Tradução de Claudia Martins Monica Rosemberg. 4 ed. São Paulo: Pearson Prentice Hall, 2007. 
BRESSER PEREIRA, Luis Carlos. Desenvolvimento e crise no Brasil: história, economia e política de Getúlio Vargas a Lula. São Paulo: Editora 34. 2003.

BURLAMAQUI, Leonardo. Evolutionary Economics and the economic role of the state. In: CHANG, Ha-Joon; BURLAMAQUI, Leonardo; CASTRO, Ana Célia (Org.).

Institutions and the role of the state. Massachusetts: Edward Elgar Publishing, 2000.

CAMPANÁRIO, Milton de Abreu; SILVA, Marcello Muniz; COSTA, Tiago Ribeiro. Política Industrial, Teconlógica e de Comércio Exterior (PITCE): análise de fundamentos e arranjos institucionais. XI Seminário Latino-Iberoamericano de Gestión Tecnológica. Salvador, 2005.

. A Teoria da Mudança Técnica: Inovação tecnológica e ciclos econômicos no modelo de Schumpeter. Versão Preliminar. S.1.: s.n., s.d.

CAMPOS, Roberto. Férias coletivas à razão. 1999. Disponível em $<$ http:// pensadoresbrasileiros.home.comcast.net/ pensadoresbrasileiros/RobertoCampos/ferias_col etivas_a_razao.htm>. Acesso em 7 mar. 2008.

CAMPOS, Rui. A guerrilha dos chips. Exame Informática. Abril 1991, n. 4, p. 30.

CAROTHERS, Thomas. Promoting the Rule of Law Abroad: The search of Knowledge. Washington D.C.: Carnegie Endowment for International Peace, 2006.

CASA CIVIL DA PRESIDÊNCIA DA REPÚBLICA et. al. Diretrizes de Política Industrial, Tecnológica e de Comércio Exterior. Brasília, 2003.

CASSIOLATO, José E.; BAPTISTA, Margarida A. C. The effects of the Brazilian liberalisation of the IT industry on technological capabilities of local firms. Information Technology for Development. Outubro 1996; v.7, n. 2

CHANG, Ha-Joon. The Political Economy of Industrial Policy. New York: St. Martin's Press, 1996.

. An institutionalist perspective on the role of the state: towards an institutionalist political economy. In: CHANG, Ha-Joon; BURLAMAQUI, Leonardo; CASTRO, Ana Célia (Org.). Institutions and the role of the state. Massachusetts: Edward Elgar Publishing, 2000.

Chutando a escada: a estratégia do desenvolvimento em perspectiva histórica. Tradução de Luiz Antônio Oliveira de Araújo. São Paulo: UNESP. 2004. 
; EVANS, Peter B. The role of Institutions in Economic Change. First draft, 1999. Disponível em <http://www.econ.cam.ac.uk/faculty/chang/c\&e-pdf.pdf $>$. Acesso em 16 jun. 2007.

COGGIOLA, Osvaldo; OLIVEIRA, Marinalva de; PAIVA, Jacob. O veto à regulamentação do Fundo Nacional de Desenvolvimento Científico e Tecnológico FNDCT e os Fundos Setoriais - FS. Brasília: Sindicato Nacional dos Docentes das Instituições de Ensino Superior, 2006. Disponível em <http://www.andes.org.br/Circ14906.pdf>. Acesso em 20 dez. 2008.

CONCEIÇÃO, Maria. Uma luta desigual. Dados \& Idéias, n. 3, Dezembro/Janeiro 197677, pp. 16-20.

CORREA, Carlos Maria. EI derecho informático en América Latina. In Informática y derecho: aportes de doctrina internacional. v. 2. Buenos Aires: Depalma. 1996.

CRUZ, Hélio Nogueira da. Observações sobre a mudança tecnológica em Schumpeter. Revista Estudos Econômicos, v. 18, n. 3, Setembro/Outubro 1988.

DADOS \& IDÉIAS, n. 4, Fevereiro/Março 1976, p. 21.

DALLARI BUCCI, Maria Paula. Direito Administrativo e Políticas Públicas. São Paulo: Saraiva, 2002.

DAM, Kenneth W. The Law-Growth Nexus: The Rule of Law and Economic Development. Washington D.C.: Brookings Institution Press, 2006.

DANTAS, Marcos. O crime de Prometeu: como o Brasil obteve a tecnologia da informática. Rio de Janeiro: Abicomp. 1989.

DANTAS, Vera. A guerrilha tecnológica: a verdadeira história da política nacional de informática. Rio de Janeiro: LTC-Livros Técnicos e Científicos. 1988.

DELL BRASIL. Os resultados obtidos pela Dell Computadores do Brasil na utilização dos recursos da lei de informática. Brasília: I Seminário Resultados da Lei de Informática, 2003. Disponível em <http://www.mct.gov.br/index.php/content/view/ 32266.html>. Acesso em 22 dez. 2008. 
DIÁRIO do Congresso Nacional. Debates parlamentares em diferentes datas citados ao longo do texto.

ERICSSON TELECOMUNICAÇÕES S.A. Resultados dos investimentos em pesquisa e desenvolvimento. Brasília: I Seminário Resultados da Lei de Informática, 2003.

Disponível em $<$ http://www.mct.gov.br/index.php/content/view/ 32266.html $>$. Acesso em 22 dez. 2008.

EVANS, Peter B. Multinationals, State-Owned Corporations, and the Transformation of Imperialism: A Brazilian Case Study. Economic Development and Cultural Change, v. 26, n. 1, Outubro 1977, pp. 43-64.

State, Capital and the Transformation of Dependence: the Brazilian Computer Case. World Development, v. 14. n. 7. 1986, pp. 791-808.

Declining Hegemony and Assertive Industrialization: U.S.-Brazil Conflicts in the Computer Industry. International Organization, v. 43, n. 2, 1989, pp. 207-238.

; TIGRE, Paulo Bastos. Going Beyond Clones in Brazil and Korea: A Comparative Analysis of NIC Strategies in the Computer Industry. World Development, v. 17, n. 11, 1989, pp. 1751-1768.

. O Estado como Problema e Solução. Revista Lua Nova, n. 28/29. são Paulo:

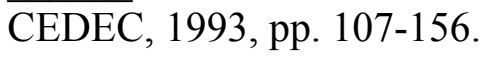

. The Eclipse of the State? Reflections on Stateness in an Era of Globalization. World Politics, v. 50, n. 1, Outubro 1997.

Autonomia e Parceria: Estados e transformação industrial. Tradução de Christina Bastos Tigre. Rio de Janeiro: UFRJ, 2004.

FARIA, José Eduardo. O Direito na economia globalizada. São Paulo: Malheiros. 1999.

FRANKEN, T. Um desconcertante mal-entendido ou dez anos de esforço tecnológico nacional postos em cheque. Dados \& Idéias, Agosto/setembro 1976, pp. 3-9.

O FIM da reserva chega mais cedo. Exame Informática, n. 5, maio 1992, pp. 64-66.

FUNDOS setoriais de C\&T escapam de contingenciamento. Protec: Pró-Inovação Tecnológica. Disponível em $<$ http://www.protec.org.br/noticias.asp?cod=2089>. Acesso em 10 jan. 2009. 
GARCIA, Renato; ROSELINO, José Eduardo. Uma avaliação da Lei de Informática e de seus resultados como instrumento indutor de desenvolvimento tecnológico e industrial. Campinas. 2004. Disponível em: <http://www.scielo.br/pdf/gp/v11n2/ a04v11n2.pdf $>$. Acesso em 20 jun. 2008.

GRAU, Eros Roberto. Lei de informática - economia concertada: liberação de bens para importação. Revista de Direito Mercantil, Industrial, Econômico e Financeiro. São Paulo: Revista dos Tribunais, n. 80.

O GUARDA-CHUVA se fecha. Exame Informática, 3 Outubro 1990, n. 10, pp. 4-6.

GUTIERREZ, Regina Maria Vinhais; e ALEXANDRE, Patrícia Vieira Machado. Complexo eletrônico brasileiro e competitividade. BNDES Setorial. Rio de Janeiro, n. 18, Setembro 2003, p. 165-192.

HELENA, Silvia. Minis: a decisão final. Dados \& Idéias. n. 2, Outubro/Novembro 1977 , pp. 34-45.

. A indústria de computadores: evolução das decisões governamentais. Revista de Administração Pública. n. 1. Outubro/Novembro 1980.

Rastro de Cobra. s.1.: s.n., 1984.

HP BRASIL. Impactos da Lei de Informática no estímulo à realização de $\mathbf{P} \& D$ em empresas. Brasília: I Seminário Resultados da Lei de Informática, 2003. Disponível em $<$ http:// www.mct.gov.br/index.php/content/view/32266.html >. Acesso em 22 dez. 2008.

HUNT, E. K. História do Pensamento Econômico: uma perspectiva crítica. Tradução de José Ricardo Brandão Azevedo e Maria José Cyhlar Monteiro. 2. ed. Rio de Janeiro: Elsevier, 2005.

INSTITUTO DE ESTUDOS PARA DESENVOLVIMENTO INDUSTRIAL (IEDI). Carta IEDI n. 161: Os Fundos Setoriais de C\&T: Desafios e Perspectivas para 2005. 2005. Disponível em <http://www.iedi.org.br/cgi/cgilua.exe/sys/ start.htm?infoid=1293\&sid=20\&tpl=printerview $>$. Acesso em 12 dez. 2008.

IBM Brasil. Atividades de Pesquisa e Desenvolvimento da IBM no Brasil durante a vigência da Lei 8248/91. Brasília: I Seminário Resultados da Lei de Informática, 2003. Disponível em $<$ http:// www.mct.gov.br/index.php/content/view/32266.html $>$. Acesso em 22 dez. 2008. 
ISENÇÃO de IPI só para quem montar placa. Informática Hoje, n. 331, 29 Março 1993, p. 24.

ITAUTECH PHILCO. Resultados da Lei de Informática - Uma avaliação: Parte 1 Impactos no segmento industrial automação de serviços. Brasília: I Seminário Resultados da Lei de Informática, 2003. Disponível em <http://www.mct.gov.br/index.php/content/ view/32266.html>. Acesso em 22 dez. 2008.

JOHNSON, Chalmers. The industrial policy debate. São Francisco: Institute for Contemporary Studies, 1984.

JORGENSON, Dale. Information Technology and the U.S. Economy. Harvard Institute of Economic Research, 2001. Disponível em <http://papers.ssrn.com/ paper.taf?abstract_id $=257536>$. Acesso em 9 nov. 2008.

; STIROH, Kevin J. Information Technology and growth. The American Economic Review, v. 89, n. 2, Papers and Proceedings of the One Hundred Eleventh Annual Meeting of the American Economic Association, Maio 1999.

KIM, Linsu; NELSON, Richard R. (org.). Tecnologia, aprendizado e Inovação: as experiências das economias de industrialização recente. Tradução de Carlos D. Szlak. Campinas: Unicamp, 2005.

LEI de Informática: a indústria por um fio. Informática Hoje, n. 509, dezembro 2000, pp. 16-17.

A LEI de informática, enfim, sai do papel. Informática Hoje, n. 531, dezembro 2001, p. 4.

MARQUES, Ivan da Costa. Reserva de Mercado: um mal entendido caso políticotecnológico de "sucesso" democrático e "fracasso" autoritário. Economia, Curitiba, n. 24, 2000 .

MARX, Karl; ENGELS, Friederich. Manifesto do Partido Comunista. Tradução de Sueli Tomazzini Barros Cassal. Porto Alegre: L\&PM, 2002.

MELO, Paulo Roberto de Souza. Complexo Eletrônico: Diagnósticos e Perspectivas. BNDES Setorial, Rio de Janeiro, n. 10, Setembro 1999, p. 269-284. 
MERCURO, Nicholas; MEDEMA, Steven G. Economis and the Law: from Posner to Post-Modernism. Princeton: Princeton University Press, 1997.

MINISTÉRIO DA CIÊNCIA E TECNOLOGIA (MCT). Ciência, Tecnologia e Inovação para o Desenvolvimento nacional: balanço das ações do MCT: 2003-2006. Seminário Fundos, 2006. Disponível em <http://www.inpe.br/dspace/bitstream/123456789/217/1/CT-Inovacao_Balanco_MCT.pdf $>$. Acesso em 2 jan. 2009.

Regulamentação da Lei $n^{0}$ 11.077, de 30.12.2004. Brasília, 2005. Disponível em < http://www.certi.org.br/labelectron/Hardwarebr/MCT/ApresentaLei11077(25maio).pdf $>$. Acesso em 24 dez. 2008.

MINISTÉRIO DO PLANEJAMENTO, ORÇAMENTO E GESTÃO (MPOG). Plano Plurianual 2004-2007: Orientação Estratégica de Governo Um Brasil Para Todos: Crescimento Sustentável, Emprego e Inclusão Social. s.l.: s.n., s.d. Disponível em $<$ http://www.defesanet.com.br/docs/ppa_2004_2007.pdf $>$. Acesso em 8 jan. 2009.

NASSIF, André. Uma contribuição ao Debate sobre a nova política industrial brasileira. Textos para Discussão 101 do BNDES. Rio de Janeiro: BNDES, 2003.

O complexo eletrônico brasileiro. 2002. Disponível em $<\mathrm{http}: / /$

www.bndes.gov.br/conhecimento/livro_setorial/setorial08.pdf>. Acesso em 20 jun. 2008.

NASSIF, Luís. O faroeste na lei de informática. Folha de São Paulo, 7 Abr. 2003.

NEGRI, João Alberto de; NEGRI, Fernanda de; LEMOS, Mauro Borges. Capítulo 7: Impacto do programa FNDCT sobre o desempenho e o esforço tecnológico das empresas industriais brasileiras. In IPEA. Políticas de Incentivo à inovação tecnológica no Brasil. IPEA, 2008.

; SALERNO, Mario Sergio; CASTRO, Antonio Barros de. Inovações, padrões tecnológicos e desempenho das firmas industriais brasileiras. In: NEGRI, João Alberto; SALERNO, Fernanda de (Org.). Inovações, padrões tecnológicos e desempenho das firmas industriais brasileiras. Brasília: IPEA, 2005, p. 5-46.

NELSON, Richard R.; WINTER, Sidney G. Neoclassical vs. Evolutionary Theories of economic growth: critique and prospectus. The economic Journal, Dezembro 1974, pp. 896-905.

Uma teoria evolucionária da mudança econômica. Tradução de Cláudia Heller. Campinas: UNICAMP, 2005. 
NORTH, Douglas. Institutions, Institutional change and economic performance. New York: Cambridge University Press, 1990.

NOVAS cores na Informática. Dados e Idéias. Janeiro de 1990, pp. 18-21.

Organização para Cooperação e Desenvolvimento Econômico (OCDE). OECD Information Technology Outlook 2000: ICTs, E-Commerce and the Information Economy. OECD Publishing, 2000. Disponível em $<$ http://www.oecd.org/dataoecd/ 30/56/1939833.pdf $>$. Acesso em 8. jan. 2009.

OECD Information Technology Outlook 2002: ICTs and the Information Economy. OECD Publishing, 2002. Disponível em $<$ http://www.oecd.org/dataoecd/ 63/60/1933354.pdf $>$. Acesso em 8 jan. 2009.

OECD Communications Outlook 2003: Information and Communications Technology. OECD Publisching, 2003. Disponível em $<$ http://kampanya.org.tr/telekom/ belge/oecdcommunicationsoutlook2003.pdf. Acesso em 8 jan. 2009.

OECD Information Technology Outlook 2004. OECD Publishing, 2004.

Disponível em < http://www.oecd.org/dataoecd/22/18/37620123.pdf $>$. Acesso em 19 dez. 2008 .

OECD Science, Technology and Industry Outlook 2006. OECD Publishing, 2006. Disponível em <http://www.sourceoecd.org/industrytrade/926402848X > . Acesso em 2 jun. 2007.

PACK, Howard. Is there a case for industrial policy? A critical survey. The World Bank Research Observer, v. 21, n.2, 2006, pp. 267-297.

PEREIRA, Newton Müller. Fundos Setoriais: Avaliação das estratégias de implementação e gestão. Textos para discussão 1136. Brasília: IPEA, 2005.

PEREZ, Carlota; SOETE, Luc. Catching up in technology: entry barriers and windows of opportunity. In DOSI, Giovanni et. al. (eds.). Technical Change and Economic Theory. London: Pinter Publishers, 1988, pp. 458-479.

PIRAGIBE, Clélia. Indústria da Informática: desenvolvimento brasileiro e mundial. Rio de Janeiro: Campos. 1985. 
ROCHA, Carlos. A hora dos mais ágeis. Exame Informática. Julho 1990, n. 7, p. 58.

RODRIK, Dani. Industrial Policy for the Twenty-First Century. Harvard University, 2004. Disponível em < http://ksghome.harvard.edu/ drodrik/unidosep.pdf $>$. Acesso em 19 $\operatorname{dez} 2008$.

ROSENBERG, Nathan. Por dentro da caixa-preta: tecnologia e economia. Tradução de José Emilio Maiorino. Campinas: Unicamp, 2006.

SALERNO, Mario Sergio; KUBOTA, Luis Claudio. Capítulo 1: Estado e Inovação. In IPEA. Políticas de Incentivo à inovação tecnológica no Brasil. Brasília: IPEA, 2008.

SANTOS, Rogério Santanna dos. Internet para todos, esse é o desafio do Brasil. In Mariana Balboni (ed.). Pesquisa sobre o uso das Tecnologias da Informação e da Comunicação no Brasil: TIC Domicílios e TIC Empresas 2006. São Paulo: Comitê Gestor da Internet no Brasil, 2007.

SCHUMPETER, Joseph A. Teoria do Desenvolvimento Econômico: Uma pesquisa sobre lucros, capital, crédito, juros e ciclo econômico. Rio de Janeiro: Fundo de Cultura, 1961.

Books, 1942.

Capitalism, Socialism and Democracy. 3. ed. New York: Harper and Colophon

Business Cycles: A Theoretical, Historical and Statistical Analysis of the

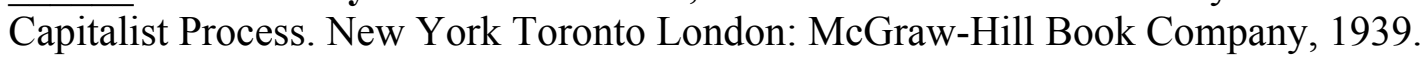

SECRETARIA ESPECIAL DE INFORMÁTICA (SEI). Boletim Informativo. Brasília. v. 1. n. 2. 1980.

SECRETARIA DE POLÍTICA DE INFORMÁTICA (SEPIN). Setor de Tecnologias da Informação: Resultados da Lei no. 8.248/91. Brasília: SEPIN, 1998.

; Ministério da Ciência e Tecnologia (MCT). Resultados da Lei de Informática Uma Avaliação: apresentação. Brasília: I Seminário Resultados da Lei de Informática, 2004. Disponível em <http://www.mct.gov.br/index.php/content/view/9931.html>. Acesso em 12.7.2006.

; Ministério da Ciência e Tecnologia (MCT). A lei de Informática e o estímulo a investimentos em Pesquisa, Desenvolvimento e Produção: uma avaliação necessária. 
Brasília: I Seminário Resultados da Lei de Informática, 2003. Disponível em $<$ http:// www.mct.gov.br/index.php/content/view/33541.html>. Acesso em 12 dez. 2008.

. Relatório preliminar de Resultados da Lei de Informática - ano base 2007. Brasília, 2008. Disponível em <http://www.mct.gov.br/index.php/content/view/ 75972.html>. Acesso em 1 jan. 2009.

SMITH, Adam. Uma investigação sobre a natureza e as causas da riqueza das nações. Lisboa: Calouste, 1980.

SOLOW, Robert. Technical change and the aggregate production function. Review of Economics and Statistics, 1957, pp. 312-320.

SOUZA NETO, Fábio. A chave está na competição. Exame Informática. Agosto 1990, n. 8, p. 34 .

STIGLITZ, Joseph E. Some Lessons from the East Asian Miracle. The World Bank Research Observer, v. 11, n. 2. Agosto 1996, pp. 151-77.

SUZIGAN, Wilson; VILLELA, Annibal V. Industrial policy in Brazil. Campinas: UNICAMP: 1997. FURTADO, João. Política Industrial e Desenvolvimento. Revista de Economia Política. v. 26, n. 2. São Paulo, Abril/Junho 2006.

; VERSIANI, Flávio R. O Processo brasileiro de industrialização: uma visão geral. X Congresso Internacional de História Econômica. Louvain, 1990.

TAPIA, Jorge Rubem Biton. A trajetória da política de informática brasileira (19771971): atores, instituições e estratégias. Campinas: Universidade de Campinas. 1995.

TAPSCOTT, Don; CASTON, Art. Paradigm shift: the new promise of information technology. McGraw-Hill. 1993.

TAVARES, Walkyria M. Leitão. A indústria eletrônica no Brasil e seu impacto sobre a balança comercial. Brasília: Câmara dos Deputados, 2001.

TIGRE, Paulo Bastos. Indústria brasileira de computadores: perspectivas até os anos 90. Rio de Janeiro: IPEA. 1987, p. 14. 
TRIPLETT, Jack. The Solow productivity paradox: what do computers do to productivity? The Canadian Journal of Economics/Revue canadienne d'Economique, v. 32, n. 2, Special Issue on Service Sector Productivity and the Productivity Paradox, Abril 1999.

TRUBEK, David M. Toward a Social Theory of Law: An essay on the study of Law and Development. The Yale Law Journal. v.82, n. 1, Novembro 1972.

; Galanter, Mark. Law and Society: Scholars in self-estrangement: some reflections on the crisis in Law and Development studies in the United States. Wisconsin Law Review, v. 1974: 1062, n. 4.

. Protectionism and Development: Time for a new Dialogue? International Law and Politics, v. 25: 345, 1993, pp. 345-366.

. The "Rule of Law" in Development Assistance: Past, Present and Future. Madison: University of Wisconsin, 2003. Disponível em: $<$ http://dev.law.wisc.edu// facstaff/trubek/RuleofLaw.htm>. Acesso em 22 dez. 2008.

UFRGS. A Universidade Federal do Rio Grande do Sul e Lei de Informática: A experiência da UFCG. Brasília: I Seminário Resultados da Lei de Informática, 2003. Disponível em $<$ http://www.mct.gov.br/index.php/content/view/32266.html $>$. Acesso em 22 dez. 2008.

UNICAMP. Resultados dos incentivos da Lei de Informática na UNICAMP. Brasília: I Seminário Resultados da Lei de Informática, 2003. Disponível em $<$ http:// www.mct.gov.br/index.php/content/view/32266.html>. Acesso em 22 dez. 2008.

WADE, Robert. Governing the Market: Economic Theory and the Role of Government in East Asian Industrialization. Princeton: Princeton University Press, 1990.

WEBSTER, Rosa. Micros: o fim do ano traz o otimismo de volta. Informática Hoje, n. 486, Dezembro 1999, p. 18.

WILLIAMSON, John. What Washington means by policy reform. In: WILLIAMSON, John (ed.). Latin American Adjustment: How much has happened? Washington: Peterson Institute for International Economics, 1990. 